\title{
REGIONALIZAÇÃO DA ASSISTÊNCIA À SAÚDE: ANÁLISE DE DEMANDA AO SERVIÇO DE URGÊNCIA/EMERGÊNCIA DE UM HOSPITAL UNIVERSITÁRIO
}

Heloisa Wey Berti Mendes

Tese de doutorado apresentada ao Departamento de Prática em Saúde Pública da Faculdade de Saíde Priblica da Universidade de São Paulo para obtenção do Grau de Doutor.

Área de Concentração: Serviços de Saúde Pública.

ORIENTADOR: PROF. DR. EURIVALDO SAMPAIO DE ALMEIDA

São Paulo

2003 


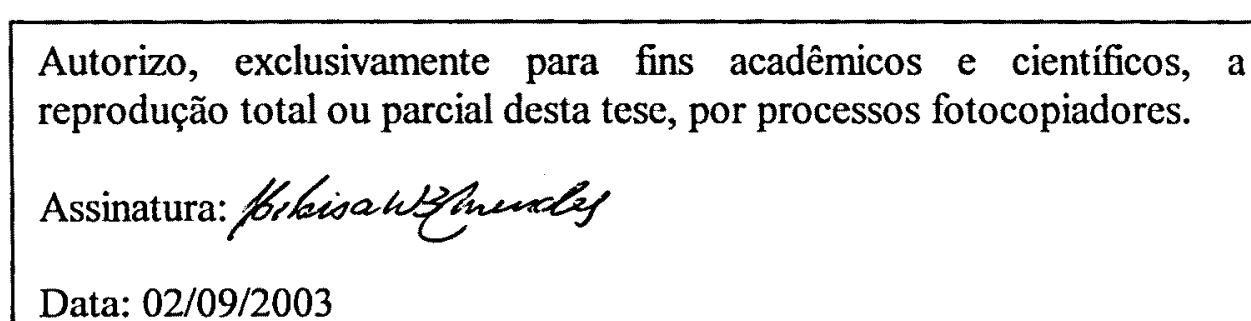

Data: 02/09/2003 
Aos usuários do Sistema Único de Saúde Aos profissionais de saúde 
Ao Professor Doutor Eurivaldo Sampaio de Almeida, etermamente grata por sua amizade, dedicação e liberdade para o desenvolvimento deste trabalho. 
Aos meus familiares e amigos que estiveram ao meu lado mesmo nos tempos da delicadeza 
A realizafão desta tese foi possível graças à colaborafão direta ou indireta de várias pessoas. $\mathcal{A}$ clas minfia gratidão:

Ao Professor Doutor Eurivaldo Sampaio de Almeida pela orientafão de todo o trabalfo.

Ao Professor Doutor Fernando Lefevre pela atenção e seriedade na orientação sobre a abordagem metodológica qualitativa.

Ao Professor Doutor Antonio Luiz Caldas Júnior do Departamento de Saúde Pú6lica da Faculdade de Medicina de Botucatu - UNESSP pelo incentivo dado à escolfa do tema deste estudo.

À Professora Doutora Cristina M.G.L.Parada, chefe do Departamento de Enfermagem da Faculdade de Medicina de Botucatu - UNEST, pela competência e generosidade a mim dedicadas na revisão do texto.

Aos colegas e funcionários do Departamento de Enfermagem da Faculdade de Medicina de Botucatu - VIFSP pelo apoio e companfeirismo.

Ao Agnaldo Rodrigues dos Santos, pela ajuda oferecida na solucão de problemas como computador.

À Bibliotecária do Campus da UNESP de Botucatu, Rosemary Cristina da Silva, pela revisão das referências 6ibliográficas. 
À Margareth Suely Peraçoli e à Maria do Carmo Medeiros, funcionárias do Departamento de Prática de Saúde Pú6lica da Faculdade de Saúde Pública - USP, pela atenção que me dispensaram.

Ao Professor Doutor Ricardo Cordeiro, do Departamento de Saúde Tública da Faculdade de Medicina de Botucatu - VNESP, pelas sugestões à amostragem .

À Professora Doutora Lídia Raquel de Carvalho, do Departamento de Estatística do Instituto de Biociências de Botucatu - UNAESP, pela colaboração na análise estatística.

À Assistente Social Senfora Maria Luiza Neris Luiz Caldas, do Departamento de Saúde Pública da Faculdade de Medicina de Botucatu - UNESP, pela colaboração nas entrevistas com os pacientes do Serviço de Urgência/Emergência e pela classificação das ocupações dos entrevistados.

À Denise Cristina dos Santos, Gabriela Cavalferi Tïburcio e Simone Aparecida dos Santos Brochado pela ajuda nas entrevistas com os pacientes do Servifo de Urgência /Emergência.

À Senfora Eliana Lovizuto Iessi, funcionária do Departamento de Saúde Pú6lica da Faculdade de Medicina de Botucatu - UNESP, pela codificafão dos diagnósticos.

Ao Doutor Emilio Curcelli, Médico Chefe do Servifo de Vrgência/Emergência, do Hospital das Clínicas da Faculdade de Medicina de Botucatu - UNAESP, pelo apoio e disponibilidade dedicados a este estudo.

À Senfiora Fátima Padovani, Diretora da DIRXI, pelo interesse e atenção dispensados. 
À Senfiora Patricia Maria Moratell, Diretora da Divisão de Planejamento da DIR XI, pelas informafões gentilmente disponibilizadas.

Aos médicos do Serviço de Vrgência/Emergência do Jospitaldas Clinicas da Faculdade de Medicina de Botucatu - UNEESR pelo interesse e colaboração direta com este estudo.

Aos médicos e funcionária da Central de Regulą̧ão Médica de Botucatu pela atençãoe presteza das informações.

Aos gestores municipais de saúde da DIRXI pelo acolfimento a mim dispensado.

Aos pacientes do Serviço de Vrgência/Emergência do Jospitaldas Clínicas da Faculdade de Medicina de Botucatu - UNEESP que tornaram possivel este trabalfo. 


\section{Resumo}

Objetivos. Identificação de barreiras ao processo de regionalização das ações e serviços de saúde na DIR XI, tendo como referência a atenção em urgência/emergência prestada pelo hospital universitário situado nessa regional. Método. A partir de análise quantitativa da demanda ao Serviço de Urgência/Emergência do hospital universitário, mediante dados coletados em entrevistas com 410 doentes que procuraram esse serviço e questionários aplicados aos médicos que os atenderam, procedeu-se a entrevistas com gestor regional, gestores municipais, médicos da Central de Regulação Médica e chefia do Serviço de Urgência/Emergência do hospital universitário. Esses depoimentos foram analisados utilizando-se a estratégia metodológica do Discurso do Sujeito Coletivo. Resultados. No Serviço de Urgência/Emergência apurou-se elevado percentual de doentes com alto grau de dependência do Sistema Único de Saúde, cujos problemas poderiam ser equacionados em Unidades Básicas de Saúde e/ou Hospitais Secundários. Foram identificadas deficiências da atenção básica e distorções nos sistemas de saúde regional e locais, provocando um movimento de demanda em direção inversa à hierarquização dos níveis de atenção. Gestores manifestaram preocupação em assegurar o acesso universal aos diversos níveis de assistência à saúde, apontaram necessidades de alterações na sistemática de atendimento das Unidades Básicas e revelaram interesse por mudanças na filosofia da atenção à saúde, identificando o modelo de promoção da saúde como mais satisfatório para a população. Conclusão. Devem ser potencializados os esforços para a organização dos sistemas locais e regional, mediante articulação entre todos os atores envolvidos, para o desenvolvimento de um sistema integrado que objetive a produção social da saúde.

Descritores: Urgência. Hospital Universitário. Assistência à saúde. Regionalização. 


\section{SUMMARY}

Objective. Identification of barriers to the regionalization process of health services and actions at the DIR XI, having as reference the urgency/emergency assistance afforded by the university hospital located in this regional. Method. Based on the demand quantitative analysis for Urgency/Emergency Service in the university hospital, data from interviews with 410 patients who searched for this service as well as questionnaire applied to the physicians who took care of them, interviews were carried out with regional and municipal coordinators, physicians of the Medical Regulation Center and Heading of Urgency/Emergency Service of the university hospital. These reports were analyzed through the methodological strategy of the Collective Subject Speech. Results. A high percentage of patients in the Urgency/Emergency service has been found having a great dependence level of the SUS - Unified Health System, whose problems could be solved in Basic Health Unities and/or Secondary Hospitals. Basic attention deficiency and local and regional health system distortion have been identified leading to a demand moving contrary to the attention level hierarchy. Managers have shown concern with the universal access to be assured to all levels of health assistance, pointed out the needs for changes in the attendance proceedings of Basic Unities and presented interest on health attention policy modifications. The health promotion model has been identified as the most suitable for the population. Conclusion. Efforts should be focused on local and regional system organization, through participation of all actors involved in order to develop a united system with the aim of social production of health.

Key-words: Urgency. University Hospital. Health Assistance. Regionalization. 


\section{Índice}

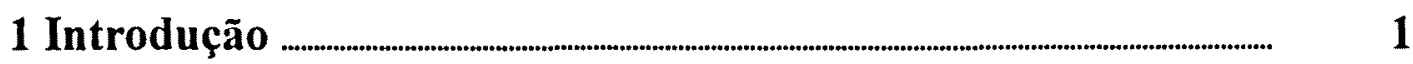

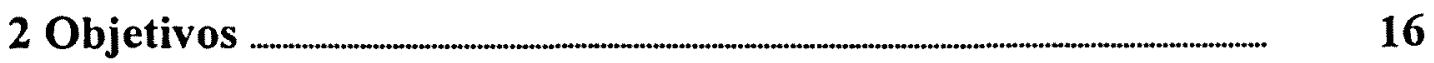

3 Método

3.1 Caracterização do cenário do estudo …_.......................... 17

3.2 Procedimentos metodológicos ………............ 29

4 Resultados e Discussão

4.1 Central de Regulação Médica …........................................ 35

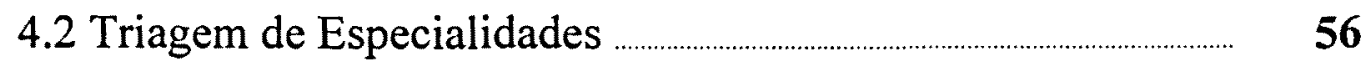

4.3 Razões e motivos para a busca do atendimento no Serviço de Urgência/Emergência do HC-FMB-UNESP ............................ $\quad 65$

4.4 Informações do atendimento médico …….......................... 98

$4.5 \mathrm{O}$ atendimento aos preceitos do SUS na perspectiva dos gestores

4.6 Conclusões dos gestores sobre a atenção à saúde prestada nos municípios

4.7 Sugestões dos gestores para fortalecer e ampliar as responsabilidades dos municípios na atenção básica de saúde

5 Considerações finais

\section{Anexos}




\section{LISTA DE TABELAS}

Tabela 1 - Distribuição das solicitações à Central de Regulação Médica da DIR XI - Botucatu, segundo município solicitante e justificativas de solicitação, no período de 01/03/2002 a 31/03/2002

Tabela 2 - Distribuição das solicitações à Central de Regulação Médica da DIR XI - Botucatu, segundo município solicitante e recurso solicitado, no período de 01/03/2002 a 31/03/2002

Tabela 3 - Distribuição de freqüências absolutas e relativas dos atendimentos feitos na Triagem de Especialidades do $\mathrm{HC}$ - FMB, segundo municípios da DIR IX, Botucatu, março de 2002

Tabela 4 - Distribuição de freqüências absolutas e relativas na amostra de pacientes entrevistados no Serviço de Urgência/Emergência do HC - FMB, segundo a escolaridade, Botucatu, março de 2002.

Tabela 5 - Distribuição de freqüências absolutas e relativas na amostra de pacientes entrevistados no Serviço de Urgência/Emergência do HC - FMB, segundo a faixa etária e o local de atendimento, Botucatu, março de 2002

Tabela 6 - Distribuição de freqüências absolutas e relativas na amostra de pacientes entrevistados no Serviço de Urgência/Emergência do HC - FMB, segundo município de procedência, classificado de acordo com o Plano Diretor de Regionalização, e o local de atendimento, Botucatu, março de 2002 
Tabela 7 - Distribuição de freqüências absolutas e relativas na amostra de pacientes entrevistados no Serviço de Urgência/Emergência do $\mathrm{HC}$ - FMB, segundo a faixa etária e a existência de vínculos com serviços de saúde do município onde reside, Botucatu, março de 2002

Tabela 8 - Distribuição de freqüências absolutas e relativas na mostra de pacientes entrevistados no Serviço de Urgência/Emergência do HC - FMB segundo os motivos apontados para não freqüentar serviços de saủde locais e município de procedência, classificado de acordo com o Plano Diretor de Regionalização, Botucatu, março de 2002

Tabela 9 - Distribuição de freqüências absolutas e relativas na amostra de 50 pacientes, que citaram razões econômicas e facilidades de acesso para procura do serviço da UNESP, entrevistados no Serviço de Urgência/Emergência do HC - FMB, segundo razões apresentadas, Botucatu, março de 2002

Tabela 10 - Distribuição de freqüências absolutas e relativas na amostra de 224 pacientes, entrevistados no Serviço de Urgência/ Emergência do HC - FMB, que apontaram motivos ligados à situação do seu município para procura do serviço da UNESP, segundo razões apresentadas, Botucatu, março de 2002

Tabela 11 - Distribuição de freqüências absolutas e relativas na amostra de 321 pacientes, que apontaram motivos ligados à confiança depositada na UNESP para procura dos seus serviços, entrevistados no Serviço de Urgência/Emergência do $\mathrm{HC}$ - FMB, Botucatu, março de 2002 
Tabela 12 - Distribuição de freqüências absolutas e relativas dos tipos de serviços procurados para resolver o problema atual de saúde, na amostra de pacientes entrevistados no Serviço de Urgência/Emergência do HC -FMB, Botucatu, março de 2002 .....

Tabela 13 - Distribuição de freqüências absolutas e relativas na amostra de pacientes entrevistados no Serviço de Urgência/Emergência do HC - FMB, segundo o meio de transporte utilizado, Botucatu, março de 2002

Tabela 14 - Distribuição de freqüências absolutas e relativas na amostra de pacientes entrevistados no Serviço de Urgência/Emergência do HC - FMB, segundo o tempo transcorrido entre a saida do local onde se encontrava e chegada à UNESP e município de procedência, classificado de acordo com o Plano Diretor de Regionalização, Botucatu, março de 2002

Tabela 15 - Distribuição de freqüências absolutas e relativas nos questionários respondidos por médicos do Serviço de Urgência/Emergência do $\mathrm{HC}$-FMB que atenderam os pacientes entrevistados, segundo $o$ tipo de atendimento realizado e local, Botucatu, março de 2002 .......

Tabela 16 - Distribuição de freqüências absolutas e relativas nos questioná-rios respondidos por médicos do Serviço de Urgência/ Emergência do $\mathrm{HC}$ - FMB - PA e SE, que atenderam os pacientes entrevistados, segundo o tipo de atendimento realizado e município de procedência, classificado de acordo com o Plano Diretor de Regionalização, Botucatu, março de 2002 
Tabela 17 - Distribuição de freqüências absolutas e relativas nos questionários respondidos por médicos do Serviço de Urgêncial Emergência do HC - FMB que atenderam os pacientes entrevistados no PA, segundo a conduta médica adotada e município de procedência, classificado de acordo com o Plano Diretor de Regionalização, Botucatu, março de 2002

Tabela 18 - Distribuição de frequiências absolutas e relativas nos questionários respondidos por médicos do Serviço de Urgêncial Emergência do HC -FMB que atenderam os pacientes entrevistados no SE, segundo a conduta médica adotada e município de procedência, classificado de acordo com o Plano Diretor de Regionalização. Botucatu, março de 2002

Tabela 19 - Distribuição de freqüências absolutas e relativas na amostra de pacientes entrevistados no Serviço de Urgência/Emergência do HC - FMB, segundo o primeiro diagnóstico (Capítulo - CID 10) referido pelos entrevistados e município de procedência, classificado de acordo com o Plano Diretor de Regionalização. Botucatu, março de 2002

Tabela 20 - Distribuição de freqüências absolutas e relativas nos questionários respondidos por médicos do Serviço de Urgência/ Emergência do $\mathrm{HC}$-FMB, segundo o primeiro diagnóstico (Capítulo - CID 10) feito pelo médico e município de procedência, classificado de acordo com o Plano Diretor de Regionalização. Botucatu, março de 2002 


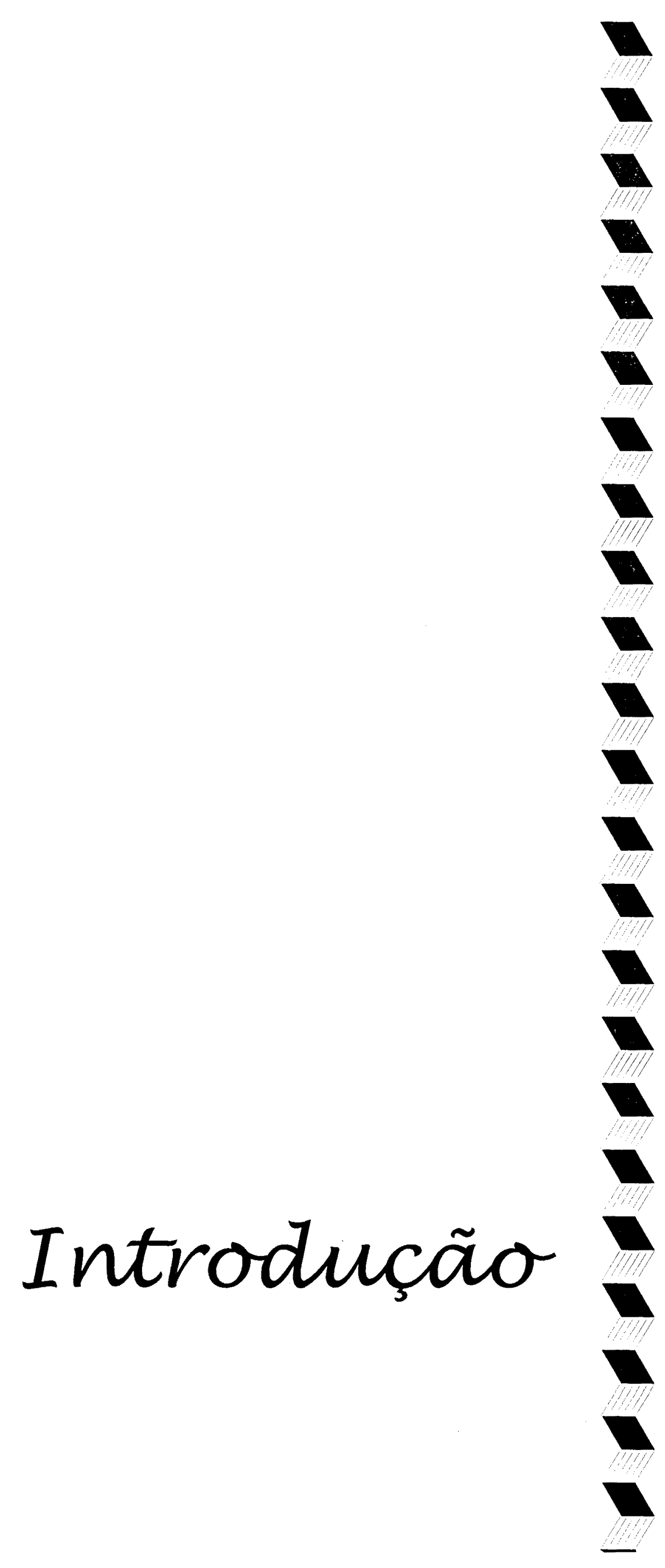




\section{Introdução}

A organização regionalizada e hierarquizada do atendimento em saúde tem enfrentado dificuldades para sua efetivação, necessitando de análise objetiva em cada região quanto aos aspectos políticos, econômicos, sociais e culturais, para que a regionalização do sistema seja um instrumento, não apenas regulatório, mas também emancipatório em direção à universalidade, à equidade e ao atendimento integral. Entendendo os termos regulatório e emancipatório segundo conceito apresentado por SANTOS (2001): Regulatório - "Trajetória entre um estado de ignorância que designo por caos e um estado de saber que designo por ordem" e Emancipatório "Trajetória entre um estado de ignorância que designo por colonialismo e um estado de saber que designo por solidariedade" (p. 78).

Partindo desta premissa, o presente estudo, realizado na região de Botucatu, Direção Regional de Saúde - DIR XI - do Estado de São Paulo, mediante análise de demanda ao serviço de referência em urgência-emergência de nível terciário, pretende contribuir para o diagnóstico de problemas da região que dificultam a integração dos serviços de saúde e apontar caminhos para sua solução.

O conceito de regionalização adotado neste estudo é derivado da definição de ROBAYO (1977). Implica na busca de melhor distribuição técnico-espacial, científica e operacional das ações de saúde distribuídas em níveis de atenção, articulados entre si, com a melhor eficiência, eficácia e efetividade dos serviços e com impacto epidemiológico e social. Neste conceito estão embutidas as noções de cobertura e acessibilidade. Cobertura, como resultante da oferta eficaz e organizada dos serviços de saúde para o atendimento das necessidades de toda a população, prestado em locais a que ela tenha acesso assegurado aos diferentes níveis assistenciais. Logo, a possibilidade de acesso aos serviços é condição necessária para que a cobertura universal seja alcançada pois a acessibilidade implica na existência de serviços em quantidade e qualidade, localização e disponibilidades apropriadas para satisfazer as necessidades da população referida, com aceitação e utilização dos serviços oferecidos por parte da comunidade (OPAS/OMS 1977).

A hierarquização dos níveis de atenção pressupõe uma organização piramidal baseada no perfil das necessidades, levando-se em conta que estas ocorrem em um determinado espaço e em um determinado tempo com freqüências diferentes, em que 
as menos complexas têm maior freqüência relativa que as mais complexas e que existe uma correspondência entre complexidade de problemas de saúde e custo social (CAPOTE MIR 1990).

Deste modo, os níveis de atenção são determinados a partir de critérios de hierarquização dos problemas, em que o nível primário corresponda a ações básicas de habilidade e tecnologia adequadas que assegurem abrangência de ação e resolutividade nesse nível; o segundo nível a problemas menos freqüentes e mais complexos e o terceiro nível a situações mais raras e altamente complexas que exigem habilidades e tecnologias mais avançadas. duas partes:

De acordo com CAPOTE MIR (1990), o princípio da hierarquização contém

“ a) Suficiência e insuficiência tecnológica de cada nível de atenção - Um nivel de atenção deve ter necessariamente uma suficiência resolutiva que o justifique e composição tecnológica que o caracterize. Pelo fato de ser insuficiente tecnologicamente para atender problemas que transcendam sua capacidade resolutiva ele depende de um nível de maior complexidade tecnológica que lhe sirva de referência.

b) Referência e contra-referência - A hierarquização exige um fluxo e contra-fluxo de pessoas e de informações gerenciais e técnicocientíficas dentro da rede de serviços de saúde denominados sistemas de referência e contrareferência" (p. 130).

Assim, o nível de menor complexidade, denominado primário, constitui ponto de contato com a população ou "porta de entrada do sistema", podendo ser uma estratégia para aumentar a cobertura das ações de saúde à população, cujas Unidades Básicas são fundamentais para a composição e função dos demais níveis.

Os níveis secundário e terciário correspondem a serviços especializados de complexidade tecnológica maior que atuam sobre a base referenciada pelo nível primário. Estes serviços, prestados por hospitais de diversos graus de complexidade, nos bairros e municípios que compõem a região, devem conectar-se entre si e com o nível primário, mediante mecanismos que os articulem numa dinâmica flexível de referência e contra-referência (ALMEIDA et al. 1998). Deste modo, a organização 
regionalizada dos serviços de saúde "constitui a expressão técnico-administrativa das inter-relações dos niveis de atenção" (ROBAYO 1977, p. 485).

A combinação de níveis de atenção, escala de complexidade e a articulação destes são essenciais à regionalização funcional do sistema de saúde, a qual é condição necessária para assegurar a máxima acessibilidade da população aos serviços de saúde (BARRENECHEA e TRUJILLO URIBE 1987).

A acessibilidade por sua vez, é condição para que seja alcançada a cobertura universal e pressupõe: acessibilidade geográfica que se refere à localização mais apropriada dos serviços de saúde; acessibilidade financeira que visa não causar despesas que impeçam o uso dos serviços; acessibilidade cultural que leva em conta os hábitos e costumes da população e acessibilidade funcional que atende a demanda real, está disponivel a qualquer momento, em caráter contínuo e tem um sistema de referência de fácil acesso (ALMEIDA et al. 1998).

Entretanto, para que a rede de serviços funcione é necessário que cada nível de complexidade seja resolutivo dos problemas de saúde individuais e coletivos de acordo com sua complexidade tecnológica. Segundo CAPOTE MIR (1990) a legitimidade social e a credibilidade política de um sistema local e regional de saúde advêm da capacidade de resolução das demandas em cada nível de atenção. Assim, a rede de serviços deve estar capacitada em todos os seus pontos de acesso, atendendose ao princípio da resolutividade e da integralidade.

A integralidade exige que o sistema local de saúde seja o espaço de intervenção integradora sobre indivíduos, famílias, ambientes coletivos, grupos sociais e meio ambiente, eliminando-se as "dicotomias entre ações preventivas e curativas, saúde individual e coletiva, atenção às pessoas e atenção ao meio" (CAPOTE MIR 1990, p. 132).

Os discursos referentes à regionalização, hierarquização e integralidade da assistência em saúde desde 1988 encontram-se incorporados na Constituição Federal (BRASIL 1988, p.133) a qual estabelece, em seu artigo 198, que "as ações $e$ serviços públicos de saúde integram uma rede regionalizada e hierarquizada $e$ constituem um sistema único, organizado de acordo com as seguintes diretrizes:

I - descentralização, com direção única em cada esfera de governo;

II - atendimento integral, com prioridade para as atividades preventivas, sem 
prejuizo dos serviços assistenciais;

III - participação da comunidade."

A integralidade da assistência à saúde constitui, pois, um princípio do Sistema Único de Saúde (SUS), com a explicitação de que deve ser "entendida como um conjunto articulado e contínuo das ações e serviços preventivos e curativos, individuais e coletivos, exigidos para cada caso em todos os niveis de complexidade do sistema" (BRASIL, 1991, p. 10). Este princípio doutrinário aponta para a indissociabilidade das ações preventivas e curativas.

No entanto, de acordo com JUNQUEIRA (1997), essa integralidade da atenção implica mudanças nos conceitos de saúde e assistência médica que envolvem a intersetorialidade, ou seja, uma nova dinâmica de gestão pública, comprometida com os resultados e impactos na qualidade de vida da população, mediante articulação intersetorial. Desta forma, as intervenções precisam ser realizadas no sentido de se alterarem os modelos assistenciais tradicionalmente vigentes, formulando, produzindo e desenvolvendo ações de promoção, recuperação e reabilitação, num processo articulado de ações integradas em que a promoção seja enfatizada.

A IX Conferência Nacional de Saúde, realizada em 1992, teve como tema central "Saúde: a municipalização é o caminho". Após essa Conferência, com a destituição do governo, reassumem a gestão da saúde profissionais engajados na continuidade da luta pela implantação do SUS, tendo com referência o documento “A ousadia de cumprir a lei” e a Norma Operacional Básica SUS 01/93 (NOB SUS 01/93). Dentre os princípios da NOB SUS 01/93 destaca-se o referente à organização dos serviços de saúde públicos e privados a partir de critérios de regionalização e hierarquização, seguindo as diretrizes da descentralização (BRASIL 1993).

Naquele momento surgiram divergências conceituais e metodológicas quanto à regionalização e sua implementação, dado que alguns a entendiam como alternativa à municipalização ou instância intermediária, com relacionamento direto com outras esferas de governo, e outros, como um processo de organização de serviços, a partir de articulações entre municípios que se propõem a estabelecer modos de cooperação. Uma das críticas à NOB $01 / 93$ foi quanto à lacuna deixada ao não abordar, de modo 
satisfatório, o caminho para melhor conceituar a regionalização e a operacionalização dos serviços (ALMEIDA 1995).

Segundo DALLARI (1992) "Descentralização significa a transferência de poderes a autoridades eleitas localmente" (p.40). Esse tipo de transferência adequou-se à forma de organização do país, significando "o reconhecimento do comando politico dos municipios, dos Estados e da União, em seus respectivos campos de atuação, sobre as ações e os serviços de saúde neles desenvolvidos" (p.40). Ou seja, a descentralização do sistema, tendo como base a municipalização, confere àos estados e municípios responsabilidades para os cuidados à saúde e para a cooperação entre estes, visando ao "equilíbrio do desenvolvimento e do bem-estar em âmbito nacional" (LOS, Art.23, par. único) (BRASIL 1991). Com a mesma interpretação legal ALMEIDA (1995) aponta para a não existência de Região como entidade jurídica e esclarece que o processo de regionalização decorre de uma organização ascendente, apoiada nas próprias estruturas municipais, a partir de municipios que livremente se juntam para a consecução de objetivos comuns.

Por ocasião da X Conferência Nacional de Saúde (BRASIL 1998), seus participantes reafirmaram o disposto na Constituição Federal de 1988 e na legislação do SUS, considerando-o imprescindível para a reformulação e implantação da organização das ações de saúde nas unidades e serviços do SUS, entendendo que toda a população brasileira tem direito, garantido pela Constituição, à atenção integral à saúde. Esta Conferência ratificou a Norma Operacional Básica 01/96, que representou avanços em relação à Norma Operacional Básica anterior - NOB SUS $01 / 93$ - pelas suas propostas de promoção e consolidação do pleno exercício do poder público municipal; caracterização da responsabilidade sanitária de cada gestor; reorganização do modelo assistencial, descentralizando para os municípios a atenção básica à saúde e diminuição relativa do repasse por produção, aumentando o repasse fundo a fundo. Determinou as condições de gestão para os municípios e estados em: gestão plena da atenção básica e gestão plena do sistema - municipal e estadual (ALMEIDA 1995; ALMEIDA et al. 2001; SOUZA 2001). Esta norma estabeleceu

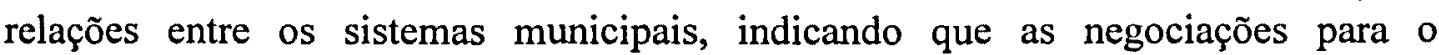
atendimento da população devem ser efetivadas entre gestores municipais. Relação essa que deve ser mediada pelo Estado, e eventuais impasses discutidos no âmbito da 
Comissão Intergestores Bipartite (CIB). Assim, do ponto de vista político, a regionalização é entendida como mobilização e articulação municipais que leva em consideração características geográficas, fluxo de demanda e disponibilidade de oferta de serviços. Entretanto, essa política de transferência de responsabilidade sem a correspondente transferência de recursos arrecadados pelo governo federal intensificou o desfinanciamento do sistema, ocorrendo uma prática de descentralização desfinanciada, implicando em controle e imposição de políticas segmentadas - campanhas verticais, Programa Saúde da Familia - pela falta de recursos.

As iniqüidades na alocação de recursos cada vez mais diminuídos nas áreas sociais, a malversação do dinheiro público decorrente da fragilidade do controle social, a ocorrência de ineficiências na gestão pública, dentre outros fatores, têm dificultado a organização do sistema em termos de hierarquização da rede de serviços, inviabilizando a integralidade, promovendo duplicidade de ações, elevando os gastos da atenção, com sérias implicações no agravamento da situação de enfermidade das pessoas (PAIM 1994; SANTOS 1994; RODRIGUES NETO 1996).

Estudo realizado por MENDES e CALDAS JÚNIOR (2001) mostrou que os serviços de saúde do município de Botucatu estão atendendo uma demanda espontânea de modo desarticulado e descontínuo, precariamente hierarquizado, recaindo sobre os serviços de maior complexidade a responsabilidade compensatória das deficiências de recursos dos demais.

No cotidiano dos serviços de saúde de maior complexidade, como os hospitais universitários, são freqüentes as reclamações sobre demanda de doentes que sobrecarregam, principalmente, os serviços de urgência, que poderiam ter sido atendidos em serviços de menor complexidade, ou ainda, sobre demanda de doentes que, se tivessem um acompanhamento adequado em uma Unidade Básica de Saúde, não chegariam a tal estado de agravamento da doença. Fala-se da falta de condições dos municípios pequenos para oferecer serviços de atenção primária e secundária com qualidade e dos encaminhamentos que profissionais de outros serviços de saúde fazem, desnecessariamente, para o nível terciário, ou seja, para o hospital universitário. 
Plantonistas da Central de Regulação Médica de Botucatu acreditam que aproximadamente $30 \%$ das solicitações de atendimento de urgência/emergência no nível terciário não se configuram como tal. Segundo esses plantonistas, é freqüente tanto a omissão de informações, quanto o exagero destas pelo médico solicitante, objetivando conseguir uma vaga para o paciente. Relatam que são numerosas as avaliações médicas inadequadas, gerando encaminhamentos indevidos e, deste modo, os médicos da Central de Regulação Médica têm desempenhado o papel de orientadores sobre avaliações clínicas e laboratoriais junto aos solicitantes. Comentam, ainda, ocorrências comuns de solicitações de atendimentos devidas a férias ou ausências de médicos e de funcionários que operam determinados aparelhos, situações essas que implicam em recusa de atendimento pela Central de Regulação Médica.

São muito comuns os comentários referentes à duplicidade de ações, afirmando-se, de modo muitas vezes preconceituoso, que grande número de pessoas procura mais de três serviços para avaliação do seu problema de saúde, "pervertendo o sistema que terá que remunerar várias vezes e por isto acaba remunerando mal os profissionais" (MENDES 2001). Não se observa uma análise do ponto de vista do usuário que busca atendimento em vários serviços $\mathrm{e}$, muitas vezes, não tem seu problema de saúde solucionado. Essas distorções dificultam o acesso aos serviços de saúde em todos os niveis, especialmente, no nivel de atenção terciária.

O novo modelo assistencial, baseado nas diretrizes constitucionais, centrado no direito de cidadania, na promoção e proteção da saúde, no atendimento integral, desenvolvido de modo organizado e hierarquizado em níveis de complexidade crescente, com acesso universal e igualitário, qualidade e eficiência, ainda não foi totalmente assegurado, apesar dos esforços que estão sendo empreendidos.

TOLEDO (1998) mostrou que a queda do número de internações, entre 1993 e 1997, nos hospitais conveniados/contratados pelo SUS, em todo o país, foi de $21 \%$, o que significou uma diferença de três milhões de pessoas. As causas desse decréscimo não guardam relação com a melhoria das condições de saúde, mas são decorrentes de limites financeiros aos gastos com internação. Embora haja quem relacione as causas às medidas racionalizadoras, como tratamento ambulatorial mais eficaz, evitando-se internações desnecessárias, foi também observado que, nesse 
período, não houve aumento do volume de procedimentos ambulatoriais. No município de Botucatu, segundo o Departamento de Informática do SUS DATASUS, excluindo-se o Hospital Psiquiátrico, houve uma redução de 6146 internações hospitalares entre 1994 e 1998, o que corresponde a uma diferença da ordem de $28,4 \%$ a menor.

Essa redução de internações pelo SUS em Botucatu decorreu, principalmente, do cancelamento do convênio entre o Hospital Misericórdia Botucatuense e o SUS e à resistência de médicos do outro hospital conveniado, Associação Beneficente dos Hospitais Sorocabana, em internar pacientes pelo SUS.

Foram apontados, no estudo de MENDES e CALDAS JÚNIOR (2001), alguns tipos de dificuldades enfrentadas pelos usuários para acesso aos serviços de atenção primária e secundária existentes no município de Botucatu, destacando-se as ligadas à organização dos serviços, à seleção baseada em interesses acadêmicos, e à exclusão de usuários não residentes ou não vinculados à região de abrangência do serviço.

O desemprego, a piora das condições de trabalho, a deterioração da qualidade de vida e, portanto, da saúde, aumentam a demanda aos serviços de saúde. As dificuldades de acesso aos níveis primário e secundário propiciam o agravamento das enfermidades, gerando grande demanda para os serviços mais complexos, caros e deficitários em termos de número de leitos, equipamentos e recursos humanos.

A carência de recursos assistenciais na região vem acarretando grande sobrecarga para o serviço de referência terciário, como apontado no estudo realizado por MENDES (1999), no qual apresenta o seguinte depoimento de um entrevistado: "Eu acho que hoje eu conto com um consenso muito grande por parte dos colegas, que em sua maior parte já são pessoas mais experientes de uma forma ou de outra, já têm aquele 'feeling', que já percebem quando o paciente vai encrencar e então a gente procura não assumir esse tipo de paciente, não por incompetência, mas por falta de estrutura."

A situação passa a exigir integração entre serviços e profissionais para estabelecimento de uma política de assistência à saúde na região que priorize a acessibilidade da população aos serviços de saúde como direito de cidadania, observando-se esse preceito legal do SUS. 
Embora, teoricamente, as pessoas tenham o direito aos cuidados de saúde prestados pelo Hospital da Faculdade de Medicina de Botucatu (HC - FMB), a sua distância do centro urbano, as dificuldades e os custos de transporte, que incidem mais significativamente nos individuos de baixa renda, podem contribuir para dificultar seu acesso.

Restrições ao financiamento do SUS têm repercutido de maneira importante sobre a assistência à saúde. No município de Botucatu observam-se:

- rompimento de convênio entre o hospital Misericórdia Botucatuense e o SUS;

- redução de internações em razão dos cortes orçamentários no hospital universitário, tanto de recursos próprios da Universidade quanto os referentes ao "teto" financeiro do SUS;

- leitos ociosos em hospital conveniado.

Segundo CALDAS JÚNIOR (1999), os Hospitais Universitários (HUs) ganharam expressão no Brasil nos anos 60 e 70, quando da expansão das escolas médicas, com a finalidade de servir como campo de estágio para formação de médicos e outros profissionais de saúde. São unidades complexas do ponto de vista organizacional, administrativo e jurídico. Os HUs vêm mantendo suas características de unidades de saúde, ambulatoriais e de internação altamente especializadas, via de regra as únicas referências terciárias de regiões e mesmo de estados, muitas vezes a única alternativa de acesso gratuito da população ao atendimento de qualidade. São ainda centros de formação de profissionais e de investigação científica, integrando ensino, pesquisa e prestação de serviços à população. Como unidades de saúde públicas, submetem-se às normas constitucionais e legais e, deste modo, os HUs estão incluídos no SUS e a eles se aplicam princípios estabelecidos no Artigo $7^{\circ}$. da Lei $n^{0} 8.080$ - Lei Orgânica da Saúde, tais como:

a . universalidade de acesso;

b. integralidade da assistência;

c. igualdade de assistência, sem preconceitos ou privilégios de qualquer espécie;

d. divulgação de informações quanto ao potencial dos serviços de saúde e a sua utilização pelo usuário; 
e. participação da comunidade;

Com o intuito de ressalvar as peculiaridades de unidades de ensino e assistência, a Lei Orgânica da Saúde determina, em seu artigo 45, que "os serviços de saúde dos hospitais universitários e de ensino integram-se ao Sistema Único de Saúde (SUS), mediante convênio, preservada a sua autonomia administrativa, em relação ao patrimônio, aos recursos humanos e financeiros, ensino, pesquisa $e$ extensão, nos limites conferidos pelas instituições a que estejam vinculados" (BRASIL 1991, p.21). Atualmente, essas relações ocorrem através de uma modalidade de contrato denominada co-financiamento, sendo estabelecido um valor fixo para procedimentos ambulatoriais e de internações. Procedimentos estratégicos tais como campanhas executadas de maneira vertical, visando a agravos específicos tais como: catarata, varizes e os transplantes ficam fora desse valor fixo e o pagamento se dá por produção.

Apesar destas determinações legais, os HUs mantêm-se, por vezes, à margem das instâncias legalmente constituídas pelo SUS nas deliberações sobre suas políticas assistenciais.

A presença de um hospital universitário há mais de 30 anos em Botucatu, uma região carente de recursos médicos, suas disponibilidades financeiras, seus recursos tecnológicos, materiais e humanos o diferenciam de tal forma dos demais serviços dessa região a ponto de gerar na população uma cultura do tipo: "se tiver que morrer, que seja no Hospital da Faculdade", até pela observação de comportamentos preconceituosos existentes entre profissionais do hospital universitário em relação aos profissionais de outros serviços de saúde da região.

Estudo realizado por MENDES (1999) apontou relatos de profissionais de saúde de municípios menores da região de Botucatu de que, muitas vezes, as pessoas querem ser encaminhadas ao hospital universitário mesmo sem que seja constada essa necessidade.

Por outro lado, é muito citada, especialmente no meio hospitalar, a existência de prática adotada por ocupantes de cargos políticos da região, de oferecimento de transporte gratuito aos munícipes, investindo recursos na compra de ônibus e ambulâncias e deixando de investir em materiais ou equipamentos para suas Unidades Básicas de Saúde. A justificativa é de que isto agrada mais a população, 
além de ser preferivel reclamações de mau atendimento ocorrido em um outro município e não no próprio.

Enfim, o processo de regionalização tem apresentado muitos entraves em seu desenvolvimento, tendo recebido sérias críticas dos participantes da $\mathrm{XI}^{\mathrm{a}}$ Conferência Nacional de Saúde (BRASIL 2000). Dentre as críticas formuladas nessa Conferência destacam-se questões ligadas ao financiamento para a constituição de redes descentralizadas e regionalizadas, principalmente em relação à média e alta complexidade; desigualdades no atendimento; ausência do Estado como articulador no processo de regionalização; prefeitos sem compromisso político com a saúde; modelos de atenção locais dependentes excessivamente do Ministério da Saúde devido aos mecanismos de financiamento; inviabilidade de consórcios entre municípios pequenos e pobres; administrações municipais que não dispõem de diagnóstico de necessidades e possibilidades do sistema local de saúde; abandono das estratégias de promoção da saúde através de políticas intersetoriais; atenção básica ineficaz; baixa resolutividade; dificuldades de encaminhamento para serviços de média e alta complexidade; inexistência ou precariedade de serviços de urgência/emergência, com sobrecarga dos existentes em centros urbanos maiores; falta de comprometimento dos profissionais com a população e seus problemas.

Recentemente, com a Norma Operacional de Assistência à Saúde - NOAS SUS 01/2002, que revogou a NOAS 2001, verifica-se um esforço para regionalização e hierarquização do sistema, visando à organização do SUS, segundo seus princípios de acessibilidade e eqüidade. O objetivo geral da NOAS SUS 01/02 é: "Promover maior eqüidade na alocação de recursos e no acesso da população às ações $e$ serviços de saúde em todos os niveis de atenção" (BRASIL 2002). Esta Norma Operacional objetivou ampliar a responsabilidade dos municípios na atenção básica, definir o processo de regionalização, criar mecanismos para fortalecimento da gestão do SUS e atualizar os critérios de habilitação de Estados e Municípios.

O capitulo 1 dessa norma estabeleceu o processo de regionalização e de hierarquização dos serviços de saúde justificados pela busca de maior eqüidade: 
identificação de prioridades de intervenção e de conformação de sistemas funcionais de saúde, não necessariamente restritos à abrangência municipal, mas respeitando seus limites como unidade indivisível, de forma a garantir o acesso dos cidadãos a todas as ações e serviços necessários para a resolução de seus problemas de saúde, otimizando os recursos disponiveis" (p. 1)

Quanto à assistência, recomendou a elaboração de Plano Diretor de Regionalização na perspectiva de garantir:

"A - O acesso dos cidadãos, o mais próximo possível de sua residência, a um conjunto de ações e serviços vinculados às seguintes responsabilidades mínimas:

- assistência pré-natal, parto e puerpério;

- acompanhamento do crescimento e desenvolvimento infantil;

- cobertura universal do esquema preconizado pelo Programa Nacional de Imunizações, para todas as faixas etárias;

- ações de promoção da saúde e prevenção de doenças;

- tratamento das intercorrências mais comuns na infância; incidência;

- atendimento de afecções agudas de maior

- acompanhamento de pessoas com doenças crônicas de alta prevalência;

- tratamento clínico e cirúrgico de casos de pequenas urgências ambulatoriais;

- tratamento dos distúrbios mentais e psicossociais mais freqüentes;

- controle das doenças bucais mais comuns;

- suprimento / dispensação dos medicamentos da Farmácia Básica.

B - O acesso de todos os cidadãos aos serviços necessários à resolução de seus problemas de saúde, em qualquer nível de atenção, diretamente ou mediante 0 estabelecimento de compromissos entre gestores para 0 atendimento de referências intermunicipais". (p. 2) 
Cabe aqui ressaltar que há críticas a essa norma, incluindo a de limitação e/ou restrição à atenção básica, entretanto, ela coloca efetivamente em foco a questão da regionalização e hierarquização.

Há a necessidade de identificação e reconhecimento do processo saúdedoença no município e na região, bem como, dos problemas e necessidades da população para que possam ser estabelecidos modos de intervenção, inclusive intersetoriais, visto que as necessidades básicas da população estão relacionadas a fatores que estão fora do setor saúde.

D'esta foram, a atenção básica não deve se limitar a normas ou a procedimentos pré-estabelecidos, mas desenvolvida mediante ações, ao nível local, as mais abrangentes possíveis.

No item que trata da política de atenção de alta complexidade/custo no SUS, estabeleceu:

"A responsabilidade do Ministério da Saúde sobre a política de alta complexidade/custo se traduz na definição de normas nacionais, no controle do cadastro nacional de prestadores de serviços, na vistoria de serviços quando lhe couber, de acordo com as normas de cadastramento estabelecidas pelo próprio Ministério da Saúde, na definição de incorporação dos procedimentos a serem ofertados à população pelo SUS, na definição do elenco de procedimentos de alta complexidade, no estabelecimento de estratégias que possibilitem o acesso mais equânime diminuindo as diferenças regionais na alocação dos serviços, na definição de mecanismos de garantia de acesso para as referências interestaduais, na busca de mecanismos voltados à melhoria da qualidade dos serviços prestados e no financiamento das ações" (p. 5 e 6 ).

A Secretaria de Estado da Saúde de São Paulo adotou estratégias e diretrizes para a implantação da NOAS no Estado, recomendando o envolvimento do Conselho de Secretários Municipais de Saúde (COSEMS) em todas as etapas do processo de implantação e criação de um grupo para coordenação da implantação da NOAS no Estado, com a participação da Coordenadoria de Planejamento de Saúde, Coordenadoria de Saúde da Região Metropolitana da 
Grande São Paulo, Coordenadoria de Saúde do Interior, Coordenadoria de Institutos de Pesquisas e COSEMS (BRASIL 2001).

A NOAS - SUS 01/02 permite avanços em relação ao papel das Secretarias Estaduais de Saúde no sistema, pela condução junto com os municípios do processo de regionalização; reforça o comando único no nível municipal e recupera a proposta de Programação Pactuada Integrada (PPI), apresentada na NOB 96; propõe os Planos Diretores de Regionalização (PDR) e Planos Diretores de Investimentos (PDI).

Porém, esta norma vem recebendo críticas referentes à concepção de integralidade da assistência à saúde a qual é colocada na perspectiva do cuidado médico individual, curativo, numa visão racionalizadora de oferta de serviços voltados ao atendimento de uma demanda, ou seja, uma concepção que se limita à garantia da assistência médica e não à integralidade da atenção à saúde (TEIXEIRA 2002). Outras críticas dizem respeito às medidas que prevêem centralização dos recursos e dos processos burocráticos no Ministério da Saúde, com discreta divisão de poder com os estados (CARVALHO 2001).

O processo de implantação da NOAS/2002 na DIR XI - Botucatu encontra-se em fase inicial ou preliminar. Observa-se, neste cenário de estudo, uma desarticulação de serviços, precariamente hierarquizados, estando envolvidos interesses políticos, questões econômicas, sociais e culturais, com sérias repercussões para a saúde da população, gerando grande demanda aos serviços de emergência, seja por problemas de saúde que não se configuram como urgência/emergência e que poderiam ser atendidos em nível secundário ou até mesmo primário, seja por agravamento de doenças por falhas nas redes básica e secundária.

A igualdade de acesso aos cuidados disponíveis para a mesma necessidade implica em igual direito aos serviços disponíveis para cada indivíduo, uma distribuição justa baseada nas necessidades de cuidados de saúde, facilidade de acesso em cada área geográfica e remoção de outras barreiras ao acesso (WHITEHEAD 1992).

Nesse processo de regionalização, além da implantação da NOAS, está ocorrendo um novo momento na atenção básica marcado pela introdução do 
Programa Saúde da Família. Este programa centraliza a atenção na família e seu ambiente físico e social, possibilitando às equipes uma compreensão mais ampla do processo saúde/doença e da necessidade de intervenções que podem ir além das práticas curativas. A equipe de Saúde da Família deve estar vinculada à rede de serviços de forma a garantir atenção integral aos indivíduos e famílias, assegurandose a referência e contra-referência aos diversos níveis para resolução dos problemas identificados.

A organização da assistência à saúde, regionalizada e integrada em direção à equidadé, é um processo político e social e sua implantação não depende apenas de normas legais. Mesmo tendo ocorrido ampla discussão durante a concepção de uma norma, podem surgir conflitos de interesses legítimos entre os atores e confrontos entre interesses particulares e interesses públicos.

Minha atuação, há muitos anos, no $\mathrm{HC}$ - FMB em atividades assistenciais, administrativas e de ensino de enfermagem, a inquietude frente à desorganização do sistema de saúde e suas sérias implicações, sobretudo quanto à equidade e qualidade da assistência em todos os níveis, nesta região, foi o motivo da idealização do presente projeto.

Assim, um estudo visando à identificação de barreiras que estão dificultando esse processo de regionalização das ações e serviços de saúde na DIR XI, a busca de possíveis soluções e de avanços para além das diretrizes apresentadas em normas operacionais constitui a razão maior deste trabalho. 


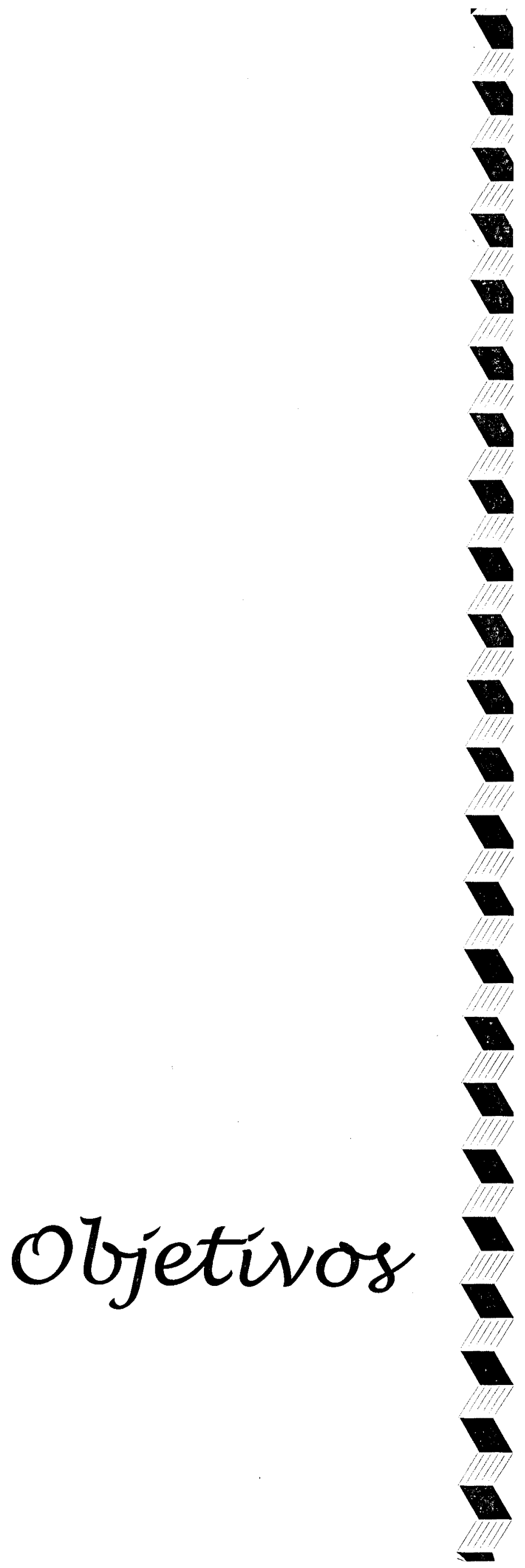




\section{Objetivos}

\section{Geral}

Estudar o processo de regionalização do atendimento nos serviços de saúde na região da DIR XI, tendo como referência a atenção em urgência/emergência prestada pelo Hospital das Clínicas da Faculdade de Medicina de Botucatu UNESP.

\section{Específicos}

a) Descrever e analisar:

- a demanda regional referida para a Central de Regulação Médica do HC FMB, quanto aos seus motivos e atendimentos recebidos.

- a demanda e sua motivação, segundo informações dos doentes que comparecerem ao Pronto Atendimento (PA) e/ou Setor de Emergência (SE) do HC - FMB.

- o atendimento médico prestado no PA e SE do HC - FMB e, a partir dele, a natureza e complexidade do problema de saúde apresentado e sua relação com os níveis de atenção em saúde.

- o processo de regionalização da assistência na perspectiva do gestor regional, de gestores municipais e do responsável pelo Serviço de Urgência/Emergência.

b) Contribuir para o desenvolvimento de um processo de regionalização da atenção à saúde que promova intervenções significativas no processo saúde-doença da população desta região. 
둔

.

-

. 


\section{Método}

\subsection{Caracterização do cenário do estudo}

\subsubsection{Região do estudo}

O estudo foi desenvolvido na região da DIR. XI que compreende uma área de $6.394 \mathrm{~km}^{2}$, população urbana de 425.532 habitantes e rural de 72.443 habitantes, totalizando 497.975 habitantes (SEADE 2001a).

O Município-sede, Botucatu, situa-se em uma área de $1496 \mathrm{~km}^{2}$, na região centro-sul do Estado de São Paulo, a $240 \mathrm{~km}$ da capital. A população urbana de Botucatu, segundo Censo Demográfico de 2000, é de 103.793 habitantes e rural de 4.319 , com taxa de crescimento anual de 1,75.

Dentro da DIR XI, os municípios habilitados nas modalidades de gestão NOAS, no ano de 2002 foram: Laranjal Paulista, Fartura, Bofete, Anhembi, Torre de Pedra, Tejupá, Taquarituba e Piraju, todos em Gestão Plena da Atenção Básica Ampliada (GPAB-A). Os demais se encontravam-se em processo de habilitação.

A Região da DIR XI possui dois ambulatórios regionais de especialidades chamados Núcleos de Gestão Assistencial (NGA), localizados nos municípios de Botucatu e Avaré. A região conta com 79 Unidades Básicas de Saúde, 42 equipes do Programa Saúde da Família (PSF), duas equipes do Programa de Agentes Comunitários de Saúde (PACS), 20 hospitais, sendo dois não conveniados/contratados, 16 hospitais gerais, um hospital universitário, com um total de 975 leitos e um hospital psiquiátrico com 240 leitos. Hả também três laboratórios estaduais, nos municípios de Botucatu, Avaré e Pirajú e dois laboratórios municipais, em São Manuel e Laranjal Paulista.

Os municípios que compõem a região e algumas de suas características são apresentados no Quadro 1. 
Quadro 1 - Municípios que compõem a DIR XI com tipo de gestão (segundo a NOB/SUS 96), número de habitantes, número de Unidades Básicas de Saúde (UBS), de Programa de Agentes Comunitários de Saúde (PACS) e Equipes do Programa Saúde da Familia (PSF). Botucatu, janeiro de 2003

\begin{tabular}{|c|c|c|c|c|c|c|}
\hline № & Município & $\begin{array}{l}\text { Tipo de } \\
\text { Gestão }\end{array}$ & Hab. & UBS & PACS & PSF \\
\hline$* 1$ & Águas de Santa Bárbara & $\mathrm{PAB}$ & 5.521 & 1 & 0 & 0 \\
\hline$* 2$ & Anhembi & $\mathrm{PAB}$ & 4.537 & 2 & 0 & 0 \\
\hline 3 & Arandu & PAB & 6063 & 1 & 1 & 0 \\
\hline 4 & Areiópolis & $\mathrm{PAB}$ & 10.295 & 1 & 0 & $3 * *$ \\
\hline 5 & Avaré & PS & 76.400 & 8 & 0 & $3+2 * *$ \\
\hline$* 6$ & Barão de Antonina & PAB & 2.794 & 1 & 0 & 1 \\
\hline$* 7$ & Bofete & $\mathrm{PAB}$ & 7.355 & 1 & 0 & 5 \\
\hline 8 & Botucatu & $\mathrm{PAB}$ & 108.112 & 14 & 0 & 0 \\
\hline 9 & Cerqueira César & $\mathrm{PAB}$ & 15.143 & 1 & 0 & 0 \\
\hline 10 & Conchas & PS & 14.905 & 3 & 0 & 5 \\
\hline${ }^{*} 11$ & Coronel Macedo & PAB & 5.584 & 1 & 1 & 0 \\
\hline 12 & Fartura & PAB & 15.007 & 2 & 0 & 1 \\
\hline$* 13$ & Iaras & PAB & 3.057 & 1 & 0 & 1 \\
\hline 14 & Itaí & $\mathrm{PAB}$ & 21.053 & 2 & 0 & 0 \\
\hline 15 & Itaporanga & PAB & 14.316 & 1 & 0 & 0 \\
\hline 16 & Itatinga & $\mathrm{PAB}$ & 15.438 & 1 & 0 & 0 \\
\hline 17 & Laranjal Paulista & PS & 22.081 & 4 & 0 & 0 \\
\hline 18 & \begin{tabular}{|l|} 
Manduri \\
\end{tabular} & $\mathrm{PAB}$ & 8.260 & 1 & 0 & 0 \\
\hline 19 & Paranapanema & PAB & 15.489 & 2 & 0 & 1 \\
\hline$* 20$ & Pardinho & $\mathrm{PAB}$ & 4.737 & 1 & 0 & 0 \\
\hline *21 & Pereiras & $\mathrm{PAB}$ & 6.256 & 1 & 0 & 3 \\
\hline 22 & Piraju & $\mathrm{PAB}$ & 27.871 & 9 & 0 & 8 \\
\hline$* 23$ & Porangaba & $\mathrm{PAB}$ & 6.628 & 2 & 0 & 2 \\
\hline$* 24$ & Pratânea & $\mathrm{PAB}$ & 3.948 & 1 & 0 & 0 \\
\hline 25 & São Manuel & PS & 36.442 & 5 & 0 & 1 \\
\hline$* 26$ & \begin{tabular}{|l} 
Sarutaiá \\
\end{tabular} & PAB & 3.733 & 1 & 0 & 0 \\
\hline 27 & Taguaí & $\mathrm{PAB}$ & 7.450 & 1 & 0 & 0 \\
\hline 28 & Taquarituba & $\mathrm{PAB}$ & 21.978 & 4 & 0 & 3 \\
\hline$* 29$ & Tejupá & PAB & 5.332 & 3 & 0 & 0 \\
\hline$* 30$ & Torre de Pedra & PAB & 2.190 & 1 & 0 & 0 \\
\hline 31 & Itaberá*** & $\mathrm{PAB}$ & 19.207 & 2 & 0 & 3 \\
\hline
\end{tabular}

$\left(^{*}\right)$ Municípios que não possuem hospital

PAB - Plena da Atenção Básica PS - Plena do Sistema

$\left({ }^{* *}\right)$ - Equipes qualificadas junto ao Ministério da Saúde em processo de implantação.

$\left({ }^{* * *}\right)$ O município passou a integrar a DIR XI em Janeiro de 2003. 
Foi realizado um estudo com o objetivo de elaborar o Plano Diretor de Regionalização, visando à habilitação dos municípios de acordo com a NOAS - SUS 01/2002, conforme instruções da Portaria do Ministério da Saúde $n^{0} 544$ de 11 de abril de 2001 (BRASIL 2001). Essa proposta é visualizada no mapa da região que consta do anexo 1. Nesse mapa observam-se 15 municípios-sede de módulo assistencial: Laranjal Paulista, Conchas, Botucatu, São Manuel, Itatinga, Avaré, Cerqueira César, Arandu, Paranapanema, Itaí, Piraju, Fartura, Taquarituba, Taguaí e Itaporanga e 15 municípios adscritos: Pereiras, Porangaba, Torre de Pedra, Bofete, Anhembi, Pardinho, Areiópolis, Pratânea, Iaras, Águas de Santa Bárbara, Manduri, Sarutaiá, Tejupá, Coronel Macedo e Barão de Antonina. Quanto ao município de Itaberá ainda não está definida sua condição, se sede de módulo ou adscrito. No ano de 2002 o município de Taguaí passou à condição de adscrito.

Município-sede de módulo assistencial, segundo a NOAS/2002, é aquele que apresenta a capacidade de ofertar um conjunto mínimo de procedimentos de média complexidade, compreendendo atividades ambulatoriais, de apoio diagnóstico e terapêutico e de internação hospitalar, correspondente ao primeiro nível de referência intermunicipal, com suficiência, para sua população e para a população de outros municípios a ele adscritos.

O município de Botucatu deverá assumir a condição de Sede de Módulo Assistencial e de Pólo, dada a presença do hospital universitário no município.

Município-sede de módulo assistencial e pólo é o que apresenta papel de referência para outros municípios da região de saúde em qualquer nível de atenção.

Conforme o Índice Paulista de Responsabilidade Social, que avalia os municípios segundo critérios de riqueza municipal, longevidade e escolaridade, os municípios da região da DIR XI ocupam o agrupamento 3, grupo de municípios saudáveis e de baixo desenvolvimento econômico (SEADE 2001b).

$O$ indice de exclusão social que analisa os temas: Padrão de Vida Digno pobreza, emprego e desigualdade; Conhecimento - anos de estudo e alfabetização; Risco Juvenil - concentração de jovens e violência, faz uma pontuação entre zero e um, donde as piores condições de vida equivalem a valores próximos a zero e as melhores situações sociais estão próximas de um, considerando que pontuação menor 
que 0,4 refere-se a situações de maior exclusão social. Os municípios da DIR XI, por esse índice, apresentaram no ano de 2000 , pontuação entre 0,4 e 0,6 , como a maioria dos municípios paulistas. Nesta região, contribuíram para essas pontuações, que não apontam maior gravidade de exclusão social, os baixos índices de desemprego formal e de desigualdade social (POCHMANN M; AMORIM R 2003).

Quanto à mortalidade na região em 1999, o coeficiente de mortalidade total na região, por 100.000 habitantes, foi de 244,12. Os percentuais de óbitos por Capítulo da CID 10 em 1999, segundo a Fundação SEADE, foram: Doenças do Aparelho Circulatório - 30,7; Doenças do Aparelho Respiratório - 10, 7; Causas externas - 8,1; Doenças do Aparelho Digestivo - 5,4; Algumas Doenças Infecciosas e Parasitárias 3,4; Doenças Endócrinas Nutricionais e Metabólicas - 4,9; Algumas Afecções originadas no período perinatal - 2,6; Doenças do Aparelho geniturinário - 1,5 e todas as demais $-4,0$.

Os Coeficientes de Mortalidade, por 100.000 habitantes, por alguns tipos de causa de óbito das doenças do Aparelho Circulatório, em 1999, foram: Doenças Hipertensivas - 24,85; Doenças isquêmicas do coração - 76,46; Infarto do miocárdio 49,50; Doenças cerebrovasculares - 69,72 (SEADE 1999).

Comparando com as demais regiões do Estado de São Paulo, a região de Botucatu apresenta o segundo maior índice de mortalidade por doenças do Aparelho Circulatório. A proporção de óbitos precoces (menores de 60 anos de idade) por Acidente Vascular Cerebral - AVC (número de óbitos precoces por AVC dividido pelo total de óbitos por AVC e multiplicado por 100) foi de 20,06 na região, no ano de 2001 e a proporção de óbitos precoces por Diabetes Mellitus (número de óbitos precoces por Diabetes Mellitus dividido pelo total de óbitos por Diabetes Mellitus e multiplicado por 100) foi de 21,48. A taxa de mortalidade por Tuberculose (número de óbitos por tuberculose por 100.000 habitantes) foi de 2,57 e a taxa de incidência de Tuberculose Pulmonar Bacilífera (número de casos novos de Tuberculose Bacilífera por 100.000 habitantes) foi de 11,25 em 2001 na região da DIR XI (SÃO PAULO 2001).

O coeficiente de mortalidade infantil (óbitos de menores de um ano por 1000 nascidos vivos) em 2001, na região, foi de 16,73 e de mortalidade neonatal (óbitos de 
crianças menores de 28 dias por 1000 nascidos vivos) foi de 10,50. O percentual de óbitos infantis sem assistência médica foi de 4,38 (SEADE 2001a).

No ano de 2000, o percentual de partos cesáreos na região foi de 40,43 . O percentual de nascidos vivos com baixo peso ao nascer $(<2.550 \mathrm{~g})$ foi de 9,00 . 0 percentual de mães adolescentes, no mesmo ano, foi de 25,13. Em uma série histórica de 1994 a 2000, a região da DIR XI vem apresentando o segundo maior percentual de mães adolescentes dentre as demais regiões do estado de São Paulo (SEADE 2001a).

$\mathrm{O}$ coeficiente de mortalidade materna, (número de óbitos em mulheres por causas relacionadas à gravidez, parto e puerpério por 100.000 nascidos vivos) na região, em 2001, foi de 61,04 e o percentual de parturientes com cobertura de 7 ou mais consultas pré-natais 67,04 . O coeficiente de mortalidade por câncer de colo e porção não especificada de útero (número de óbitos por câncer de colo e porção não especificada de útero por 100.000 mulheres) foi de 7,13; e o de mortalidade por câncer de mama (número de óbitos por câncer de mama por 100.000 mulheres) foi de 12,28 (SÃO PAULO 2001).

\subsubsection{Local do estudo}

\section{Faculdade de Medicina de Botucatu - UNESP}

A Faculdade de Medicina de Botucatu iniciou suas atividades no ano de 1963, integrando a extinta Faculdade de Ciências Médicas e Biológicas de Botucatu FCMBB, criada pela Lei 6860, de 22 de julho de 1962.

Em 1976, a partir da agregação dos antigos Institutos Isolados de Ensino Superior do Estado de São Paulo, passou a integrar a Universidade Estadual Paulista "Júlio de Mesquita Filho" - UNESP, pela Lei 952 de 30 de janeiro de 1976.

A Faculdade de Medicina conta com 13 Departamentos de ensino: Anestesiologia; Cirurgia e Ortopedia; Clínica Médica; Dermatologia e Radioterapia; Doenças Tropicais e Diagnóstico por Imagem; Ginecologia e Obstetrícia; Neurologia e Psiquiatria; Oftalmologia, Otorrinolaringologia e Cirurgia de Cabeça e Pescoço; Patologia; Pediatria; Saúde Pública, Urologia e Enfermagem. 
A Faculdade oferece dois Cursos de Graduação, o de Medicina, com noventa vagas e o de Enfermagem, com trinta vagas. A Faculdade de Medicina oferece ainda Programas de Residência Médica, com 304 médicos residentes matriculados em seus programas e mantém oito Cursos de pós-graduação, estando com 310 alunos matriculados no Mestrado e 132 no Doutorado, no ano de 2002.

\section{Hospital das Clínicas da Faculdade de Medicina de Botucatu - UNESP}

O Hospital das Clínicas iniciou suas atividades em 1967, com 48 leitos, atualmente sua capacidade é de 372 leitos, ocupa uma área de $44.794,35 \mathrm{~m}^{2}$. Conta com um corpo clínico formado por médicos contratados e docentes, num total de 316 membros, e um quadro de pessoal de enfermagem e apoio num total de 1.417 funcionários. Atualmente o Hospital das Clínicas dispõe de um Centro de Diagnóstico por Imagem, com equipamentos de Ressonância Magnética, Radiologia Digital, Tomografia e Ultra-som, além dos serviços de Quimioterapia, Hemocentro, Partos de Risco, Endoscopia, Fisiodiagnóstico, Reabilitação, Medicina Nuclear, Hemodiálise.

A integração da Faculdade de Medicina/Hospital das Clínicas com a comunidade tem sido progressivamente maior. O Centro de Saúde Escola, criado em 1972, com duas Unidades, localizadas em dois bairros da cidade, distantes entre 5 e 7 $\mathrm{km}$ do Campus da UNESP, vem desenvolvendo atividades de assistência primária à saúde, além de ser um campo de estágio para alunos de medicina e enfermagem, médicos residentes e outros profissionais de saúde.

\section{Pronto Socorro do Hospital das Clínicas da Faculdade de Medicina.}

O Pronto Socorro do Hospital das Clínicas da Faculdade de Medicina de Botucatu - UNESP (PS) é a única referência de todos os municípios que compõem a DIR - XI para procedimentos de alta complexidade em urgência/emergência. É constituído pelas unidades de Pronto Atendimento, Setor de Emergências, Enfermaria de Retaguarda e Triagem Médica de Especialidade, com as seguintes sub unidades:

- Pronto Atendimento Adulto

- Emergência Adulto 
- Emergência Infantil

- Enfermaria de Retaguarda Adulto (22 leitos)

- Enfermaria de Retaguarda Infantil (10 leitos)

- Triagem Médica de Especialidades para atendimento de doenças crônicas.

Além da assistência, o ensino e a pesquisa constituem suas finalidades. A média mensal de atendimentos no Pronto Atendimento (PA) e no Setor de Emergência (SE) tem sido de aproximadamente 12 mil consultas médicas, o que não equivale à demanda de doentes, visto que um doente pode ser atendido por médicos de várias especialidades. São doentes que buscam espontaneamente o serviço, ou são encaminhados por outros serviços do município e região, ou mesmo chegam trazidos pela Unidade de Resgate do Corpo de Bombeiros, vítimas de vários tipos de acidentes.

A entrada do doente no Pronto Socorro pode se dar via Pronto Atendimento (PA), entendido como atendimento de urgência, ou pelo Setor de Emergência (SE).

Para ser atendido no PA, o doente abre ficha de consulta na Seção de Registro e aguarda em sala de espera a chamada pelo interfone. A primeira chamada é feita pela enfermagem, que afere os sinais vitais e registra as principais queixas. Nesse momento, se constatada alguma anormalidade que indique necessidade de cuidados imediatos, o doente é encaminhado ao Setor de Emergência. Caso contrário, aguarda chamada pelo médico do PA para seu atendimento. Após a consulta, o doente pode ser dispensado, encaminhado ao Setor de Emergência ou a outro serviço de saúde.

No Setor de Emergência são atendidos os doentes que requerem cuidados imediatos e todos os pacientes que utilizam macas ou cadeira de rodas para locomoção. Nessas condições, o doente é atendido diretamente nas salas de emergências clínica ou cirúrgica, conforme o caso, pelo médico plantonista (clínicos, cirurgiões, pediatras, médicos residentes e docentes, além de internos do sexto ano de medicina). Conforme escala diária, todas as especialidades médicas do Hospital das Clínicas de Botucatu, além do corpo de palntão, têm plantonistas à distância para serem acionados caso haja necessidade.

A Triagem Médica de Especialidades destina-se ao atendimento de portadores de doenças crônicas, conforme o seguinte fluxo: 
1. Os doentes são atendidos pelas Unidades Básicas de Saúde dos municípios que compõem a DIR XI e de outros municípios do Estado de São Paulo e de fora dele.

2. Os doentes que não encontram resolução para sua doença no seu município são encaminhados à Triagem de Especialidades mediante agendamento prévio por telefone, efetuado pela própria Unidade Básica, que dispõe de cotas de consultas mensais.

3. Na Triagem de Especialidades, o médico avalia o estado de saúde do doente e pode adotar as seguintes condutas:

a) Reencaminhar o doente ao serviço de origem, com orientação sobre o tratamento;

b) Registrar o paciente no ambulatório de especialidades para seguimento;

c) Encaminhar o paciente ao pronto Socorro (casos graves);

d) Internar o paciente na enfermaria de especialidades.

Deste modo, o Pronto Socorro/Triagem Médica é uma das portas de entrada do Hospital das Clinicas da FM de Botucatu.

\section{Central de Regulação Médica}

Em 1998, a Coordenadoria de Saúde do Interior da Secretaria de Estado da Saúde de São Paulo apresentou o Projeto Urgência-Emergência - Sistema Regional de Referência Hospitalar (SRRH), partindo da constatação de dificuldades do SUS na assistência de urgência-emergência aos doentes, apontando, como causa, o crescente desinteresse dos Hospitais Filantrópicos de perfil regional para realização desse tipo de atendimento. Considerando que a posição desses hospitais sobrecarregava as Unidades de Emergência dos Hospitais Universitários, propôs a criação de um Sistema organizado e regulado, visando ao acesso e atendimento adequado dos cidadãos que sofrem agravos agudos, sejam por causas externas, sejam por doenças agudas ou complicações crônicas preexistentes. Deste modo, estabeleceu os objetivos de organização do Sistema Regional de Referência Hospitalar e seus participantes, regulados pelo gestor regional, integrados a um Sistema de referência e 
Contra-Referência. Apresentou diretriz operacional para implantação de Centrais de Regulação em cada Regional de Saúde.

A Central de Regulação Médica de Botucatu, instalada no Hospital das Clínicas da Faculdade de Medicina, no mesmo bloco onde se situa o Pronto Socorro, iniciou suas atividades em 20 de março de 2000 , seguindo o programa estadual, sob coordenação da DIR - XI. Tem como objetivo a regulação do atendimento médico em casos de urgência-emergência, entendendo-se urgência como necessidade de atendimento médico que pode aguardar um dia ou pouco mais, mas que precisa de garantia de atenção médica dos serviços de pronto atendimento. Emergência é entendida como situações de risco de morte imediata. Como hoje em dia essa distinção é questionável, tem-se usado o termo composto: urgência/emergência. De acordo com Resolução do Conselho Federal de Medicina $\mathrm{N}^{0} 1.451 / 95$, emergência é a constatação médica de condições de agravos à saúde que impliquem em risco iminente de morte ou sofrimento intenso, exigindo, portanto, tratamento médico imediato.

Porém, de acordo com parâmetros médicos seguidos na Central de Regulação Médica, observam-se, na prática, condutas específicas para casos considerados de urgência e casos que, segundo parâmetros médicos, se configuram como emergências.

A região da DIR - XI é dividida em duas sub regiões - Botucatu e Avaré, municípios sede de módulo assistencial e pólo para atendimentos de maior complexidade e de casos de urgência-emergência em nível terciário.

Avaré atende a 18 municípios: Águas de Santa Bárbara, Arandu, Avaré, Barão de Antonina, Coronel Macedo, Cerqueira César, Fartura, Iaras, Itaí, Itaporanga, Manduri, Piraju, Paranapanema, Sarutaiá, Taguaí, Taquarituba, Tejupá e Itaberá.

Botucatu atende a 13 municipios: Anhembi, Areiópolis, Bofete, Botucatu, Conchas, Itatinga, Laranjal Paulista, Pardinho, Pereiras, Porangaba, Pratânea, São Manuel e Torre de Pedra.

A hierarquização dos atendimentos de urgência, segundo orientação da DIR $\mathrm{XI}$ deve ser feita obedecendo-se ao fluxo: Unidade Básica $\Rightarrow$ hospital mais próximo 
$\Rightarrow$ Hospital de Avaré ou HC - FMB. Esse fluxo pode ser visualizado no mapa da região, anexo 2.

As UBSs dos municípios da sub região de Avaré devem encaminhar doentes para a Santa Casa de Avaré, após um primeiro atendimento no hospital mais próximo. Avaré não podendo resolver o problema, encaminha para Botucatu. Com relação ao primeiro atendimento hospitalar, deve-se considerar que:

- Sarutaiá e Tejupá devem encaminhar para Piraju.

- Águas de Santa Bárbara e Iaras devem encaminhar para Cerqueira César.

- Barão de Antonina deve encaminhar para Itaporanga.

- Coronel Macedo deve encaminhar para Taquarituba.

- Os doentes de Taguaí, Itaí, Paranapanema, Manduri e Arandu devem receber atendimento hospitalar em nível secundário em seus próprios municípios.

As UBSs dos municípios da sub região de Botucatu, também devem encaminhar doentes para um primeiro atendimento no hospital mais próximo, que, se necessário, encaminhará para o HC - FMB. Para o primeiro atendimento hospitalar, considerar que:

- Os municípios de São Manuel, Pratânia e Areiópolis devem encaminhar para o Hospital de São Manuel.

- Conchas, Porangaba, Pereiras e Torre de Pedra devem encaminhar para o hospital de Conchas.

- Anhembi, Bofete, Pardinho e Itatinga devem encaminhar ao o hospital da Associação Beneficente dos Hospitais Sorocabana - ABHS.

- Laranjal Paulista deve encaminhar ao hospital de Laranjal Paulista.

- Botucatu deve encaminhar para o hospital da Associação Beneficente dos Hospitais Sorocabana - ABHS, que não podendo resolver o problema encaminha ao $\mathrm{HC}-\mathrm{FMB}$.

Para visualização da rede rodoviária intermunicipal na região da DIR XI é apresentado mapa no Anexo 9. 
A Central de Regulação Médica trabalha mediante contatos telefônicos, com a presença ininterrupta de médicos nas 24 horas, visto que esse tipo de comunicação só pode ser feito entre médicos. São 19 os médicos que atuam nessa central, sendo oito ligados à Faculdade de Medicina, que atendem no periodo diurno nos dias úteis e 11 plantonistas ligados à DIR XI para o trabalho noturno, finais de semana e feriados. Os dados referentes à solicitação são registrados na ficha de urgência/emergência que tem os seguintes itens: Identificação do Solicitante (Data, Hora, Unidade Solicitante, Município, Médico, Número do CRM e Telefone), Identificação do Paciente (Nome, Sexo, Data de nascimento, Município e Endereço), Resumo Clínico do Caso (Queixa e Duração, Exame físico, Exames Complementares, Conduta, Hipótese Diagnóstica e CID), Recurso Solicitado, Justificativa de Solicitação, Resolutividade do Caso (se a solicitação foi atendida ou não, respectivas justificativas, unidade de destino, quarto, leito, médico contatado, CRM, Data e Hora) Recepção do Caso (Paciente chegou? Data, hora, motivo; transporte utilizado; Paciente apresentou-se conforme registro clínico feito na Ficha de Regulação? E Observações).

Os pedidos de atendimento que chegam à Central de Regulação Médica são também provenientes de outras regiões do estado de São Paulo, bem como a Central encaminha doentes para outras regiões. Com maior freqüência são solicitados atendimentos na região de Bauru, Piracicaba, Assis e Sorocaba, principalmente para doentes que necessitam de internação em UTI (adultos e neonatal) devido a escassez de leitos de UTI nesta região de Botucatu. Como o HC - FMB não tem serviço para atendimento de queimados, sempre que necessário são contatadas outras regiões do país que possuem unidade de queimados. A Central de Regulação Médica controla, também, o atendimento de urgências e internações psiquiátricas da região de Botucatu.

A região de Botucatu tem duas UTIs móveis, uma em cada sub-região (Botucatu e Avaré), controladas pela Central de Regulação Médica. Estas unidades móveis são operadas por um motorista e uma equipe habilitada para lidar com equipamentos de UTI, devendo incluir um auxiliar de enfermagem e um médico.

Os critérios adotados para transporte de doentes em UTIs móveis são: 
- Todas as situações que envolvem risco de morte iminente ou perda de função permanente, quando o paciente se encontra em local com limitação de equipe, limitação de recursos diagnósticos e terapêuticos.

- Pacientes com alterações de função respiratória que venham a precisar de ventilação assistida.

- Pacientes com sinais de instabilidade hemodinâmica de qualquer etiologia.

- Pacientes com escore menor ou igual a nove na escala de coma de Glasgow.

- Pacientes com suspeita ou confirmação de trauma raquimedular.

- Pacientes com Traumatismo Crânio Encefálico (TCE) e alteração do nível de consciência.

- Pacientes em uso de drogas vasoativas.

- Pacientes com arritmias ou outras alterações cardiacas necessitando de monitorização contínua.

- Pacientes em pós parada cárdio-respiratória.

- Pacientes politraumatizados.

- Grandes queimados (considerar em menores de dez anos e maiores de 55 anos valor igual a $10 \%$ de superficie corporal queimada e nas outras faixas etárias valor igual ou maior que $20 \%$ como grandes queimados).

- Pacientes obstétricas que se apresentem em trabalho de parto prematuro avançado, com perdas sangüíneas acentuadas, com Doença Hipertensiva Específica da Gravidez (DHEG) avançada e risco de eclâmpsia materna, com Descolamento Prematuro da Placenta (DPP) ou risco de rotura uterina.

- Prematuridade

- Outros critérios dependendo da avaliação do médico regulador.

Apesar deste trabalho centralizado de alocação de atendimentos de urgência, tem sido muito citado pelos profissionais que atuam no HC-FMB o intenso uso de vias alternativas, informalmente chamadas de "terceira via", para atendimento de doentes, mediante contatos pessoais de políticos, ou contatos decorrentes de relações de parentesco, amizade, etc.

A Central de Regulação Médica tem como norma o encaminhamento, ao solicitante, de informações sobre o doente atendido em emergência ou 
encaminhamento do doente para o Hospital Secundário para acompanhamento; essa contra-referência, porém, ainda é problemática porque é muito pouco utilizada.

\subsection{Procedimentos metodológicos}

Para estudar o processo de regionalização do atendimento pelos serviços de saúde da região da DIR XI, optou-se por partir de uma análise da demanda ao Serviço de Urgência/Emergência do hospital universitário, referência na região.

Nesta pesquisa foram combinados procedimentos metodológicos de análise quantitativa e qualitativa, pela necessidade de descrever e interpretar os fenômenos identificados, com vistas a uma avaliação mais abrangente, utilizando-se de abordagem diversificada para interpretação da realidade (MINAYO e SANCHES 1993; TANAKA e MELO 2001).

Deste modo, os dados coletados no Pronto Socorro, mediante entrevistas estruturadas com usuários e questionários aplicados aos médicos que atenderam esses doentes, foram trabalhados quantitativamente. A abordagem qualitativa foi utilizada com uma amostra de usuários, gestores e chefia do Pronto Socorro, os quais foram entrevistados a fim de conhecermos suas representações sobre atendimento e regionalização da assistência à saúde. Foram obedecidas as seguintes etapas:

- Encaminhamento aos Comitês de Ética em Pesquisa da Faculdade de Saúde Pública - USP e da Faculdade de Medicina de Botucatu - UNESP para aprovação do projeto (Anexo 4).

- Apuração, junto à Central de Regulação Médica, dos dados de procedência, diagnóstico, idade, sexo e motivo da solicitação de atendimento caracterizado como urgência/emergência no mês de março de 2002.

- Levantamento de dados sobre demanda ao Pronto Atendimento (PA) e Setor de Emergência (SE) do Pronto Socorro nos anos de 2000 e 2001, junto ao Serviço de Arquivo Médico e Estatística (SAME) do HC - FMB. 
- Obtenção de informações sobre avaliação dos municípios quanto à habilitação na gestão plena de atenção básica ampliada (GPAB-A) feita pela DIR XI e sobre o Plano Diretor de Investimentos - PDI e Plano Diretor de Regionalização - PDR.

- Estabelecimento de período adequado para coleta de dados primários originados de entrevistas estruturadas com pacientes ou responsáveis ou acompanhantes que comparecerem a PA e/ou ao SE do HC - FMB para atendimento.

- Cálculo amostral

Com base nos atendimentos realizados pelo PA e SE do HC - FMB nos anos de 2000 e 2001, estimou-se uma média de 12000 atendimentos dispensados a 8000 pacientes por mês. A amostra deste estudo foi de 410 pacientes entrevistados.

O tamanho amostral foi determinado baseando-se no percentual de pacientes atendidos, utilizando-se $95 \%$ de confiança e uma precisão de $5 \%$. Foram sorteados dias e horários para entrevistas com pacientes que compareceram ao SE, sendo três dias da semana no periodo diurno e três dias da semana no periodo noturno, três sábados, sendo dois no período noturno e um no período diurno e três domingos, sendo dois no período diurno e um no noturno. Também foram sorteados dias e horários para entrevistas com pacientes que comparecerem ao PA, diferentes dos sorteados para entrevistas com pacientes do SE, por razões operacionais. Os sorteios dos dias e horários foram sem repetição, objetivando cobertura de todos os dias da semana e de todos os horários de funcionamento do SE (funcionamento ininterrupto) e do PA (de segunda à sexta-feira, das 7:00 às 19:00 horas). No horário determinado por sorteio, a pesquisadora, uma enfermeira e duas entrevistadoras treinadas permaneceram no SE ou PA. Os doentes ou acompanhantes que compareceram necessitando de atendimento no SE, durante período de três horas e de uma hora no PA, segundo horário de abertura da ficha de atendimento registrado pelo computador, foram convidados a participar do estudo, respondendo às questões propostas, após assinatura do Termo de Consentimento Livre e Esclarecido. Por funcionar ininterruptamente, prestando atendimento durante 720 horas mensais, determinou-se um periodo de três horas em cada dia sorteado para entrevistas no SE. O PA atende durante 12 horas diárias, de segunda à sexta-feira, totalizando 240 horas mensais. Por esta razão, estabeleceu-se um 
período de uma hora em cada dia sorteado para entrevistas naquela unidade. Portanto, durante 36 horas de funcionamento do SE e 12 horas do PA foram entrevistados doentes que lá comparecerem, correspondendo a $5 \%$ da carga horária de funcionamento mensal. No SE foram entrevistados 260 pacientes e no PA 150 , num total de 410 entrevistas.

- Entrevistas com doentes/acompanhantes

As entrevistas com os doentes/acompanhantes foram estruturadas, contendo questões sobre: idade; sexo; escolaridade; ocupação; ramo de atividade econômica; procedência (nos casos de menores de 15 anos as informações sobre escolaridade, ocupação e ramo de atividade econômica referiram-se aos pais ou responsáveis pelos mesmos); Unidade Básica que freqüenta; doença que motivou a procura do PS; hospital de referência do município de origem; passagem pelos serviços de referência e por outros serviços de saúde, incluindo datas e horários; data de chegada para atendimento no PS do HC; tipo de comparecimento (espontâneo ou encaminhado); outros motivos para busca de atendimento no PA ou SE do HC - FMB; meio de transporte utilizado; tempo decorrido entre a saída do local de origem e chegada ao PS, segundo roteiro de entrevista (Anexo 5). As ocupações foram classificadas segundo a Classificação Brasileira de Ocupações - CBO - 2000 - e as atividades econômicas de acordo com a Classificação de Atividades Econômicas - CNAE (CONCLA 2002). As doenças foram classificadas pelo primeiro diagnóstico referido pelo doente, conforme a Classificação Internacional de Doenças (OMS 1997).

- Apresentação de questionário aos médicos que atenderam os pacientes, contendo perguntas sobre hipótese diagnóstica, tipo de atendimento realizado: urgênciaemergência em nível terciário, urgência-emergência em nível secundário, sem necessidade de urgência-emergência, acompanhamento possível em nível primário; conduta tomada pelo médico quanto ao seguimento do doente: atendimento realizado e encaminhamentos efetuados (Anexo 6). Tanto as entrevistas com usuários quanto os questionários respondidos pelos médicos foram analisados mediante uso do programa SAS (versão 6.12). Os resultados serão apresentados em forma de tabelas, contendo freqüências absolutas e relativas dos pacientes para as 
diversas variáveis. Para o estudo das associações entre variáveis foi utilizado o teste do qui-quadrado ao nível de $5 \%$ de significância.

- Entrevistas com gestor regional, gestores municipais, Chefia do Pronto Socorro do Hospital das Clínicas da Faculdade de Medicina de Botucatu e médicos da Central de Regulação Médica, envolvidos neste estudo. Gestores de 13 municípios foram previamente contatados para participação. Os critérios para escolha dos gestores municipais entrevistados foram: interesse em participar do estudo, disponibilidade para a entrevista e consentimento para gravação da entrevista. Foram escolhidos, além do gestor do município sede de módulo e pólo (SMP) e de gestores de dois municípios adscritos ao município SMP, gestores de municípios eqüidistantes, cobrindo a região estudada de um de seus extremos a outro, sendo cinco municípios sedes de módulo (SM) e cinco municípios adscritos aos municípios sedes de módulo, segundo proposta de regionalização em estudo. Foram convidados a participar das entrevistas: o gestor regional, o médico-chefe do Serviço de Urgência/Emergência do HC - FMB e dois médicos da Central de Regulação Médica. Todos concordaram com a participação, tendo sido realizadas 17 entrevistas. As entrevistas iniciaram-se com a apresentação dos objetivos da pesquisa, de alguns dados apurados no estudo da demanda de pacientes ao Serviço de Urgência/Emergência, do levantamento das solicitações de vagas à Central de no mês de março de 2002. Após essas informações, foram apresentadas questões aos entrevistados, conforme roteiro constante do anexo 7 .

Os modelos dos "Termos de Consentimento Livre e Esclarecido" para os Usuários, Médicos do Pronto Socorro, Central de Regulação Médica e Gestores Municipais encontram-se no anexo 8.

\section{- Entrevistas abertas com pacientes}

Julgando necessária uma complementação das informações prestadas pelos doentes, optou-se por entrevistar uma amostra de 30 pacientes que demandaram ao Serviço de Urgência/Emergência do HC - FMB no mês de outubro de 2002, segundo os mesmos critérios de dias e horários adotados nas entrevistas estruturadas, porém utilizando questões abertas, visando a análise qualitativa (Anexo 9). 
Tanto as entrevistas com gestores quanto as realizadas com os pacientes foram gravadas em fitas magnéticas, transcritas, organizando-se os depoimentos de modo a extrair de cada um as idéias centrais e expressões-chave, entendendo que:

1) é necessária uma estratégia metodológica que permita compreender dados subjetivos, a experiência e o conhecimento peculiar de cada um;

2) os gestores municipais de saúde de uma mesma região geográfica, atuando no seu cotidiano interagem, dialeticamente, com o município, com a região e sua população, da qual também fazem parte, gerando o meio ideológico e sendo gerados por esse meio, desenvolvendo opiniões, explicações e argumentos;

3) a estratégia metodológica deve representar a coletividade dos gestores e de usuários, não reduzindo suas falas, nem somando trechos de falas semelhantes, mas reunindo trechos diferentes das falas de cada entrevistado, compondo um único discurso, o discurso do social.

Optou-se por adotar a abordagem metodológica desenvolvida por LEFÈVRE et al. (2000) que permite a construção do discurso do sujeito coletivo, a partir da identificação das idéias centrais e expressões-chave, melhor visualizando a representação social de atores sociais com quesitos básicos em comum: a) usuários dos serviços de saúde da região; b) gestores municipais de saúde de uma mesma região.

Segundo esses autores, o Discurso do Sujeito Coletivo

"é composto por aquilo que um dado sujeito individual falou e também por aquilo que poderia ter falado e que seu companheiro de coletividade atualizou por ele já que o pressuposto sociológico de base é que o Discurso do Sujeito Coletivo é a expressão simbólica do campo a que ambos pertencem e da posição que ocupam dentro deste campo ou de uma cultura organizacional". (LEFÈVRE et al. 2000, p.30).

“... O pensar das pessoas sobre o tema $X$ não é o equivalente ao conteúdo que eventualmente verbalizam nas entrevistas, mas além e mais do que isso é aquilo que podem pensar, ou seja, o que está no horizonte de pensamento de uma dada cultura. Isto significa, por exemplo, que o pensamento de um dado indivíduo pode incluir também aquilo que outros indivíduos 
socialmente equivalentes verbalizaram por ele"

(LEFÈVRE et al. 2000, p.34).

As perguntas apresentadas aos entrevistados geraram práticas discursivas, ou seja, modos pelos quais estes indivíduos produzem sentidos e se posicionam em relação às suas atividades cotidianas. De acordo com SPINK e MEDRADO (2000), a produção de sentidos no cotidiano decorre dos repertórios interpretativos de que se dispõe, os quais são histórica e culturalmente constituídos e se processam no contexto da ação social. Também a produção do conhecimento, conforme esses autores, pode ser construída num tempo e espaço específicos de uma realidade intersubjetiva, que inclui a participação do pesquisador, numa perspectiva de que o conhecimento se constrói coletivamente, mediante "interanimação dialógica".

Adotando essa postura, buscou-se complementar algumas informações prestadas pelos usuários para melhor compreensão da realidade. Quanto às entrevistas com gestores, o propósito foi o de analisar os processos pelos quais compreendem e explicam o atual sistema de saúde e seus princípios de organização, regionalização e hierarquização dos serviços.

$\mathrm{Na}$ apresentação dos Discursos do Sujeito Coletivo (DSC) dos gestores foram omitidas palavras ou frases que possibilitassem a identificação dos entrevistados.

$\mathrm{Na}$ construção das tabelas, quando foi necessário, os municípios foram agrupados segundo o Plano Diretor de Regionalização da DIR XI, porém, como o município de Itaberá, no periodo da realização das entrevistas não pertencia à região do estudo, todas as vezes em que este apareceu foi registrado como "Outras regiões". 
Resultadose Discussão

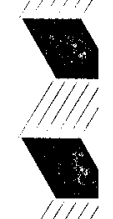




\section{Resultados e discussão}

\subsection{Central de Regulação Médica}

Os dados levantados junto à Central de Regulação Médica no mês de março de 2002 foram organizados em duas tabelas, apresentadas a seguir.

$\mathrm{Na}$ Tabela 1 verifica-se que, embora em números absolutos a maior parte das solicitações à Central de Regulação Médica, também conhecida como Central de Regulação de Vagas, ocorrida no mês de março de 2002, tenha procedido do município de Botucatu, que tem o maior número de habitantes, quando realizou-se a análise proporcional este passou a ocupar o $12^{\circ}$ lugar.

Em Botucatu, além do HC - FMB, o único hospital conveniado com o SUS é o Hospital da Associação Beneficente dos Hospitais Sorocabana, que vem tendo dificuldades financeiras e desinteresse de diversas ordens para realizar internações pelo SUS. Logo, a alternativa que resta ao municipio é a solicitação à Central de Regulação Médica de providências para os atendimentos mais complexos.

Proporcionalmente, quem fez mais solicitações à Central de Regulação Médica foram os municípios de Pardinho, Itatinga, Cerqueira César e Conchas. Os dois primeiros são próximos à Botucatu e os dois últimos mais distantes.

As solicitações à Central de Regulação Médica com justificativas de falta de recursos e de especialistas corresponderam a $77,3 \%$ do total.

Os recursos solicitados pelos municípios à Central de Regulação Médica estão discriminados na tabela 2 . 
Tabela 1 - Distribuição das solicitações à Central de Regulação Médica da DIR XI - Botucatu, segundo município solicitante e justificativas de solicitação, no período de 01/03/2002 a 31/03/2002

\begin{tabular}{|c|c|c|c|c|c|c|c|c|c|c|c|c|c|}
\hline \multirow{3}{*}{ Município } & \multicolumn{13}{|c|}{ Justificativas } \\
\hline & \multicolumn{2}{|c|}{$\begin{array}{c}\text { Falta } \\
\text { de } \\
\text { recursos }\end{array}$} & \multicolumn{2}{|c|}{$\begin{array}{c}\text { Falta } \\
\text { de } \\
\text { vagas }\end{array}$} & \multicolumn{2}{|c|}{$\begin{array}{l}\text { Hospital não } \\
\text { capacitado }\end{array}$} & \multicolumn{2}{|c|}{$\begin{array}{l}\text { Médico ausente ou } \\
\text { não localizado }\end{array}$} & \multicolumn{2}{|c|}{$\begin{array}{c}\text { Não há } \\
\text { especialista }\end{array}$} & \multicolumn{2}{|c|}{$\begin{array}{l}\text { Paciente acompa- } \\
\text { nhado na referência }\end{array}$} & \multirow[t]{2}{*}{ Total } \\
\hline & $\mathrm{N}$ & $\%$ & $\mathrm{~N}$ & $\%$ & $\mathrm{~N}$ & $\%$ & $\mathrm{~N}$ & $\%$ & $\mathrm{~N}$ & $\%$ & $\mathrm{~N}$ & $\%$ & \\
\hline Botucatu & 15 & 15,5 & 20 & 20,6 & 57 & 58,8 & - & - & 4 & 4,1 & 1 & 1,0 & $97(22,6)$ \\
\hline Anhembi & 3 & 50,0 & - & - & - & - & - & - & 3 & 50,0 & - & - & $6(1,4)$ \\
\hline Bofete & 1 & 9,1 & - & - & - & - & - & - & 10 & 90,9 & $\therefore$ & - & $11(2,6)$ \\
\hline Pardinho & - & - & - & - & - & - & - & - & 12 & 100,0 & - & - & $12(2,8)$ \\
\hline São Manuel & 24 & 55,8 & - & - & 1 & 2,3 & 1 & 2,3 & 16 & 37,2 & 1 & 2,3 & $43(10,0)$ \\
\hline Areiópolis & 6 & 66,6 & - & - & - & - & - & - & 3 & 33,3 & - & - & $9(2,1)$ \\
\hline Itatinga & 5 & 14,7 & - & - & - & - & - & - & 29 & 85,3 & - & - & $34(7,9)$ \\
\hline Conchas & 12 & 42,8 & $=$ & - & - & - & - & - & 16 & 57,1 & - & - & $28(6,5)$ \\
\hline Porangaba & 7 & 70,0 & - & - & - & - & $=$ & - & 3 & 30,0 & - & - & $10(2,3)$ \\
\hline Laranjal Pta. & 6 & 50,0 & - & - & - & - & - & - & 6 & 50,0 & - & - & $12(2,8)$ \\
\hline Avaré & 18 & 56,2 & 5 & 15,6 & 3 & 9,4 & 1 & 3,1 & 5 & 15,6 & - & - & $32(7,5)$ \\
\hline Arandu & 2 & 28,6 & - & - & & - & - & - & 5 & 71,4 & - & - & $7(1,6)$ \\
\hline Cerqueira Cesar & 6 & 20,6 & - & - & - & - & 1 & 3,4 & 22 & 75,9 & - & - & $29(6,8)$ \\
\hline Manduri & 5 & 38,5 & - & - & - & - & 1 & 7,7 & 7 & 53,8 & - & - & $13(3,0)$ \\
\hline Águas de Santa Bárbara & - & - & - & - & - & - & - & - & 1 & 100,0 & $=$ & - & $1(0,2)$ \\
\hline Paranapanema & 9 & 50,0 & - & - & - & - & - & - & 9 & 50,0 & - & - & $18(4,2)$ \\
\hline Itai & 5 & 38,5 & - & - & 1 & 7,7 & - & - & 7 & 53,8 & - & - & $13(3,0)$ \\
\hline Taguai & - & - & - & - & - & - & - & - & 1 & 100,0 & - & - & $1(0,2)$ \\
\hline Pirajú & 13 & 61,9 & - & - & $+8-$ & - & 1 & 4,8 & 7 & 33,3 & - & - & $21(4,9)$ \\
\hline Fartura & 2 & 33,3 & - & - & 2 & 33,3 & - & - & 2 & 33,3 & - & - & $6(1,4)$ \\
\hline Itaporanga & 7 & 87,5 & - & - & - & - & - & - & 1 & 12,5 & - & - & $8(1,9)$ \\
\hline Taquarituba & 8 & 44,4 & 1 & 5,6 & - & - & - & - & 9 & 50,0 & - & - & $18(4,2)$ \\
\hline Total & 154 & $(35,9)$ & 26 & $(6,1)$ & 64 & $(14,9)$ & 5 & $(1,1)$ & 178 & $(41,5)$ & 2 & $(2,5)$ & $429(100,0)$ \\
\hline
\end{tabular}


Tabela 2 - Distribuição das solicitações à Central de Regulação Médica da DIR XI - Botucatu, segundo município solicitante e recurso solicitado, no período de 01/03/2002 a 31/03/2002

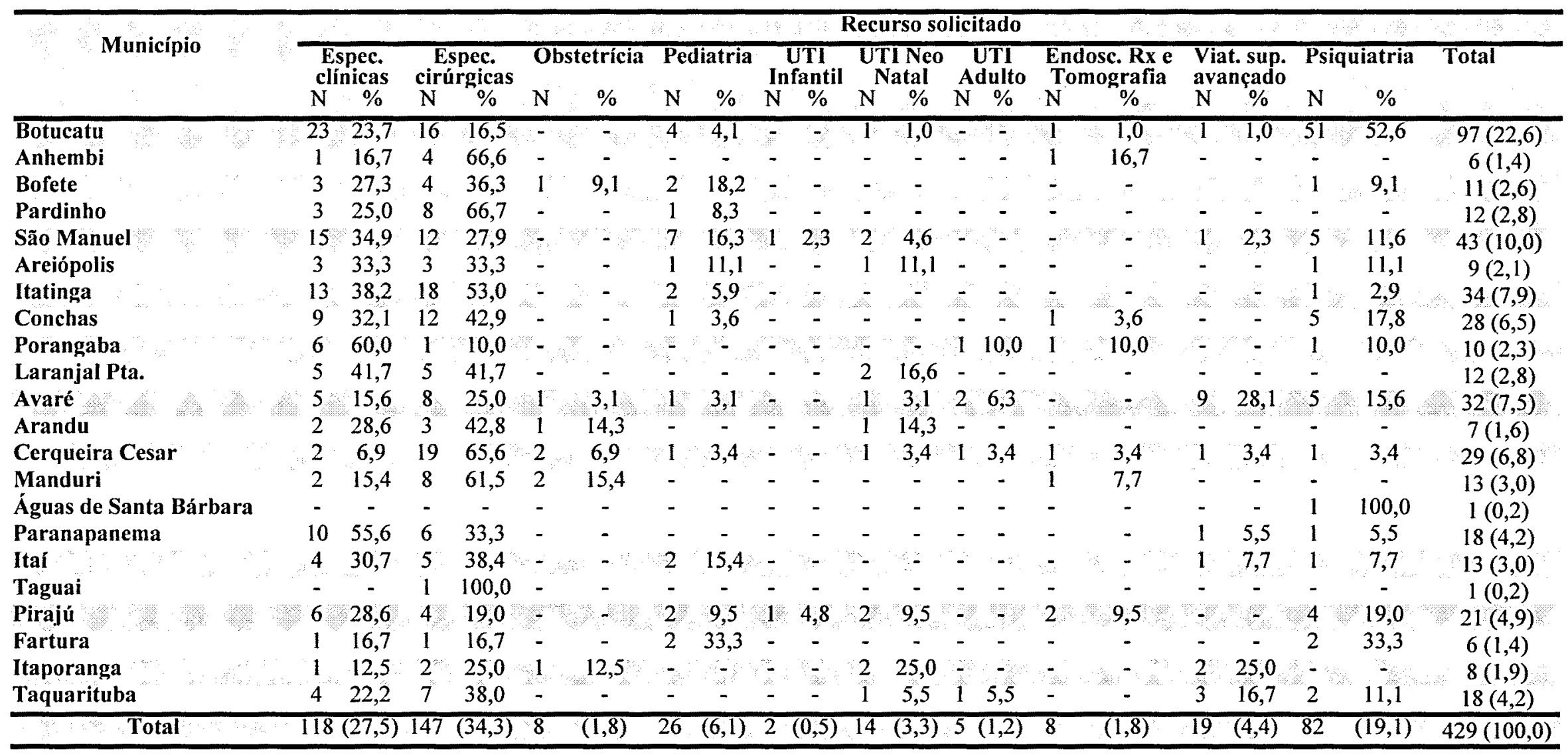


Nesta segunda tabela observa-se que os recursos mais solicitados foram: especialidades clínicas, especialidades cirúrgicas e psiquiatria.

Sobre a demanda de solicitações à Central de Regulação Médica, os Gestores entrevistados assim se manifestaram, conforme discurso do Sujeito Coletivo apresentado a seguir, em resposta à pergunta:

Foi observada grande demanda de solicitações à Central de Regulação Médica com justificativas de falta de médicos e de materiais ou equipamentos para atendimento no próprio município. O que você pode dizer sobre isto?

\section{Quadro Síntese das Idéias Centrais}

\begin{tabular}{|l|l|}
\hline A & A CRV é uma tentativa de organização do sistema. \\
\hline B & A negligência é um grave problema. \\
\hline C & A UNESP inibe a responsabilidade dos municípios pelos atendimentos. \\
\hline D & O equipamento básico todo mundo tem que ter. \\
\hline E & Os especialistas vêm de fora, fazem o atendimento e vão embora. \\
\hline F & O município só faz solicitações à CRV para o atendimento de casos graves. \\
\hline G & Faltam recursos e especialistas no local de referência secundária. \\
\hline H & É preferível pecar por excesso e encaminhar para a UNESP. \\
\hline
\end{tabular}

\section{A - A CRV é uma tentativa de organização do sistema (G1, G2).}

Acho que num primeiro momento tinha um sistema caótico de demanda espontânea dentro da Unesp e os municipios sempre encaminhavam para lá, independente do que estava ocorrendo. Quer dizer, isso já era uma coisa cultural. Ai, de repente, coloca-se alguma coisa no lugar... Alguma coisa que vai tentar organizar isso. E organizar no seguinte sentido: para encaminhar tem que passar por essa central de regulação, quer dizer, começa um processo todo de rediscussão do caso. Se aquele caso realmente tem que ir para a Unesp, ou se ele pode ser resolvido no nivel que ele está, ou tem um outro hospital que ele pode ser encaminhado. Para alguns municipios é muito mais tranqüilo pegar o paciente e botar na ambulância e levar ao hospital do que ele tentar resolver o problema dele ali, naquele municipio. Eu conheço dois períodos: o periodo antes da valorização da AIH, e após a valorização da AIH. O que eu tenho observado é o seguinte, que depois que as AIHs, desses 
recursos de qualquer ordem... os mais raros foram valorizadas, que o número de encaminhamentos diminuiu bastante, em ortopedia, então, serviços que não tinham ortopedia passaram a fazê-lo, serviços que não atendiam cirurgia vascular, passaram a fazer.

\section{B - A negligência é um grave problema (G1, G2, G8).}

E eu acho que mais grave é a negligência. A gente não pode esquecer que tem colegas que dão plantão e são negligentes mesmo, eles não querem ter o paciente reclamando no ouvido deles. Então, é mais fácil pegar o paciente, pôr numa ambulância e mandar para o hospital e ai se livra daquele paciente, do que ficar o dia todo monitorando a pressão, monitorando o batimento fetal, essas coisas todas, quer dizer, se livra do problema.

Do mesmo modo, tentando transferir o paciente do municipio A para o municipio $B$, em que o municipio $B$ é o que receberia, ele diz o seguinte: Bom, ele está querendo encaminhar, mas se o paciente fosse particular ou fosse conveniado, ele aceitaria. Ai eu penso o seguinte, o que dificulta a referência e contra-referência dos pacientes é a questão financeira, se o paciente é particular, geralmente ele fica no municipio de origem, se ele é paciente SUS o municipio tenta encaminhar.

Muitos devem estar indo porque o médico deve ter recusado a atender e o plantonista solicilou a vaga para estar encaminhando. Isso a gente não pode negar.

\section{C - A UNESP inibe a responsabilidade dos municípios pelos atendimentos (G3, G4, G6, G11).}

Então imagine o seguinte, o paciente está numa cidade ao redor ou aqui mesmo. Digamos que não tivesse a Unesp e faltou médico, esse paciente morre, o que vai acontecer com o médico que faltou, com o prefeito que não deu, com o secretário? Então, o paciente vai para a UNESP, porque ela funciona 24 horas, tem todos os especialistas, etc e tal. Então, na minha opinião, é um fator que eu chamo de inibitório. A faculdade de medicina, ela inibe a responsabilização.

Em um fim de semana, os três obstetras foram de férias. Um de férias outro congresso, outro saiu. Aliás, saiu porque os outros dois sairam. Bom, como é que um municipio fica sem três obstetras num fim de semana? Não dá para admitir. Isso é 
um problema do gestor, não é um problema do médico. O gestor que tem que resolver porque agora a cultura é a seguinte, não podemos ficar sem médicos em obstetricia, em cirurgia, em clínica e em pediatria. Ou eu posso até ficar, desde que o município vizinho atenda, então faz um rodizio com o município vizinho.

Tem problemas com equipamentos também, mas existe uma acomodação em transferir para a Unesp os problemas. Então, assim, o que a Unesp tem a ver que o ginecologista e o obstetra não estão de plantão? Não tem nada com isso. Problema do diretor clínico, não é um problema da Unesp, não é da Central de Regulação. Que ocorra alguma coisa de vez em quando, isso é uma exceção, agora a regra é que de sexta-feira todo mundo vai para a Unesp ou para a Santa Casa de Avaré, que é a referência nossa formal estabelecida no secundário também, então, é uma situação também de acomodação. Agora, a partir do momento que tem um hospital e que faz um convênio que diz que vai fazer aquelas coisas, tem que fazer, e a central, mesmo Unesp, mesmo Santa Casa em Avaré, tem realmente que discutir, tem que bater de frente e devolver aquele paciente que não deveria estar lá, não tem que receber por esse paciente, ela não tem que assumir uma responsabilidade que não é dela. O que é secundário e o que é terciário, que está hierarquizado e está regionalizado sim, mas porque o médico faltou, porque o plantão, não sei o quê, o prefeito não pagou o plantão e porque o hospital... Isso não é problema dessas referências. Então, muita coisa acaba dando de demanda para a central, sem ser o papel dela resolver, aí joga na mão do outro profissional, só que atrás dessa dificuldade tem o paciente, ai você tem que dar conta do paciente, porque o paciente não tem nada a ver com isso. Na CIR, que é uma reunião dos secretários municipais que é mensal, isso é discutido com os secretários, para que se organizem para que detectem o problema, para ver quem é que está fazendo, quem é o plantonista que mais apronta, porque também a gente vai identificando, no decorrer do tempo, que quando determinado profissional está em determinado lugar a Central fica cheia, então tudo isso a gente tem discutido, melhora um pouco, dali a pouco começa tudo de novo, é uma permanente discussão, porque assim, tudo o que puder empurrar para o outro fazer, ainda é a melhor regra.

Garanto para você que das 40 consultas e das 44 internações, não precisariam estar lá todas, mas como a gente também tem o sistema da Central de Regulação de 
Vagas, como a gente tem os casos de traumas, AVCs, os partos mais graves, a gente solicita o leito para poder estar encaminhando os casos, mas garanto para você que em torno de $50 \%$ poderiam estar sendo resolvidos aqui.

\section{D - O equipamento básico todo mundo tem que ter. (G3, G11).}

O ATLS, que é o "must" aí na questão da urgência-emergência, que é um curso extremamente caro, é muito interessante, porque ele ensina uma coisa: você atende qualquer paciente na emergência com esteto e com esfigmo. A tomografia, a ressonância, são coisas para um segundo momento, um segundo atendimento da urgência. Então acho que tem uma outra coisa, acho também, que nem lodos os hospitais devem ter todos os equipamentos. Mas o equipamento básico para um atendimento inicial todo mundo tem que ter, evidentemente. Agora, acho dificil que alguém seja encaminhado na emergência porque faltou uma tomo. A não ser um caso muito especifico, um trauma crânio-encefálico, um politraumatizado que já foi equilibrado e estabilizado. Mas, de uma maneira geral, é falta de politica mesmo. E, quando se fala na atenção básica, ai sim eu acho que tem que ter um investimento maior e nós podemos melhorar a situação. Agora, quando se fala de uma UTIneonatal, eu já não vejo nem pela UTI, porque além de eu não ter o recurso técnico, que são os equipamentos da UTI de verdade, eu não tenho profissional também. Então, qual é nossa briga com a região? $\dot{E}$ desafogar a Unesp com aquelas coisas banais, de pacientes que estão lá há 4, 5, 6 anos e talvez a gente até possa assumir esses casos numa boa triagem, para realmente poder usar a Unesp nesses casos quando for necessário.

\section{E - Os especialistas vêm de fora, fazem o atendimento e vão embora. (G6, G7).}

(Quanto às solicitações à CRV) Inclusive, muito do que temos, cárdio nós temos especialista daqui do nosso municipio, clínica médica temos, gastro clínica temos, neuro temos, mas você poderá observar pelos dias da semana, que deve ocorrer aos fins de semana, quando nosso médico já não está em nossa cidade, na grande parte. Segundo, nós implantamos desde o ano passado, a partir da sexta até a segunda, o plantão com os residentes da própria Unesp. Muitas vezes, eles acham mais fácil estar encaminhando porque eles acham mais rápido lá na Unesp, do que ficar 
chamando o profissional especialista da nossa cidade, do que ficar chamando o pediatra, ele prefere ligar para o colega da Unesp, então ele acha que vai ter mais facilidade para estar encaminhando esse paciente. E eu acredito que esteja nesses moldes. Existem os especialistas, só que eles vêm uma, duas vezes por semana somente atender. Eles não vêm todo dia, eles não são da cidade. Eles vêm de fora, fazem o atendimento e vão embora.

F - O município só faz solicitações à CRV para o atendimento de casos graves (G7, G9, G17).

(Quanto às 26 internações na UNESP de pessoas do município no mês de março) devem ter acontecido casos graves para serem internados lá. Porque normalmente, se é um caso que eles, a própria Unesp, acha que não é deles, eles acabam retornando o paciente para cá, né? Então, se eles permaneceram internados são casos, realmente, que assim, que você sabe. Tem mês que acontecem casos mais graves, com uma certa freqüência, a gente teve assim, determinados acidentes de carro aqui, por a gente ser próximo à Castelo Branco, ou às outras rodovias, então a gente teve acidentes.

Tem pacientes que apresentam quadros mais importantes, uma colecistite, pneumonia, algum acidente vascular cerebral, crises hipertensivas que não se resolvem assim facilmente, esses nós encaminhamos para o municipio que é nossa referência secundária, que solicita à Central de Vagas.

\section{G - Faltam recursos e especialistas no local de referência secundária (G10, G11, G12, G13, G14, G15, G16, G17).}

$\dot{E}$ impressionante como nós temos bastante casos de neuro, de encaminhamentos. $E$ a UTI, que é esse grande problema e a ortopedia que é o nosso tendão de Aquiles. $O$ problema maior é a ortopedia. Nós conversamos com os neurocirurgiões, fizemos um convênio, montamos uma equipe, ainda estamos brigando muito para credenciar a UTI a nivel 2, com outros serviços de neurocirurgia e ortopedia a nivel 2, como uma maneira até de estimular essa vinda ao nosso município, para o nosso municipio querer aceitar outros pacientes. Então, isso realmente é dificil. A Santa 
Casa hoje fecha as portas para esses municípios, mesmo porque assim, se não tiver vaga para mim... Uma vez eu precisava urgentemente atender um paciente, paciente grave que estava no pronto socorro, e precisava de UTI, e ligaram dizendo: - Olha, não tem, não tem, não tem. - Como não tem? A Gente paga diária, vamos ligar lá, são 5 leitos. Os 5 leitos estavam ocupados com pacientes de fora. Eu falei: - Ah, mas isso vocês vão ter que abrir, porque essa conta eu não pago, ou eu corto o convênio com vocês.

O ortopedista, eu tenho ortopedista no municipio, porém ele é limitado a trabalhar porque eu não consegui até agora contratar um anestesista. É complicado para um municipio pequeno contratar um anestesista. Faz 8 meses que eu estou atrás de um anestesista para a gente fazer algumas cirurgias aqui e outra coisa é a parte de ortopedia. A parte de ortopedia o municipio tem o médico, mas não tem os recursos para fazer uma cirurgia, alguma coisa nesse sentido. Então acho que realmente nós temos falhas em algumas áreas como eu falei, anestesista, neuro, são profissionais que dificilmente vêm trabalhar num centro pequeno..., a gente faz o encaminhamento justamente por isso, porque nós não temos condições, até temos condições financeiras, de ter o profissional, mas não temos o profissional. Às vezes a gente tem a especialidade na rede, mas não tem no hospital, como é o caso de neuro, de psiquiatria, vascular, nem na rede a gente tem, MI também, nem na rede tem, mas tem alguns casos que a gente tem na rede e não tem no hospital. Agora a gente começou a acertar, porque o hospital se propôs e a prefeitura está ajudando financeiramente a pagar plantões para algumas das especialidades no caso das urgências. Se você for verificar hoje, vai ver que nós encaminhamos muito problema de cardiologia, principalmente marca-passo, são sempre encaminhados esses pacientes.

Psiquiatria, esse é um problema, porque nós não temos e não está fácil na rede básica onde nós somos referenciados. Se você ligar no ARE [Núcleo de Gestão Assistencial - NGA] hoje vai ver a dificuldade que é agendar uma consulta. A pessoa está em surto aqui, o que nós temos que fazer? Pedir para a $C R V$, porque se ligar no ARE eles vão falar: - se for urgente é a Unesp. Mandam falar lá no Pronto Socorro e a gente sabe que não é o caminho, então vamos ligar para a Central de Vagas. 


\section{H-É preferível pecar por excesso e encaminhar para a UNESP (G11, G16).}

A gente acredita que este municipio tem condições plenas de socorrer um prematuro desse porte. Menos do que isso eu acredito que não, porque ela se torna até alto risco, mas de 35 semanas eu acredito que dá para fazer, mas o que acontece? Os pediatras aqui acham que não, que é melhor não arriscar. Até eu acho que seja por excesso de zelo, não acredito que seja por má vontade, então, com isso eles encaminham para lá dizendo que aqui não tem recursos para isso.

Obstetricia, eu prefiro pecar por excesso, isso eu tenho falado a todos os profissionais médicos em todas as reuniões que eu faço. - Tem suspeita de gestação de alto risco? Encaminhe. Porque eu sei o que eu estou pagando hoje por uma falta de atenção um pouquinho maior do profissional médico.

Os entrevistados apontam aspectos positivos da Central de Regulação Médica, destacando seu papel na organização do sistema de atenção às urgências/emergências. Aliás, esta é a finalidade da Central de Regulação Médica, que tem responsabilidades na coordenação dos meios disponíveis para os atendimentos de urgência/emergência, indicando e acionando os serviços receptores, garantindo que cada paciente receba atendimento compatível com sua necessidade.

Porém, são apontados problemas ligados ao jogo de interesses, tais como, o de municípios darem preferências para o atendimento de casos mais lucrativos, solicitando providências da Central de Regulação Médica para os não lucrativos ou mais dispendiosos.

São comentadas, também, as solicitações à Central de Regulação Médica para atendimentos de pacientes que poderiam ter seus problemas resolvidos no próprio município, mas que devido a ausência de médicos no serviço ou no município, principalmente nos finais de semana, necessitam ser encaminhados para outras cidades. Outra distorção apontada decorre da atuação de residentes da UNESP em alguns municípios e a tendência deles encaminharem para a UNESP por acharem mais fácil.

Neste estudo foi possível constatar que os municípios menores não têm recursos para manter médicos durante todos os períodos e todos os dias. Vários municípios não têm médicos em todas as chamadas especialidades gerais (Clínico 
Geral, Pediatra, Ginecologista-Obstetra e Cirurgião Geral) especialmente nos feriados e finais de semana. Isto implica em encaminhamentos para outros municípios com mais recursos, muitas vezes cidades de outras regiões que não são as sedes de módulo às quais se vinculam, conforme as diretrizes da regionalização, ou a busca de uma saída junto à Central de Regulação Médica. Há situações em que o municipio sede de módulo, que deveria e poderia dar o atendimento requerido, por problemas de gestão, como o apontado, em que os três obstetras se ausentaram do município ao mesmo tempo, solicita à Central de Regulação Médica providências para viabilizar o encaminhamento do doente. Estas ocorrências parecem mesmo indicar certo comodismo de alguns gestores municipais, talvez explicado pelo fato de existirem outras alternativas ou mesmo uma "retaguarda confiável", sem atentarem para as implicações que isso acarreta à Central de Regulação Médica e aos serviços receptores de maior complexidade da região.

Un grupo de gestores também entende que os municípios deveriam ser mais bem preparados quanto a pessoal e equipamentos para um primeiro atendimento aos casos de urgência/emergência. Para isso, os municípios deveriam ter serviços funcionando ininterruptamente, considerando-se que a noção de urgência está vinculada ao tempo - trata-se de um paciente que não pode esperar.

Outra questão que surge refere-se aos especialistas necessários para os atendimentos. Os municípios ressentem-se principalmente da falta de neurologistas, ortopedistas, cirurgiões vasculares, anestesistas e psiquiatras. A maioria dos municípios conta com o trabalho de clínicos gerais, pediatras, gineco-obstetras e cirurgiões gerais, porém estes têm desempenhado, com freqüência, uma função mais triadora. Essa diminuição da capacidade resolutiva das especialidades-raízes foi identificada por CAMPOS et al. 1997, segundo os quais tal situação leva ao acréscimo dos encaminhamentos e à realização de exames complementares injustificados. Em vista disto, os autores propõem a divisão da área de competência de cada especialidade em dois espaços denominados "campo de competência" - que inclui os principais saberes da especialidade, fazendo intersecção com outras áreas com limites e contornos menos precisos - e "núcleo de competência" - com atribuições exclusivas da especialidade e limites mais definidos. Deste modo, poderse-ia assegurar a capacidade resolutiva das especialidades gerais. Esta é, portanto, 
uma questão política ligada à participação dos especialistas no SUS, que deverá ter reflexos no sistema formador.

Diversos gestores sugerem a contratação de especialistas para o atendimento de usuários de três ou quatro municípios, de modo a atender suas necessidades e viabilizar a permanência do especialista na micro-região. Esta pactuação entre os municípios é exatamente o que se espera do processo de regionalização, mas parece haver entre os gestores uma espera de determinações vindas de esferas superiores, como se os municípios não tivessem autonomia para estabelecer seus acordos.

A alegação de falta de vagas para o atendimento em determinadas especialidades médicas tem sido feita até para casos de urgência/emergência. Destaca-se aqui que a Central de Regulação Médica deve considerar "o conceito de que nas emergências não existe número fechado de leitos ou capacidade limite a priori" (BRASIL 1999).

Ainda sobre a Central de Regulação Médica, outra questão apresentada aos gestores foi:

O que você está achando das condutas tomadas pela Central de Regulação Médica no atendimento às solicitações dos municípios?

\section{Quadro Síntese das Idéias Centrais}

\begin{tabular}{|c|c|}
\hline A & A falta de recursos e os casos mais onerosos geram demanda à UNESP. \\
\hline B & Existe grande tensão entre os prestadores de assistência médica da região. \\
\hline C & Há quem burle todas as regras. \\
\hline D & A UNESP deveria ser regional. \\
\hline $\mathbf{E}$ & $\begin{array}{l}\text { A CRV tem problemas: demora para decidir, não tem real controle sobre } \\
\text { sua demanda e às vezes encaminha pacientes sem considerar a falta de } \\
\text { recursos do hospital. }\end{array}$ \\
\hline $\mathbf{F}$ & A CRV é um avanço e pode avançar mais. \\
\hline $\mathbf{G}$ & A CRV precisa ser mais orientadora. \\
\hline
\end{tabular}


A - A falta de recursos e os casos mais onerosos geram demanda à UNESP (G1).

Tem desde aquele municipio onde não tem realmente o recurso, então tem que procurar em outro lugar e tem aqueles municipios onde tem recursos e os municipios simplesmente se negam a atender. Por quê? Porque dependendo da urgência e emergência são casos caros, vai onerar muito o hospital. Aí tem a questão do teto financeiro do hospital, tem a questão de leito de UTI, que na nossa região é escasso. Aqui na nossa região, o único lugar que tem leitos de UTI é no Hospital das Clinicas mesmo. E algumas especialidades, tem locais assim, tem especialidade $e$ a especialidade simplesmente se nega a atender a urgência, porque sabe que aquela urgência vai demandar muito o serviço, vai onerar. Um exemplo prático disso são os casos de trauma craniano, esses casos, geralmente eles acabam indo para a Unesp, porque a região que, em tese, poderia atender que seria Avaré, não atende, simplesmente se nega a atender.

B - Existe grande tensão entre os prestadores de assistência médica na região. (G2, G10, G12).

Existe grande tensão entre os prestadores de assistência médica na região e é meio a Lei do Simpson, "Isso não é comigo e já estava assim quando eu cheguei". As pessoas que ocupam cargos de gerência, elas tentam se livrar de parte da responsabilidade que lhes seria atribuida, tentando passar a responsabilidade da assistência de seu município para um outro município que eles acham que tem mais recurso. E esse outro municipio sempre reclama.

Acho que é o grande conflito que tem lá dentro, você tem um paciente que precisa de uma urgência e precisa de leito e na prática às vezes acaba não tendo leito, então tem que remeter esse paciente para outra regional, outra região do estado ou mesmo para a capital. Então isso aí acaba sendo complicado.

O que a gente percebe é que muitas vezes é profissional com profissional. Ai quebra aquele pau, fica aquela coisa, liga para um, liga para outro... A idéia da Central de Regulação eu acho perfeita porque é uma maneira de você regular, mas ainda tem profissionais, que enganam a Central de Regulação. Nós pegamos uma transferência de um politraumatizado, faz pouco tempo, um menino de 13 anos, que sofreu um 
acidente na cidade e não tinha recursos, mas a informação era de que a criança estava bem era só para fazer uma tomografia. A criança veio chocada, sem acesso venoso, sem médico, com um auxiliar de enfermagem, numa ambulância comum. Quando ele chegou aqui nós descobrimos que o médico nos enganou, que não tinha profissional no pronto socorro deles. Ai foi o maior rebú. Liga para a central fala que aconteceu isso, isso, isso. Põe no relatório, manda para não sei quem, não sei que lá.

Eu acho que até agora, se teve algum problema foi em decorrência do nosso médico. Nosso médico que às vezes quer processar uma emergência que às vezes não é lão emergência, uma urgência que não é tão urgência, e às vezes isso que ocorre. Antes se encaminhava sem consultar a Central de Vagas, hoje a gente normatizou que não sai nenhum paciente sem a Central de Vagas dar o OK para estar saindo.

\section{C- Há quem burle todas as regras (G4, G5, G16).}

Têm ocorrido alguns problemas que são pontuais, até por conta mesmo do município de Botucatu burlar todas as regras. Então, quando a Central diz que não consegue receber determinado paciente, que é caracterizado de urgência e emergência, que está aguardando vaga, os municípios se revoltam porque Botucatu não respeita isso, ele põe o paciente na porta do Pronto Socorro.

Botucatu, não tem tido problemas com a Central de Vagas, ela é que tem tido problemas com Botucatu. A reclamação da Central é que o pessoal encaminha sem passar pela Central de Vagas. Então, por exemplo, das unidades o pessoal manda diretamente para o Pronto Socorro e não se comunica com a Central de Vagas. E um dos argumentos do pessoal é o seguinte, se entrar pela Central de Vagas, ela vai mandar para a triagem da especialidade e não vai entrar nunca e esse é um caso que precisa, não é assim, uma emergência, mas é uma urgência, precisa de uma consulta mais ou menos logo. Então manda para o Pronto Socorro porque via Pronto Socorro, digamos assim, é uma válvula de escape que o pessoal achou para o sistema que não da conta da demanda de especialidades.

Poderia ser diferente sim. Com certeza, talvez até 50\% desse número poderia ser atendido aqui (em nível local). Mas a pessoa bate o pé, dá um jeito e de um jeito ou de outro acaba indo. Isso porque ela não foi atendida aqui? Não, ela pode até ter 
sido atendida aqui, mas ai ela fala que não foi bem atendida que não teve seu problema resolvido, por isso que ela foi para lá. Muitos vão sem passar por aqui mesmo, eles vão porque querem ser atendidos lá.

\section{D - A UNESP deveria ser regional (G8, G13).}

O que a gente vê muito é que a Unesp eu acho que deveria ser Regional. Eu acho que ela deveria atender mais a região de Botucatu. E não atender pacientes que vêm lá do Paraná, do Mato Grosso, que às vezes acaba tirando dos nossos pacientes daqui da região, porque chega lá não tem vaga, não tem vaga. Então, a Central, eu acho que piorou nesse sentido, eles não têm idéia como é aqui, o que a gente sofre por tentar salvar a vida do paciente. Tem paciente que às vezes saem, familias, familiares que às vezes saem, fazem o boletim de ocorrência, porque acham que a gente é que não quer mandar o paciente para a Unesp. Por mais que a gente explique que não depende da gente. Então, fica dificil, eu acho que o grande problema é a Central de Vagas, eu acho que complicou, ficou de resolver e eu acho que complicou tudo. Antes, você ia para a Unesp e já resolvia o problema, hoje não, hoje você fica com o paciente aqui e não sabe o que fazer com o paciente, porque todo mundo fica desesperado, a familia então, chega até a chutar a porta.

\section{E - A Central de Regulação tem problemas: demora para decidir, não tem real controle sobre sua demanda às vezes encaminha pacientes sem considerar a falta de recursos do hospital (G4, G6, G7, G13, G14, G17).}

Eu acho que o grande problema é a Central de Vagas demorar muito para resolver o problema e quando a gente pede, é uma emergência a gente não pode ter uma demora tão grande.Tem dias que a gente espera 4, 5 horas por uma vaga. Então a gente fica desesperado, o paciente fica gritando, os parentes ficam pressionando a gente, o médico, fica na verdade todo mundo sem poder fazer nada e aquela cobrança em cima e atende até mal os pacientes. Porque bate na porta: - Doutor ele está gemendo, doutor ele está tal coisa.

Em uma ou duas oportunidades nós tentamos falar com a Central de Vagas para encaminhar paciente e a resposta que nós tivemos é que, como nosso municipio 
depende de outro nós temos que mandar para lá e se o outro acha que precisa é ele quem tem que mandar, nós não.

Agora parece que melhorou, mas antes a reclamação era a demora para dar a resposta, tanto que na outra gestão, do meu antecessor, aconteceu o seguinte: por falta de orientação, o médico daqui segurou o paciente, o paciente estava, depois que ficamos sabendo, com um aneurisma cerebral e ele ficou acho que umas duas horas aqui esperando a Central de Vagas e ela não dava o retorno e ficou complicado. Depois ele foi levado para Avaré e de lá foi para a Unesp. E isso parece que gerou uma polêmica na cidade.

Quando se pegam dados da Central de Regulação, aquilo que foi colocado em algum hospital da região não se transformou em internação, então a Central deu encaminhamento, mas aquele paciente não foi internado. Então será que a demanda que foi dada para a Central de Regulação era a verdadeira? Por que não se consegue localizar a internação desse paciente? O relatório da Central diz para onde mandou, tenta-se achar a internação, não se acha. Existe um Conselho gestor da Central, ele tem discutido essas coisas, porque hoje o estado colocou de incentivo para a nossa regional em torno de 28 mil reais/ mês em cima da internação ocorrida pela Central de Regulação. A gente sabe que a tabela do SUS é complicada em relação a média e alta complexidade, e principalmente na urgência-emergência, então o estado alocou recursos para minimizar esse custo financeiro, e hoje não se consegue gastar os $28 \mathrm{mil} / \mathrm{mês}$, porque não se acha onde está a internação daquele paciente, foi atendido pela Central e não é localizada no hospital que a Central registrou que o colocou. Então tem falhas aí. Ele pode ter sido atendido no Pronto Socorro, então aquilo que a Central passou pode não ter sido realmente uma urgência-emergência. Ou foi uma urgência-emergência que foi resolvida no Pronto Socorro, não necessitou de internação.

Outro problema que a gente teve com a Central de Vagas foi de um paciente que foi referenciado para nós. A Central referenciou um paciente que tinha sofrido politrauma que estava estabilizado e poderia dar continuidade ao tratamento, eu achei que aquilo que não era bem isso, o paciente estava em sepsis com uma febre em torno de 40 graus, medicação que a gente não tinha aqui, o antibiótico para 
poder estar agindo nós não tinhamos. E o paciente veio a óbito 7 dias depois aqui, correndo risco até de trazer uma infecção hospitalar que estava lá e veio para cá.

\section{F - A Central de Regulação é um avanço e pode avançar mais (G2, G4, G5, G10, G11, G15, G16).}

Eu acho que é um grande avanço a Central para o estado. Por quê?? Porque ela tirou do profissional que está atendendo aquela obrigação de localizar aonde vai colocar esse paciente, porque ali ele não tem condições de continuar. E o médico a gente sabe que é um médico só para o Pronto Socorro e para internação na grande maioria dos nossos hospitais. Já um hospital um pouquinho maior tem uma retaguarda estabelecida, mas nos nossos hospitais pequenos, que são a grande maioria, tem um médico no plantão que dá conta dos pacientes que estão internados também, não tem um médico para cada setor. Então, se é tirada essa responsabilidade do médico verificar aonde é que vai por esse paciente, ele já ligou para a Central e passou o caso, é a Central que está correndo por ele nesse sentido. Então eu acho isso um grande avanço.

As coisas têm melhorado. Existe já um embrião de rede de referência e contrareferência na região. Eu penso que, no caso especifico de Avaré, tem melhorado muito. Neste último ano, Avaré tem aceitado muito mais o seu papel de referência na sub-região de Avaré. Ela tem assumido para si, eu digo assim, na assistência materno-infantil, o que consegue resolver é lá. Resolve e aceita. Solicita de Botucatu apenas suporte para aqueles casos que exigem uma UTI neonatal, por exemplo, ou um parto de alto risco, que encaminha. O resto fica em Avaré. Ortopedia melhorou muito, eles também têm assumido o papel de referência importante na região, todos os casos, praticamente, vão para Avaré. Outra coisa que melhorou muito é a volta do paciente para o hospital de origem. Antes era assim, você encaminhava o paciente e o paciente saía do hospital, para o qual ele havia sido encaminhado com alta, curado, porque o de origem não recebia nunca mais. Isso tem melhorado. Eu atribuo essa melhoria às reuniões que a DIR tem promovido, onde não se cansam de colocar qual que é o papel de cada um e a questão da parceria.

$\dot{E}$, eu acho que melhorou bastante. Eu acho que hoje o retorno tem sido mais rápido. No começo foi complicado, mas acho que houve uma melhora, sim. As vezes a gente 
percebe ainda que alguns médicos têm uma certa rejeição em estar ligando para a Central de Vagas, porque alguma vez já foram mal atendidos.

Está sendo dado um curso de capacitação em urgência-emergência para todos os médicos e enfermeiros da região, para que fique mais ou menos uniforme o nosso encaminhamento, a nossa conduta, o que a gente vai fazer antes de colocar o paciente na estrada, então eu acho isso, também, um grande avanço. O curso é gratuito, bancado pelo estado, dado pela Unesp, que recebe os pacientes, então, o curso está dentro da realidade. Alguns profissionais do Pronto Socorro daqui fizeram o curso com a equipe e nós pudemos conhecer a realidade da Unesp, do Pronto Socorro e o Pronto Socorro conheceu a nossa realidade. Então hoje, tem um relacionamento muito mais interessante.

Também, existe uma proposta discutida, que é de uma consultoria em saúde e trabalha com a faculdade e trabalhou também com a Secretaria Municipal. É a CONSAÚDE, que é a entidade que está fazendo um estudo sobre a gestão plena municipal. A hora que a gente assumir a gestão plena municipal, seria interessante ter uma Central de Vagas municipal, como anteparo, antes da Central de Vagas regional. A Central de Vagas que tem na Unesp é regional. Seria interessante que passasse por uma triagem pela Central de Vagas municipal.

\section{G - A CRV precisa ser mais orientadora (G3).}

A Central de Regulação tem uma média aí de 400, 500 solicitações/mês. Quando ela foi criada, ela tinha como intuito fazer a regulação de urgência-emergência e usar o que ela tem de melhor, que é o grande observatório para impingir ou até administrar a distribuição de recursos. Isso ela não fez. Não consegue fazer, porque os recursos, têm outros crivos que não somente esse da Central. Outra coisa que ela deveria fazer e não faz, seria checar se aquele doente que lhe foi passada tal informação, foi realmente transferido com aquilo que se pretendia que transferisse e se ele chegou no destino e se o diagnóstico está correto...

O dinheiro para a Central está vindo porque se confia que atenda, a gente gosta de receber recurso, mas precisa da contrapartida. O pessoal precisa entender que tomografia de última geração, ultra-som, só veio porque existe um pacto de atendimento, então tem que atender. A Central se fosse mais orientadora, talvez 
fosse melhor. Isso é um trabalho que se tem procurado fazer. Olha, por que o paciente precisa vir? - Ah, porque ele está desidratado. - Desidratado? Ele está convulsionando? Quer dizer, ela precisa orientar mais. Outra coisa é, precisa ser uma resistência aos encaminhamentos não justificáveis. Tem-se procurado orientar. - "Olha eu queria encaminhar porque o cirurgião não veio". - Tá, então pede para o secretário da saúde ligar para a Central. É preciso que o secretário da saúde diga para a Central de Regulação, que neste dia o cirurgião não está lá e ele não tomou providência. Se ele fizer isso, se aceita o caso. Então tem que ser um pouco mais firme, nó sentido de ser uma barreira mesmo, não ao doente, mas à forma como esse doente está sendo tratado. E ela precisa ser mais orientadora e, na minha opinião, ela precisa cobrar mais dos municipios.

\section{H - A CRV trabalha com conceito de recusa zero para a alta complexidade (G3, G4, G9, G11).}

A CRV trabalha com conceito de recusa zero para alta complexidade, que é um conceito que a gente faz questão que a Central comece a colocar dentro do Hospital das Clinicas, que foi uma resistência muito grande e ainda é. Então, nós temos dois conceitos: um é o conceito de vaga. Vaga é um conceito temporal. A vaga que eu não tenho hoje eu tenho amanhã. Então por falta de vaga nenhum paciente deve deixar de ser assistido, porque vaga é um conceito de momento: hoje eu tenho, amanhã não tenho e ela não impede que o doente seja atendido, se eu tenho recurso. Então, se eu tenho recurso mas não a vaga, eu preciso atender aquele doente. Então, veja bem, tem profissionais no quarto de plantão, centro cirúrgico parado, hemocentro funcionando, pronto socorro aberto, tem um politraumatizado em Itatinga, ele não iria para a UNESP porque não tem vaga para interná-lo? Não tem sentido. Não tem sentido ele não ir, não é? Tem tudo na UNESP. Não tem o leito para ele, mas isso é uma questão que amanhã se resolve. Se ele estiver vivo amanhã se resolve. Então é um conceito assim, de recusa zero para alta complexidade, é uma coisa que se tem procurado seguir, porque seria até ético.

Os gestores falam do relacionamento tenso entre os profissionais dos municípios e a Central de Regulação, apontando situações em que são omitidos 
detalhes importantes sobre as condições reais do paciente, no sentido de se conseguir o encaminhamento do doente. Algumas dessas situações e condutas chegam a por em risco a vida do doente, além de revelarem a não observância de aspectos éticos do relacionamento profissional e da assistência ao doente.

Parece haver uma certa desconfiança da parte da Central de Regulação Médica sobre as informações prestadas pelo médico solicitante do encaminhamento e ao mesmo tempo, da parte dos solicitantes quanto à conduta que será tomada pela Central de Regulação Médica. Isto acaba gerando encaminhamentos diretos dos pacientes ao Pronto Socorro da UNESP, sem solicitação prévia à Central de Regulação Médica, como no exemplo relatado, de encaminhamento direto ao PS da UNESP por desconfiar de que a Central de Regulação Médica pudesse não entender o caso do doente como urgência e viesse a agendar uma consulta à Triagem de Especialidades, retardando o atendimento.

Por outro lado, destaca-se a observação de entrevistados de que o Pronto Socorro da UNESP tem sido procurado para se conseguir um agendamento de consulta mais rápido na Triagem de Especialidades.

O município de Botucatu é apontado como aquele que menos respeita as regras de encaminhamentos, enviando doentes para o PA ou SE da UNESP sem contato prévio, sob justificativa de que é mais fácil colocar o doente na ambulância e levá-lo à UNESP do que ser atendido pela Central de Regulação Médica.

Gestores entrevistados entendem que a Central de Regulação Médica deveria orientar mais os solicitantes, desenvolver procedimentos mais ágeis para atendimento dos casos graves, não atender os casos que não se justificam, cobrar responsabilidades dos municípios e se constituir em barreira "não ao doente, mas à forma como está sendo encaminhado". A Central de Regulação Médica deve ser o elemento orientador da assistência pré-hospitalar e o médico, que nela atua, deve ter capacidade de julgamento para discernir a urgência real da urgência aparente (BRASIL 1999).

São apontados, ainda, aspectos de comportamentos habituais ligados aos usuários da região, de exigências para encaminhamentos ao PA ou SE da UNESP, embora os serviços de saúde e hospitais dos seus municípios ou de municípios mais próximos estivessem preparados para o atendimento necessário. 
Apesar de ainda confuso e um tanto desorganizado, o sistema de atendimento instituído com a implantação da Central de Regulação Médica vem dando reconhecido suporte aos municípios. As melhorias no sistema estão ocorrendo graças ao empenho e participação de profissionais da região nas reuniões realizadas para discussão e enfrentamento dos problemas, além dos cursos que estão sendo desenvolvidos visando à capacitação de médicos e enfermeiros da região para os atendimentos de urgência/emergência. 


\subsection{Triagem de Especialidades}

Em levantamento feito no mês de março de 2002, sobre o volume de atendimentos realizados na Triagem de Especialidades Médicas aos munícipes da região da DIR XI, excluindo-se o município de Itaberá que ainda não pertencia à região, obteve-se os seguintes resultados apresentados na tabela 3.

Tabela 3 - Distribuição de freqüências absolutas e relativas dos atendimentos feitos na Triagem de Especialidades do HC - FMB, segundo municípios da DIR IX, Botucatu, março de 2002

\begin{tabular}{|c|c|c|c|}
\hline Municípios & $\begin{array}{c}\text { Frequiência } \\
\text { absoluta }\end{array}$ & $\begin{array}{c}\text { Freqüência } \\
\text { relativa }\end{array}$ & $\begin{array}{c}\text { Atendimentos/ } \\
\text { População do } \\
\text { município* }\end{array}$ \\
\hline Águas de Santa Bárbara & 13 & 1,27 & 0,23 \\
\hline Anhembi & 38 & 3,73 & 8,37 \\
\hline Arandu & 7 & 0,69 & 1,15 \\
\hline Areiópolis & 19 & 1,86 & 1,84 \\
\hline Avaré & 13 & 1,27 & 0,17 \\
\hline Bofete & 25 & 2,45 & 3,40 \\
\hline Botucatu & 389 & 38,14 & 3,60 \\
\hline Cerqueira César & 38 & 3,73 & 2,51 \\
\hline Conchas & 28 & 2,75 & 1,87 \\
\hline Coronel Macedo & 23 & 2,25 & 4,12 \\
\hline Fartura & 12 & 1,18 & 0,80 \\
\hline Iaras & 1 & 0,10 & 0,30 \\
\hline Itaí & 24 & 2,35 & 1,14 \\
\hline Itaporanga & 48 & 4,70 & 3,35 \\
\hline Itatinga & 32 & 3,14 & 0,06 \\
\hline Laranjal Paulista & 46 & 4,50 & 2,23 \\
\hline Manduri & 12 & 1,17 & 2,10 \\
\hline Paranapanema & 14 & 1,37 & 1,45 \\
\hline Pardinho & 21 & 2,06 & 0,90 \\
\hline Pereiras & 27 & 2,65 & 4,43 \\
\hline Piraju & 25 & 2,45 & 4,41 \\
\hline Porangaba & 11 & 1,07 & 0,90 \\
\hline Pratânia & 11 & 1,07 & 1,65 \\
\hline São Manuel & 79 & 7,74 & 2,78 \\
\hline Sarutaia & 1 & 0,10 & 2,17 \\
\hline Taguai & 4 & 0,39 & 0,13 \\
\hline Taquarituba & 33 & 3,24 & 0,18 \\
\hline Tejupá & 9 & 0,88 & 1,50 \\
\hline Torre de Pedra & 1 & 0,10 & 1,69 \\
\hline Total & 1020 & 100,0 & 0,45 \\
\hline
\end{tabular}

*Número de atendimentos/população do município (2000)/1000 habitantes 
Observa-se que a grande demanda na Triagem de Especialidades foi de pacientes de Botucatu (38,14\%) seguida pelos pacientes de São Manuel $(7,74 \%)$, que pode ser explicada pelo maior número de quotas para consultas oferecidas a esses dois municípios, os quais são os mais populosos da sub-região de Botucatu. Porém, observa-se ainda, que municípios pequenos têm a Triagem como importante referência médica. Os municípios de Anhembi, Pardinho, Coronel Macedo e Pereiras, em proporção ao número de habitantes, tiveram maior representação na Triagem. Não houve registro de nenhum paciente do municipio de Barão de Antonina, que é o que fica mais distante de Botucatu. Os gestores falam sobre as quotas dos municípios na Triagem de Especialidades e o relacionamento Triagem/municípios respondendo a questão seguinte:

O que você acha da sua quota de vagas na Triagem de Especialidades da UNESP e como está se dando o relacionamento do seu município com a Triagem?

\section{Quadro Sintese das Idéias Centrais}

\begin{tabular}{|l|l|}
\hline A & $\begin{array}{l}\text { O estabelecimento de quotas da Triagem aos municípios representou um } \\
\text { avanço. }\end{array}$ \\
\hline B & As quotas dos municípios são insuficientes. \\
\hline C & Como foram estabelecidas as quotas aos municípios \\
\hline D & A Triagem tem erros conceituais. \\
\hline E & A UNESP precisa devolver o doente. \\
\hline F & A Triagem desobrigou os municípios a criarem ambulatórios. \\
\hline G & As quotas insuficientes obrigam os municípios a buscarem outras soluções. \\
\hline H & Os pacientes atendidos na UNESP trazem gastos maiores aos municípios. \\
\hline
\end{tabular}

A - $O$ estabelecimento de quotas da Triagem aos municípios representou um avanço (G1, G5).

Acho que isso é importante, primeiro porque acaba jogando para o município a própria gestão da consulta e acho que isso ai acaba obrigando o município a ter uma clareza do que vai encaminhar, por quê vai encaminhar, diferente do que era antigamente: se o paciente tinha um problema de pele, então punha numa 
ambulância e mandava para a UNESP, só que aquele problema de pele podia ter sido resolvido ao nivel de unidade básica de saúde e acabava não sendo, então ia para a Unesp para tratar. Então, hoje, o que acontece? Os casos são triados e acaba indo para a Unesp, para algumas especialidades, realmente alguns casos que têm que acabar indo para lá. Acho que isso é um avanço, achei que é importante ao nivel de municipio...

Mas a Unesp está cobrando da gente que está havendo muila falta nos agendamentos, então nós estamos vendo o que está acontecendo. Por que as pessoas que têm dificuldades no agendamento e quando elas conseguem o agendamento elas não vão? Eu conversei isso com os enfermeiros chefes das unidades, o que é que estava acontecendo, por que as pessoas estavam faltando? Eles tiveram duas explicações: uma, as pessoas são agendadas para muito longe, muito distante do momento, a pessoa está precisando de um atendimento e é agendada para 6 meses, quando chega a vez dela ser consultada ela já se virou, ou ela pagou consulta particular ou na Unimed, ou ela conseguiu furar a fila via Pronto Socorro e acabou entrando lá dentro, então, não vai. Ela já resolveu aquele problema dela.

\section{B - As quotas dos municípios são insuficientes (G2, G5, G6, G7, G8, G9, G10, G12, G13, G14, G15, G16, G17).}

As quotas são muito insuficientes. Aí é que eu não sei, fazendo um papel de neutro, de ficar de fora e pensar o problema da Unesp. Eu não sei se todo mundo que está sendo encaminhado para a especialidade precisaria. Se a gente tivesse uma maior resolutividade no nível primário e nós vamos fazer um teste disso quando a gente tiver o médico de familia, se resolver mais, talvez eu precise de menos especialistas para resolver e pode ser que as quotas sejam mais razoáveis. $O$ ambulatório de especialidades (NGA) não consegue absorver toda a demanda, primeiro porque cle está com poucos profissionais, segundo porque a consulta no ambulatório de especialidades até se consegue, mas o procedimento decorrente da consulta, por exemplo, o gastro-cirurgião faz a consulta e diz: - Olha, você precisa operar o estômago, mas eu não faço cirurgia pelo SUS, eu sou só consultante do SUS. -O que adianta uma consulta com um gastro-cirurgião para ele dizer que precisa de 
uma cirurgia, mas que ele não faz? $O$ ambulatório de especialidades é um Frankstein, com pedaços de vários cadáveres, não é? Com um pedacinho do CSI antigo, um pedaço grande, até razoável, do ambulatório de especialidades do PAM do INAMPS e uma boa parte que foi colocada depois pelo estado.

Tem algumas especialidades da Triagem que não têm vaga mais para este ano, só para o ano que vem.

Na área de gastrocirurgia que são pessoas que têm problemas na vesícula, às vezes, é complicado. Ficam 2 anos, 2 anos e meio na fila esperando vaga. Hérnia em criança, hérnia em adulto, figado é uma fila de 5 mil na frente na Unesp. $O$ que a gente vai fazer? Tem que esperar ou tem que batalhar para ver se aumenta...Essa quota também está insuficiente principalmente para ortopedia, otorrino, que a gente não tem e não tem conseguido agendar otorrino, está suspenso, e ultimamente suspendeu endócrino.

Muitas vezes mandamos o paciente para outras regiões, quando o paciente tem parente e a gente acha também que dá para ser resolvido a gente manda, devido a essa dificuldade

O que eu sei é que a quota que a Unesp oferece aos municipios é muito pequena, ela é insuficiente. É a única coisa que eu posso te dizer.

\section{C - Como foram estabelecidas as quotas aos municipios ( $\mathrm{G} 3$ ).}

Essa quota está imutável há 4 anos. Ela foi idealizada em 98. Ela sofreu até uns reveses no sentido de diminuição de quota. Mas, ela foi estabelecida mediante um critério, que foi a média histórica dos municipios que demandavam ao HC. A triagem tinha uma fila danada, os pacientes chegavam à noite e, às vezes, não conseguiam consulta. Mas o número de consultas que eram oferecidas por especialidade por mês, era maior que o número de consultas efetivamente realizadas. Por quê? Porque tinha assim, naquele dia era terça-feira tinha 4 vagas de cárdio, chegavam 5 pacientes, um não era atendido, ia embora e não tinha garantia que ia ser atendido no dia seguinte. No outro dia as 4 vagas de cardio permaneciam, mas apareciam 2 pacientes. Eles eram atendidos, os dois, e ainda sobravam duas vagas. Então a gente fez um estudo, que o número de vagas, por 
exemplo, de cardio, que era oferecido era maior que o de atendimento, apesar de que tinha paciente que não era atendido. Não houve, assim, um crescimento vegetativo tão grande na população nesses últimos 4 anos, porque o que influencia na triagem é o crescimento vegetativo dos adultos que isso é um movimento migratório... Então acho que a quota é insuficiente porque é mal utilizada. Mas se você admitir que ela foi baseada numa demanda real e estabelecida por um fluxo espontâneo e que o crescimento vegetativo não interferiu, e que o crescimento imigratório foi quase nulo, então acho que ela é a mesma de 4 anos, mas eficiente.

\section{D - A Triagem tem erros conceituais. (G3, G4, G10, G11, G12, G15).}

A triagem, eu acho que ela é assim. Eu não sei se isso é verdade, mas eu imagino a triagem como sendo a concretização do ego do docente da escola. Ele não admite nenhum doente no seu ambulatório que não passou por uma triagem, porque não admite que um médico encaminhe para o seu ambulatório um doente que não the interessa e esse interesse é um interesse que ele avalia se é bom ou ruim. "Vocé imagina que algum médico do posto de saúde ali do bairro vai encaminhar para o meu ambulatório um doente? Não, eu vou fazer uma triagem antes" Eu acho até anti-ético a triagem. Em todo caso, ela existe. Agora, é o que eu falo da demora, se o paciente já saiu daqui com uma triagem por que ele tem que passar em outra triagem para ai passar num especialista lá? Seria muito mais rápido se o meu médico daqui, encaminhando para lá, ele já fosse direto para a especialidade lá, não passando por outra triagem, é isso que é a demora de lá.

Na minha opinião, não precisava ter o P.A precisava ter o Pronto Socorro, não precisava ter a triagem, precisava ter ambulatório. Nós temos três erros conceituais na triagem. Um é esse da própria triagem. Acho que a triagem não deveria existir, devia existir o seguinte: um protocolo de encaminhamentos dos pacientes das unidades, nem das unidades, porque esse é outro erro de conceito. Você está queimando uma etapa, você está encaminhando um paciente da unidade básica para um hospital terciário. Mas em todo caso, então, um primeiro conceito, na minha opinião, errado é da própria triagem, ela existe. Agora, é o que eu falo da demora, se o paciente já saiu daqui com uma triagem por que ele tem que passar em outra 
triagem para ai passar num especialista lá? Seria muito mais rápido se o meu médico daqui, encaminhando para lá, ele já fosse direto para a especialidade lá, não passando por outra triagem, é isso que é a demora de lá.

Vai com o médico e pactua um protocolo: quando você tiver uma pneumonia dessa maneira você manda para mim, porque isso aqui exige tais e tais coisas, agora o resto das pneumonias a gente pode combinar como é que se trata. Se você tiver insucesso você me manda. Para onde? Para o ambulatório.

\section{E - A UNESP precisa devolver o doente (G3, G10, G11, G12, G15).}

O ambulatório precisa começar a dar alta. Os ambulatórios da UNESP devem ter o indice de alta mais baixo do mundo. Não dão alta. É preciso dar alta, devolver o doente.

Às vezes a gente até coloca para os médicos da Unesp, quando participam da reunião da CIR, que a gente acha que a falha da Unesp é que nós não temos retorno desses pacientes. Muitas vezes eles não têm nada ou poderiam estar sendo seguidos aqui, mas são pouquíssimos os profissionais que dão esse retorno, então a gente perde. Ele vai uma vez e lá mesmo acaba conseguindo ir para outras especialidades, então acaba ficando lá. Nunca mais volta. Ele volta para pegar a fichinha e continuar indo.

São pacientes que ficam a vida inteira, às vezes, a gente quer trazer o paciente de volta. - Não, porque o médico falou que tem que fazer. Eu tenho hemodiálise no meu município, 3 pacientes não têm jeito, eu tentei de tudo para que eles venham para cá mas a Unesp não me libera e faz a cabeça dos pacientes que tem que fazer a hemodiálise lá. Ai fica dificil. Tenho eu que mandar meu paciente ficar fazendo hemodiálise lá, quando tenho aqui. Então eu acho que tinha que entrar num acordo com isso.

\section{F - A Triagem desobrigou os municípios a criarem ambulatórios (G3)}

Então outro conceito, que está errado da triagem e que aconteceu foi que parece que desobrigou um pouco os municipios de criarem ambulatórios nos seus municipios. Eu tenho quota de cardio, por que eu vou contratar um cardio? E os municipios 
disseram, eu estou com uma fila de espera de um ano de cardio. Fila de espera de um ano de cardio? Quantos pacientes são? Ah, eu tenho 4 pacientes por mês, 50 doentes esperando. Contrata um cardiologista, ele faz 12 consultas por dia se trabalhar 20 horas, então se 5 cidades contratarem um cardiologista ele resolve o problema de 5 cidades. $E$ ai esse cardiologista, ele sim encaminha para a triagem de especialidade, por quê? Porque ele precisa de um Eco, de uma Cinecoronário, bom, por que esse é hospital terciário.

G - As quotas insuficientes obrigam os municípios a buscarem outras soluções (G10, G17).

Para mim, algumas especialidades são muito dificeis, mas eu acho também que eu obrigo o municipio a tomar uma atitude, eu tomei com o otorrino, ele vai vir o ano que vem.

Na cidade não tem oftalmologista, vem um do municipio de referência. Inclusive antes de eu entrar ele usava este serviço, mas por orientação da DIR eu não posso deixá-lo aqui. Ele faz um preço especial no atendimento e isso beneficia a população. Só que, como ele cobra, eu não posso deixá-lo dentro de um órgão público. Então ele fez um acordo com o sindicato rural e ele tem uma sala no sindicato rural onde ele faz os atendimentos à população e cobra $50 \%$ do valor da consulta, e ele está atendendo no sindicato. Esse folhetinho que você viu que ele coloca no quadro, ele pede autorização, as pessoas então podem escolher...

H - Os pacientes atendidos na UNESP trazem gastos maiores aos municípios (G10).

A Unesp tem um atendimento terciário, até o próprio profissional, ele sabe assim, que pneumonia dá para tratar até com Ampicilina, mas não, ele já vai lá nos últimos dos últimos, entra com Vancomicina, com o diabo a quatro, com Cipro, então assim, fica muito dificil esse retorno do paciente para nós assumirmos isso dai. Eu tenho paciente que ele precisava de um CPAP, que é um respirador para ele conseguir dormir. Ele veio para a gente. Não, não tem condições, a gente não tem o 
equipamento e tal. Se você visse a carta que me mandaram, que se eu não respondesse juridicamente eu estava perdida. Eu loquei esse caso. Eles souberam que eu loquei, mandaram outro paciente para mim. Eles pedem exames absurdos, por exemplo, ressonância a minha referência é a Unesp, só que a Unesp não me dá ressonância, não adianta, ela não me dá. Eu tenho que pagar 800, 1000 reais numa ressonância para eles verem e eles têm lá o aparelho, mas o paciente é meu o problema é meu. Então, fica dificil isso. Eu tenho um paciente que tem que tomar Tegretol e no municipio tem o genérico, a Carbamazepina. No ambulatório o médico prescreveu Tegretol. Pô, espera ai gente, o Tegretol custa, sei lá, 400 reais, Carbamazepina custa 100. Então o paciente fala assim: - Você leu, foi a Unesp, foi médico da Unesp, porque senão eu vou ter que acionar o Ministério da Saúde. E daí está no artigo da Constituição que a saúde é um direito de todos e dever do estado. Ai fica dificil, né? Ninguém sobrevive.

Os gestores entendem que as quotas dos seus municípios na Triagem Médica de Especialidades são insuficientes. Não fica muito claro que o modo como essas quotas foram estabelecidas tenha sido realmente baseado em demanda real, se for levado em conta que muitos doentes, no passado, não tiveram acesso ao atendimento da Triagem.

Sabe-se que a distribuição das quotas entre os municipios procurou ser eqüitativa, no entanto, problemas relacionados, principalmente, à funcionalidade dos mecanismos adotados para agendamentos e às deficiências dos outros serviços existentes na região, para o atendimento por especialistas, em nível ambulatorial, estão dificultando o acesso dos usuários desta região nesse nível da assistência médica.

A própria Triagem de Especialidades tem se constituído em barreira à essa acessibilidade ao nível secundário ambulatorial, fato que foi apontado pelos gestores como um dos erros conceituais dessa unidade de atendimento.

As contradições presentes nessa realidade, decorrentes, principalmente, da escassez de serviços de atendimento em nivel secundário, geram ambigüidades, como a observada nos discursos dos gestores que se queixam das insuficiências de vagas para a Triagem, mas, ao mesmo tempo, têm receios quanto aos atendimentos feitos pelas especialidades médicas da UNESP, relativos a pedidos de exames, 
tratamentos e medicamentos muito caros, com os quais os municípios, muitas vezes, terão que arcar. A conduta médica acadêmica nem sempre está atenta às condições sociais e econômicas das pessoas e do meio em que elas vivem e, muitas vezes, mantém-se à margem até mesmo de determinações legais. Isto foi mencionado por gestores entrevistados, ao comentarem as prescrições de medicamentos genéricos. Houve relatos informais sobre médicos que alertam seus pacientes para não utilizarem certos medicamentos genéricos, alegando que estes são ineficazes, causando inseguranças e pressões dos usuários para obtenção dos medicamentos de acordo 'com a prescrição e recomendação do médico que os atendeu.

Para a realização de exames mais caros, como tomografia computadorizada e ressonância magnética nuclear, há sempre dificuldades de vagas no hospital universitário. Porém, não se ignora que também há situações no hospital universitário, que é uma instituição onde se faz pesquisas, que esses tipos de exames são feitos por interesse cientifico, em número e tipo desnecessários para o usuário. Os recursos para essa atividade de pesquisa, que deveriam ser buscados nas agências financiadoras e por vezes não são, acabam comprometendo o atendimento dos usuários. Esta é uma questão ética que deve ser administrada pelos comitês de ética em pesquisa das instituições públicas.

Identificou-se, ainda, o chamado "seqüestro de pacientes" pelo hospital universitário, porque este não "devolve nunca mais" o paciente para o seu municipio. O hospital universitário sente-se sobrecarregado e com dificuldades para atender a demanda, mas não "abre mão" do doente para que ele seja acompanhado em seu municipio.

Os municípios, ao enfrentarem os dilemas de falta de especialistas, procuram maneiras para solucioná-los. Algumas condutas adotadas são coerentes e responsáveis e outras nem sempre lícitas ou éticas, como se pode inferir de discursos de gestores apresentados. 


\subsection{Razões e motivos para a busca do atendimento no Serviço de Urgência/Emergência do HC - FMB.}

Foram entrevistados no Serviço de Urgência/Emergência do HC - FMB, no mês de março de 2002, 410 pacientes ou acompanhantes, sendo 150 (36,6\%) pacientes no Pronto Atendimento (PA) e $260(63,4 \%)$ no Setor de Emergência (SE). Quando entrevistados acompanhantes, estes foram solicitados a prestarem informações, em todos os itens, sobre o doente e não sobre si mesmos, apenas quando se tratou de acompanhantes de crianças, as informações sobre escolaridade e ocupação foram relativas ao chefe da família - pai, mãe ou responsável.

No PA, 88 (58,67\%) dos entrevistados eram do sexo feminino e no SE 141 $(54,23 \%)$ eram do sexo masculino, indicando diferenças para a procura dos dois tipos de serviços, ou seja, mais mulheres procuraram o PA e mais homens demandaram o SE.

A escolaridade dos entrevistados é apresentada na tabela 4.

Tabela 4 - Distribuição de freqüências absolutas e relativas na amostra de pacientes entrevistados no Serviço de Urgência/Emergência do HC - FMB, segundo a escolaridade, Botucatu, março de 2002

\begin{tabular}{|c|c|c|}
\hline Escolaridade & Freqüência absoluta & Freqüência relativa \% \\
\hline Sem escolaridade & 36 & 8,7 \\
\hline $1^{\circ}$ grau incompleto & 127 & 31,0 \\
\hline $1^{\circ}$ grau completo & 117 & 28,5 \\
\hline $2^{\circ}$ grau incompleto & 25 & 6,1 \\
\hline $2^{\circ}$ grau completo & 60 & 14,6 \\
\hline Curso técnico completo & 05 & 1,2 \\
\hline Curso superior incompleto & 12 & 2,9 \\
\hline Curso superior completo & 13 & 3,2 \\
\hline Sem informação & 15 & 3,6 \\
\hline Total & 410 & 100,0 \\
\hline
\end{tabular}


Aproximadamente $70 \%$ dos entrevistados têm escolaridade de $1^{\circ}$ grau completo ou menos, ou seja, têm menos de 8 anos de estudo.

Dentre as ocupações dos entrevistados, a maior freqüência $(15,85 \%)$ foi de aposentados, seguida por $11,22 \%$ de ocupações do lar, 7,32\% de trabalhadores do serviço doméstico, $7,32 \%$ de desempregados, 5,12\% de trabalhadores da agropecuária, 4,39\% de pedreiros, $3,9 \%$ vendedores em lojas, $2,68 \%$ estudantes e $42,2 \%$ as demais profissões.

A escolaridade e as ocupações dos entrevistados indicam o baixo poder aquisitivo dos usuários que demandam aos Serviços de Urgência/Emergência da UNESP e a sua dependência do SUS.

As faixas etárias dos entrevistados são apresentadas na tabela 5.

Tabela 5 - Distribuição de freqüências absolutas e relativas na amostra de pacientes entrevistados no Serviço de Urgência/Emergência do HC - FMB, segundo a faixa etária e o local de atendimento, Botucatu, março de 2002

\begin{tabular}{|c|c|c|c|c|c|c|}
\hline \multirow{2}{*}{ Faixa etária } & \multicolumn{2}{|c|}{$\begin{array}{c}\text { Local } \\
\mathbf{P A}\end{array}$} & \multicolumn{2}{|c|}{ SE } & \multicolumn{2}{|c|}{ Total } \\
\hline & $\mathbf{N}$ & $\%$ & $\mathbf{N}$ & $\%$ & $\mathbf{N}$ & $\%$ \\
\hline$<1$ ano & - & - & $19^{*}$ & 100,0 & 19 & 4,63 \\
\hline $1 \vdash 5$ & - & - & $51^{*}$ & 100,0 & 51 & 12,44 \\
\hline $5 \vdash 15$ & 8 & 15,38 & $44^{*}$ & 84,62 & 52 & 12,68 \\
\hline $15 \vdash 30$ & 46 & 45,54 & 55 & 54,46 & 101 & 24,63 \\
\hline $30 \vdash 50$ & 54 & 52,43 & 49 & 47,57 & 103 & 25,12 \\
\hline$\geq 50$ & 42 & 50,0 & 42 & 50,0 & 84 & 20,49 \\
\hline Total & 150 & 36,6 & 260 & 63,4 & 410 & 100,0 \\
\hline
\end{tabular}

As diferenças encontradas entre menores de 15 anos no SE são explicadas pelo fato destes serem atendidos exclusivamente no SE, pois o PA atende, em geral, apenas maiores de 15 anos. 
A procedência dos entrevistados no PA e SE é apresentada na tabela 6, na qual os municípios de procedência foram agrupados segundo classificação prevista pelo Plano Diretor de Regionalização.

Tabela 6 - Distribuição de freqüências absolutas e relativas na amostra de pacientes entrevistados no Serviço de Urgência/Emergência do HC - FMB, segundo município de procedência, classificado de acordo com o Plano Diretor de Regionalização, e o local de atendimento, Botucatu, março de 2002

\begin{tabular}{|c|c|c|c|c|c|c|}
\hline \multirow{3}{*}{ Procedência } & \multicolumn{4}{|c|}{ Local de atendimento } & \multirow{2}{*}{\multicolumn{2}{|c|}{ Total }} \\
\hline & \multicolumn{2}{|c|}{$\mathbf{P A}$} & \multicolumn{2}{|c|}{ SE } & & \\
\hline & $\mathbf{N}$ & $\%$ & $\mathbf{N}$ & $\%$ & $\overline{\mathbf{N}}$ & $\%$ \\
\hline Sede de módulo e pólo (DIR XI) & 86 & 31,27 & $189^{*}$ & 68,73 & 275 & 67,07 \\
\hline Adscritos à Sede de módulo e pólo (DIR XI) & 2 & 20,0 & 8 & 80,0 & 10 & 2,44 \\
\hline Sedes de módulo (DIR XI) & $27^{*}$ & 43,55 & 35 & 56,45 & 62 & 15,12 \\
\hline Adscritos às Sedes de módulo (DIR XI) & $13^{*}$ & 61,9 & 8 & 38,10 & 21 & 5,12 \\
\hline Outras regiões & $20 *$ & 55,56 & 16 & 44,44 & 36 & 8,78 \\
\hline Sem informação & 2 & 33,33 & 4 & 66,67 & 6 & 1,46 \\
\hline Total & 150 & 36,6 & 260 & 63,4 & 410 & 100,0 \\
\hline
\end{tabular}

Observa-se significativa demanda de procedentes do município sede de módulo e pólo (Botucatu) no SE, enquanto os procedentes de municípios adscritos aos sedes de módulo, procedentes de municípios sedes de módulo e de outras regiões demandaram mais o PA. Isto pode estar indicando que os pacientes procedentes de Botucatu apresentaram problemas mais graves para serem atendidos no SE ou compareceram fora do horário de atendimento do PA. Como 60,3\% destes pacientes, segundo informação médica, que será apresentada na tabela 16 , não apresentaram problemas que merecessem atendimento de urgência, mas que poderiam ser acompanhados em Unidades Básicas, este dado sugere que a demanda ao SE foi mais em função do horário de funcionamento, pois em outros horários esses pacientes seriam atendidos no PA. 
Verifica-se que apenas 36 pacientes $(8,8 \%)$ foram procedentes de outras regiões o que indica que o $\mathrm{HC}$ - FMB, de certo modo já vem apresentando um acentuado caráter regional. Isto tem sido observado também em relação à procedência dos indivíduos internados. Foi apurado no mês de março de 2002 que $82 \%$ das internações no HC - FMB foram de procedentes da região da DIR XI.

Destaca-se ainda que destes 36 pacientes entrevistados, procedentes de outras regiões, apenas 4 receberam atendimento classificado como urgência/emergência, indicando que a procura do Serviço de Urgência/Emergência, na maioria dos casos, não foi motivada por uma situação de emergência.

Os vínculos dos entrevistados com serviços de saúde onde residiam encontram-se apresentados na tabela 7.

Tabela 7 - Distribuição de freqüências absolutas e relativas na amostra de pacientes entrevistados no Serviço de Urgência/Emergência do HC - FMB, segundo a faixa etária e a existência de vínculos com serviços de saúde do município onde reside, Botucatu, março de 2002

\begin{tabular}{|c|c|c|c|c|c|c|}
\hline \multirow{3}{*}{$\begin{array}{l}\text { Faixa etária } \\
(\text { anos })\end{array}$} & \multicolumn{4}{|c|}{ Vínculos } & \multirow{2}{*}{\multicolumn{2}{|c|}{ Total }} \\
\hline & \multicolumn{2}{|c|}{ Sim } & \multicolumn{2}{|c|}{ Não } & & \\
\hline & $\mathbf{N}$ & $\%$ & $\mathbf{N}$ & $\%$ & $\mathbf{N}$ & $\%$ \\
\hline$<1$ ano & $17 *$ & 89,47 & 2 & 10,53 & 19 & 4,63 \\
\hline $1 \vdash 5$ & $47^{*}$ & 92,16 & 4 & 7,84 & 51 & 12,44 \\
\hline $5 \vdash 15$ & $48^{*}$ & 92,31 & 4 & 7,69 & 52 & 12,68 \\
\hline $15 \vdash 30$ & 69 & 68,32 & 32 & 31,68 & 101 & 24,63 \\
\hline $30 \vdash 50$ & 86 & 83,50 & 17 & 16,50 & 103 & 25,12 \\
\hline$\geq 50$ & 67 & 79,76 & 17 & 20,24 & 84 & 20,49 \\
\hline Total & 334 & 81,5 & 76 & 18,5 & 410 & 100,0 \\
\hline
\end{tabular}

Verifica-se que nas faixas de menores de 15 anos há maior percentual de vínculos com serviços de saúde do município onde residem, enquanto o menor percentual $(68,32 \%)$ ocorreu na faixa de 15 a 30 anos. Este dado sugere que os municípios da região estão dando atenção e acolhimento especiais às crianças e 
adolescentes. Já na idade adulta, talvez uma procura maior por especialistas, os quais não estão presentes na maioria das Unidades Básicas, esteja dificultando os vínculos dessa clientela com os serviços de saúde.

Quanto à distribuição por sexo, $88,41 \%$ das mulheres e $74,38 \%$ dos homens entrevistados referiram vínculos com serviços de saúde do município. O tipo de serviço de saúde mais citado (64,9\%) foi Unidade Básica de Saúde.

Em geral, as mulheres se utilizam mais dos serviços de saúde do que os homens e há estudos demonstrando que essa diferença está relacionada a aspectos reprodutivos (LAMBREW 2001) ou a avaliação mais negativa que as mulheres tendem a fazer sobre seu estado de saúde (VERBRUGGE e WINGARD 1987), ou valorizam mais os sintomas que apresentam.

Os dados apurados nesta pesquisa são condizentes com os encontrados na literatura, mas são poucos os estudos que analisaram os determinantes dessas desigualdades na utilização de serviços de saúde por homens e mulheres, o que também não foi objeto desta pesquisa. De acordo com TRAVASSOS et al. (2002), existe a hipótese de que as desigualdades no uso de serviços de saúde devem variar entre os gêneros sempre que houver uma relação de subordinação, recomendando que sejam formuladas políticas que levem em conta as diferenças no padrão de uso dos serviços por homens e mulheres.

Também pode estar ocorrendo entre os individuos do sexo masculino maior vinculação a trabalhos que oferecem assistência médica.

Nesta região do estudo, o horário de funcionamento das UBSs, em geral, coincide com o horário de trabalho de grande número de pessoas, principalmente trabalhadores da agropecuária, pedreiros e vendedores, dificultando a freqüência destes às UBSs.

Este aspecto também está relacionado à organização da assistência nos municípios e na região, à acessibilidade e equidade, ao acolhimento do usuário pelos serviços de saúde, à qualidade do atendimento e à participação dos munícipes na gestão do sistema.

Os pacientes entrevistados no Serviço de Urgência/Emergência da UNESP que informaram não freqüentar nenhum serviço de saúde do municipio onde residem, em número de 76 , os quais correspondem a $18,5 \%$ dos entrevistados, citaram vários motivos que são apresentados na tabela 8 . 
Tabela 8 - Distribuição de freqüências absolutas e relativas na amostra de pacientes entrevistados no Serviço de Urgência/Emergência do HC - FMB segundo os motivos apontados para não freqüentar serviços de saúde locais e município de procedência, classificado de acordo com o Plano Diretor de Regionalização, Botucatu, março de 2002

\begin{tabular}{|c|c|c|c|c|c|c|c|c|c|c|c|c|c|c|}
\hline \multirow{3}{*}{ Motivos } & \multicolumn{14}{|c|}{ Procedência } \\
\hline & \multicolumn{2}{|c|}{ SMP* } & \multicolumn{2}{|c|}{ AdsMP* } & \multicolumn{2}{|c|}{$\mathbf{S M}^{*}$} & \multicolumn{2}{|c|}{ AdsM* } & \multicolumn{2}{|c|}{ Outros* } & \multicolumn{2}{|c|}{$\mathrm{SI}^{*}$} & \multicolumn{2}{|c|}{ Total } \\
\hline & $\mathbf{N}$ & $\%$ & $\mathbf{N}$ & $\%$ & $\mathbf{N}$ & $\%$ & $\mathbf{N}$ & $\%$ & $\mathbf{N}$ & $\%$ & $\mathbf{N}$ & $\%$ & $\mathbf{N}$ & $\%$ \\
\hline Procura a UNESP quando doente & 7 & 2,5 & - & - & 1 & 1,6 & - & - & 1 & 2,8 & - & - & 9 & 2,2 \\
\hline Reside há pouco tempo no município & 10 & 3,6 & 1 & 10,0 & - & - & - & - & - & - & - & - & 11 & 2,7 \\
\hline Nunca precisou & 13 & 4,7 & 1 & 10,0 & 1 & 1,6 & 1 & 4,7 & 1 & 2,8 & - & - & 17 & 4,1 \\
\hline Não confia/ não gosta/ maltratam & 5 & 1,8 & - & - & 2 & 3,2 & - & - & - & - & 1 & 16,7 & 8 & 2,0 \\
\hline Orientação médica para freqüentar a UNESP & - & - & - & - & 1 & 1,6 & - & - & - & - & - & - & 1 & 0,2 \\
\hline UBS sem médico, não atende, não faz exames & 2 & 0,7 & 1 & 10,0 & 1 & 1,6 & - & - & 2 & 5,6 & - & - & 6 & 1,5 \\
\hline Trabalha na UNESP ou parentes trabalham & 2 & 0,3 & - & - & 1 & 1,6 & - & - & - & - & - & - & 3 & 0,7 \\
\hline Tratamento só é feito na UNESP & 1 & 0,3 & - & - & 1 & 1,6 & - & - & 2 & 5,6 & - & - & 4 & 1,0 \\
\hline UNESP é mais confiável & 13 & 0,7 & - & - & 2 & 3,2 & - & - & - & - & - & - & 15 & 3,6 \\
\hline A UBS sempre encaminha para a UNESP & 1 & 0,3 & - & - & - & - & - & - & - & - & - & - & 1 & 0,2 \\
\hline Sem Informação & - & - & - & - & 1 & 1,6 & - & - & - & - & - & - & 1 & 0,2 \\
\hline Subtotal & 54 & 19,7 & 3 & 30,0 & 11 & 17,7 & 1 & 4,7 & 6 & 16,7 & 1 & 16,7 & 76 & 18,5 \\
\hline Não se aplica & 221 & 80,3 & 7 & 70,0 & 51 & 82,3 & 20 & 95,3 & 30 & 83,2 & 5 & 83,3 & 334 & 81,5 \\
\hline Total & 275 & 100,0 & 10 & 100,0 & 62 & 100,0 & 21 & 100,0 & 36 & 100,0 & 6 & 100,0 & 410 & 100,0 \\
\hline
\end{tabular}

SMP = Sede de módulo assistencial e Pólo.

AdsMP = Adscritos ao município sede de módulo assistencial e Pólo.

$\mathrm{SM}=$ Sede de módulo assistencial

AdsM = Adscritos a municípios sede de módulo assistencial

Outros $=$ Municípios de outras regiões

$\mathrm{SI}=$ Sem informação 
Nesta tabela verifica-se que há pacientes que só procuraram serviços de saúde quando doentes, e a escolha do serviço recaiu sobre o atendimento hospitalar terciário.

Referiram nunca ter precisado de assistência médica, 17 pacientes $(22,4 \%)$.

Parte dos entrevistados, 14 casos $(18,4 \%)$, que não freqüentam serviços de saúde locais, denotam rejeição ao atendimento em Unidades básicas, alegando falta de confiança, falta de médicos, não gostar do atendimento, não ter possibilidade para fazer exames e até mesmo por "maltratar" os usuários.

Visando à complementação e entendimento das informações, foram realizadas entrevistas não estruturadas com 30 pacientes que buscaram atendimento no Pronto Socorro da UNESP. Dentre as várias perguntas formuladas a esses entrevistados, uma questão apresentada, visando conhecer as razões para não freqüentarem os serviços de saúde municipais, foi:

Você costuma freqüentar algum serviço de saúde na sua cidade?

\section{Quadro Síntese das Idéias Centrais}

\begin{tabular}{|l|l|}
\hline A & Freqüento Centro de Saúde Escola e cles atendem bem. \\
\hline B & $\begin{array}{l}\text { Freqüento serviços terciários porque o Posto de Saúde é muito tumultuado e } \\
\text { eu não tenho convênio. }\end{array}$ \\
\hline C & Freqüento os serviços locais, mas lá eles não atendem muito bem. \\
\hline D & Eu freqüento o Postinho e gosto muito. \\
\hline E & Não tive necessidade de procurar serviços de saúde locais. \\
\hline F & Procuro a UNESP em casos graves ou a UNIMED. \\
\hline
\end{tabular}

A - Freqüento o Centro de Saúde Escola e eles atendem bem (P1, P11, P14, P16, P21, P30).

Eu moro em Botucatu, então eu freqüento o Centro de Saúde Escola e freqüento a faculdade porque eu faço o relaxamento na faculdade às terças-feiras. E eu gosto muito, me dou muito bem. Não tenho reclamação nenhuma. Nem de um, nem do outro. O Centro de Saúde Escola é excelente, vou eu e a familia toda também.

Às vezes que precisei, sempre fui muito bem atendido. Não sei se foi sorte, mas sempre foi muito bom no Centro de Saude Escola. Toda vez que precisei, inclusive minha filha passou mal essa semana na escola e nós fomos lá, e a gente pediu por favor e a médica atendeu prontamente ela. Olha, o atendimento das pessoas lá, eles 
atendem muito bem tudo, o que eu reclamo é da parte das consultas que demora muito, você marca um ginecologista hoje, só tem pra uns 4, 5 meses.

\section{B - Freqüento serviços terciários porque o Posto de Saúde é muito tumultuado e eu não tenho convênio. (P2, P7, P24, P26, P27).}

Sim,(freqüento) o Pronto Socorro aqui da cidade de Botucatu. A questão é que eu não tenho convênio, meu serviço não tem nenhum plano de sáude e questão também da qualidade. Todas as vezes que eu vim aqui fui super bem atendida, não teve nenhum problema. Fui atendido numa coisa grave. Resolvi assim, às vezes resfriado, ai passei pelos médicos. Fiz um trabalho na hematologia, questão de anemia mesmo, fiz tratamento, deu tudo certo, fiquei um ano fazendo exames e, parcialmente, me recuperei. Onde eu venho é aqui na UNESP, procuro sempre aqui agora.

O posto de saúde é muito tumultuado, ultimamente eu não estava indo em nenhum. Da última vez que eu fui, foi em Jaguariúna, mas lá o atendimento é horrivel. Muita gente, muito tumulto. A pessoa lá, o ambiente já não é muito agradável, sujo também, um pouco sujo. Também falta médico, médico atrasa para chegar, marca para duas horas, vai chegar duas e meia três horas. Assim por diante. Então, levo ele no Pronto Socorro. E lá é bom. Não levo ele em São Manuel porque lá não tem recurso assim. Igual aqui não. Criança, geralmente aqui é melhor.

Eu também freqüento bastante o P.S da cidade, o pronto socorro, a gente faz vários atendimentos, tanto na parte de medicamentos, agora que eu fiz a cirurgia eu estava fazendo 3 vezes por dia curativo. Faço acompanhamento de rotina aqui na Unesp e no HC em São Paulo. Em São Paulo a parte de reumatologia e aqui na Unesp a parte óssea de reumatologista.

\section{C - Freqüento os serviços locais, mas lá eles não atendem muito bem (P3, P4,} P10, P12, P15, P18, P19.).

Costumo ir no posto de saúde e na Santa Casa. Só que lá é pouco atendimento. Não o recurso, mas deles atenderem com mais atenção, se precisa de uma sonda, uma 
fralda, eles me arrumam, só que me arrumam bravos, meio nervoso. Às vezes minha mulher precisa dar um banho em mim... eles acham ruim de eu ficar internado. $\dot{E}$, costumo ir em hospital lá em Pardinho, mas geralmente é aqui. Levo o nenê no hospital e no posto de saúde. Mas lá eles não atendem muito bem. A chefe lá maltrata a gente. A gente fica lá até tarde, depois eles às vezes nem examina direito e já passa a receita. A minha outra netinha está com hérnia há 5 anos, não resolverain nada. Quando marca, vai lá, não vem o médico, tem que voltar marcar de novo.

Não é sempre que eu posso, mas de vez em quando, quando eu tenho tempo porque, também, para você conseguir uma vaga lá, você tem que ir às 4 horas da manhã, 5 horas, para você fazer uma ficha às 7 horas para atender logo às 9, 10 horas. Então quando a gente tem tempo de ir, eu vou. $O$ atendimento clínico geral, atendimento geral lá em São Manoel, no posto de saúde de lá, às vezes o médico chega tarde, não tem horário certo para chegar. Tem uns que, numa época que eu fui lá, teve um médico que era para chegar às 4 horas da tarde, ele chegou às 7 horas. Chegou bem atrasado, não é? Também depende do paciente saber conversar, também. E outra coisa também é que às vezes eles não olham para você direito, não olham para sua cara... eu fui lá ele já olhou para a minha cara e assinou lá e me deu isso aí, sem fazer nada.

No posto de Vitoriana a pediatria é muito dificil, porque é duas vezes por semana, terça e quinta, só que é muita criança para ser atendida, muita criança doente, então não tem vaga. Ela começa atender a meio-dia e vai até às 5 h, não tem vaga mesmo, então vacê tem que procurar outro tipo de atendimento quando tem uma criança doente. Você tem que procurar acudir aqui mesmo.

O Posto de Saúde da COHAB 1, o atendimento lá é péssimo. Bom, a gente tem que chegar lá às 6 h da manhã para conseguir, se conseguir, uma consulta para às 10h30 da manhã e, ainda, o médico fica 2 minutos com você, ele não te examina, tanto é que eu passo no ginecologista, ele nunca me examinou. O clinico geral até que é mais ou menos, mas assim, ele começa, dá certo, mas dai tem muita coisa que a burocracia é lá na frente, para você fazer exame demora 2, 3 meses. E outra coisa, comigo já aconteceu de vários exames serem trocados. Eu fiz um teste de gravidez há cinco meses atrás, deu positivo. Eu entrei na maior... fiquei assustada, dai eu vim 
para cá, eu não estava grávida. E agora, que faz 3 meses que está atrasado, deu negativo e o médico está achando que realmente eu estou grávida, só que ninguém atende.

D - Eu freqüento o Postinho e gosto muito (P5, P6, P22, P23, P25, P28, P29).

Ah, o postinho perto de casa. É bom lá. Os moços são muito educados, eu gosto muito. O posto de saúde do Jardim Cristina é bom, ótimo. O neném também levo lá, o atendimento da pediatria também é bom.

Eu freqüento aqui a Unesp e o posto de Rubião Junior. Também freqüentava o Centro de Saúde Escola. Agora fui transferida para cá e a gente freqüenta o posto de Rubião. O Posto, todas às vezes que procurei fui atendida. Foi marcada a consulta. Fui atendida e já encaminhou para o posto da outra cidade, para o posto da avenida para procurar a ortopedia e eles te orientam, te dão o remédio. Sempre que eu procuro, eles me dão remédio. Faço tratamento de pressão alta e eles também fornecem o remédio de pressão alta para mim sempre que eu precisei. Faço tratamento de anemia, eles fornecem também o remédio que eu tomo. E medicamento eu quase não tenho comprado.

\section{E - Não tive necessidade de procurar serviços de saúde locais (P8, P9, P13).}

Não, não preciso. Por enquanto não. É a primeira vez, não tive a necessidade ainda, sabe. Só exame de vista no médico particular...

\section{F - Procuro a UNESP em casos graves ou a UNIMED (P17, P20).}

Quando tem algum acidente grave é aqui na Unesp. Fora isso vou também na UNIMED.

Os pacientes que não freqüentam Unidades Básicas ou freqüentam, mas preferem o Serviço de Urgência/Emergência da UNESP alegam o mal atendimento recebido nas UBSs, quanto ao:

- Ambiente - Citado como desagradável, sujo e tumultuado. 
Observam-se em algumas Unidades Básicas e Hospitalares dos municípios da região a precariedade das suas instalações, falta de manutenção e reparos nos prédios, no mobiliário, nos equipamentos e nos materiais usados na assistência. Também são muito usados cartazes para comunicações e informações aos usuários, colados nas paredes, que com o tempo vão se deteriorando, dando um aspecto de "favelização" ao ambiente.

- Esquema de funcionamento - As filas para o atendimento começam a se formar de madrugada; falta de recursos materiais; falta de médicos; não observância dos horários de atendimento aos usuários.

Além da desatenção histórica que penaliza os doentes pela longa espera nas filas para serem atendidos, continuam sendo adotadas normas e rotinas pouco flexíveis e muitas vezes mais em função de interesse do serviço e de seus agentes do que em função dos interesses dos usuários.

- Atendimento médico - Não observam o cumprimento dos horários de consultas; não examinam adequadamente; comunicam-se de modo deficiente com os usuários.

Especialmente nas Unidades Básicas de Saúde, dadas as suas características, os vínculos da relação médico/usuário deveriam ser muito firmes, no entanto, os usuários apontam a falta do compromisso e do envolvimento médico.

Em revisão de artigos publicados sobre o tema "Utilização de serviços de saúde" feita por MENDOZA-SASSI e BÉRIA (2001), foram citados estudos que indicaram o fato de existir um local definido e um médico definido para o atendimento como um dos fatores mais importantes na utilização de serviços de saúde. Quando isto ocorre, a utilização de serviços de emergência por motivos realmente urgentes foi também observada. Depois de ajustar para outras variáveis (demográficas, socioeconômicas, seguros de saúde e número de enfermidades crônicas) o estudo de SOX et al (1998) citado por MENDOZA-SASSI e BÉRIA (2001) demonstrou que a categoria sem médico definido se associou significativamente com a utilização de serviços de emergência. A pesquisa de ALPERT et al. (1970) também citada por MENDOZA-SASSI e BÉRIA (2001) encontrou que crianças com médico definido realizam mais consultas preventivas $\mathrm{e}$ menos por enfermidades. Também foi mencionado um estudo envolvendo pessoas 
com 55 anos ou mais, que receberam cuidados do mesmo médico durante 18 meses de seguimento. Estas tiveram menor número de internações de emergência e período de internação mais reduzido.

Os depoimentos dos entrevistados apontam para a necessidade de adoção de medidas que visem ao estabelecimento do médico definido para a assistência aos usuários, em número suficiente, compativel com a demanda e com competência, científica, técnica, moral, além da capacidade de relacionamento interpessoal.

- Relacionamento entre profissionais de saúde e usuários - Citado maus tratos.

Falas do tipo: "... se precisa de uma sonda, uma fralda, eles me arrumam só que me arrumam bravos..."; "a chefe de lá maltrata a gente" denunciam atitudes reprováveis por parte de profissionais de saúde, as quais revelam descompromisso com o serviço e abuso de poder.

Fala-se muito em acolhimento, humanização do atendimento, direitos dos usuários, porém, ainda há resistências às mudanças nas concepções tradicionais fortemente autoritárias, persistindo comportamentos inaceitáveis nas relações dos profissionais com os usuários.

Em março de 1999 a Assembléia Legislativa do Estado de São Paulo aprovou a lei $n^{\circ} 10.241$ que dispõe sobre os direitos dos usuários dos serviços e das ações de saúde no Estado (CONSELHO REGIONAL DE MEDICINA DO ESTADO DE SÂO PAULO, 1999). Esta lei representou importante avanço para a superação do paternalismo na relação entre profissionais de saúde e usuários, entretanto, a ampla divulgação, pelos serviços de saúde, desses direitos garantidos em lei, ainda está a merecer a devida consideração.

Os usuários que mencionaram freqüentar as Unidades Básicas do município e gostar do atendimento recebido utilizaram os seguintes critérios: tempo de espera; relacionamento com os profissionais e recebimento de medicações. Isto revela a importância que tem para o usuário o seu acolhimento pelo serviço de saúde.

O mau atendimento, o descaso, as práticas autoritárias, concorrem para o sucateamento dos serviços, para a sua desmoralização e a conseqüente rejeição dos usuários. As transformações nessa realidade devem implicar em alterações na organização, no gerenciamento dos serviços e nos comportamentos dos profissionais 
no sentido de reduzir a descortesia e a impessoalidade do atendimento e intensificar os vínculos entre profissionais de saúde e população. Enquanto essas mudanças não ocorrerem os serviços terciários continuarão sobrecarregados.

Quanto aos encaminhamentos, dos 410 pacientes entrevistados, 347 procuraram o PA e o SE espontaneamente e 63 foram encaminhados pelo município de residência, sendo 58 por Unidade Básica de Saúde, 2 por médico de empresa, 1 por médico particular, 1 pelo serviço de resgate (SPVIAS) e 1 sem informação. Destes 63 encaminhados 43 apresentaram carta de encaminhamento e 9 apresentaram os resultados de exames realizados.

Dentre os 347 entrevistados que procuraram o PA e/ou o SE espontaneamente, alguns apresentaram mais de uma justificativa para a procura espontânea. Essa procura foi explicada por $50(12,2 \%)$ entrevistados por razões econômicas e facilidades de acesso, 224 (54,6\%) a justificaram pela situação do município em que residem e 321 (78,3\%) entrevistados alegaram confiança no atendimento da UNESP.

Na tabela 9 são apresentados os motivos alegados, por 50 entrevistados, para a procura da UNESP por razões econômicas e facilidades de acesso. Alguns entrevistados citaram mais de uma razão.

Tabela 9 - Distribuição de freqüências absolutas e relativas na amostra de 50 pacientes, que citaram razões econômicas e facilidades de acesso para procura do serviço da UNESP, entrevistados no Serviço de Urgência/Emergência do HC - FMB, segundo razões apresentadas, Botucatu, março de 2002

\begin{tabular}{lcc}
\hline \multicolumn{1}{c}{ Razões } & $\begin{array}{c}\text { Freqüência } \\
\text { absoluta }\end{array}$ & $\begin{array}{c}\text { Freqüência } \\
\text { relativa }\end{array}$ \\
\hline Não tem dinheiro para buscar outro recurso & 24 & 45,3 \\
Aproveitou estar acompanhando uma pessoa & 18 & 33,9 \\
Residência próxima & 5 & 9,4 \\
Aproveitou vinda para fazer exames & 3 & 5,7 \\
Aproveitou condução de vizinho & 1 & 1,9 \\
Porque não pode perder dia de trabalho & 1 & 1,9 \\
Por estar passando nas proximidades da UNESP & 1 & 1,9 \\
\hline \multicolumn{1}{c}{ Total } & $\mathbf{5 3}$ & $\mathbf{1 0 0 , 0}$ \\
\hline
\end{tabular}


Dentre os que referiram razões econômicas e facilidades de acesso, a resposta mais freqüente foi "não tenho dinheiro para buscar outro recurso" ( 24 casos), na qual pode-se inferir que, se tivessem dinheiro, procurariam um outro serviço. É importante ressaltar que muitos pacientes procuraram o PA e o SE por mero acaso, aproveitando estar acompanhando outra pessoa, a vinda para exames, a condução de outras pessoas, ou, simplesmente, por estar próximo à UNESP. Funcionários do serviço comentam que esse tipo de demanda é freqüente e observam que na maioria dos casos não há o caráter de urgência nesses atendimentos, mas tratam-se de problemas de saúde que poderiam ser melhor atendidos em Unidades Básicas de Saúde.

Seria interessante tentar entender os condicionantes desse comportamento dos usuários. A quê estaria ligada a impossibilidade ou a falta de oportunidade para buscar assistência médica em um serviço de saúde mais próximo, em uma outra circunstância?

$\mathrm{Na}$ tabela 10 são apresentados os motivos alegados por $224(54,6 \%)$ entrevistados, referentes às condições dos serviços de saúde do município onde residem, para a procura dos serviços da UNESP.

Tabela 10 - Distribuição de freqüências absolutas e relativas na amostra de 224 pacientes, entrevistados no Serviço de Urgência/ Emergência do HC FMB, que apontaram motivos ligados à situação do seu município para procura do serviço da UNESP, segundo razões apresentadas, Botucatu, março de 2002

\begin{tabular}{|c|c|c|}
\hline Razões & $\begin{array}{c}\text { Freqüência } \\
\text { absoluta }\end{array}$ & $\begin{array}{c}\text { Freqüência } \\
\text { relativa }\end{array}$ \\
\hline Não conseguiram resolver seu problema & 68 & 21,9 \\
\hline O atendimento é demorado & 52 & 16,8 \\
\hline Não é bem atendido nos serviços do município & 49 & 15,8 \\
\hline Não fazem os exames que precisa & 46 & 14,7 \\
\hline Não há médicos na especialidade & 37 & 11,9 \\
\hline Não confia nos serviços do município & 35 & 11,3 \\
\hline As UBS não atendem sem agendamento & 8 & 2,6 \\
\hline Não havia médico (faltas, férias) & 6 & 1,9 \\
\hline A Unidade básica estava fechada & 3 & 1,0 \\
\hline Não conhece os serviços do município & 2 & 0,6 \\
\hline O serviço não tem medicamentos, nem laboratórios & 2 & 0,6 \\
\hline Necessita fazer Papanicolaou para receber o leite & 1 & 0,3 \\
\hline Não havia vacina anti-rábica no município & 1 & 0,3 \\
\hline Total & 310 & 100,0 \\
\hline
\end{tabular}

* respostas múltiplas 
Os motivos mais citados foram os relativos à: resolutividade, aspectos do atendimento (demora e mau atendimento), necessidade de realização de exames e falta de confiança no serviço.

Para melhor compreender os motivos que levaram os indivíduos a procurarem a UNESP, abordamos esta questão com os 30 pacientes entrevistados. Os Discursos do Sujeito Coletivo obtidos foram em resposta à questão:

Por que você decidiu vir a este Serviço de Urgência/Emergência?

\section{Quadro Síntese das Idéias Centrais}

\begin{tabular}{|l|l|}
\hline A & Eu passei muito mal. \\
\hline B & $\begin{array}{l}\text { Se não melhorar aqui não adianta ir para outro lugar. Atendimento, RX, já } \\
\text { faz tudo aqui e pronto. }\end{array}$ \\
\hline C & Sempre quando eu venho, venho aqui. \\
\hline D & O médico mandou porque lá não tinha como fazer o tratamento. \\
\hline E & $\begin{array}{l}\text { É o canal mais fácil para você chegar até o médico que você pretende se } \\
\text { tratar. }\end{array}$ \\
\hline F & Porque os acidentes são trazidos à UNESP. \\
\hline G & Porque o Posto de Saúde está fechado nesse horário. \\
\hline
\end{tabular}

\section{A - Eu passei muito mal (P1, P5, P9, P25, P28, P30).}

Há um tempinho eu estou precisando fazer uma consulta médica. Daí, essa semana, hoje, eu passei muito mal, com muita dor de cabeça, a pressão subiu mesmo e agora muita dor no peito, eu senti um pouco de tontura, embralhou as vistas, assim, essas coisas, a inflamação que eu estou sentindo não melhorou, e está cada vez pior, eu estou sem comer uns dois três dias, preciso melhorar, então procurei os médicos daqui, decidi passar hoje aqui, porque esse serviço é muito bom, né? Ai eu falei: Ah, acho melhor, né? Porque aqui faz tempo que eu venho. Já era para mim ter feito uns exames para cirurgia, só que dai esses exames eu não consegui, faz mais de dois anos e eu não consegui. Então eu desanimei. Eu vinha todos os meses: Ah, vem o mês que vem, vem no fim do mês, liga, liga... Então eu achei que começaram a me enrolar sabe, então eu não voltei mais atrás daquele exame. Fiquei quase um ano e meio procurando e eu não consegui. Falei, a hora que eu tiver, que eu sei o 
problema que eu tenho, que já era para mim ter operado na Misericórdia, há 6 anos atrás, mas como meu marido ficou doente... Eu tenho que esperar o dia que tiver com a dor bem forte para mim vir, dai eles já fazem os exames para ver o que vai ser decidido, ver se resolve dai, porque esse exame de dois anos atrás...E se eu fosse no postinho também não ia adiantar muito. Eles iam mandar eu vir para cá.

$B$ - Se não melhorar aqui não adianta ir para outro lugar. Atendimento, $R X, j a ́$ faz tudo aqui c pronto (P2, P3, P4, P8, P10, P13, P14, P15, P16, P17, P19, P22, P23, P24).

Eu não passei bem e vim consultar, passar por médico aqui, porque lá no posto eles falaram que só vai marcar depois de quarenta dias. Aqui o atendimento é melhor, eu vou ser bem atendido com certeza, é mais rápido, mais recolhido, mais prático, eles examinam melhora as pessoas, mais aprofundado o exame, não é? E a garantia bem melhor também. Vim consultar, passar por médico. Aqui é um bom atendimento que eu tenho aqui, eu acredito no que as pessoas dizem para mim. Se você não melhorar aqui, não adianta ir para outro lugar. Porque na minha cidade eu não tenho condições de fazer. Já não tenho condições de pagar. E a maioria dos exames que eu vim aqui é porque lá eu pago e aqui eu não pago nada. Atendimento... Raio X, já faz tudo aqui mesmo e pronto. $\dot{E}$ um dos melhores da região ou o melhor da região. Eu voltei no Posto, só que daí ele trocou o remédio, só que o remédio fez mal, e daí eu não voltei.

Não fui ao Centro de Saúde Escola porque eu acho que aqui é melhor. Porque eu já fui no Pronto Socorro do bairro e eu não gostei de ser atendida lá. Não gostei muito do médico... Sabe quando trata assim... como é que eu posso dizer?... não tratou bem a pessoa, né? Eu achei que ele foi... sabe assim, você chega, ele só pergunta e já passa a receita, não examina nada. Dai eu não gostei muito não. Por isso que eu vim aqui hoje. Eu ia lá, que é mais perto, Pronto Socorro também, dai falei, não, vou lá mesmo. Moro longe, gasto a passagem, mas eu vou lá que é melhor. E tem mais médicos, eles sabem mais. 
C - Sempre quando eu venho, venho aqui (P6, P26, P27).

A gente vem aqui porque minha mãe é cardiopata, ela fez cirurgia aqui na Unesp, colocou válvula no coração e ela tem bastante idade, mas os médicos diz que o pulmão dela está enchendo de água sempre e o coração está super crescido. Mas como ela está com 70 ano, ela não quer cirurgia e eu estou com um certo líquido no joelho e porque eu voltei a andar faz uns 3 dias, então está dando um certo inchaço no meu pé, então os médicos pediram para eu vir sempre. Sempre quando eu venho, venho aqui.

\section{D - O médico mandou porque lá não tinha como fazer o tratamento (P7, P12).}

O médico de lá mandou, que lá não tinha como fazer o tratamento do braço dele que lá não conseguiram por no lugar, então aqui tinha mais recursos.

Hoje eu passei ela no hospital e o médico falou que não ia por a mão porque ia ficar cicatriz, enião ele mandou para cá para fazer plástica.

E - É o canal mais fácil para você chegar até o médico que você pretende se tratar (P11, P18).

É porque eu acho que é o canal mais fácil para você chegar até o médico que você pretende se tratar ou que faz parte da sua doença. Eu não fui no Centro de Saúde Escola porque lá, pela informação que eu tive, não tem ortopedista e, talvez, o meu problema seja para passar pela ortopedia.

F - Porque os acidentes são trazidos à UNESP (P20).

Ah, porque agora é mais rápido e mais perto também, eu preferi vir aqui. Acidente geralmente eles trazem aqui, né? Porque na Unimed tem que abrir cart...(inaudivel) então eu não queria, então eu preferi vir aqui.

G - Porque o Posto de Saúde está fechado nesse horário (P21, P29). 
Porque é a Unesp que a gente recorre sempre. Porque posto de saúde que a gente vai está sempre fechado nesse horário, então tem que ser a Unesp.

Os discursos destes entrevistados coincidem com os dados obtidos nas entrevistas estruturadas. Falam da busca do serviço de Urgência /Emergência da UNESP devido ao mal atendimento na UBS “... ele só pergunta e já passa a receita, não examina" ou falta de resolutividade "trocou o remédio, não deu certo" ou "só vão marcar a consulta depois de 40 dias" e também à falta de recursos (exames, Raio X, especialistas).

É acrescentada a informação de que a procura pelo Serviço de Urgência/Emergência da UNESP é feita com o objetivo de facilitar o acesso a uma consulta com o especialista. Sabe-se que para conseguir esse tipo de consulta é preciso passar pela Triagem de Especialidades, a qual tem um sistema de quotas para os municípios, que são consideradas insuficientes. Essa via é, portanto, demorada. O usuário descobre, então, uma outra via alternativa que tem se revelado mais rápida. Ao ser atendido no serviço de urgência e não sendo caracterizada a emergência, mas reconhecida a necessidade de atendimento por especialista, esse especialista poderá ser chamado para uma atendimento inicial e, na maioria das vezes, agendará um retorno ao ambulatório da especialidade. No caso do especialista não ser chamado, será agendada consulta na Triagem ou no Ambulatório da especialidade, pelo médico do serviço de urgência, abreviando, deste modo, a espera pela vaga.

Sobre essa atitude dos usuários, observa-se uma tendência, entre prestadores de cuidados e gestores, de culpá-los, responsabilizando-os por distorções no sistema, sem o entendimento de que as distorções do sistema é que geram as buscas alternativas. Afinal, trata-se da luta pela redução da dor, do sofrimento e pela sobrevivência.

Outros discursos dos usuários parecem indicar alguma influência da pregação feita, especialmente pela iniciativa privada, veiculada nos meios de comunicação, sobre segurança e eficiência atrelada ao uso da alta tecnologia. Deste modo, sentemse seguros somente em serviços que dispõem de aparato tecnológico avançado. 
Dentre os entrevistados, $321(78,3 \%)$ referiram maior confiança no Serviço de Urgência/Emergência da UNESP, citando um ou mais motivos para tal confiabilidade. Os motivos são apresentados na tabela 11.

Tabela 11 - Distribuição de freqüências absolutas e relativas na amostra de 321 pacientes, que apontaram motivos ligados à confiança depositada na UNESP para procura dos seus serviços, entrevistados no Serviço de Urgência/Emergência do HC - FMB, Botucatu, março de 2002

\begin{tabular}{lcc}
\hline Motivos para confiança no serviço da UNESP & $\begin{array}{c}\text { Freqüência } \\
\text { absoluta }\end{array}$ & $\begin{array}{c}\text { Freqüência } \\
\text { relativa }\end{array}$ \\
\hline Resolve melhor os problemas & 122 & 25,6 \\
Experiência anterior bem sucedida & 87 & 18,2 \\
Tem mais recursos para exames & 81 & 17,0 \\
Possibilidade de consulta a vários especialistas & 70 & 14,7 \\
Atendimento mais rápido & 66 & 13,8 \\
Está em seguimento na UNESP & 15 & 3,2 \\
Residência próxima & 10 & 2,1 \\
Estuda, trabalha ou tem parentes na UNESP & 8 & 1,7 \\
Indicação médica & 5 & 1,0 \\
Não especificaram & 4 & 0,8 \\
Funcionamento ininterrupto & 2 & 0,4 \\
Não conhece outros serviços de urgência & 2 & 0,4 \\
Conhece vários médicos da UNESP & 2 & 0,4 \\
A ambulância leva direto para a UNESP & 1 & 0,2 \\
É o mais indicado da região & 1 & 0,2 \\
\hline \multicolumn{2}{c}{ Total } & $\mathbf{4 7 6}$ \\
\hline
\end{tabular}

Novamente aqui, os motivos citados foram os referentes à resolutividade $\mathrm{e}$ aos recursos existentes para o atendimento, além de experiências anteriores bem sucedidas e o fato do atendimento ser mais rápido.

O coletivo dos gestores argumenta sobre a confiança que os usuários depositam na UNESP respondendo a pergunta:

Neste estudo que realizamos, os pacientes entrevistados fizeram muitas referências à confiança que depositam na UNESP. A que você atribui isto? 


\section{Quadro Síntese das Idéias Centrais}

\begin{tabular}{|l|l|}
\hline A & $\begin{array}{l}\text { Quando você é atendido, você acaba fazendo o seu diagnóstico. E não resta } \\
\text { outra alternativa. }\end{array}$ \\
\hline B & A UNESP tem mais recursos, aqui é benzimento. \\
\hline C & $\begin{array}{l}\text { A confiança, o hospital escola adquiriu com as pessoas pela quantidade, } \\
\text { pelos equipamentos e pelo pessoal que eles têm. }\end{array}$ \\
\hline D & $\begin{array}{l}\text { Se a UNESP atende bem os casos que são graves, vai atender bem também o } \\
\text { que não é. }\end{array}$ \\
\hline E & A porta da UNESP continua aberta. \\
\hline F & Para se entregar a um tratamento a gente tem que confiar. \\
\hline G & $\begin{array}{l}\text { As vezes a UNESP que não orienta o paciente para retornar ao nosso } \\
\text { Serviço. }\end{array}$ \\
\hline
\end{tabular}

A - Quando você é atendido, você acaba fazendo o seu diagnóstico. E não resta outra alternativa $(\mathrm{G} 1, \mathrm{G} 4)$.

O conceito que a população tem do hospital é o de que é um hospital de nivel de atendimento bom. Quer dizer, demora, mas você é atendido e quando você é atendido você acaba fazendo o seu diagnóstico, isso é uma questão. Outra questão é a seguinte: não resta outra alternativa. Porque se você já esgotou o nivel primário e não conseguiu resolver o seu problema, o que resta, basicamente, é o nível terciário mesmo. Se os municipios atenderem melhor, o acolhimento da população for melhor, eu não preciso ir para Botucatu, porque as pessoas não reclamam. Porque não têm saída também, não adianta ela reclamar. Se ela não for lá para ser atendida ela vai morrer, porque ela não tem onde realmente ser atendida.

B - A UNESP tem mais recursos, aqui é benzimento (G2, G5, G7, G8, G16, G17).

Quando eles falam que têm mais confiança na Unesp não quer dizer que eles não confiam no nosso sistema, ou no profissional por questão de ética, essas coisas. Eles têm maior confiança na Unesp porque sabem que se lá ele precisar de um cardiologista, eles têm, se precisar de um reumato, eles têm, se precisar de uma ressonância magnética eles têm porque a Unesp tem um serviço de altíssima qualidade. 
Eu acho que essa sensação de estar sendo bem atendido, em parte, pode ser atribuida a agilidade do atendimento e a agilidade dos exames laboratoriais, porque você tem tudo no mesmo serviço. Você precisa de um raio $x$, você vai para o raio $x$, depois volta para o pronto atendimento e na hora ele decide se confirma o diagnóstico ou não. Na rede básica você não tem essa agilidade. Tem que marcar o exame, você tem que se dirigir a um outro serviço, se faz algum exame bioquímico demora um tempo absurdo para retornar. Mas em termos de qualidade dos profissionais, eu não sei se existe tanta diferença.

O que acontece quando você vai para o particular? Você vai na consulta, ele te receita, te dá um pedido de exames e pede um retorno, tal dia a senhora retorna. Eu acho que é isso.

A Unesp, como ela tem exames complementares, como ela tem vários tipos..., os diagnósticos deles às vezes são mais precisos, porque eles têm mais recursos... $O$ médico daqui sabe fazer, só que os exames complementares dependem da Unesp. E às vezes, o que o médio acaba diagnosticando no exame fisico, a Unesp já vai com os exames complementares, então dá mais confiança ao paciente. Às vezes, você pode até fazer o mesmo diagnóstico, mas lá, porque fez o exame e comprovou que ele estava ali na mão dele, é muito mais confiável do que o médico que trabalha só com o básico, que é a medicina normal.

Porque aqui, como eu estava falando para a senhora, aqui a demanda é grande e não tem muito tempo...é benzimento, vamos dizer a verdade, não tem aquele exame clínico bem feito com o paciente, de por a mão no paciente, então a gente nota que essa é a dificuldade. Fazer o paciente retornar, isso é importante. Muitas vezes porque ele (o médico da UBS) tem muito paciente, nem pede esse retorno: você vai tomar esses medicamentos e vai melhorar. Ele nem pede para você retornar.

C - A confiança, o hospital escola adquiriu com as pessoas pela quantidade, pelos equipamentos e pelo pessoal que eles têm (G3, G6, G9, G11, G12, G13, G15).

Olha, o hospital está, há trinta, quarenta anos. Isso tem que ter uma história. Segundo, que ele sempre procurou mesmo estar, do ponto de vista tecnológico 
humano, adequado às suas intenções de atendimento. Outra que eu acho que o que diferencia este hospital dos outros é o fato dele ter aluno, ter residente. Se ao mesmo tempo isso cria alguns problemas, ele na realidade é o grande fator renovador desse hospital. Eu acho que hospital que tem entre as suas caracteristicas o ensino e a pesquisa, é um hospital que, obrigatoriamente, faz com que os membros que trabalham nele permanentemente, procurem estar de uma certa maneira renovados. A crítica que eu faço é que esse não devia ser um hospital de ensino, na minha opinião deveria ser um hospital com ensino. Então eu acho que essa confiabilidade foi o próprio hospital escola que adquiriu com as pessoas, pela quantidade, enfim por tudo, pelos os equipamentos, pelo pessoal que eles têm lá. Então eu acredito sim que pessoas acabam indo lá por se sentirem mais seguras, por estarem num hospital com grandes condições de estar resolvendo.

Eu acredito até que foram casos para o serviço terciário, tiveram a atenção devida, tiveram seus problemas resolvidos e por isso passaram a confiar no serviço, lógico. E quando eles têm um problema menor eles acham que: - Ah, eles já me conhecem lá, eu já tenho um prontuário lá, já fica mais fácil porque eles já conhecem a minha história. $\dot{E}$, os casos graves vão lá e, muitas vezes, as pessoas se pautam nos casos graves, falam: - Bom, se no caso grave a pessoa voltou boa, porque o meu problema que não é lão grave eles não vão me curar? Então, uma faculdade de medicina, uma Unesp, por si só, já é um marco, já é um atrativo.

\section{D - Se a UNESP atende bem os casos que são graves, vai atender bem também o que não é (G4, G14).}

Olha, todos os pacientes que passam por aqui, até eu fiz isso de investigar por curiosidade, porque os pacientes sempre tratam de indicar que a consulta e a eleição de tal médico é a única e é a melhor que tem, então eles chegam aqui e falam: - Oi, senhor, eu toda a vida vim com o senhor, toda a vida o senhor me tratou, estou querendo que o senhor me encaminhe, estou querendo que o senhor me faça isso, me dê um atestado para aposentadoria. - E você está revisando a ficha, ele nunca passou com você, mas ele fala que passou contigo, e eles estão falando que você é o melhor que tem, é o melhor que existe, que nunca consultou com outro. 
Então quando lá na UNESP eles falam isso, eu vejo que aqui está repetindo também todo o dia. Sem tirar, lógico, que a Unesp é uma faculdade de respeito, uma faculdade que conta com professores de um certo gabarito e que, lógico eles têm como referência, tem que se pensar também que de fato lá é um centro excelente para tratamento.

Mas é uma questão cultural. Eu acho que ela é irreversível, mas ela pode ser amenizada. É a mesma coisa que a gente dizer assim, eu estou com um problema cardiológico, mas se eu for atendida no Eistein, eu vou me achar super protegida. $\dot{E}$ uma coisa cultural, não tem muito como mudar essa questão.

\section{E-A porta da UNESP continua aberta (G4).}

A agravante dessa situação é o comodismo da região. Eles se acomodaram, porque para todo mundo, o discurso que você vai ouvir, do motorista, do prefeito, do padre, da imprensa, de todo mundo, é que se eu tiver que morrer, que eu morra na Unesp, isso está dado regionalmente. Porque a porta da Unesp continua aberta, ela não entrou no sistema. Tem um agravante também, porque tem muitos residentes dando plantão na região, são eles mesmos que furam toda a hierarquia, eles põe os pacientes deles lá dentro, aonde eles quiserem colocar e tem uma Central de Regulação, que regula urgência e emergência e eu não consigo vaga pela Central de Regulação.

\section{F - Para se entregar a um tratamento a gente tem que confiar (G10, G17).}

Tem profissionais e profissionais... E eu tenho muitos problemas com profissionais. Assim: - Ele não conversa comigo, ele não olhou para mim, ele não verificou minha pressão... Queria que ele me examinasse. - Então, a gente tem essa dificuldade mesmo. Eu tenho profissional que realmente... Ele já é profissional antigo, o único especialista que eu tenho e as pessoas não querem, não querem e fazem de tudo para irem embora e procurar outro serviço. Acho, também, que às vezes o paciente não simpatiza com o médico e ele acaba querendo sair fora mesmo. Para se entregar a um tratamento a gente tem que confiar mesmo, eu procuro trazer médicos, porque os 
efetivos têm que ficar mesmo porque são efetivos, agora os que a gente contrata, a gente procura trazer alguém mais jovem, porque geralmente os médicos da rede são mais antigos. E a gente procura trazer um mais jovem, que está assim, a todo o vapor, no início de sua carreira. Um exemplo, esse ginecologista que está conosco, ele vem e tem aquela vontade de trabalhar e pede os exames, então ele passa essa segurança, porque os pacientes quando o médico pede os exames, pede o retorno do paciente, isso é importante, mas geralmente os médicos não pedem para retornar.

\section{G - Às vezes a UNESP que não orienta o paciente para voltar ao nosso Serviço (G12, G17).}

Na Unesp vai sim muita gente, e a própria Unesp deveria estar orientando para que eles viessem procurar, ou então entrassem em contato conosco para saber... Às vezes a Unesp que não orienta o paciente para voltar ao nosso serviço. A partir do momento que ele tem confiança lá, ele pode muito bem vir aqui e passar a ter confiança no médico daqui do municipio. Então, acho que falta um pouquinho da gente tentar saber quem é o médico lá, o nome desse paciente que está indo lá, tendo o nome dele aqui, nós iriamos atrás tentar trazer esse paciente para o nosso médico aqui do municipio.

Os gestores discutem a confiança que os entrevistados depositam no serviço do $\mathrm{HC}$ - FMB, reconhecendo como verdadeiros os aspectos apontados pelos usuários - a UNESP tem mais recursos, mais facilidade para exames e maior resolutividade. Referem também a importância de um hospital universitário para a população, dadas as suas características de assistência, pesquisa e ensino, pela idéia que transmitem de competência, atualização e renovação.

Ao compararem os serviços da UNESP com serviços de saúde de atenção básica e secundária existentes no município, falam de diferenças no atendimento, comentando que na UNESP é feito um exame físico mais detalhado e em geral, após o atendimento, é solicitado um retorno do paciente para avaliação, o que não é feito nos serviços de saúde do município, devido à incompatibilidade entre demanda e 
recursos existentes para o atendimento. Embora o número de serviços de saúde, de acordo com MENDES (2001), tenha crescido a uma taxa mais elevada que a da população, e a taxa de crescimento dos empregos estatais tenha sido quase o dobro dos empregos nos serviços de saúde privados, esse crescimento não é suficiente para atender a demanda de modo a garantir a universalidade do acesso. Entendem, ainda, os gestores entrevistados, que muitas das deficiências dos serviços de saúde da região são explicadas por uma acomodação dos municípios em face da abrangente atuação do HC - FMB.

O tipo de atuação ou postura que o HC - FMB assume na região, mantendo, no Serviço de Urgência/Emergência, suas portas abertas para atendimentos de todos os niveis de complexidade, agindo de modo independente, como se não fizesse parte do sistema, recebendo doentes de outros municipios e não retornando informações sobre o atendimento prestado, além de, em inúmeros casos, assumir definitivamente os cuidados de saúde dos usuários, mesmo daqueles que poderiam ser acompanhados em UBSs, tem propiciado distorções no sistema regional.

Os gestores também entendem que a confiabilidade no serviço da UNESP pode ser questionada, considerando ser o único serviço com condições de atender os casos mais complexos na região, não restando alternativa para os usuários do SUS.

A intensa participação do hospital universitário na região de Botucatu, ao longo de mais de 30 anos, vem exercendo influências nos profissionais de saúde e na população, do modelo centrado na dimensão biológica e tecnológica sobre as concepções relativas ao processo saúde/doença.

A assistência à saúde prestada, especialmente nos hospitais universitários, segue quase que exclusivamente esse tipo de modelo, no qual a doença é vista apenas como um processo biológico, sendo atribuição médica a identificação de sinais e sintomas que, com o auxilio da chamada propedêutica armada, permitirão o estabelecimento do diagnóstico e a definição do tratamento.

Deste modo, usuários e profissionais de saúde passam a conceber que serviço de saúde confiável é o que solicita muitos exames e dispõe de alta tecnologia, porque geram diagnósticos mais precisos e tratamentos mais eficazes.

De acordo com OLIVEIRA (2002) “comunidade dos usuários e serviços de saúde são construções culturais e estas influenciam-se reciprocamente". 
Essa reciprocidade, no entanto, é assimétrica, dadas as relações de poder entre os envolvidos (FOULCAUT 1979; BOLTANSKI 1984).

Segundo BOLTANSKI (1984), o poder, para ser exercido, requer de seus detentores a posse do saber e de segredos inacessíveis aos dominados. $\mathrm{O}$ uso corrente de uma terminologia rica em vocábulos técnicos complicados, neologismos e um linguajar típico do meio médico, especialmente no meio hospitalar acadêmico, na comunicação dos profissionais com os usuários, revela aspectos de domínio e poder. Esse poder, que é exercido com autoridade e paternalismo, leva a mudanças, nem sempre as mais apropriadas, de comportamentos diante da doença, de escolhas quanto ao tipo de atendimento médico e de avaliação dos resultados desse atendimento.

Por outro lado, a influência da comunidade dos usuários sobre os serviços de saúde tem um peso menor, dadas as suas reduzidas chances de participação e de se fazer ouvir por profissionais cuja formação não tem propiciado o aperfeiçoamento da sensibilidade para identificar a importância das histórias de vida, suas condições e as raízes das doenças.

Gestores um pouco mais fatalistas consideram essa situação irreversível. Entretanto, esta realidade não pode subordinar as ações humanas de modo a que não se possa modificá-la. Isto significaria a completa subordinação à "lei do mais forte" e a perda da liberdade.

Dentre os entrevistados, $182(44,4 \%)$ referiram ter procurado, antes de chegar à UNESP, outros serviços de saúde para resolução do problema atual, alguns, inclusive, mais de um serviço e $228(55,6 \%)$ não procuraram.

A tabela 12 mostra os tipos de serviços procurados. 
Tabela 12 - Distribuição de freqüências absolutas e relativas dos tipos de serviços procurados para resolver o problema atual de saúde, na amostra de 182 pacientes entrevistados no Serviço de Urgência/Emergência do HC FMB, que referiram a procura de outros serviços, Botucatu, março de 2002

\begin{tabular}{lcc}
\hline \multicolumn{1}{c}{ Tipos de serviços de saúde } & Freqüência absoluta & Freqüência relativa \\
\hline UBS & 92 & 43,5 \\
Hospital Secundário & 73 & 34,5 \\
Hospital Terciário & 39 & 18,4 \\
Médico Particular & 5 & 2,4 \\
Atendimento médico domiciliar & 1 & 0,4 \\
Médico de Empresa & 1 & 0,4 \\
\hline \multicolumn{1}{c}{ Total } & $\mathbf{2 1 1}$ & $\mathbf{1 0 0 , 0}$ \\
\hline
\end{tabular}

Estes dados indicam maior procura por serviços de Unidades Básicas de Saúde, seguida por Hospital Secundário e Hospital Terciário. Os entrevistados citaram os serviços procurados, mas a classificação em UBS, Hospitais Secundários e Hospitais Terciários foi feita posteriormente pela autora. O maior percentual foi o de pacientes que não procuraram outros serviços de saúde para resolução dos seus problemas, tendo buscado primeiramente o Serviço de Urgência/Emergência da UNESP.

À guisa de complementação, é apresentado a seguir o Discurso do Coletivo dos pacientes sobre a questão:

Já procurou outros serviços ou outros profissionais para resolver este seu problema de hoje?

Quadro Síntese das Idéias Centrais

\begin{tabular}{|l|l|}
\hline A & Já, particular, mas é tão caro! \\
\hline B & É a primeira vez que eu venho. \\
\hline C & Já procurei, mas não resolveu nada. \\
\hline D & Já procurei outros serviços, mas me mandaram para a UNESP. \\
\hline
\end{tabular} 


\section{A - Já, particular, mas é tão caro! (P1, P30).}

Já, particular, mas o serviço médico é tão caro hoje em dia, que não dá para pagar uma consulta particular ou exames particulares, então preferi vir aqui para ver se consigo fazer um acompanhamento para descobrir o que, exatamente, é essa dor. Eu não tenho condições de pagar.

\section{B - É a primeira vez que eu venho ( P2, P6, P8, P10, P16, P18, P19, P20, P21,} P24, P25, P26, P28.).

Não, não procurei por falta de... assim também eu trabalho muito, então falo ah, daqui a pouco melhoro, então vai indo, vai indo, até que agora piorou. Eu decidi procurar quando ficou pior. É a primeira vez que eu venho, é a primeira vez que isso acontece.

Eu estava apenas com medicina alternativa, em casa, fazendo compressas, mas agora começo a apresentar problema, enião eu achei que devia procurar um especialista ou... eu quero no momento um clínico geral porque eu acho que o clínico geral vai me dar uma orientação sobre o que eu tenho de verdade. Porque começou agora, sabe. Porque a gente chega aqui, eles procuram fazer todos os exames. Foi o que agora não aconteceu. Então, quiseram encaminhar para o posto. Então, através desta consulta, eu peguei alguns nomes de médicos particulares, está aqui, olha. Não é questão de não confiar. É que eles queriam me mandar para o posto de saúde. Então, um negócio que apareceu agora, toda vida tive saúde. Eu vim aqui e aqui eles mandam para o posto de saúde, então...

Lá você tem que ir cedo para conseguir uma vaga e marcar. E lá também não tem um especialista, é sempre um clínico geral. E para você conseguir esse especialista, você tem que marcar também. E às vezes, naquela data marcada você não tem condições de ir por causa do trabalho ou você está fazendo outra coisa.

O problema é só aqui mesmo. Porque no hospital do bairro, eles vão tirar Raio $X$, mas não tem ortopedia, então tem que ser aqui na Unesp mesmo. 
C- Já procurei, mas não resolveu nada $(\mathrm{P3}, \mathrm{P} 4, \mathrm{P} 5, \mathrm{P9}, \mathrm{P} 11, \mathrm{P} 13, \mathrm{P} 14, \mathrm{P} 15, \mathrm{P} 23$, P27, P29).

Então eu vou no posto, ai eles dão antibiótico. Eu fui de manhã e voltei agora à noite. Porque de manhã ela deu amoxilina de comprimido e eu nunca dei comprimido é é de $500 \mathrm{mg}$, ai eu pensei: acho que isso aqui é para adulto, comprimido. Ai eu vim conversar com o médico, para ver se devia dar ou não. Daí ele passou o em pó, de vidro que eu já estou acostumada a dar para ele.

Então, èu fui... a primeira vez eu fui lá, ai eu fui a segunda vez que depois eles não deixaram eu consultar e aí eu vim aqui. Já o hospital Sorocabana, também não resolveu nada. Eu fui lá e eles só falaram que ele está com sapinho e lambém para eu dar soro para ele, da diarréia dele, mas... ah... não foi bom lá. $O$ atendimento foi péssimo, aqui é melhor.

A hora que eu falei para ele que eu estava atrasada fazia 3 meses, que eu queria saber o que eu tenho, ele mandou eu procurar um ginecologista. Simplesmente fez isso comigo.

Já ele, fez cirurgia de traqueostomia no Centrinho de Bauru. Foi muito bom. Agora está precisando fazer troca de cânula da traqueo. Eles lá marcam a data muito longa. Não dá para ser trocada lá. E também eles não fornecem o relatório dele para poder trocar aqui, com o pessoal da otorrino daqui da Unesp. Ontem mesmo eu estive lá. Perdi o dia lá. Não consegui nada. Hoje também eu vou ter que ir de novo. Eles aqui não trocam essa cânula, está precisando trocar. Eles não liberam o prontuário dele. Só neste pronto atendimento eu já passei umas cinco vezes já.

Eu venho atrás desse meu problema de saúde, que agora que foi descoberto que faz 12 anos que eu tenho esse problema e eu venho atrás disso já em tudo quanto foi hospital, já em Bauru, ai depois de lá eu já vim para a Unesp também, não descobriram o que eu tinha, ai eu fui para Bauru, paguei uma consulta, lá o médico me transferiu para São Paulo. Aí lá sim, eles descobriram o que eu tinha, em São Paulo que eles descobriram que era uma febre reumática, junto com artrite juvenil. Agora eu acompanho lá e aqui. 
D - Já procurei outros serviços, mas me mandaram para a UNESP (P7, P12, P17, P22).

Em Pardinho, o médico atendeu nós lá e não tinha equipamento, mandou nós para o Regional. Fui levado para o Regional. O Regional não teve... Fui lá no hospital e o médico falou assim, olha não vou por a mão, só tira o sangue e leva para a Unesp. Disseram que não era serviço deles, não tinha o tipo... nem o medicamento estava lá. Mandaram para a Unesp. Foi daqui que fui transferido. Só que o meu recurso primeiramente que tive quando sofri o acidente foi aqui que sai. Hoje me sinto um homem normal, um homem mais feliz. Porque foi a Unesp que me ajudou a viver.

Em sintese, dentre os usuários que não procuraram outros serviços encontram-se:

- aqueles que, se pudessem pagar, procurariam um serviço particular. Não podendo, procuraram a UNESP;

- aqueles que só procuram serviço de saúde quando doentes e, nessa condição, preferiram o serviço terciário;

- aqueles que já sabem que no serviço do seu município não tem as condições que julgam necessárias - especialistas e exames - e por isso buscaram o atendimento diretamente na UNESP.

Os usuários que procuraram outros serviços referiram:

- mal atendimento e não resolução do problema, o que motivou a ida à UNESP;

- encaminhamento pelo serviço de saúde para a UNESP, por falta de condições materiais e médicos para o atendimento.

Verifica-se que o padrão de uso dos serviços de saúde varia de pessoa para pessoa. Isto pode ser decorrente do grupo social a que pertencem, da sua ocupação e condições de trabalho, do seu grau de instrução, da sua percepção sobre a gravidade da doença, dentre outros fatores. Assim, há usuários tidos como freqüentadores obstinados de serviços de saúde e outros que só os procuram em situações de maior 
gravidade. Entretanto, os critérios para a escolha do tipo de serviço a ser utilizado recaem sobre o acolhimento e sobre as condições que podem indicar maior resolutividade e qualidade da atenção. Deste modo, quando os serviços de saúde, especialmente os primários e secundários, não estão atentos para estes aspectos, a aceitação, pelos usuários, do atendimento regionalizado e hierarquizado em níveis de complexidade crescente, dificilmente é conseguida e, como conseqüência, não é observada.

. No sentido de conhecer os meios que os usuários da região utilizaram para chegarem até o Serviço de Urgência/Emergência foi incluída, nas entrevistas estruturadas, a questão sobre o transporte usado para locomoção do local em que se encontravam até a UNESP.

O meio de transporte citado pelos entrevistados é apresentado na tabela 13.

Tabela 13 - Distribuição de freqüências absolutas e relativas na amostra de pacientes entrevistados no Serviço de Urgência/Emergência do HC - FMB, segundo o meio de transporte utilizado, Botucatu, março de 2002

\begin{tabular}{lcc}
\hline \multicolumn{1}{c}{ Meio de transporte } & $\begin{array}{c}\text { Freqüência } \\
\text { absoluta }\end{array}$ & $\begin{array}{c}\text { Freqüência } \\
\text { relativa }\end{array}$ \\
\hline Veículo próprio & 176 & 42,9 \\
Ônibus regular & 61 & 14,9 \\
Ambulância & 58 & 14,1 \\
Veículo emprestado & 57 & 13,9 \\
Veículo do município que traz doente para a UNESP & 39 & 9,5 \\
Veio a pé & 12 & 2,9 \\
Estava internado na UNESP, na alta sentiu-se mal & 3 & 0,7 \\
Disk Moto & 1 & 0,2 \\
UTI Móvel & 1 & 0,2 \\
Unidade de resgate & 1 & 0,2 \\
Viatura da polícia militar & 1 & 0,2 \\
\hline \multicolumn{2}{c}{ Total } & $\mathbf{4 1 0}$ \\
\hline
\end{tabular}

O maior percentual é de usuários que usaram veículo próprio $(42,9 \%)$ e ônibus regular de empresas particulares (14,9\%). As ambulâncias transportaram $14,1 \%$ dos entrevistados, indicando situações de gravidade maior ou de dificuldades de locomoção em veículos comuns ou mesmo por razões sociais. Estes resultados questionam a afirmação costumeira de que o grande volume de pacientes decorre da 
chamada "rebocoterapia", ou seja, do transporte de pacientes promovido pelos municípios. Observou-se que apenas aproximadamente 1/4 dos pacientes chegou ao $\mathrm{HC}$ transportado por veículos municipais.

En entrevista posterior com 30 pacientes que compareceram ao Serviço de Urgência/Emergência da UNESP foi-lhes apresentada a questão:

Qual o meio de transporte que utilizou? Quanto tempo levou desde sua saida até chegar aqui? Demorou?

Nos discursos dos pacientes observa-se que o veículo próprio foi muito usado e há concordância de que o tempo para chegar à UNESP não foi demorado. Porém, os que informaram o uso de veículo da prefeitura do municipio, espontaneamente disseram:

Ah! Demora um pouco, uma hora e meia, uma hora e vinte, é meio cansativo. A gente tem que ir na secretaria da saúde, às 6 horas para pegar o passe. Ás vezes não tem. Não tem uma condução adequada para viajar com a gente, principalmente no confortamento. As condução que eles traz, uma perua, não posso trazer acompanhante, entendeu? $\dot{E}$ condução com problema, quebrada, pode ter problema na estrada, a gente fica na estrada. A cadeira, não tem um lugar certo para por a cadeira. Então, fica dificil da gente vir. E essa perua está num estado... É da prefeitura, do fundo social que traz a gente. A gente depende do fundo social, de uma condução melhor, mas o estado da prefeitura não tem condições de dar para os pacientes uma condução melhor. Estamos precisando muito de uma condução.

Assim, verifica-se que, para ter direito à condução é preciso, também, entrar numa fila, madrugar, para receber o passe. Não se permitem acompanhantes e os doentes com limitações precisam contar com a solidariedade dos outros doentes ocupantes do veículo. O Discurso dos sujeitos aponta para a precariedade dos veículos, que podem colocar suas vidas em risco ainda maior.

Quanto ao tempo transcorrido entre a saída do local onde se encontrava e a chegada à UNESP, observa-se na tabela 14 : 
Tabela 14 - Distribuição de freqüências absolutas e relativas na amostra de pacientes entrevistados no Serviço de Urgência/Emergência do HC - FMB, segundo o tempo transcorrido entre a saída do local onde se encontrava e chegada à UNESP e município de procedência, classificado de acordo com o Plano Diretor de Regionalização, Botucatu, março de 2002

\begin{tabular}{|c|c|c|c|c|c|c|c|c|c|c|c|c|c|c|}
\hline \multirow{3}{*}{$\begin{array}{c}\text { Tempo } \\
\text { (em horas) }\end{array}$} & \multirow{2}{*}{\multicolumn{2}{|c|}{ SMP }} & \multicolumn{6}{|c|}{ Procedência } & \multirow{2}{*}{\multicolumn{2}{|c|}{ Outros }} & \multirow{2}{*}{\multicolumn{2}{|c|}{ SI }} & \multirow{2}{*}{\multicolumn{2}{|c|}{ Total }} \\
\hline & & & & lsMP & & SM & & dsM & & & & & & \\
\hline & $\mathbf{N}$ & $\%$ & $\mathbf{N}$ & $\%$ & $\mathbf{N}$ & $\%$ & $\mathbf{N}$ & $\%$ & $\mathbf{N}$ & $\%$ & $\mathbf{N}$ & $\%$ & $\mathbf{N}$ & $\%$ \\
\hline$<1 \mathrm{~h}$ & $259 *$ & 94,18 & 5 & 50,00 & 34 & 54,84 & 10 & 47,62 & 12 & 33,33 & 5 & 83,33 & 125 & 79,31 \\
\hline $1 \vdash 2$ & 10 & 3,64 & 3 & 30,00 & 20 & 32,26 & 8 & 38,10 & 13 & 36,11 & - & - & 54 & 13,2 \\
\hline $2 \vdash 3$ & - & - & 1 & 10,00 & 4 & 6,45 & 3 & 14,29 & 5 & 13,89 & - & - & 13 & 3,2 \\
\hline $3 \vdash 4$ & 1 & 0,36 & - & - & 3 & 4,84 & - & - & 2 & 5,56 & - & - & 6 & 1,4 \\
\hline $4 \vdash 5$ & - & - & - & - & 1 & 1,61 & - & - & 1 & 2,78 & - & - & 2 & 0,5 \\
\hline $5 \vdash 6$ & 1 & 0,36 & - & - & - & - & - & - & 2 & 5,56 & - & - & 3 & 0,7 \\
\hline Sem inf. & 4 & 1,45 & 1 & 10,00 & - & - & - & - & 1 & 2,78 & 1 & 16,67 & 7 & 1,7 \\
\hline Total & 275 & 100,0 & 10 & 100,0 & 62 & 100,0 & 21 & 100,0 & 36 & 100,0 & 6 & 100,0 & 410 & 100,0 \\
\hline $\begin{array}{l}\mathrm{X}^{2}=167,88 \\
\text { SMP }=\text { Sed } \\
\text { AdsMP }=A \\
\text { SM }=\text { Sede } \\
\text { AdsM }=\text { Ads } \\
\text { Outros }=\mathrm{Mu} \\
\mathrm{Si}=\text { Sem inf }\end{array}$ & $\begin{array}{l}\mathrm{p}= \\
\text { de mó } \\
\text { lscritos } \\
\text { e mód } \\
\text { critos } \\
\text { nicípio } \\
\text { ormaça }\end{array}$ & $\begin{array}{l}\text { dulo ass } \\
\text { ao mun } \\
\text { lo assis } \\
\text { municí } \\
\text { de out }\end{array}$ & as re & ide de & mód & alo assis & ste & ial e $\mathrm{F}$ & & & & & & \\
\hline
\end{tabular}

O menor tempo para chegada ao serviço da UNESP foi para quase a totalidade dos residentes em Botucatu. Quanto aos demais municípios, dadas as distâncias entre eles e a UNESP, era mesmo esperado um tempo maior. Municípios como Barão de Antonina, Itaporanga e Coronel Macedo, apresentam maiores dificuldades para encaminhamentos à UNESP devido a suas distâncias e buscam sua primeira referência que é Avaré. Outros, mais próximos, segundo informações dos gestores, embora tenham Avaré como primeira referência, acabam enviando pacientes diretamente para a UNESP, mesmo porque sofrem uma pressão maior dos usuários, que preferem a UNESP.

Independentemente da procedência, destaca-se que a grande maioria dos entrevistados veio de municípios que ficavam a menos de uma hora de Botucatu, reforçando, novamente, o caráter regional da UNESP. 


\subsection{Informações do Atendimento Médico}

Dos 410 pacientes entrevistados, obteve-se informações médicas de 390, mediante questionários aplicados aos médicos do $\mathrm{PA}$ e SE; 12 questionários não foram respondidos e 8 entrevistados não aguardaram a consulta médica. No PA todos os médicos são contratados para essa atividade de atendimento pela instituição. No $\mathrm{SE}$, além dos médicos contratados, atuam docentes da Faculdade de Medicina, em esquema de plantão, supervisionando o atendimento realizado por internos do $6^{\circ}$ ano do curso de graduação em medicina e por médicos residentes dos diversos departamentos e especialidades.

$\mathrm{Na}$ tabela 15 são apresentados os tipos de atendimentos realizados, segundo informações dos médicos que atenderam os pacientes no PA e SE.

Tabela 15 - Distribuição de freqüências absolutas e relativas nos questionários respondidos por médicos do Serviço de Urgência/Emergência do HC FMB que atenderam os pacientes entrevistados, segundo o tipo de atendimento realizado e local, Botucatu, março de 2002

\begin{tabular}{|c|c|c|c|c|c|c|}
\hline \multirow{3}{*}{ Tipo de atendimento } & \multicolumn{6}{|c|}{ Local } \\
\hline & \multicolumn{2}{|c|}{$\mathbf{P A}$} & \multicolumn{2}{|c|}{ SE } & \multicolumn{2}{|c|}{ Total } \\
\hline & $\mathbf{N}$ & $\%$ & $\mathbf{N}$ & $\%$ & $\mathbf{N}$ & $\%$ \\
\hline Urgência/emergência - nível terciário & 12 & 8,0 & 16 & 6,2 & 28 & 6,8 \\
\hline Urgência/emergência -nível secundário & 26 & 17,3 & 77 & 29,6 & 103 & 25,1 \\
\hline Sem urgência, Acomp.possível em hosp. secundário & 23 & 15,3 & 30 & 11,5 & 53 & 13,0 \\
\hline Sem urgência, Acomp. possível em UBS & $75^{*}$ & 50,0 & $91^{*}$ & 35,0 & 166 & 40,5 \\
\hline Sem informação & 4 & 2,7 & 36 & 13,8 & 40 & 9,6 \\
\hline Não preenchido & 4 & 2,7 & 8 & 3,1 & 12 & 2,9 \\
\hline Não aguardou consulta & 6 & 4,0 & 2 & 0,8 & 8 & 2,0 \\
\hline Total & 150 & 100,0 & 260 & 100,0 & 410 & 100,0 \\
\hline
\end{tabular}

Verifica-se que tanto no PA quanto no SE, os maiores percentuais foram de atendimentos sem necessidade de urgência com acompanhamento possível em UBS e o total de pacientes de todas as procedências que apresentou problemas que justificaram atendimento de Urgência/Emergência de nível terciário, na opinião dos médicos que os atenderam, foi de 28 pacientes $(6,8 \%)$.

$\mathrm{Na}$ próxima tabela são apresentados os tipos de atendimento, segundo a procedência dos doentes. 
Tabela 16 - Distribuição de freqüências absolutas e relativas nos questionários respondidos por médicos do Serviço de Urgência/Emergência do HC - FMB - PA e SE, que atenderam os pacientes entrevistados, segundo o tipo de atendimento realizado e município de procedência, classificado de acordo com o Plano Diretor de Regionalização, Botucatu, março de 2002

\begin{tabular}{|c|c|c|c|c|c|c|c|c|c|c|c|c|c|c|}
\hline \multirow[t]{2}{*}{ Tipo de atendimento } & \multicolumn{2}{|c|}{ SMP } & \multicolumn{2}{|c|}{ AdsMP } & \multicolumn{2}{|c|}{ SM } & \multicolumn{2}{|c|}{ AdsM } & \multicolumn{2}{|c|}{ Outros } & Procedência & SI & To & tal \\
\hline & $\mathbf{N}$ & $\%$ & $\mathbf{N}$ & $\%$ & $\mathbf{N}$ & $\%$ & $\mathbf{N}$ & $\%$ & $\mathbf{N}$ & $\%$ & $\mathbf{N}$ & $\%$ & $\mathbf{N}$ & $\%$ \\
\hline Urgência/Emergência - nível terciário & 12 & 4,36 & - & - & 7 & 11,29 & 3 & 14,29 & 4 & 11,11 & 2 & 33,33 & 28 & 6,8 \\
\hline Urgência/Emergência -nível secundário & 71 & 25,82 & 6 & 60,00 & 13 & 20,97 & 2 & 9,52 & 10 & 27,78 & 1 & 16,67 & 103 & 25,1 \\
\hline Sem urgência, Acompanhamento possível em hospital secundário & 33 & 12,00 & - & - & 8 & 12,90 & 2 & 9,52 & 10 & 27,78 & - & - & 53 & 13,0 \\
\hline Sem urgência, Acompanhamento possível em UBS & $114^{*}$ & 41,45 & 1 & 10,00 & $30 *$ & 48,39 & $11^{*}$ & 52,38 & 8 & 22,22 & 2 & 33,33 & 166 & 40,5 \\
\hline Sem informação & 32 & 11,64 & 3 & 30,00 & 2 & 3,23 & 1 & 4,76 & 1 & 2,78 & 1 & 16,67 & 40 & 9,6 \\
\hline Não preenchidos & 7 & 2,55 & - & - & - & - & 2 & 9,52 & 3 & 8,33 & - & - & 12 & 2,9 \\
\hline Não aguardou consulta & 6 & 2,18 & - & - & 2 & 3,23 & - & - & - & - & - & - & 8 & 2,0 \\
\hline Total & 275 & 100,0 & 10 & 100,0 & 62 & 100,0 & 21 & 100,0 & 36 & 100,0 & 6 & 100,0 & 410 & 100,0 \\
\hline
\end{tabular}

$\mathrm{X}^{2}=58,77 \quad \mathrm{p}=0,001$

SMP $=$ Sede de módulo assistencial e Pólo.

AdsMP $=$ Adscritos ao município sede de módulo assistencial e Pólo.

$\mathrm{SM}=$ Sede de módulo assistencial

AdsM = Adscritos a municípios sede de módulo assistencial

Outros $=$ Municípios de outras regiões

$\mathrm{Si}=\mathrm{Sem}$ informação 
Observa-se elevado percentual de atendimentos sem necessidade de urgência e com acompanhamento possível em Unidade Básica de Saúde, especialmente para os procedentes dos municípios SMP e SM.

Segundo a informação médica, apenas 20 pacientes $(4,9 \%)$ compareceram por encaminhamento adequado. Em 17 casos, os encaminhamentos foram considerados inadequados: por estarem mal esclarecidos (11), devido a letra estar ilegivel (3), por não ter sido realizado prévio contato (3).

Os gestores apresentam seus argumentos quanto à demanda espontânea de pacientes ao Serviço de Urgência/Emergência da UNESP por problemas que poderiam ser resolvidos no próprio município, respondendo à questão:

Em estudo realizado no Pronto Socorro da UNESP, verificamos importante demanda espontânea de pacientes que poderia ter seu problema de saúde resolvido em uma Unidade Básica, ou Hospital Secundário. O que você tem a dizer sobre isto? Que implicações isto pode ter?

\section{Quadro Sintese das Idéias Centrais}

\begin{tabular}{|l|l|}
\hline A & O encaminhamento para a UNESP é o máximo para alguns pacientes. \\
\hline B & $\begin{array}{l}\text { A rede básica não funcionando, a população, espontaneamente, tem que dar } \\
\text { conta do seu problema de saúde. }\end{array}$ \\
\hline C & $\begin{array}{l}\text { É mais fácil para o médico encaminhar, do que mostrar para o paciente que } \\
\text { o caso dele pode ser tratado aqui. }\end{array}$ \\
\hline D & $\begin{array}{l}\text { O sistema de saúde precisa ter melhor gestão. Não dá mais para esperar e } \\
\text { continuar como está. }\end{array}$ \\
\hline E & Para casos mais simples, ir na UNESP é ruim sob todos os aspectos. \\
\hline F & A UNESP só deveria atender pacientes com encaminhamento. \\
\hline G & Os médicos não querem atender urgências. \\
\hline H & O Pronto Atendimento e a Triagem são duas aberrações. \\
\hline
\end{tabular}

A - O encaminhamento para a UNESP é o máximo para alguns pacientes (G1, G5, G6, G7, G10, G13, G14, G15, G16, G17).

Eu acho que primeiro a população apesar da gente ter avançado vários anos aí desde a época das unificações dos serviços de atendimentos de saúde, a questão das 
ações integradas, essas coisas todas, a população continua, em parte, com uma visão que o hospital é o centro do atendimento.

A gente também tem isso aqui no próprio hospital nosso. A gente passa 3 mil pessoas por mês em nosso P.S. Cada equipe de PSF, cada médico do PSF, realiza 16 consultas por período. Então, são 32 consultas por equipe, vezes 5, 160 consultas/dia no PSF. E mesmo assim, ficam 3 mil pessoas aqui no nosso P.S. E lá vai do mesmo jeito. Nós temos um ônibus que sai daqui todos os dias cedo, que vai para lá. Porque se tem primeiro a mistica de que em Rubião resolve-se tudo. Segundo, Rubião aceita tudo. Porque é aquela história, já existe uma coisa sobre isso: - Se morrer na Unesp tudo bem, se morrer aqui é erro de alguém. Pessoas vêm até os médicos aqui e falam: Ah, eu gostaria que o senhor me encaminhasse para a Unesp. - ele fala: Não, mas não tem necessidade, eu posso estar resolvendo seu problema aqui. - Ah, não doutor, não sei quê... - Não, senhora, eu não vou encaminhar. Então você vê também que isso é uma vontade do paciente. E tem pessoas que vão com condução própria e acabam indo e você não tem como segurar esse paciente.

A DIR nos diz o seguinte: nós não podemos obrigar o paciente a se tratar aqui, nesta cidade. Então, se ele escolher se tratar lá, nós temos que deixar ele ir. Ele já temo cartão dele de atendimento lá. Ele passa num bloco, marca uma especialidade. Ele fez cardiologia, por exemplo, mas agora quer ofialmo, eles acabam rodando a Unesp toda.

A gente faz campanhas e mais campanhas para os pacientes ficarem aqui, só que a vontade do paciente tem que ser respeitada, não posso obrigá-lo a ficar aqui, ele quer ir lá, ele vai lá.

O encaminhamento para a Unesp é o máximo para alguns pacientes. Às vezes a gente tem o profissional aqui, mas eles ouviram falar que na Unesp o tratamento é muito melhor, que o paciente não morre, porque ele soube da história que o paciente operou aqui com o profissional e morreu. Essas coisas. Então hoje a gente briga muito. Quando eu assumi, eu acho assim, o secretário se torna incompetente quando ele tem uma demanda muito grande para fora. Ainda é grande a minha demanda. Se você pegar hoje, ainda é grande, quando eu pego eu me assusto. Nós já diminuímos um pouco, não muito, mas nós já diminuímos um pouco e às vezes que eu vou para a 
Unesp, que eu encontro meu ônibus lá, eu quero morrer. Falo assim: - Meu Deus, um ônibus vindo para cá? É uma coisa ruim para mim. Principalmente quando está indo para um atendimento básico mesmo. Mas a gente tem aqui alguns serviços e os usuários nem sabem o que a gente tem aqui, porque a Unesp acaba fazendo. Tem pacientes que falam assim: Ah, porque eu fui na Unesp fazer um ultra-som e vai demorar tantos dias. - Mas, aqui tem ultra-som. -Ah, mas eu não sabia. Eles às vezes vão direto para lá sem saber o que tem aqui. A gente aqui procura orientar, mas tem um pessoal que é um nivel um pouco mais superior, ou mesmo. -Ah, eu não quero tratar com tal médico, o doutor não sei o que... nós vamos lá na Unesp. A Unesp resolve tudo, a Unesp faz tudo. Eu acho que tem que ter um entrosamento das duas cidades, tanto da Unesp quanto das outras cidades, para ter mais orientação.

\section{B - A rede básica não funcionando, a população, espontaneamente, tem que dar conta do seu problema de saúde (G1, G2, G3, G4, G5, G7, G8, G9, G16).}

Outra questão é que, por exemplo, a questão nossa especifica é que a rede de atendimento básico daqui não funciona e, uma vez não funcionando, a população por sua vez tem que dar conta, ela espontaneamente tem que dar conta de como resolver o seu problema de saúde. Quer dizer, como resolver o problema de saúde se a rede básica não funciona? Só vai existir duas alternativas: ou vai no Pronto Socorro Municipal, que também tem suas falhas, ou no Pronto Socorro da. Unesp. Então, acaba indo para o Pronto Socorro da Unesp. Muita coisa poderia ser resolvida na atenção básica, mas essa pessoa, ou porque uma vez já não deu certo, ou porque ela procurou o serviço e realmente não conseguiu, ela acaba indo para lá espontaneamente. Acho que isso acontece com vários municipios, as pessoas vão de livre e espontânea vontade até o Pronto Socorro.

Eu vou falar o que eu já disse: que a rede básica daqui oferece um numero limitado de consultas, que é um sistema de saúde que tem um corte, não tem acesso a exames de laboratório. E os serviços que agendam consultas têm um tempo de agendamento longo. Você vai querer consultar hoje, não tem e tem que voltar daqui a um mês, daqui 15 dias, então o que a população faz? Ela procura porta aberta. Eu imagino 
que, hoje, quem está fazendo a maior parte da rede básica, que poderia ser feila na rede básica daqui, é a Faculdade de Medicina.

As unidades básicas trabalham num conceito dela de como ela deve trabalhar. Acho que os postos de saude precisam trabalhar de acordo com a necessidade da população em torno deles. Os horários de funcionamento têm que ser horários de funcionamento que interessem a população em torno deles. Então eu acho que o entendimento, na minha opinião é o seguinte: se não tivermos unidades, eu não vou chamar básica de saúde mais, porque básica parece uma coisa assim trivial, basiquinha, não é? Eu chamo de unidades essenciais de saúde. Se a gente não tiver unidades essenciais de saúde, que não é hospital, hospital não é uma unidade essencial de saúde, ele é um apêndice. Então, enquanto não tivermos unidades essenciais de saúde trabalhando em prol da comunidade que as cerca, nós não vamos nunca sair dessa coisa de sempre, uma super lotação em qualquer pronto socorro.

Uma parte vai porque diz que demora muito para esperar uma consulta, nem sempre é porque o médico não chegou, o médico chegou, só que ele vai primeiro atender os agendados e depois vai atender os extras, então a pessoa fica lá, a não ser que seja urgência, que é passado na frente. Mas se a pessoa não está urgente, está ali com um problema que não é tão grave e tal, ela é atendida no final.

Então eu acho assim, às vezes, não só esse motivo, pode até ser que, às vezes acabam escapando pacientes daqui porque o plantonista que está aqui no dia está pedindo algum outro exame mais minucioso, que aqui não pode por algum motivo, ou por ser final de semana, à noite, enfim, algumas dificuldades.

Acredito também que é porque eles querem confirmar com outros médicos o diagnóstico. Então eles chegam aqui, tomam o remédio, não esperam o tempo certo para o medicamento começar a fazer efeito, acha que não está dando resultado $e$ procuram outro médico, por livre e espontânea vontade. Vão para outros municípios, eu acho que é falta de orientação da farmácia de informar o paciente. 
C - É mais fácil, para o médico, encaminhar, do que mostrar para o paciente que o caso dele pode ser tratado aqui (G1, G11).

$E$ É eu acho que outra questão é o próprio encaminhamento do pessoal das redes básicas. $\mathrm{Na}$ medida que não conseguem fazer os diagnósticos, acabam encaminhando para o nível terciário, sendo que você poderia muito bem usar outros tipos de ambulatórios. Ambulatório regional, ou o próprio hospital secundário para fazer o diagnóstico, não ir direto para o nivel terciário.

Nós temos médicos que encaminham até cachorro, se pedir para encaminhar. $\dot{E}$ muito mais fácil para o médico encaminhar o paciente do que argumentar e mostrar para aquele paciente que o caso dele pode ser tratado aqui. É uma barreira também, que já diminuiu bastante no aspecto da facilidade da carta. Tanto é, que hoje eu tenho uma funcionária que controla os blocos de cartas. Não para brigar com os médicos, que não vamos questionar a conduta médica, mas só o fato de ele saber que tem que mandar buscar a carta lá com a fulana de tal, em alguns casos ele já nem manda buscar.

D -O sistema de saúde precisa ter melhor gestão. Não dá mais para esperar c continuar como está (G1, G4, G15, G16).

O município está em caráter de emergência, o que não dá mais para esperar e continuar da forma que ele está. Ele está sendo pressionado por isso, já é uma determinação que não tem escape, não adianta ele discursar mais. Ou ele faz ou ele faz, que ele está prejudicando inclusive os municipios da região, não assumindo a gestão que lhe cabe por ser o maior municipio da sede por ter a infra-estrutura que o municipio tem, ele tem que assumir os serviços existentes, ou ele tem que comprar, ou ele tem que contratar, tem que fazer, alguma coisa ele tem que fazer e não continuar esperando que alguém faça por ele. Ele não tem o diagnóstico total do seu custo, ele só tem discurso. Então, toda a discussão que a gente vai ter com ele, cle pergunta quanto ele vai receber, agora o que ele dá de demanda para todas as áreas ele nunca perguntou, então ele não sabe quanto ele interna, ele não sabe quanto vai para o Pronto Socorro, que não deveria ir, ele não sabe quanto a Unesp atende o 
que não deveria atender, ele não sabe quem vai para a Unesp que deveria estar lá mesmo, ele não sabe quanto custam os seus exames, ele não sabe quanto custam suas especialidades, ele não sabe, ele não tem, simplesmente, um diagnóstico disso. As implicações disto são, em primeiro lugar, porque a pessoa ocupa um lugar lá na Unesp, que poderia estar sendo ocupado por pessoas que realmente precisam, e precisam de um serviço maior, realmente do terciário, ou do secundário. Implica que aqui a gente vê que não está resolvendo o problema desse paciente, o paciente tem que sair do municipio para ir em outro, por, realmente, uma coisa que é básica e que podia ser resolvida, e o que eu acho muito complicado, ele tem o direito de estar aqui, de ser resolvido aqui, então falta a confiança dele aqui, por quê? Para a Unesp, a implicação disto é o excesso de uma demanda desnecessária que muitas vezes a gente vê lá. E para nós tem o custo, porque eles acabam indo, depois não têm dinheiro para retornar, a gente tem que mandar buscar. Eles ficam ligando fora de horário, porque querem que vá buscar. E a gente não vai buscar porque os ônibus nossos têm horário para buscar. A gente vai buscar aqueles casos que não têm condições de serem transportados com ônibus, mas esses que vão como demanda espontânea, têm que voltar com o ônibus da prefeitura depois. E tem vários outros fatores que interferem. As vezes eles vêm com a receita e porque os médicos lá são preparados para atender doenças mais graves, quando vai alguém com uma doença mais simples, eles vão dar medicação mais pesada. Ai ele retorna e não tem condição de comprar a medicação e, desde que foi receitado lá, ele também acha que o médico daqui não pode trocar aquela medicação. Então acaba trazendo problemas para a gente mesmo.

Então, a implicação disto, primeiro, é o ônus para o paciente, perda de tempo, mas eu acho que tem outra questão, é o gasto de dinheiro público. Existe um investimento na rede básica, existe um investimento na rede do nível secundário e nível terciário, quer dizer, no fim você acaba gastando dinheiro de todos os níveis para resolver um problema que em tese você poderia ter resolvido no nivel primário. 
E - Para casos mais simples, ir na UNESP é ruim sob todos os aspectos (G4, G5, G8, G17).

A Unesp é pior para problemas comuns, para problemas simples. Por quê? Porque a Unesp não consegue fazer o acompanhamento do paciente pelo mesmo profissional, quer dizer, o vínculo com o profissional ou com a equipe não se dá, é dificil. Cada dia que a pessoa vai, é um que está lá. O Pronto Socorro não é o local ideal para ver os problemas como um todo, ele vai ver só aquele problema imediato. O profissional da Unesp raciocina de forma complexa, porque ele está preparado, quer dizer, ele está lá esperando casos complexos, às vezes casos simples, banais, ele exagera nos exames, exagera nos procedimentos, sempre pensa no pior. Quando o médico da rede está mais acostumado, já tem uma percepção de que aquele caso é um caso simples. Quer dizer, ir para a Unesp é ruim para os casos mais simples sob todos os aspectos.

A gente aqui procura estar orientando os pacientes para não procurarem a UNESP, ou se eles forem, que retornem com as cartas. Mas lá na Unesp, eles não têm uma concordância geral disso. Tem pacientes que chegam lá para fazer uma cirurgiazinha plástica na orelha. Dai ele já fala assim: Ah, tem uma pintinha ali. Ah, você faz a fichinha ali, vai na dermato. Então o próprio pessoal da Unesp acaba incentivando os pacientes a irem mais, a procurarem mais a Unesp, porque ela que tem tudo, tem livre acesso.

\section{F - A UNESP só deveria atender pacientes com encaminhamento (G5, G6, G11, G12).}

A Unesp aceita tudo. Por isso que eu volto a falar, a Unesp precisa achar uma forma, e eu quero ser parceiro nisso com ela, para impedir a ida dessas pessoas que poderiam estar sendo resolvidos os casos na nossa unidade básica de saúde no nosso próprio hospital. Eu não quero isso porque eu gasto muito dinheiro aqui nessa cidade para ofertar um atendimento mínimo. Nosso orçamento de 10 milhões de reais da prefeitura, 25\%, ou seja, 2 milhões de reais é gasto em saủde. Eu acho que da região são poucos os municipios que têm esse comprometimento do orçamento 
com a saúde. Então, eu sou a favor de que a Unesp impeça esses pacientes de estarem indo lá.

Acho que só poderia atender paciente com encaminhamento. Acho que deveria ter uma triagem lá dentro da Unesp, que o paciente que chegasse sem o encaminhamento do município, eles não atendessem, mandassem de volta.

Outro caso, eu tenho pacientes que estão lá na Unesp há 8 anos em tratamento. Quer dizer, são aqueles pacientes que quando precisaram do sistema, nós não tínhamos o sistema de saúde hoje implantado e eu não sei se a Unesp hoje tem condições de triar esses pacientes novamente, mas eu tenho certeza de que pelo menos $30 \%$ desses pacientes, que estão lá, podem ser retornados para o município. Isso vai desafogar a Unesp, pode até afogar um pouco o meu sistema, mas eu vou ter menos aborrecimento com transporte, que nós temos com o transporte diário.

Minha proposta seria de um tipo de atendimento clássico de centro de saúde e um tipo de atendimento que incorporaria o que muita gente chama de pronto atendimento, mas que não é o pronto atendimento, daquele que o médico nunca viu, não sabe quem é, não tem vínculo e ele vai resolver assim: do umbigo para cima, aspirina, do umbigo para baixo, Buscopam. Como tem, digamos assim, a preparação pela enfermagem, quando chegar no médico, se ele precisa do médico, o médico vai complementar esse atendimento, então ele vai atuar mesmo na equipe. $E$ ai ele abre a porta da unidade, ai a população vai ter que ter, a partir do momento que a gente implantar isso na nossa rede, a população vai ter que ter a porta fechada no Pronto Socorro. Eu já autorizei os médicos (do SE e PA) a, desde que eles examinem rigorosamente os pacientes, que eles vêem que não é um caso de urgência, que é um caso comum, que esse médico possa dizer: Olha, não vou medicar nada, vai voltar para o Centro de Saúde.

\section{G - Os médicos não querem atender urgências (G5).}

Os médicos resistem muito a isso. Falam: Ah, eu não sou pago para atender urgências. - Mas não é urgência. Esse atendimento é atendimento necessário, mas não é uma coisa que precisa ser atendida naquele dia, digamos que seja uma urgência, o médico é contratado no centro de saúde para atender urgência sim, 
porque o que ele não é contratado é para atender emergência, que ai seria no Pronto Socorro. A outra resistência é que muitos médicos dizem que isso ai vai diminuir a qualidade do atendimento, porque você vai ficar atendendo um monte de gente e a qualidade do atendimento? E eu pergunto: está bom, então como é a qualidade do atendimento hoje que é assim: olha, acabou a ficha, vai para o Pronto Socorro. No Pronto Socorro ele vai ter um atendimento pior, no mesmo tempo, em 5 minutos.

\section{H - O Pronto Atendimento e a Triagem são duas aberrações (G3).}

No Pronto Socorro e Triagem temos duas grandes aberrações na minha opinião: um é o Pronto Atendimento, quando você não tem nada para fazer e não quer fazer nada, faça um pronto atendimento, porque ele não serve para nada. O Pronto Atendimento serve para dizer para o doente que não é aqui que você precisa vir. Se fosse bem feito o doente nem viria. Por que ele vai perder seu tempo, abre uma ficha, fica na sala de espera e um médico que é um material humano muito caro, diz para ele: mas não é aqui que o senhor devia ter vindo. E é isso que se faz no Pronto Atendimento. O paciente, obviamente, ele vai ao PA porque tem a impressão de que vai ser atendido. Então o Pronto Atendimento é um filtro para o Pronto Socorro. $\mathrm{Na}$ verdade, é preciso priorizar o Pronto Socorro, é preciso tirar $70 \%$ até $80 \%$ do atendimento de dentro do P.S e dizer para o paciente que ele não pode entrar. Outra aberração é a Triagem.

De acordo com os discursos dos gestores, os seguintes fatores explicam a procura do Serviço de Urgência/Emergência da UNESP:

- Confiança que depositam na UNESP;

- Deficiências da rede básica;

- Desconhecimento dos usuários sobre o potencial dos serviços oferecidos nas Unidades Básicas;

- O fato da UNESP manter suas portas abertas para o atendimento de pessoas cujos problemas de saúde poderiam ser resolvidos nas UBSs ou outros serviços de menor complexidade. 
Quanto à confiança dos usuários na UNESP e as deficiências da rede básica, estes aspectos jả foram objeto de análise neste estudo.

Sobre o desconhecimento dos usuários quanto aos serviços oferecidos nas UBSs, convém destacar que a divulgação de informações quanto ao potencial dos serviços de saúde e a sua utilização pelo usuário constitui um dos princípios estabelecidos na Lei Orgânica da Saúde, artigo $7^{\mathcal{Q}}$ (BRASIL 1991).

Encontra-se no relatório da $X$ Conferência Nacional de Saúde a recomendação para que os gestores do SUS, em todos os níveis, tornem públicas as informações sobre o atendimento em cada uma das unidades prestadoras de serviços do SUS, mediante:

- fixação, em todas as unidades e serviços de saúde do SUS, em local visivel e de fácil acesso aos usuários, de informações sobre as ações que oferece, horários de funcionamento, quadro de trabalhadores e seus horários e funções;

- publicações, contendo informações sobre capacidade instalada e as formas de acesso aos serviços da rede própria, conveniada e contratada;

- fixação, em todas as unidades públicas, conveniadas ou contratadas do SUS, em local e com formato de destaque, a mensagem: "Este é um Serviço do Sistema Único de Saúde. O usuário não deve pagar qualquer serviço ou taxa para ser atendido" (BRASIL 1998).

Apesar do estabelecido em lei e das recomendações das Conferências Nacionais, os serviços, de modo geral, não as observam integralmente, continuam organizados de tal forma que as relações entre trabalhadores de saúde e usuários têm se dado com um certo distanciamento e, por vezes, o usuário é culpado pelo seu desconhecimento.

As ações comunicativas deveriam possibilitar a compreensão do conteúdo das mensagens e inclusive sua contestação, para que pudessem ser reformuladas em benefício dos usuários.

Quanto à UNESP manter suas portas abertas para todo tipo de atendimento, os gestores dividem-se em duas correntes de opiniões. Uma que entende que o usuário tem direito de escolha e deve ser atendido. Outra que se posiciona a favor de que a UNESP não atenda os usuários com problemas que possam ser resolvidos nas UBSs. Esta segunda opinião é temerária, pois poderá desencadear condutas que desrespeitam os direitos dos usuários e a ética médica. 
Como implicações dessa busca do Serviço de Urgência/Emergência, os gestores percebem que isto pode significar para o Serviço de Urgência/Emergência da UNESP sobrecarga e gastos indevidos, para as UBSs mais despesas, principalmente com medicamentos mais caros que são prescritos nos serviços de urgência, além de uma certa acomodação, e, para os usuários, despesas com transportes, perda de tempo e um atendimento dirigido apenas à queixa, sem acompanhamento e sem vínculos.

Quanto à conduta médica adotada em relação aos pacientes atendidos no Serviço de Urgência/Emergência, a tabela 17 mostra as respostas dadas pelos médicos que atenderam aos pacientes entrevistados no Pronto Atendimento. 
Tabela 17 - Distribuição de freqüências absolutas e relativas nos questionários respondidos por médicos do Serviço de Urgência/Emergência do HC - FMB que atenderam os pacientes entrevistados no PA, segundo a conduta médica adotada e município de procedência, classificado de acordo com o Plano Diretor de Regionalização, Botucatu, março de 2002

\begin{tabular}{|c|c|c|c|c|c|c|c|c|c|c|c|c|c|c|}
\hline \multirow{3}{*}{$\begin{array}{c}\text { Conduta médica } \\
\text { PA }\end{array}$} & \multicolumn{14}{|c|}{ Procedência } \\
\hline & \multicolumn{2}{|c|}{ SMP } & \multicolumn{2}{|c|}{ AdsMP } & \multicolumn{2}{|c|}{ SM } & \multicolumn{2}{|c|}{ AdsM } & \multicolumn{2}{|c|}{ Outros } & \multicolumn{2}{|c|}{ SI } & \multicolumn{2}{|c|}{ Total } \\
\hline & $\mathbf{N}$ & $\%$ & $\mathbf{N}$ & $\%$ & $\mathbf{N}$ & $\%$ & $\mathbf{N}$ & $\%$ & $\mathbf{N}$ & $\%$ & $\mathbf{N}$ & $\%$ & $\mathbf{N}$ & $\%$ \\
\hline Dispensado sem atendimento & 1 & 1,2 & - & - & - & - & - & - & - & - & - & - & 1 & 0,6 \\
\hline Dispensado após atendimento, sem encaminhamento & 26 & 30,2 & - & - & 7 & 25,9 & 3 & 23,1 & 1 & 5,0 & - & - & 37 & 24,6 \\
\hline Atendido e encaminhado para hospital da região & - & - & - & - & - & - & - & - & 3 & 15,0 & - & - & 3 & 2,0 \\
\hline Atendido e encaminhado para UBS & 12 & 13,9 & 1 & - & 5 & 18,5 & 3 & 23,1 & 3 & 15,0 & 1 & 50,0 & 24 & 16,0 \\
\hline Atendido e encaminhado para consulta especialista SE & 27 & 31,4 & - & 50,0 & 3 & 11,1 & 5 & 38,5 & 7 & 35,0 & 1 & 50,0 & 44 & 29,3 \\
\hline Atendido e encaminhado para consulta triagem & 11 & 12,8 & - & - & 9 & 33,3 & 1 & 7,7 & 4 & 20,0 & - & - & 25 & 16,6 \\
\hline Atendido e encaminhado para NGA & 2 & 2,3 & - & - & - & - & - & - & - & - & - & - & 2 & 1,3 \\
\hline Atendido e encaminhado para internação no SE & - & - & 1 & - & - & - & - & - & - & - & - & - & - & - \\
\hline Atendido e encaminhado para internação no $\mathrm{HC}$ & - & - & - & 50,0 & - & - & - & - & - & - & - & - & 1 & 0,6 \\
\hline Atendido e agendado retorno no Setor de Emergência & - & - & - & - & - & - & - & - & - & - & - & - & - & - \\
\hline Atendido e agendado retorno no Pronto Atendimento & - & - & - & - & 1 & 3,7 & - & - & - & - & - & - & 1 & 0,6 \\
\hline Atendido, medicado, mas não aguardou conduta final & 1 & 1,2 & - & - & - & - & - & - & - & - & - & - & 1 & 0,6 \\
\hline Sem informação e não preenchidos & 2 & 2,3 & - & - & - & - & 1 & 7,7 & 2 & 10,0 & - & - & 5 & 3,3 \\
\hline Não aguardou consulta & 4 & 4,6 & & - & 2 & 7,4 & - & - & - & - & - & - & 6 & 4,0 \\
\hline Total & 86 & 100,0 & 2 & 100,0 & 27 & 100,0 & 13 & 100,0 & 20 & 100,0 & 2 & 100,0 & 150 & 100,0 \\
\hline
\end{tabular}

Sem análise estatística 
$\mathrm{Na}$ coluna dos totais verifica-se que a conduta mais freqüente $44(29,3 \%)$ foi a de encaminhamentos que o PA fez para consultas com especialistas do SE. Neste estudo já foram mencionados depoimentos de gestores que apontaram a busca do SE, pelos usuários, como uma via para se chegar mais rapidamente ao especialista, isto coincide com os dados desta tabela. Se a este total de encaminhamentos ao especialista do SE for acrescido o dos atendidos e encaminhados para consultas médicas na Triagem de Especialidades 25 (16,6\%), tem-se que $46 \%$ dos pacientes deste estudo, que procuraram o PA, receberam encaminhamento para consulta com especialistas.

Mediante os dados desta tabela, observa-se que o PA parece funcionar apenas como um local de triagem de pacientes para algumas unidades do HC - FMB ou para serviços de saúde da região de procedência dos usuários, ou seja, parece haver uma inversão na hierarquia dos atendimentos segundo os níveis de complexidade, constituindo-se o PA do serviço terciário em porta de entrada do sistema.

Quanto ao total de 37 pacientes $(24,6 \%)$ que foram atendidos e dispensados sem encaminhamentos, pode-se inferir que os problemas apresentados por estes usuários foram considerados, pelos médicos que os atenderam, como tendo sido solucionados ali mesmo no PA. Mesmo neste caso, seria recomendável que houvesse um encaminhamento ao serviço de saúde do município onde residem visando à continuidade da observação e ao acompanhamento.

A próxima tabela mostra as condutas médicas em relação aos atendimentos no Setor de Emergência. 
Tabela 18 - Distribuição de freqüências absolutas e relativas nos questionários respondidos por médicos do Serviço de Urgência/Emergência do HC -FMB que atenderam os pacientes entrevistados no SE, segundo a conduta médica adotada e município de procedência, classificado de acordo com o Plano Diretor de Regionalização, Botucatu, março de 2002

\begin{tabular}{|c|c|c|c|c|c|c|c|c|c|c|c|c|c|c|}
\hline \multirow{3}{*}{$\begin{array}{l}\text { Conduta médica } \\
\text { SE }\end{array}$} & \multicolumn{14}{|c|}{ Procedência } \\
\hline & \multicolumn{2}{|c|}{ SMP } & \multicolumn{2}{|c|}{ AdsMP } & \multicolumn{2}{|c|}{ SM } & \multicolumn{2}{|c|}{ AdsM } & \multicolumn{2}{|c|}{ Outros } & \multicolumn{2}{|c|}{ SI } & \multicolumn{2}{|c|}{ Total } \\
\hline & $\mathbf{N}$ & $\%$ & $\mathbf{N}$ & $\%$ & $\mathbf{N}$ & $\%$ & $\mathbf{N}$ & $\%$ & $\mathbf{N}$ & $\%$ & $\mathbf{N}$ & $\%$ & $\mathbf{N}$ & $\%$ \\
\hline Dispensado sem atendimento & - & - & - & - & - & - & 1 & 100,0 & - & - & - & - & 1 & 0,4 \\
\hline Dispensado após atendimento, sem encaminhamento & 99 & 52,4 & 1 & 12,5 & 14 & 40,0 & 3 & 37,5 & 5 & 31,2 & 1 & 25,0 & 123 & 47,3 \\
\hline Atendido e encaminhado para hospital da região & 1 & 0,5 & 2 & 25,0 & - & - & - & - & - & - & - & - & 3 & 1,2 \\
\hline Atendido e encaminhado para UBS & 21 & 11,1 & - & - & 6 & 17,1 & 1 & 12,5 & 1 & 6,2 & - & - & 29 & 11,2 \\
\hline Atendido e encaminhado para consulta especialista SE & 29 & 15,4 & 2 & 25,0 & 5 & 14,3 & - & - & 5 & 31,2 & 1 & 25,0 & 42 & 16,1 \\
\hline Atendido e encaminhado para consulta triagem & 13 & 6,9 & 1 & 12,5 & 3 & 8,7 & 2 & 25,0 & 2 & 12,5 & 1 & 25,0 & 22 & 8,5 \\
\hline Atendido e encaminhado para NGA & 2 & 1,1 & - & - & - & - & - & - & - & - & - & - & 2 & 0,8 \\
\hline Atendido e encaminhado para internação no SE & 4 & 2,1 & 1 & 12,5 & 2 & 5,7 & - & - & - & - & - & - & 7 & 2,7 \\
\hline Atendido e encaminhado para internação no HC & - & - & - & - & 3 & 8,6 & - & - & - & - & 1 & 25,0 & 4 & 1,5 \\
\hline Atendido e agendado retorno no Setor de Emergência & 3 & 1,6 & - & - & 1 & 2,9 & - & - & 1 & 6,2 & - & - & 5 & 1,9 \\
\hline Atendido e agendado retorno no Pronto Atendimento & - & - & - & - & - & - & - & - & - & - & - & - & - & - \\
\hline Atendido, medicado, mas não aguardou conduta final & 1 & 0,5 & - & - & - & - & - & - & - & - & - & - & 1 & 0,4 \\
\hline Sem informação e não preenchidos & 14 & 7,4 & 1 & 12,5 & 1 & 2,9 & 1 & 12,5 & 2 & 12,5 & - & - & 19 & 7,3 \\
\hline Não aguardou consulta & 2 & & - & - & - & - & - & - & - & - & - & - & 2 & 0,8 \\
\hline Total & 189 & 100,0 & 8 & 100,0 & 35 & 100,0 & 8 & 100,0 & 16 & 100,0 & 4 & 100,0 & 260 & 100.0 \\
\hline
\end{tabular}

Sem análise estatística 
Neste estudo, por um lapso, não foi registrado o horário de chegada do paciente. Entretanto, foi possível identificar, mediante observação e depoimentos dos médicos e enfermeiros que trabalham no $\mathrm{SE}$, que há uma demanda maior de pacientes no SE após as 19 horas, quando o PA encerra suas atividades e todos passam a ser atendidos no SE. Lembrando, também, que após esse horário, a maioria das UBSs não se encontra aberta. Esse movimento é mais intenso até as 24 horas e entre 24 e 7 horas cai sensivelmente, porém, em geral, a demanda desse periodo é de pessoas apresentando problemas mais graves ou sintomas mais severos de dor e desconforto.

No SE também é verificado o encaminhamento para consultas com especialista, 41 (15,8\%). Neste caso, deduz-se que o atendimento de emergência está implicando uma interconsulta com especialista. Mas também observa-se que 22 $(8,5 \%)$ pacientes foram encaminhados para a Triagem de Especialidades. Certamente uma parcela destes pacientes poderia ter sido atendida nos serviços de saúde do município onde reside e ter agendadas consultas na Triagem de Especialidades, em conformidade com as normas existentes, caso houvesse maiores facilidades para isto. Ou, o que seria mais adequado, se os serviços pudessem fazer essa triagem, encaminhando os usuários diretamente aos ambulatórios de especialidades. Poderia, deste modo, aliviar a sobrecarga do PA, SE e Triagem da UNESP e evitar idas e vindas inúteis para os doentes.

Chama atenção o baixíssimo número de encaminhamentos (2) para o Núcleo de Gestão Assistencial (NGA) da região e localizado em Botucatu. Ao que parece, há um desconhecimento da existência desse serviço por parte dos profissionais da UNESP, ou falta de credibilidade, o que pode também ser revelador da tímida ou ineficaz presença do NGA na cidade e na região.

$\mathrm{O}$ total de pacientes atendidos no SE e dispensados sem encaminhamentos $123(47,3 \%)$, maior do que o encontrado no PA, sugere que o SE, mais do que o PA, tem um compromisso quase que exclusivo com o atendimento imediato do doente.

Quanto aos diagnósticos, foi verificado no PA que o primeiro diagnóstico citado por maior número de entrevistados $53(35,3 \%)$, segundo classificação por Capítulo da CID 10, foi referente ao Capítulo XVIII - Sintomas, sinais e achados 
anormais de exames clínicos e de laboratório. Em segundo lugar, 28 (18,6\%) pacientes citaram doenças do Capítulo XIII - Doença do sistema osteomuscular e do trato conjuntivo.

No SE, $81(31,25 \%)$ citaram doenças do Capitulo XVIII - Sintomas, sinais e achados anormais de exames clínicos e de laboratório. Em segundo lugar 54 (20,7\%) citaram doenças do Capítulo XIX - Lesões e envenenamentos e algumas outras conseqüências de causas externas.

As maiores frequiências, tanto no $\mathrm{PA}$, quanto no $\mathrm{SE}$, de doenças classificadas no Capítulo XVIII podem ser explicadas pelo fato das respostas dos pacientes à pergunta - qual é a doença que o acomete e que motivou sua vinda a este serviço estarem relacionadas à descrição de queixas, sinais e sintomas e não ao nome da doença.

Os diagnósticos feitos pelos médicos do PA, em ordem decrescente das freqüências, para os cinco mais registrados foram:

$1^{\circ}$ - Capítulo XIII - Doenças do sistema osteomuscular - $25(16,6 \%)$.

$2^{\circ}$ - Capítulo XVIII - Sintomas, sinais e achados de exames clínicos e de laboratórios - $16(10,6 \%)$.

$3^{\circ}$ - Capítulo XIV - Doenças do aparelho geniturinário - $12(8 \%)$.

$4^{\circ}$ - Capítulo XI - Doenças do aparelho digestivo - $11(7,3 \%)$.

$5^{\circ}$ - Capítulo VII - Doenças do olho e anexos - 10 (6,6\%).

Capítulo XII - Doenças da pele e do tecido subcutâneo $10(6,6 \%)$.

No SE os diagnósticos mais registrados foram:

$1^{\circ}$ - Capítulo X - Doenças do aparelho respiratório - 50 (19,2\%).

$2^{\circ}$ - Capítulo XIX - Lesões e envenenamentos e algumas outras conseqüências de causas externas $49(18,8 \%)$.

$3^{\circ}$ - Capítulo XVIII - Sintomas, sinais e achados de exames clínicos e de laboratórios - $28(10,7 \%)$.

$4^{\circ}$ - Capítulo XI - Doenças do aparelho digestivo $25(9,6 \%)$.

$5^{\circ}$-Capítulo XIV - Doenças do aparelho geniturinário - 17 (6,5\%).

A tabela seguinte apresenta informações referentes aos diagnósticos 
citados pelos pacientes entrevistados, segundo a procedência destes.

Tabela 19 - Distribuição de freqüências absolutas e relativas na amostra de pacientes entrevistados no Serviço de Urgência/Emergência do HC - FMB, segundo o primeiro diagnóstico (Capítulo - CID 10) referido pelos entrevistados e município de procedência, classificado de acordo com o Plano Diretor de Regionalização, Botucatu, março de 2002

\begin{tabular}{|c|c|c|c|c|c|c|c|c|c|c|c|c|c|c|}
\hline \multirow[t]{2}{*}{$\begin{array}{l}\text { Capítulo } \\
\text { CID 10** }\end{array}$} & \multicolumn{14}{|c|}{ Procedência } \\
\hline & $\mathbf{N}$ & $\%$ & $\mathbf{N}$ & $\%$ & $\mathbf{N}$ & $\%$ & $\mathbf{N}$ & $\%$ & $\mathbf{N}$ & $\%$ & $\mathbf{N}$ & $\%$ & $\mathbf{N}$ & $\%$ \\
\hline I & 3 & 1,1 & - & - & - & - & 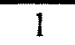 & 4,8 & 2 & 5,6 & & - & 6 & 1,5 \\
\hline II & 1 & 0,4 & 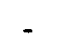 & - & - & - & 1 & 4,8 & I & 2,8 & & 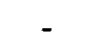 & & 0,7 \\
\hline II & 1 & 0,4 & - & - & - & - & - & - & - & - & & - & 1 & 2 \\
\hline II & 1 & 0,4 & - & - & - & - & - & . & - & - & - & - & 1 & 2 \\
\hline$v$ & ? & 0,7 & - & - & 1 & 1,6 & - & - & 1 & 2,8 & & - & 4 & 0 \\
\hline VI & 1 & 0,4 & - & - & 2 & $y$ & - & - & - & . & & - & 3 & 7 \\
\hline $\mathrm{V}$ & 11 & 4,0 & - & - & 6 & 9,7 & 1 & 4,8 & 4 & 11,1 & - & - & 22 & 4 \\
\hline VIII & 13 & 4,7 & - & - & - & - & - & - & 1 & 2,8 & - & - & 14 & 3,4 \\
\hline ? & 6 & 2,2 & - & - & 1 & 1,6 & 1 & 4,8 & 1 & 2 & . & - & 0 & 2 \\
\hline $\mathrm{x}$ & 24 & 8,7 & 1 & 10,0 & 3 & 4,8 & - & - & 2 & 5,6 & 1 & 16,7 & 31 & 6 \\
\hline$X$ & 12 & 4,4 & - & - & 5 & 8 & - & - & 3 & 8,3 & 1 & 16,7 & 1 & 5,1 \\
\hline $\mathrm{X}$ & 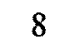 & 2,9 & - & - & 3 & 4,8 & 2 & 9,5 & - & . & - & - & 3 & 3,2 \\
\hline $\mathrm{x}$ & 34 & 12,4 & 1 & 0,0 & 6 & 9,7 & 1 & 4,8 & 3 & 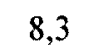 & & 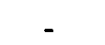 & 45 & 11,0 \\
\hline XIV & 15 & 5,4 & - & - & 5 & 8,1 & 1 & 4,8 & 2 & 5,6 & - & - & 23 & 5,6 \\
\hline & - & - & - & - & - & - & - & - & 1 & 2,8 & - & - & 1 & 0,2 \\
\hline & - & - & - & - & - & - & - & - & - & - & & - & - & - \\
\hline & - & - & 1 & 10,0 & . & - & - & - & 1 & 2,8 & & - & 2 & 0,5 \\
\hline XVIII & 87 & 31,6 & 2 & 20,0 & 24 & 38,7 & 9 & 42,8 & 9 & 25,0 & 3 & 50,0 & 134 & 32,7 \\
\hline & 47 & 17,1 & 5 & 50,0 & 4 & 6,4 & 2 & 9,5 & 5 & 13,9 & 1 & 16,7 & 64 & 15,6 \\
\hline$X 7$ & - & - & - & - & - & 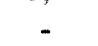 & 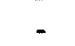 & - & - & - & - & - & - & - \\
\hline XXI & 9 & 3,3 & - & - & 2 & 3,2 & 2 & 9,5 & - & - & - & - & 13 & 3,2 \\
\hline Total & 275 & 100,0 & 10 & 100,0 & 62 & 100,0 & 21 & 100,0 & 36 & 100,0 & 6 & 100,0 & 410 & 100,0 \\
\hline $\begin{array}{l}\text { Doença do } \\
\text { circulatóri } \\
\text { pele e do } \\
\text { XIV=Doe } \\
\text { originadas } \\
\text { cromossôr }\end{array}$ & $s \mathrm{dc}$ & $\begin{array}{l}\text { anexos } \\
\text { Doença } \\
\text { subcu } \\
\text { aparell } \\
\text { eríodo }\end{array}$ & ge & $\begin{array}{l}\text { Doer } \\
\text { relho } \\
\text { XIII } \\
\text { turiná } \\
\text { al; X }\end{array}$ & $\begin{array}{l}\text { ça d } \\
\text { respi } \\
=\text { Doe } \\
\text { ino; }>\end{array}$ & $\begin{array}{l}\text { sortar } \\
\text { uvido } \\
\text { ório; } \\
\text { a do } \\
=\text { Gra } \\
\text { lalfor }\end{array}$ & $\begin{array}{l}\text { e d } \\
\mathbf{X I}= \\
\text { sist } \\
\text { avid }\end{array}$ & $\begin{array}{l}\text { pófise } \\
\text { ença a } \\
\text { a ost } \\
\text { parto }\end{array}$ & $\begin{array}{l}\text { mastó } \\
\text { o apa } \\
\text { comus } \\
\text { e pue } \\
\text { enitas }\end{array}$ & $\begin{array}{l}\text { Side; I } \\
\text { relho d } \\
\text { cular } \\
\text { rpério; }\end{array}$ & & Algu & is afe & $\begin{array}{l}\text { dos } \\
\text { ais e } \\
\text { VII = } \\
\text { relho } \\
\text { ca da } \\
\text { tivo; } \\
\text { ções } \\
\text { alias } \\
\text { órios }\end{array}$ \\
\hline
\end{tabular}

Destaca-se, nesta tabela, que os entrevistados procedentes do município SMP (Botucatu), dos municípios SM, dos adscritos aos SM e de outras regiões relataram, 
com maior freqüência, diagnósticos agrupados no Capítulo XVIII - Sintomas, sinais e achados anormais de exames clínicos e de laboratório.

Para os procedentes de municípios adscritos ao SMP, a maior freqüência foi para os diagnósticos do Capítulo XIX - Lesões e envenenamentos e conseqüências de causas externas. Porém, o pequeno número de pacientes entrevistados procedentes destes municípios dificulta análise da significância desse resultado.

A tabela 20 apresenta os registros dos diagnósticos feitos pelos médicos que atenderam aos pacientes entrevistados.

Tabela 20 - Distribuição de freqüências absolutas e relativas nos questionários respondidos por médicos do Serviço de Urgência/Emergência do HC FMB, segundo o primeiro diagnóstico (Capítulo - CID 10) feito pelo médico e município de procedência, classificado de acordo com o Plano Diretor de Regionalização, Botucatu, março de 2002

\begin{tabular}{|c|c|c|c|c|c|c|c|c|c|c|c|c|c|c|}
\hline \multirow{3}{*}{$\begin{array}{l}\text { Capítulo } \\
\text { CID } 10^{*}\end{array}$} & \multicolumn{14}{|c|}{ Procedência } \\
\hline & \multicolumn{2}{|c|}{ SMP } & \multicolumn{2}{|c|}{ AdsMP } & \multicolumn{2}{|c|}{ SM } & \multicolumn{2}{|c|}{ AdsM } & \multicolumn{2}{|c|}{ Outros } & \multicolumn{2}{|c|}{ SI } & \multicolumn{2}{|c|}{ Total } \\
\hline & $\mathbf{N}$ & $\%$ & $\mathbf{N}$ & $\%$ & $\mathbf{N}$ & $\%$ & $\mathbf{N}$ & $\%$ & $\mathbf{N}$ & $\%$ & $\mathbf{N}$ & $\%$ & $\mathbf{N}$ & $\%$ \\
\hline I & 11 & 4,0 & - & - & 1 & 1,6 & - & - & 3 & 20,0 & - & - & 15 & 3,7 \\
\hline II & 1 & 0,4 & - & - & 1 & 1,6 & 1 & 4,8 & - & - & - & - & 3 & 0,7 \\
\hline III & 2 & 0,7 & - & - & - & - & - & - & - & - & - & - & 2 & 0,5 \\
\hline IV & 2 & 0,7 & - & - & - & - & - & - & - & - & - & - & 2 & 0,5 \\
\hline $\mathrm{V}$ & 6 & 2,2 & - & - & 2 & 3,2 & 1 & 4,8 & 1 & 2,8 & - & - & 10 & 2,4 \\
\hline VI & 4 & 1,4 & - & - & 3 & 4,8 & - & - & - & - & 1 & 16,7 & 8 & 1,9 \\
\hline VII & 8 & 2,9 & - & - & 6 & 9,7 & 1 & 4,8 & 2 & 5,6 & - & - & 17 & 4,1 \\
\hline VIII & 10 & 3,6 & - & - & 4 & 6,4 & - & - & 1 & 2,8 & - & - & 15 & 3,7 \\
\hline IX & 11 & 4,0 & - & - & 4 & 6,4 & 1 & 4,8 & 3 & 8,3 & - & - & 19 & 4,6 \\
\hline$X$ & 44 & 16,0 & 2 & 20,0 & 8 & 12,9 & 1 & 4,8 & 3 & 8,3 & 1 & 16,7 & 59 & 14,4 \\
\hline XI & 23 & 8,4 & 1 & 10,0 & 4 & 6,4 & 2 & 9,5 & 6 & 16,7 & - & - & 36 & 8,8 \\
\hline XII & 12 & 4,4 & - & - & 2 & 3,2 & 3 & 14,3 & - & - & - & - & 17 & 4,1 \\
\hline XIII & 26 & 9,4 & 1 & 10,0 & 8 & 12,9 & 1 & 4,8 & 3 & 8,3 & - & - & 39 & 9,5 \\
\hline XIV & 16 & 5,8 & - & - & 6 & 9,7 & 2 & 9,5 & 4 & 11,1 & 1 & 16,7 & 29 & 7,1 \\
\hline XV & - & - & - & , & - & - & - & - & - & - & - & - & - & - \\
\hline XVI & - & - & - & - & - & - & - & - & - & - & - & - & - & - \\
\hline XVII & 1 & 0,4 & 1 & 10,0 & - & - & - & - & 1 & 2,8 & - & - & 3 & 0,7 \\
\hline XVIII & 36 & 13,1 & - & - & 4 & 6,4 & 2 & 9,5 & - & - & 2 & 33,3 & 44 & 10,7 \\
\hline XIX & 41 & 14,9 & 5 & 50,0 & 5 & 8,1 & 2 & 9,5 & 5 & 13,9 & 1 & 16,7 & 59 & 14,4 \\
\hline$X X$ & - & - & - & - & - & - & - & - & - & - & - & - & - & - \\
\hline XXI & 8 & 2,9 & - & - & 2 & 3,2 & 2 & 9,5 & 1 & 2,8 & - & - & 13 & 3,2 \\
\hline Não preenchidos & 7 & 2,5 & - & - & - & - & 2 & 9,5 & 3 & 8,3 & - & - & 12 & 2,9 \\
\hline $\begin{array}{c}\text { Não aguardou } \\
\text { consulta }\end{array}$ & 6 & 2,2 & - & - & 2 & 3,2 & - & - & - & - & - & - & 8 & 1,9 \\
\hline Total & 275 & 100,0 & 10 & 100,0 & 62 & 100,0 & 21 & 100,0 & 36 & 100,0 & 6 & 100,0 & 410 & 100,0 \\
\hline
\end{tabular}


$\mathbf{I}=$ Algumas doenças infecciosas e parasitárias; $\mathbf{I}$ = Neoplasias; $\mathbf{I} \mathbf{I}=$ Doenças do sangue e dos órgãos hematopoiéticos e alguns transtornos imunitários; IV=Doenças endócrinas, nutricionais e metabólicas; $\mathbf{V}=$ Transtornos mentais e comportamentais; $\mathbf{V I}=$ Doença do sistema nervosos; VII= Doença do olho e anexos; VIII= Doença do ouvido e da apófise mastóide; IX = Doença do aparelho circulatório; $\mathbf{X}=$ Doença do aparelho respiratório; $\mathbf{X I}=$ Doença do aparelho digestivo; $\mathbf{X} \mathbf{I I}=$ Doença da pele e do tecido subcutâneo; XIII=Doença do sistema osteomuscular e do tecido conjuntivo; $\mathbf{X I V}=$ Doenças do aparelho geniturinário; $\mathbf{X V}=$ Gravidez, parto e puerpério; $\mathbf{X V I}=$ Algumas afecções originadas no periodo perinatal; $\mathbf{X V I I}=$ Malformações congênitas e deformidades e anomalias cromossômicas; $\mathrm{XVIII=} \mathrm{Sintomas,} \mathrm{sinais} \mathrm{e} \mathrm{achados} \mathrm{anormais} \mathrm{de} \mathrm{exames} \mathrm{clínicos} \mathrm{e} \mathrm{de} \mathrm{laboratórios}$ não classificados em outra parte; $\mathbf{X I X}=$ Lesões e envenenamentos e algumas outras conseqüências de causas externas; $\mathbf{X X}=$ Causas externas de morbidade e de mortalidade; $\mathbf{X X I}=$ Fatores que influenciam o estado de saúde e o contato com os serviços de saúde.

Nesta tabela observa-se que os diagnósticos médicos mais freqüentes, para os procedentes do município SMP (Botucatu), foram os agrupados no Capítulo X Doenças do Aparelho Respiratório. Para os procedentes dos municípios adscritos ao SMP houve coincidência quanto à freqüência dos diagnósticos médicos com os referidos pelos pacientes entrevistados, nos agrupamentos do Capítulo XIX - Lesões e envenenamentos e outras conseqüências de causas externas. Apesar do pequeno número, pode-se inferir que a facilidade para identificação deste tipo de morbidade propicia essa coincidência.

O número total dos diagnósticos do Capítulo XVIII, que se referem a sinais e sintomas sem classificação, mencionados pelos pacientes, foi 134. Já, os informados pelos médicos que os atenderam, esse total foi de 44 , significando que $35 \%$ dos pacientes que apresentaram queixas, sem identificação do diagnóstico, receberam definição diagnóstica nesse atendimento médico.

A seguir, será apresentado o discurso do coletivo dos pacientes entrevistados ao responderem à pergunta:

\title{
O que o senhor(a) veio fazer neste serviço hoje?
}

\author{
Quadro Síntese das Idéias Centrais
}

\begin{tabular}{|l|l|}
\hline A & Trazer pessoa da família para passar por consulta médica. \\
\hline B & Vim ser atendido pelo médico porque eu estou passando mal. \\
\hline C & Vim fazer drenagem, exames, passar por consulta. \\
\hline
\end{tabular}


A - Trazer pessoa da família para passar por consulta médica (P1, P5, P6, P13, P14, P17, P19, P25, P29).

Vim passar por consulta pessoa da minha familia, porque não tem outro lugar a não ser aqui.

B - Vim ser atendido pelo médico porque eu estou passando mal (P2, P3, P8, P9, P10, P11, P12, P15, P16, P18, P20, P21, P22, P26, P23, P24, P28, P30).

Hoje eu vim ser atendido pelo médico mesmo, porque eu estou passando mal com esse sintoma que apareceu. Eu vim tentar resolver esse problema que eu estou tendo. Para saber o que realmente eu tenho. Vim propriamente pedir socorro para esse problema. Porque eu me encontro um pouco enferma, e estou querendo sarar, estou precisando sarar com urgência, porque eu preciso trabalhar.

\section{C - Vim fazer drenagem, exames, passar por consulta (P4, P7, P27).}

Vim para poder fazer a drenagem, fazer uns exames, passar por uma consulta. Porque tem uma cirurgia e realmente tem mesmo uma cirurgia para fazer e eu acho que aqui é o lugar que a gente mais usa e tem recurso.

Nos discursos referentes à idéia central "vim ser atendido pelo médico porque eu estou passando mal", foram suprimidos os diagnósticos, sintomas e danos sofridos mencionados pelos entrevistados, porque já constaram das informações obtidas nas entrevistas estruturadas e por serem redundantes.

Embora uma parcela significativa dos entrevistados não tenha necessitado de atendimento médico de urgência, segundo as informações dadas pelos médicos em suas respostas ao questionário aplicado, foi possível perceber que os entrevistados, ao falarem sobre seus problemas de saúde, enfatizam a necessidade de atendimento em caráter de urgência. Essa estratégia pode ser entendida mediante análise do modo como a doença é experimentada pelo doente, do mal estar que ela produz e dos comportamentos sócio-culturais ligados às doenças (GOMES et al. 2002). 
Não foi objetivo deste estudo conhecer significados atribuidos, pelos enfermos entrevistados, à situação de doença, mas identificar os tipos de busca de atendimento médico para resolução do problema de saúde.

Pelas dificuldades observadas quanto ao acesso dos usuários em todos os níveis de atenção à saúde e pela presença de um hospital universitário que mantém suas portas abertas para o atendimento caracterizado como Urgência/Emergência, é compreensível que os usuários adotem estratégias que garantam o atendimento. 
4.5 O atendimento aos preceitos do SUS na perspectiva dos gestores.

Os gestores falam sobre seus pontos de vista quanto à equidade, integralidade, qualidade e controle social da assistência à saúde prestada em seus municípios nos discursos referentes às seguintes questões:

Eu gostaria que você falasse um pouco sobre algumas características da assistência à saúde em seu município. Pode ser? Então, com relação à equidade da atenção, como está?

\section{Quadro Síntese das Idéias Centrais}

\begin{tabular}{|l|l|}
\hline A & Não existe equidade, o acesso é ruim e a oferta de serviços insuficiente. \\
\hline B & O município de Botucatu não respeita a hierarquia. \\
\hline C & A Faculdade de Medicina de Botucatu inibiu os serviços municipais. \\
\hline D & A eqüidade está sendo conseguida com a introdução do PSF. \\
\hline E & O atendimento é resolutivo e universal. \\
\hline
\end{tabular}

A - Não existe equidade, o acesso é ruim e a oferta de serviços insuficiente (G1, G2, G3, G5, G9, G10, G11, G13, G16, G17).

A gente entende que igualdade seria para todas as pessoas e a equidade nós teriamos que ter uma certa prioridade das pessoas que realmente necessitam do serviço e das que podem esperar um pouquinho mais. Nós temos uma assistente social que nos auxilia e quando uma pessoa vem procurar nossa ajuda e nós sabemos até que ela tem um pouquinho mais de condições, a gente procura levá-la a contribuir conosco, para que ceda a vez ou procure resolver o problema por ela mesma. Algumas exceções que se prendem que a saúde é um direito de todos $e$ exigem, a gente procura atender, porque a lei é clara, a saúde é um direito de todos. A eqüidade acaba não sendo respeitada, uma vez que os pacientes não têm o mesmo acesso aos serviços de saúde, quem tem mais condições de se locomover acaba sendo atendido. A rede básica de Botucatu não se importa com a eqüidade, quem conseguir acessar o serviço primeiro, consome o produto. Em algumas unidades acontece exatamente o contrário da eqüidade, pois as pessoas com uma condição sócio-econômica melhor, ou cultural ou educacional, são atendidas mais 
prontamente e com alguma educação extra do que aquelas com nivel sócioeconômico pior. Então, não existe eqüidade, o acesso é ruim e a oferta de serviços insuficiente.

Botucatu é uma cidade com 100.000 habitantes que tem uma oferta de serviços municipais de saúde muito aquém da necessidade da sua população, porém se os equipamentos estivessem integrados, a oferla de serviços seria mais abrangente, seria até possivel garantir equidade.

As pessoas quando são atendidas, até são bem atendidas, mas o problema é que as instituiç̧ões de saúde não dão conta da demanda e isso tem causado vários transtornos. A cobertura das unidades varia de unidade para unidade, mas mesmo a unidade que cobre mais a população, não consegue dar conta.

Nós ainda estamos abaixo do que foi pactuado, então ainda faltam profissionais.

$O$ dinheiro é pouco, mas qualquer bom administrador administra com pouco dinheiro, minha maior dificuldade é recursos humanos. Não tem como fazer um planejamento se não tiver recursos humanos. Hoje eu tenho recursos, mas tenho que capacitar os profissionais.

\section{B - O município de Botucatu não respeita a hierarquia (G3, G4, G5).}

De um lado, alguns municipios avançaram um pouco e conseguem fazer alguma coisa na gestão básica, porém, o município de Botucatu, pelo fato de não estar estruturado como ele precisa e ter uma porta aberta no serviço de referência (terciária) que é o HC da UNESP, ele ocupa todas as possibilidades dentro da regional de saúde, não respeitando a hierarquia. Essa porta é extremamente desigual em relação aos demais (municípios), então essa questão da eqüidade ainda é discurso.

A maior parte dos pacientes no Pronto Socorro da Unesp é de Botucatu, chega alguns meses a 70\%. O que é um pouco esperado, enquanto o Pronto Socorro da Unesp tiver as portas abertas para qualquer tipo de problema. Então o reflexo do não acolhimento da demanda pelos centros de saúde eu acho que leva a um acúmulo de pacientes procurando o Pronto Socorro. As pessoas substituem esse tipo de atendimento de centro de saúde pelo atendimento de pronto socorro. 


\section{C - A Faculdade de Medicina inibiu os serviços municipais (G3, G5).}

A Faculdade de Medicina desempenha papel acomodador: eu não preciso fazer, já que eu tenho aqui no municipio um hospital que se preocupa em fazer. Esse é um papel que a Faculdade de Medicina acabou fazendo com Botucatu em relação aos serviços municipais. Ela, de uma certa maneira, os inibiu. Agora está procurando estimular, mas fundamentalmente, no município, a oferta é insuficiente.

\section{D - A eqüidade está sendo conseguida com a introdução do PSF (G6, G11, G12).}

Hoje se vê o paciente como um todo, inserido numa familia, num meio, esse meio é valorizado. O médico e a enfermeira têm suas visitas domiciliares, principalmente para pacientes que não tenham condições de ir até o posto e isto é uma caracteristica da eqüidade, tratar de forma diferente os diferentes, ou seja, aqueles que não têm acesso aos serviços de saúde, têm a garantia de um acompanhamento mais de perto. Quando atendido por especialista, em agendamento pré-definido o paciente retorna ao médico da familia para continuidade do tratamento. Tinhamos anteriormente a unidade hospitalar que está desativada, hoje só tem a saúde da familia mesmo.

Hoje eu posso garantir que o nosso poder público, o nosso prefeito, está valorizando cada vez mais a saúde preventiva, que é investir no centro de saúde, investir na prevenção, do que há poucos anos atrás, que era investir no pronto socorro, investir no hospital. Antes se pensava em ampliar pronto socorro, ampliar hospital, hoje já tive que correr atrás de arrecadar recursos para implantar o PSF, que infelizmente não consegui ainda, porque isso ainda é um tabu a ser quebrado, pois para o municipio manter essa equipe (PSF), vai praticamente tirar da internação. Isso reverte imediatamente, só que o pessoal de planejamento que é o pessoal do juridico, ainda não tem essa visão. 


\section{E-O atendimento é resolutivo e universal (G7, G8, G14, G15).}

Nós somos apenas uma unidade mista com internação por observação e esses pacientes permanecem mais do que uma internação, dando resolutividade dentro do serviço. E não recebemos AIH. Então, é lógico que por a gente ser uma unidade mista de saude, a gente tem que encaminhar e nosso ponto de referência é Botucatu, mas nós damos grande resolutividade, com prosseguimento aqui mesmo.

A gente está adquirindo cada vez mais especialidades para os próprios usuários do SUS. Então, a gente está tentando ver se o usuário tire o máximo daqui, fique o máximo, para não precisar ser transportado para a Unesp e fique na fila lá...

Agora, o atendimento aqui é universal, não tem nenhum tipo de divisão, ou de preferências e até o momento eu não encontrei nenhum tipo de queixas.

A gente tenta facilitar para todos, principalmente aqueles casos que, se a gente não desse recurso, eles não poderiam estar utilizando o serviço.

As desigualdades de acesso aos serviços de saúde desta região são reconhecidas pelos gestores que apontam, dentre outras causas, a desarticulação dos serviços, sua oferta insuficiente e até mesmo iniqüidades produzidas por serviços que dão maior atenção a pessoas com melhores condições sociais e econômicas. Logo, o acesso torna-se desigual, existindo o favorecimento para os mais bem posicionados ou para os que chegam primeiro. As desigualdades no consumo de serviços de saúde, produzidas pela oferta insuficiente e pela má qualidade da assistência, devidas às deficiências de recursos materiais e humanos, acabam por produzir mais desconforto, sofrimento e dor. A eqüidade em relação à qualidade de cuidados pressupõe que cada individuo tenha igual oportunidade de ser selecionado para a atenção à sua saúde, mediante procedimentos justos, decorrentes de suas necessidades e não de sua influência social (WHITEHEAD 1992).

Considerando-se que a eqüidade é um principio ético que instrumentaliza o direito à saúde, os serviços de saúde precisam estar disponíveis para o atendimento das necessidades dos usuários e estruturados segundo níveis de atuação e de densidades tecnológicas. Deste modo, a atenção primária deve estar desconcentrada e 
descentralizada e os níveis secundários e terciários concentrados e centralizados (TRAVASSOS 1997, MENDES 2001).

Observando os dados encontrados na análise da demanda aos serviços de Urgência/Emergência, verifica-se que essa lógica de organização não está sendo seguida na região. Isto é explicado por gestores entrevistados pela oferta insuficiente de serviços, tanto em número de UBSs quanto ao seu potencial de cobertura, o que promove uma inversão na hierarquia da assistência, ou seja, a "substituição" do atendimento nas UBSs pelo atendimento em Pronto Socorro.

Esta situação que persiste principalmente em Botucatu é vista como uma acomodação do município em adequar sua oferta, por contar com a retaguarda do $\mathrm{HC}$ - FMB. Essa acomodação traz, como conseqüência, a sobrecarga dos serviços de Urgência/Emergência e Triagem de Especialidades do HC - FMB. Estes dados apontam para a premente necessidade de organização do sistema municipal de saúde de Botucatu.

Mediante observação dos serviços de saúde dos municípios participantes deste estudo e falas de gestores, alguns municípios menores desta região, por possuirem Unidades Mistas, desenvolvem atendimento mais resolutivo, com melhor acessibilidade da população, preocupando-se com os encaminhamentos considerados desnecessários de doentes para outros municípios. Parece haver melhor acolhimento e maior envolvimento dos profissionais com os usuários, talvez pelas características do atendimento que inclui cuidados diretos ao doente acamado nos leitos de repouso dessas unidades, além do seu funcionamento ininterrupto, o que fortalece os vínculos entre prestadores de assistência e usuários. $\mathrm{O}$ atendimento prestado nas unidades mistas parece aumentar a satisfação dos seus usuários, além de reduzir os custos dos seus deslocamentos para outras cidades.

A existência do Programa Saúde da Família (PSF) em diversos municípios também tem sido considerada relevante para o alcance da equidade da atenção em saúde. Esse programa, que prioriza as ações de proteção e promoção da saúde de indivíduos e famílias, segundo MASSÉ (1995), reduz a demanda aos níveis mais complexos da assistência, dadas as suas ações a partir de prioridades epidemiológicas da área. 
Gestores municipais de saúde reconhecem as vantagens dessa mudança de modelo assistencial, mas deparam-se com dificuldades de caráter político para sua implantação. Tratam-se de questões políticas envolvendo prefeitos, vereadores, "pessoal do planejamento" e secretários municipais. Algumas dessas questões são mais ou menos explícitas, como a que se refere à transferência de recursos das internações para o PSF. Outras são mais veladas, nas quais estão subjacentes as negociações políticas e o clientelismo.

SENNA (2002) ressalta a complexidade do tema eqüidade e justiça social no âmbito do PSF diante das heterogeneidades regionais, econômicas, sociais, políticas e administrativas da história brasileira, concluindo pela necessidade de ações integradas a uma política mais ampla, que garanta os direitos universais para que essas ações não acabem por aumentar as desigualdades sociais.

Neste estudo, observaram-se, ainda, aspectos ligados ao não entendimento do preceito Eqüidade que se traduz em ambigüidades e condutas questionáveis por parte dos serviços em relação aos usuários, destacando-se os relatos feitos por gestores sobre usuários que têm melhores "condições" e procuram a UBS por algum problema de saúde. Como essas "condições" são avaliadas por Assistentes Sociais, conclui-se que estas se referem a condições econômicas e/ou sociais. Estes doentes são orientados para resolverem seus problemas por seus próprios meios, porém, caso tenham consciência dos seus direitos e apelem para o principio constitucional "Saúde, direito de todos e dever do Estado", são atendidos.

A ênfase aos aspectos pragmáticos da regulamentação e implementação do SUS, como observa COHN e ELIAS (2002), é um fenômeno que tem a ver com o esgotamento do ideário original da Reforma Sanitária. Segundo esse autores, a mesma ênfase que tem sido dada ao gerenciamento, à normatização, não tem sido observada quanto ao fenômeno da desigualdade que envolve articulação entre política, saúde e democracia.

Para que a equidade da atenção à saúde seja conquistada nesta região é importante que essa articulação seja buscada, reduzindo, assim, as ambigüidades, os conflitos e as contradições ora existentes. questão:

Os gestores falam sobre a integralidade da assistência ao responderem a 
Como está a integralidade da assistência à saúde no seu município?

Quadro Síntese das Idęias Centrais

\begin{tabular}{|l|l|}
\hline A & $\begin{array}{l}\text { Não tem um foro onde possam ser discutidas integração e racionalização de } \\
\text { scrviços. }\end{array}$ \\
\hline B & A integralidade existe em alguns setores. \\
\hline C & $\begin{array}{l}\text { Na integralidade de ações básicas a gente tem o problema das especialidades } \\
\text { e fica dificil oferecer atendimento integral. }\end{array}$ \\
\hline D & $\begin{array}{l}\text { A atenção integral ainda está na programação, as pessoas não têm } \\
\text { compromisso. }\end{array}$ \\
\hline E & Hoje eu vejo uma integralidade no sistema. \\
\hline
\end{tabular}

A - Não tem um foro onde possam ser discutidas integração e racionalização de serviços (G1, G3, G5, G10, G13).

No nosso municipio observamos vários segmentos do serviço de saúde, cada um meio trabalhando em cima da sua perspectiva, quer dizer, então não tem um foro, onde possa ser discutida, por exemplo, a questão de integrar o serviço, de racionalizar serviço.

A integralidade da assistência também não é garantida, talvez, porque existe uma segmentação de responsabilidade, que eu não gosto muito dela para te falar francamente, porque você discute e alguém fala assim: A atenção básica é do municipio, a atenção secundária é do estado, a atenção terciária é... O paciente não é nem estadual, nem municipal, nem federal e quando ele procura alguma coisa ele não sabe se aquilo que ele procura é da atenção básica, da secundária, da terciária, ele procura a assistência médica. Acho que dentre os principios SUS, infelizmente nós não conseguimos dar conta de nenhum, me desculpe.

Os casos mais complexos vão para a Unesp, para outro município fora da região, mas a gente procura aqui resolver. Muitas vezes a gente fica confrontando este municipio, o outro .... Todo mundo no outro é ruim... Então isso para nós chega a ser muito frustrante, porque o paciente está lá à mercê.

Mas há também uma ociosidade grande de leitos, pela distribuição dos leitos e porque a maioria dos médicos, que é do corpo clinico do hospital, não tem interesse, ou não tinha, eu espero que esteja mudando isso, em fazer atendimentos pelo SUS. 
Alegam que o SUS remunera mal, que remunera pouco, que eles têm um trabalho grande para receber pouco dinheiro, então, eles não se interessam em fazer.

B - A integralidade existe em alguns setores (G2, G6, G8, G9, G10, G13, G14, G17).

A integralidade até existe em alguns setores, como assistência à gestante, assistência ao parto, ao puerpério, a maternidade, o serviço de ginecologia-obstetricia é uma coisa tranquilla, flui muito bem.

Temos bons relacionamentos com as cidades, temos bons atendimentos. Existem algumas divergências, alguns casos que geram problema, mas ai já faz parte do sistema. Não é que gera problema, existe uma dificuldade para resolver de imediato, são coisas que demoram. Paciente que passa muitas vezes no ambulatório do P.S, está indo lá por quê se ele tem a unidade de referência do PSF para se consultar? Por que ele prefere vir até o ambulatório do PS? Uma das medidas que a gente fez para tentar coibir esse tipo de ação foi de não aceitar a retirada na farmácia municipal com a receita do PS alguns medicamentos de doenças crônicas, hipertensão, diabetes. Então, o paciente só retira o medicamento para esse tipo de doença com receita do médico do PSF, quer queira ou não queira, ele vai ter que ir lá no posto do PSF para estar retirando a receita do medicamento.

$\dot{E}$ feito tudo, atendimento de crianças, mulheres, adultos, atendimento de pronto socorro, urgência e emergência. Quando não temos, contatamos uma ambulância para transferir na hora, mas tentamos resolver tudo. A gente procura atender tudo aqui. Dar o primeiro atendimento e dai a gente encaminha.

\section{$\mathrm{C}$ - Na integralidade de ações básicas a gente tem o problema das especialidades e fica difícil oferecer atendimento integral (G2, G7, G10, G12, G15, G16).}

$O$ atendimento hierarquizado por complexidade crescente, quando necessário, é um problema muito sério. Na Unesp nós temos umas quotas, essas quotas são para algumas áreas absolutamente insuficientes, porque têm algumas áreas que já fecharam este ano já não tem mais agendamento. Por exemplo, cirurgia vascular, só 
se for emergência, oftalmologia tem uma demanda muito grande que não consegue dar conta. Eu não sei exatamente qual o agendamento para mamografia, mas eu sei que é ao redor de uım ano, o que torna impossivel você investigar patologias, mesmo as básicas, no nivel da rede básica de saúde. Se você precisar, por exemplo, para investigar uma patologia, de um ultra-som, o agendamento é mais ou menos esse. $\dot{E}$ um agendamento de um ano, o que torna inviável esse tipo de atenção. Isso explica o desespero dos pacientes, passando de serviço $\mathrm{em}$ serviço e muitas vezes sobrecarregando as portas abertas do Pronto Socorro da Unesp.

A prefeitura pode fazer muito pouco nisso. Nós temos só a gestão de rede básica, a gestão da atenção primária apenas. Toda a parte hospitalar, toda a parte de cirurgia, toda a parte de exame complementar mais complexo, toda a parte de medicamentos mais complexos, que é financiada pelo SUS com o dinheiro para atenção secundária e terciária, média complexidade 1,2 e 3 e para alta complexidade, todo esse dinheiro não vem para a prefeitura, não vem para a secretaria municipal.

Ao longo da história da saúde em Botucatu, a média complexidade e alta complexidade foram responsabilidade prioritária da Unesp

A gente tem um bom atendimento, mas ainda falta um pouco mais de agilidade por parte do municipio de referência e também da Unesp, tendo em vista algumas pessoas esperarem muito tempo na fila para fazer algum tipo de tratamento. Outra falha, que cu também acho, é que a pessoa começa a fazer um tratamento na Unesp e é muito demorada a alta desse paciente.

$\mathrm{Na}$ integralidade de ações básicas a gente tem o problema das especialidades e fica dificil da gente oferecer atendimento integral.

Então, muitas vezes, a gente é obrigado a tomar uma atitude assim: Você tem que aceitar o paciente. Então nós, enquanto secretários, somos acionados: olha, o médico não quer receber esse paciente, a Central não quer transferir esse paciente. A gente começa a perceber que é uma briga entre profissionais e o municipe acaba sendo prejudicado. A ortopedia é um problema seríssimo, tanto no meu município como na minha referência. Nosso municipio é pequeno, com poucos recursos e aquilo que a gente depende ainda de outros municipios, a gente tem dificuldade de conseguir. Com alguns é até na base da briga mesmo. 


\section{D - A atenção integral ainda está na programação, as pessoas não têm compromisso (G4, G5, G10).}

Tem sido mantido um número altissimo de consultas médicas fora da realidade que a gente necessita, um numero altissimo de exames laboratoriais com um percentual baixissimo de positividade, então eu me livro do paciente pedindo coisas e eu acabo ainda tendo um número altíssimo de tratamentos. Se você cruzar essa informação, você verifica que a atenção integral ainda está na programação, as pessoas não têm compromisso.

Quanto ao bio-psico-social é feito, nas unidades básicas, por exemplo, é feita uma abordagem do ponto de vista bio-psico-social, mas com insuficiências, no meu modo de entender. O centro de saúde era muito mais dinâmico, ele atuava muito mais fora, hoje ele tem visita, tem isso, tem aquilo, mas é em poucos casos, o pessoal alega que não tem tempo para isso. E com o aumento da demanda ao centro de saúde, sem o concomitante aumento de pessoal, os funcionários, os médicos, enfermeiros, auxiliares preocupam-se, mas não executam isso com a intensidade que deveria ser.

Então, se eu atendesse aquele paciente da forma como eu precisaria atender...

Também um pouco disso é porque os nossos municípios não têm atrativos, os profissionais têm vários empregos, ele não tem uma responsabilidade sobre aquela população, ele circula em vários municipios ao mesmo tempo.

Nós temos muitos erros e eu percebi assim, os profissionais mais antigos são os profissionais que nos dão mais problemas, porque eles não entendem que hoje você trabalha com referência e contra-referência. Isso será superado a partir do momento em que a gente passar a ter a saíde da família. O agente comunitário de saúde tem um papel importante nisso, ele pega desde o aspecto de como a pessoa mora, como a pessoa se relaciona, como é que ela se relaciona na comunidade, a escolaridade, todos os aspectos ligados às pessoas e às familias, nos aspectos sociais, nos aspectos sócio-econômicos, tal, até o estilo de vida, lazer, saúde mental e a saúde então, o fisico, o biológico. 


\section{E - Hoje eu vejo uma integralidade no sistema (G5, G11).}

Hoje eu vejo uma integralidade no sistema, porque os médicos do Centro de Saúde são os mesmos que trabalham no Pronto Socorro, então eu vejo que existe uma boa integralidade no sistema.

Todos os serviços estão integrados com a própria referência e contra-referência da unidade ambulatorial especializada, com os médicos do PSF... Eu vejo isso como um dos maiores exemplos da integração que existe.

Porém, a evolução maior de integrar a região foi essa Central de Regulamentação. Porque até então os meus pacientes tinham que ir para Avaré ou Botucatu. Hoje não. Hoje já é comum a população aceitar uma transferência para o município de referência mais próximo. A PPI (Programação Pactuada Integrada) é uma forma de integrar melhor o sistema. Porque eu sei que o Ministério desconta dinheiro meu para uma AIH de paciente internado na Unesp, mas eu não sei quanto. À partir da PPI eu sei. Eu sei quanto o meu municipio está investindo na Unesp. Isto vai fazer com que os municipios invistam mais nos seus sistemas, porque enquanto uma AIH minha custa 440 reais, na Unesp custa 970, se não me falha a memória. Então, é melhor eu tentar investir melhor aqui que vai ficar mais barato o tratamento desse paciente. E investir como? Investir na saúde secundária? Não, investir na primária, investir nos profissionais, investir no centro de saúde, em treinamento, para a gente poder realmente abrir o leque da prevenção.

De acordo com TEIXEIRA (2002) a proposta de regionalização da assistência deve ser discutida visando a construção de um modelo de atenção que não se limite a garantir a assistência - "atenção promovida no lugar certo, no tempo certo, na qualidade certa, com custo certo" (MENDES 2001 p.104) - mas à integralidade da atenção à saúde que prevê movimentos em direção à promoção da saúde.

A integralidade da assistência à saúde, ainda entendida apenas como assistência médica curativa e individual a uma demanda espontânea, é considerada fragmentada pelos gestores. Estes comentam as diferentes lógicas de atuação de cada serviço de saúde e a diluição das responsabilidades pela assistência aos usuários do sistema. Há falta de comunicação e de alianças entre os serviços da rede básica e 
destes com os serviços de média e alta complexidade, inviabilizando a atenção contínua aos doentes. $\mathrm{O}$ acesso aos serviços secundários e terciários, tanto para consultas médicas quanto para exames complementares é complicado pela falta de vagas e, conseqüentemente, os agendamentos são feitos em prazos muito longos. Destacam-se aqui as consultas nas especialidades de cirurgia vascular, ortopedia e oftalmologia e os exames de ultra-som e mamografia. Esta situação tem gerado o desespero e a busca de vários serviços pelos usuários.

Em áreas da assistência médica, como saúde materno-infantil, a integralidade é mais facilmente conseguida, talvez, pela própria cultura existente de priorização dessas áreas.

Embora demonstrando um entendimento parcial do conceito de integralidade da assistência à saúde, os gestores identificam muito bem a fragmentação do sistema de serviços de saúde, que segundo MENDES (2001), "divide o evento da doença e a atenção por partes que não se comunicam" (p.73).

A falta de pessoal para atender a demanda também é apontada como barreira à integralidade, levando os profissionais a apressarem os atendimentos dos usuários. Por mais esta razão, dentre outras que não serão listadas aqui, os profissionais, movidos pela insegurança do rápido atendimento, solicitam um grande número de exames subsidiários com "baixissimo percentual de positividade".

Encontram-se, ainda, resistências entre profissionais dos serviços de saúde ao trabalho integrado e à adoção de condutas que viabilizem mecanismos de referência e contra-referência. Persiste a cultura do modelo médico assistencial privatista $\mathrm{e}$ independente, com sérias dificuldades para mudanças em direção à integralidade da assistência à saúde.

Interesses financeiros, como o interesse pelo recebimento do valor da $\mathrm{AIH}$, uma vez que a NOAS 2002 estabelece que "o limite financeiro por municipio deve ser gerado pela programação para o atendimento da própria população, deduzida da necessidade de encaminhamento para outros municipios e acrescida da programação para atendimento de referências recebidas de outros municípios" (BRASIL 2002, p.11) podem produzir situações de conflitos entre gestores, profissionais e usuários que solicitarem encaminhamentos para atendimento médico em outros municípios. 
Outras atitudes e condutas visando ao "disciplinamento" do usuário poderão ter conseqüências negativas, dado seu caráter autoritário e burocrático, como no caso citado, em que um usuário atendido em um serviço de urgência, portador de uma doença crônica, só poderá retirar o medicamento no serviço de saúde se a receita for feita por médico do PSF, obrigando-o, deste modo, a se vincular ao PSF.

Por outro lado, alguns movimentos estão sendo feitos em direção à transformação do modelo de atenção à saúde, com vistas à integralidade da assistência e à promoção da saúde. Como exemplo, são citados, dentre outros, o aumento de equipes do PSF, o empenho da Central de Regulação Médica no gerenciamento da alocação dos doentes com necessidades de atendimento urgente e as pactuações entre os municípios da região, coordenadas pela DIR XI.

Acredita-se que a implementação do Cartão Nacional de Saúde contribuirá com a integração dos serviços de saúde, por possibilitar o acompanhamento das referências intermunicipais, oferecer subsídios para a Programação Pactuada Integrada (PPI) e possibilitar o acompanhamento do fluxo dos usuários nos serviços de saúde (BRASIL 2000).

A percepção dos gestores sobre a qualidade da assistência à saúde é apresentada na resposta à questão:

\section{Como está a qualidade da assistência à saúde no scu município?}

\section{Quadro Síntese das Idéias Centrais}

\begin{tabular}{|l|l|}
\hline A & Existe qualidade em alguns serviços, mas falta a quantidade. \\
\hline B & A qualidade é muito difícil de medir. \\
\hline C & A qualidade ainda deixa a desejar. \\
\hline D & A qualidade da assistência tem a ver com profissionais de saúde. \\
\hline E & $\begin{array}{l}\text { Há, claramente uma substituição da história, da propedêutica, do exame } \\
\text { físico, pelo exame. }\end{array}$ \\
\hline F & O excesso de pedidos de exames reflete a qualidade do atendinento. \\
\hline G & A qualidade do serviço prestado é boa. \\
\hline
\end{tabular}


A - Existe qualidade em alguns serviços, mas falta a quantidade (G1, G2, G3, G10).

Existem serviços no município onde a assistência tem qualidade, mas o parâmetro da quantidade indica que não existe qualidade sem quantidade. A maioria dos serviços públicos, não apenas a saúde, se organiza segundo uma formulação interna. Dentro daquilo que o serviço se propõe, quem é atendido, tem atendimento de boa qualidade, mas não está se perguntando se aquilo que está sendo oferecido é o adequado para a população. Então, eu morro de dó quando pacientes de outros municípios vêm aqui, porque no município deles eles sabem que não vão ter a assistência que precisam. Mas eu não posso atender porque o meu convênio é para os nossos municipes.

\section{B - A qualidade é muito difícil de medir (G3, G5, G9, G14).}

O conceito de qualidade é uma questão muito ampla, eu não consigo relatar muito bem. A qualidade no municipio fica dificil para a gente classificar, ela talvez seja um pouco dificil de medir, é uma coisa muito dificil de avaliar e controlar. Porque a hora que a pessoa entrou dentro do consultório e fechou a porla, só se você estiver presente para fazer a avaliação da consulta, e você não consegue estar presente em todos os consultórios e também estar presente iria causar um problema, pois enquanto tiver uma pessoa observando, faz tudo direitinho e depois quando a pessoa não tiver mais observando, não faz.

Em vários municipios se subentende que se o paciente é bem atendido e os seus problemas são bem resolvidos, o paciente não teria que voltar a uma consulta assim, tão rapidamente. Mas, lamentavelmente, acredito que seja um pouco da cultura daqui do Brasil, o paciente gosta de voltar, então confunde um pouco qualidade com o retorno habitual que eles têm. Eu tenho muita gente que vem consultar às vezes, pondo em dívida a qualidade do atendimento do Centro de Saude ou do Posto Médico, não porque somos ruins, mas porque é costume consullar duas ou três vezes. 


\section{C - A qualidade ainda deixa a desejar (G3, G4, G11, G15).}

Se você considerar, por exemplo, qualidade da assistência como resultado final de uma assistência, por exemplo, o paciente tinha uma cirurgia para ser feita, ele saiu bem da cirurgia, a qualidade foi boa? O resultado foi bom, mas talvez a qualidade não tenha sido boa. Quanto tempo esse paciente demorou para ser atendido? Quais foram os percalços que aconteceram até ele chegar ao médico? Quer dizer, se isso entra na qualidade, ela é muito mim. Muito ruim no municipio e inclusive aqui no hospital.

A qualidade ainda deixa a desejar, porque eu não vejo a questão da humanização sendo contemplada dentro das nossas unidades. Tem municipios que a saúde é inclusive um mote politico. Mas tem uns que fazem com que o nosso atendimento seja o tempo todo criticado. Então, se hoje eu acolhesse melhor as pessoas, eu ouvisse melhor o que a pessoa está indo fazer na nossa unidade, com absoluta certeza teria menos consulta, teria menos medicação sendo prescrila, menos calmantes sendo prescritos, porque as pessoas vão procurar as portas abertas. Hoje a gente tem uma série de programas de incentivo, coisa que no meu entender, é nossa obrigação, eu não tenho que ser incentivada a atender bem, eu não tenho que ser incentivada a uma humanização do parto, isso tem que ser inerente à minha atitude profissional.

Vou dar um exemplo para você: há uns 3 meses atrás, eu estava na frente do centro de saúde, saiu uma senhora do consultório médico com uma receita, passou na frente e jogou a receita. Eu peguei a receita e fui conversar com a senhora. Ai eu falei: - Senhora, a senhora teve algum problema com o médico que a atendeu que a senhora jogou a receita? Ela falou: Não, eu fui tão bem atendida que eu não preciso da receita.

Eu sei que ainda tem muila critica, não só em termos de saúde, mas de uma maneira geral. Mas eu percebo que houve um grande ganho, uma grande evolução, mas nós temos muito que caminhar. 
D - A qualidade da assistência tem a ver com os profissionais de saúde (G4, G5, G11, G16).

A qualidade é muito variada, vamos pegar a atenção básica. Nós temos alguns profissionais, sejam enfermeiros, auxiliares de enfermagem, médicos, dentistas, auxiliar de cirurgião dentista da equipe da rede pública municipal que fazem um atendimento de boa qualidade, eu diria de ótima qualidade, com acompanhamento, têm interesse, se desdobram para fazer o encaminhamento quando o caso é grave. A maioria dos funcionários da rede municipal faz esse tipo de atendimento de boa qualidade. Agora, nós temos alguns profissionais que fazem um atendimento, eu diria, burocrático. É dificil corrigir isso, porque as pessoas que poderiam corrigir isso seriam as chefias das unidade, porém, em algumas unidades os enfermeiros dizem: Olha, eu estou aqui como chefe, mas eu não ganho para isso. Eu ganho como enfermeiro, eu tenho uma função de chefia, mas não ganho para isso, eu não tenho perfil, eu não quero brigar com as pessoas.

Não posso generalizar porque existem vários funcionários, seja médico, seja auxiliar ou enfermeira, que se dispõem a atender as pessoas da melhor forma possivel. Normalmente, na rede básica todo mundo quer atender de forma rápida porque tem que ir embora, principalmente a classe médica e acaba que não dá atenção suficiente ao paciente para resolver um problema, que às vezes é um pouquinho mais complicado, foge daquele nível de normalidade dos problemas, da diabetes comum, da hipertensão, daquelas coisinhas, da esclerose e doenças cardiovasculares. Nós temos um problema muito sério sob dois aspectos: sobre a qualidade do atendimento e sobre o horário. No começo da gestão a gente falou: São t horas, são t horas. É para cobrir t horas, senão já cortamos o ponto e nós vamos cortar o ponto através das chefias das unidades. Médico chegou tal hora, saiu tal hora, a diferença era descontada. Tivemos um problema, que em decorrência dessas brigas o pessoal deixou de anotar. Então, hoje, não está tendo desconto e, alguns poucos profissionais, estão cobrindo 2 horas, em alguns casos 1 hora e meia.

Então eu acho que ainda tem muito o que investir na qualidade e nós buscamos alternativas para melhorar a qualidade. A primeira coisa que eu achei, para trabalhar melhor a qualidade, é que há pouco tempo atrás só tínhamos atendentes, 
nós não tínhamos enfermeira, então, a primeira coisa para melhorar a qualidade foi capacitar todo o nosso pessoal como auxiliar de enfermagem e contratar enfermeira. Mas é muito caro manter esse atendimento, nós precisamos de mais profissionais médicos. Principalmente médicos, nós temos uma dificuldade muito grande para segurá-los aqui e eu estou com uma dificuldade enorme para contratar uma enfermeira. Abrimos um concurso público e não conseguimos nenhuma inscrição. $O$ custo é alto, mas também é dificil conseguir um profissional. Hoje, dos dois pediatras que a gente contratou no ano passado, um atendia 3 vezes por semana mas ele veio me dizer hoje que ele vai atender agora uma vez por semana. Então está complicando para a gente, porque a demanda é grande para um profissional. É onde começa a cair a qualidade no atendimento. Eu acho que nós temos uma universidade, a Unesp ai tão pertinho, e tanta gente se forma e a gente não consegue trazer ninguém para cá.

\section{E - Há, claramente uma substituição da história, da propedêutica, do exame físico, pelo exame (G5, G10).}

Uma das coisas que nós estamos montando agora no sistema de avaliação é começar a controlar quantos exames são pedidos por consulla em média. Alguns médicos pedem um exagero de exames, o que acarreta um custo, não é? Esse custo não incide no municipio, mas incide na DIR. A DIR já me cobrou várias vezes, que tem unidades onde não sai uma consulta sequer sem um pedido de exame, e na maioria das vezes 5, 6, 7 exames. Isso claramente é uma substituição da história, da propedêutica, do exame fisico, pelo exame.

Mas a gente tem munícipes que só vão se sentir assistidos se eles sairem com uma receita cheia de medicamentos, cheia de exames para fazerem. Só que quando a gente convida para fazerem parte de um grupo de orientação para prevenção da doença, eles não vão. 


\section{F- A qualidade do serviço prestado é boa (G6, G7, G8, G9, G10, G12, G13,G17).}

Quanto à qualidade da assistência prestada pelo município eu acho que ela é muito boa. Inclusive o municipio procura dar uma qualidade tendo ginecologistas quase todos os dias, pediatra todos os dias, exames de ultra-som, para eles não ficarem na agenda de Botucatu esperando muito tempo. Os exames de mamografia, a gente já encaminha para São Paulo, porque nossa quota é insuficiente. Então eu acho que a qualidade da saude aqui no nosso município, dentro das nossas possibilidades, eu acho até que a gente oferece bem mais do que aquilo que nós deveriamos ou poderiamos estar oferecendo. Isso acaba tendo um custo muito grande para o municipio, e hoje nós gastamos no mês, para todos os serviços, plantonistas e tal, uma faixa de 90 a 100 mil reais, para manter a saúde aqui, com todos os exames, enfim, incluindo todas as despesas da saúde.

Pelas informações que a gente tem, creio que em 70 a $80 \%$ está ótimo o serviço do municipio. Agora com relação aos que a gente encaminha aos pontos de referência, também classifico ai uns $70 \%$ ótimo.

Então, eles não têm muito o que reclamar não. E se tiverem, a minha sala é aberta a todo mundo que entrar aqui, que quiser vir para conversar, tiver algum problema a gente vai tentar resolver.

Eu acredito que está boa porque sempre o prefeito vai para a rádio dar entrevista para a população e a saúde não é muito cobrada, então a gente acredita que está satisfatória, porque a gente tem médico todo o dia, tem enfermeira...

Se você for hoje em qualquer unidade de saúde da familia, principalmente na região central da cidade, que é onde está a população de poder aquisitivo melhor, você vai ver que muitas das pessoas que estão lá são pessoas de boa condição financeira. Eu meço isso, primeiro, pelo problema financeiro, segundo, pela qualidade do serviço prestado. A qualidade do serviço prestado é boa, as consultas são diferentes das realizadas, inclusive em consultório particular, são consultas de no mínimo 15 minutos, e no pré-natal são consultas de 30 minutos.

A gente está partindo muito para essa parte preventiva, saúde pública está falida no Brasil. Então, com a prevenção, você consegue resolver e selecionar o que é mais grave para você atender. 
Em termos de regional, eu acredito que é muito boa a qualidade, tendo em vista que nós temos bons médicos tanto em Avaré como em Botucatu na Unesp. Acredito que falta um pouco mais de integração por parte dos três niveis.

Novamente é apontada a desarticulação dos serviços e suas diferentes lógicas de atuação, já mencionadas nas respostas à pergunta sobre a integralidade da assistência à saúde. Agora, porém, referindo-se aos reflexos desta questão sobre a qualidade da assistência. São feitas, também, referências à qualidade da assistência sem a necessária "quantidade".

Considerando-se a polissemia do termo qualidade e sua relação com a quantidade, "quantidade, para qualidade, é base e condição" (DEMO 1999, p.10), entende-se que as avaliações da qualidade dos serviços devem considerar: universalidade de acesso, eqüidade, integralidade da assistência, resolutividade em todos os niveis da assistência, competência dos profissionais, satisfação dos usuários, eficácia, eficiência e adequação (GATTINARA ET AL. 1995; AKERMAN E NADANOVSKY 1992).

Ao expressarem suas dificuldades para avaliação da qualidade dos serviços que dirigem, os gestores revelam suas limitações, tanto para a avaliação objetiva, mensurável, quanto para a avaliação subjetiva, que pressupõe o uso de elementos que permitam conhecer a interação dos atores - usuários, profissionais e gestores - com os programas e serviços de saúde, suas percepções e expectativas (UCHIMURA et al. 2002). Assim, desenvolvem-se critérios de avaliação da qualidade baseados $\mathrm{em}$ induções vulgares e preconceituosas, tais como: "se o paciente não retornar logo é porque o atendimento foi resolutivo"; "a qualidade é boa porque ninguém está reclamando"; "brasileiros gostam de retornar várias vezes ao serviço de saúde", sem que seja levantada a questão sobre o por quê dos retornos, mesmo quando considerados "desnecessários". O autocuidado está sendo estimulado, ou continua sendo praticado o paternalismo que historicamente caracteriza as relações entre profissionais de saúde e clientes?

A escassez de recursos materiais e humanos e a existência de profissionais pouco compromissados com o atendimento da população são apontadas como colaboradores para a perda da qualidade. Depara-se com a falta de mecanismos eficientes de supervisão, que possibilitem a identificação de comportamentos 
inadequados e a tomada de medidas saneadoras. Essas medidas, em algumas situações, precisam ser de caráter punitivo, visto ferirem, muitas vezes, a dignidade dos usuários, dos profissionais e da instituição pública, porém, são muito difíceis de serem tomadas, principalmente em relação ao profissional médico. Segundo GAUDERER (1991) isto se deve ao fato desse profissional de saúde ter status c prestígios especiais decorrentes do seu "poder de curar". Assim, quando questionado, esse profissional poderá apresentar reações indesejáveis, tanto em direção aos demais membros da equipe, afetando o relacionamento interprofissional, quanto em relação ao paciente, com atitudes de abuso de poder e decisão unilateral sobre o que considera melhor para o paciente, sem uma discussão mais ampla sobre as condições desse paciente e suas possibilidades. Em decorrência disto, muitas denúncias não são formuladas, havendo acobertamentos e cumplicidade pela falta do entendimento de que a lealdade no serviço de saúde deve ser, em especial, ao usuário.

A humanização do atendimento ou o acolhimento do usuário é uma dimensão da qualidade que, no momento atual, implica em redefinição do processo de trabalho em saúde ancorada no conhecimento de problemas e necessidades sociais de saúde de indivíduos, famílias e grupos da população, observando-se, além da dimensão técnico-cientifica, a dimensão ética do trabalho em saúde (SHRAIBER 1993; TEIXEIRA 2002).

Os avanços da ciência e da tecnologia têm contribuído para melhorar a assistência e aumentar a sobrevida, mas têm enfraquecido os vínculos dos profissionais de saúde com os usuários, porque o atendimento tem sido impessoal e fragmentado em especialidades e subespecialidades. A lógica do mercado, que desencadeia a elevação dos custos da assistência à saúde em todos os níveis, com vistas ao lucro, cria nos profissionais e nos usuários necessidades de consumo de exames e medicamentos e estas, quando não satisfeitas, suscitam suspeitas em relação à qualidade da assistência. Ao problematizarem essa situação, os serviços de saúde buscam estratégias de resolução, como a citada pelos entrevistados, de formação de "grupos de prevenção", mas ressentem-se do desinteresse demonstrado pelos usuários em participar dos mesmos. Entretanto, essa atividade, também chamada de educação em saúde, não tem sido desenvolvida nos municípios da região com o objetivo de ampliar o poder popular e sua participação nas decisões relativas à 
assistência à saúde. Continuam desenvolvendo a chamada "educação sanitária" mediante comunicações rápidas durante o atendimento do usuário, ou em salas de espera por meio das "aulinhas para os pacientes", ministradas por estudantes e estagiários, principalmente de enfermagem, ou em grupos específicos de autocuidado, quando são transmitidas informações em palestras proferidas por um profissional de saúde. Há uma certa pressão para que os usuários participem dessas reuniões, nas quais eles ouvem passivamente um monólogo repleto de advertências. As possibilidades de transformação do paciente em agente de sua própria saúde ficam, deste modo, um tanto reduzidas e os movimentos em direção à qualidade da assistência à saúde muito lentos e pouco vigorosos.

A questão em seguida apresentada aos gestores foi:

Como está o controle social da assistência à saúde no seu município?

Quadro Síntese das Idẻias Centrais

\begin{tabular}{|l|l|}
\hline A & O controle social é incipiente. \\
\hline B & Algumas unidades de saúde avançaram nas estratégias de controle social. \\
\hline C & $\begin{array}{l}\text { Estamos aguardando a promessa do Ministério da Saúde de capacitar os } \\
\text { conselheiros. }\end{array}$ \\
\hline D & $\begin{array}{l}\text { O Conselho Municipal de Saúde teve sua composição e funcionamento } \\
\text { reformulados e o controle social aumentou. }\end{array}$ \\
\hline E & $\begin{array}{l}\text { As Conferências Municipais de Saúde e os Conselhos Municipais de Saúde } \\
\text { apresentam diretrizes para o controle social. }\end{array}$ \\
\hline F & O CMS é funcionante. \\
\hline
\end{tabular}

A - O controle social é incipiente (G1, G2, G11).

A minha divida é assim, se realmente esse controle existe de fato e se ele é social, ou simplesmente num segmento corporativista, alguma coisa assim, porque eu não tenho certeza se ele representa mesmo os usuários, eu coloco isso em questão, é pouco participativo.

O controle social que eu tenho observado é incipiente. Nas unidades mais perifericas de sauide daqui, ainda existe aquele conceito de beneficio. As pessoas agradecem pelo beneficio recebido de uma consulta médica, da vacinação, de uma orientação. 
Eles não se sentem com capacidade ou com competência para interferir em qualquer ação ou produto que o serviço possa oferecer. E o serviço, por outro lado, observa a população como não participativa, como se não tivesse interesse, e não procura aumentar essas áreas de interface com a população.

O controle social eu acho que está com bastante deficiência, porque quando a gente fala que a qualidade não está boa é porque o meu controle social também é falho. Hoje eu costumo dizer o seguinte: não há como desvincular a saúde do social e da educação. É impossível, se nós tivermos pessoas mais cultas, melhor educadas, com certeza vai bater de encontro com a saúde. Por exemplo, nós estamos cansados de ver pessoas que no primeiro sintoma de febre de uma criança corre para o médico. E eu não tenho um diagnóstico social exato da saúde da minha população. Temos hoje o pessoal trabalhando em conhecer melhor a população. Tem umas assistentes sociais do municipio que já têm acompanhado nosso trabalho. Então, eu acho que ainda falta muito para falar: eu tenho controle da minha população, eu tenho controle do que acontece tanto na questão da saúde, da educação, do social, infelizmente, hoje, nós não temos um controle exato disso tudo e o Conselho Municipal de Saúde ainda é papel.

B - Algumas unidades de saúde avançaram nas estratégias de controle social (G2, G3).

Tem algumas unidades que já avançaram bastante, por exemplo, o Centro de Saúde Escola. Eu acho que o Centro de Saúde Escola tem o interesse em avaliar as suas ações e permitir que a população da sua área de abrangência tenha uma participação efetiva na sua programação e cria, às vezes, algumas épocas mais, outras menos, mecanismos de incentivar a participação popular e durante esse processo de participação ir aperfeiçoando os mecanismos de participação e a sua programação. O Conselho tem os membros que representam os diferentes setores da saúde e eles são uma expressão, praticamente, do que acontece dentro da sociedade. 
Mas tem um problema, essa tecnologia que eles desenvolveram, ela não está sendo repassada para as outras unidades do municipio. Ai a participação social fica exigua.

Ai você fala como o Conselho é feito? É uma Conferência Municipal? Não, são pessoas convidadas pelo prefeito e não são pessoas esclarecidas, eles participam das reuniões quando nós convocamos. Eu acho que Conselho não é para isso. Eu, como secretário, tenho que ser convocado pelo Conselho. Ai cu acredito que vai começar a funcionar alguma coisa entendeu? Tipo assim, o Conselho não tem que esperar eu ir lá. Ele tem que ajudar a fiscalizar a situação da saúde, planejar a saúde, enfim, fazer a saúde no municipio.

Eu ainda acredito que o controle social, por exemplo, via Conselho Municipal de Saủde, é um fórum pouco deliberativo, na minha opinião, ele delibera muito pouco.

\section{C - Estamos aguardando a promessa do Ministério da Saúde de capacitar os conselheiros (G3, G4, G10, G11, G13, G14, G15, G16).}

Estamos aguardando uma promessa do Ministério da Saúde de algum tempo atrás, de fazer a capacitação dos conselheiros. Infelizmente, essa capacitação seria na Unesp, porém, a última noticia é de que vai ser em Campinas. Se for em Campinas vai ser impossivel nosso município participar, assim como para outros municípios. Quer dizer, nós vamos continuar tendo um Conselho que não vai ser participativo e, principalmente, vai ser um Conselho que não vai nos ajudar em nada. Eu acredito que de todos os 30 municípios só tem um ou dois que funciona mais ou menos, os outros estão tudo na mesma situação.

Acho que os conselheiros são pouco informados, talvez pela própria participação, eles são segmentários, eles vêem o problema daquele bairro, que eu não sei se representam. As decisões, quando acontecem, acho que são decisões consentidas, $e$ quando polêmicas elas são, de uma certa maneira, não trazidas.

O Conselho de Saúde ainda precisa ter um pouco mais de visão. Eu já participei de algumas reuniões, não se oferecem condições para aquela pessoa que faz parte, de alguns conceitos ou subsidios para que ela possa colocar suas idéias e suas propostas de uma maneira mais clara. Então, a pessoa vai lá com uma idéia. Eu 
acho ótimo que vá com uma idéia, mas ela perde ou ganha na hora de colocar sua idéia, porque falta algum embasamento um pouco mais firme em relação ao que se propõe. Fora dos momentos de reuniões, você percebe que tudo é secretaria mesmo, não tem aquele envolvimento maior fora do horário de reunião. Tudo a gente leva, eles participam no momento de reunião, dando seu ponto de vista, dão as sugestões, mas para aí. As reuniões eram bimestrais. Agora, a partir da exigência do ministério, nós mudamos para mensal.

Talvez esse curso que eles estão pretendendo dar para os conselheiros proporcione isso, de eles terem visão de chamar a população.

Acho, também, que as pessoas não entendem muito, e não compreendem o alcance que elas têm na própria mão. Eu acho que os nossos Conselhos Municipais de Saúde ainda precisam ser amadurecidos. E não é só o Conselho, eu acho que nós como cidadãos.

\section{D - O Conselho Municipal de Saúde teve sua composição e funcionamento reformulados e controle social aumentou (G5, G6, G9).}

O controle social tem aumentado muito. Nós temos tido novas lideranças que têm se engajado. Quando nós pegamos a secretaria municipal de saúde, nós tínhamos 3 CONUS (Conselhos de Unidades de Saúde) funcionado, com alguma deficiência, mas funcionava. A gente fez um esforço, e ai eu quero louvar o esforço, o empenho do grupo de apoio aos CONUS, que é constituido de pessoas da Unesp, do Centro de Saúde Escola, Secretaria Municipal de Saúde, pessoas da Secretaria de Assistência Social. Isso se refletiu na renovação do Conselho Municipal de Saúde, inclusive na composição do Conselho. Havia uma série de entidades que estavam no Conselho, mas que eram entidades que não tinham nenhuma ligação com o SUS, não eram próximas, não eram usuárias do SUS, não prestam serviços ao SUS. Então, foi feita uma reformulação. Essa reformulação foi amplamente discutida no Conselho e a comunidade participou muito ativamente. O Conselho Municipal de Saide foi todo reformulado quanto à sua composição e quanto ao seu funcionamento. Hoje, por força da lei vigente, o secretário de saide é automaticamente presidente do Conselho Municipal de Saúde, o que é uma estupidez, porque o Conselho tem um 
papel de trabalhar junto, sim, com a Secretaria, mas ele tem um papel fiscalizador, papel controlador sobre a ação da Secretaria. Enião, a presidência sendo do secretário municipal de saúde, eu acho que isso não é democrático. Então foi alterada a composição do Conselho e da sua direção. O presidente do próximo Conselho já foi eleito e deve tomar posse este mês, no fim deste mês. Vai ter uma comissão executiva, que vai fazer o acompanhamento e a Secretaria vai dar suporte ao Conselho, não vai ser mais como é atualmente, onde a Secretaria se confunde com a coordenação do Conselho.

Ao assumirmos a administração, a legislação que regia o Conselho Municipal de Saúde não era igualitária. Ou seja, o usuário tinha menor poder de voto do que o próprio trabalhador, do que o próprio prestador de serviço, ficava em condição de inferioridade. Nós enviamos um projeto à câmara municipal, foi aprovado, garantimos no minimo 9 usuários no Conselho de Saúde e o resto dividimos entre trabalhadores e prestadores, são 9 usuários e 9 trabalhadores e prestadores. Temos também os Conselhos Gestores das Unidades, com reuniões entre os usuários daquela unidade especifica. Isso é um processo mais lento, que está engatinhando ainda.

\section{E - As Conferências Municipais de Saúde e os Conselhos Municipais de Saúde apresentam diretrizes para o controle social (G5, G6).}

Espero uma grande participação da população na principal instância do SUS no municipio, que é a Conferência Municipal de Saúde. A $3^{a}$ Conferência será realizada agora em Novembro. Pelas pré-conferências en estou animado, estimo que, talvez, umas 300 pessoas vão estar, 300 delegados e participantes de plenárias e tal, e de entidades sociais, de sindicatos, enfim de prestadores de serviço, dos gestores tanto do Centro de Saúde Escola quanto da Secretaria. E este fórum eu acho que vai dar uma grande diretriz para a participação no nosso municipio, com participação popular e com controle social.

Assim que sair da condição de secretário, volto para o Conselho Municipal de Saúde, porque eu vejo que é a saida para todas as dificuldades que a gente tem. Se 
não tiver participação popular, pode implantar o melhor sistema, tem que ser através dos Conselhos.

\section{F - O CMS é funcionante (G6, G7, G8, G12, G13, G17).}

O Conselho é muito ativo, eles estão sempre participando, estão muito entrosados em todos os programas. E a gente, na parte de controle em relação ao Conselho e à saúde, nós não temos nenhum tipo de problema, não. As nossas reuniões são bimestrais. Desde que foi criada a lei do Conselho, a lei determina que as reuniões sejam bimestrais, então até a presente data, nós fizemos reuniões bimestrais, depois tivemos uma avaliação do municipio pela regional de saúde, eles orientaram que o ministério está cobrando reuniões mensais do Conselho Municipal de Saúde.

O Conselho Municipal é funcionante. Eles são bem participativos, são usuários da cidade mesmo. Tem o pessoal do hospital que participa e os usuários do comércio. Eles perguntam, participam, estão bem por dentro da situação da saúde, sim.

Para os membros que não têm muito conhecimento a gente vai explicando e fazendo eles tomarem conhecimento da saúde. Eles participam, fazem perguntas, querem saber e vai indo tudo bem.

Todas as decisões que nós temos que tomar o Conselho participa, inclusive é uma exigência, muitas vezes dos convênios, é uma exigência do governo e, não só por exigência, eu acho que a gente tem que dividir as nossas preocupações com o Conselho, para que eles fiscalizem o dinheiro que vem.

A participação da comunidade na formulação de estratégias e no controle da execução das políticas de saúde é um preceito do SUS, cujos espaços são: A Conferência e o Conselho de Saúde - Lei 8142 de 28/12/1990 - Ministério da Saúde (BRASIL 1991). Entende-se por participação, segundo CORTES (1998), o ato de fazer parte dos processos de decisão política.

Alguns gestores entrevistados indicam que a participação nos Conselhos Municipais, nesta região, é precária, apresentando características corporativistas, representação dos usuários bastante tímida e não observância, pelo menos até há pouco, do caráter paritário da composição dos Conselhos. Entendem que os 
Conselhos Municipais de Saúde (CMS) ainda não saíram do papel, definindo-o, de certo modo, como um grupo de pessoas "convidadas pelo prefeito", as quais deverão comparecer às convocações de reuniões. Deste modo, os Conselhos passam a representar uma extensão do poder executivo ocupado por amigos do prefeito, aspectos já verificados e analisados em diversos estudos (DALLARI 1996; PEDROSA 1997; VALLA 1998). O importante é que ao problematizarem essa situação vivenciada nos Conselhos, os gestores estão dando importante passo para sua superação.

Entre os entrevistados que consideram o CMS do seu município atuante e participativo, seus critérios para essa avaliação apontam para dificuldades de entendimento do significado de participação. Observa-se ainda que a periodicidade das reuniões, citada por estes entrevistados, é definida não pela necessidade, mas por determinação de instâncias superiores.

Estudo desenvolvido em Botucatu por MORITA (2002), sobre o Conselho Municipal de Saúde, reveste-se de grande importância pelo fato deste município vir a ser sede de módulo e pólo e no qual os municípios menores da região tendem a se espelhar. Esse estudo verificou uma "participação tutelada" dos membros do CMS. Observou, também, que entre os conselheiros há os que se identificam por "nós" os quais referem-se aos outros como "a comunidade", passando uma idéia de oposição. Essa autora observou, entre os "nós", grupos de interesse que buscam aproximaremse, inclusive sentando-se lado a lado nas reuniões, e pode identificar que "lideranças não pertencentes ao mesmo estrato social de seus representados tendem a sentar-se próximas aos que se identificam como seus pares" (p. 82) e o grupo do "nós da comunidade" permitiu identificação de proximidade de pessoas com interesses comuns, moradoras do mesmo bairro. Observou que o grupo da comunidade apresentava tendências a suscitar questões e reivindicar melhorias da assistência nos serviços de saúde, as quais, em geral, eram consideradas como "questões menores", priorizando-se, nas reuniões, os temas considerados mais importantes. Tal observação coincide com a da autora deste estudo que, em diversas reuniões das quais também participou, entre 1999 e 2001, pode perceber que a pauta das reuniões, definida pelos técnicos e secretario municipal de saúde, tem prioridade sobre outros 
assuntos, e esta, via de regra, refere-se a informes administrativos, projetos e relatórios que precisam do aval do CMS para sua aprovação.

No citado estudo de MORITA (2002), é importante destacar, a verificação da existência de representantes de usuários que nunca foram usuários de serviços públicos de atenção primária.

Os gestores entrevistados chamam a atenção para a necessidade de capacitação dos conselheiros e queixam-se de que os prometidos cursos com esse objetivo não foram viabilizados até então. MORITA (2002) demonstrou que parcela significativa dos Membros do CMS de Botucatu julga que a Secretaria Municipal de Saúde não repassa informações sobre a pclítica de saúde, sendo isso mais intenso entre representantes de usuários. Diários oficiais, circulares e memorandos são utilizados pelos representantes institucionais, enquanto os representantes de usuários fazem uso da "cartilha do SUS" e, tanto representantes institucionais quanto representantes de usuários, afirmam que suas fontes de informação não são adequadas e suficientes.

Os Conselhos Municipais de Saúde, instituídos pelo Estado, objetivam a participação popular, entendida como força propulsora de mudanças na realidade. Porém, quando o Estado não compartilha adequadamente as informações, a observância desse preceito do SUS torna-se prejudicada. Mediante o DSC dos gestores participantes deste estudo, denota-se que a participação comunitária na gestão do SUS, nesta região, continua sendo um desafio.

Descentralização e autonomia dos municípios só é possível com controle social, caso contrário os instrumentos de regulação do Estado sobre os municípios devem prevalecer, no sentido de se evitar conseqüências altamente indesejáveis.

Continuando o estudo do processo de regionalização na perspectiva dos gestores, thes foi apresentada a seguinte pergunta:

Como tem sido o acesso das pessoas deste município aos níveis secundário e terciário da assistência? 


\section{Quadro Sintese das Idéias Centrais}

\begin{tabular}{|l|l|}
\hline A & $\begin{array}{l}\text { Alguns docentes da UNESP não entenderam que o SUS é um convênio, que } \\
\text { o SUS não está lá de graça. }\end{array}$ \\
\hline B & $\begin{array}{l}\text { As vezes a gente encontra um gargalo que, até o paciente entrar, já se foi o } \\
\text { paciente. }\end{array}$ \\
\hline C & $\begin{array}{l}\text { Demanda reprimida nas Unidades Básicas procura qualquer porta aberta } \\
\text { de Pronto Socorro. }\end{array}$ \\
\hline D & $\begin{array}{l}\text { Mesmo com o apoio da Central de Vagas há dificuldade em conseguir } \\
\text { internação. }\end{array}$ \\
\hline E & No nível secundário a demanda reprimida é visível. \\
\hline F & $\begin{array}{l}\text { As pessoas não estão ficando sem atendimento de níveis secundário e } \\
\text { terciário. }\end{array}$ \\
\hline
\end{tabular}

A - Alguns docentes da UNESP não entenderam que o SUS é um convênio, que o SUS não está lá de graça (G1, G4, G6, G10, G11).

Então, a gente pega alguns exemplos de alguns ambulatórios que às vezes não funcionam porque determinado segmento vai ter um congresso. Só que assim, não fica nada no lugar, simplesmente tem um congresso e a população é largada à margem, então não tem reposição dessas consultas, quer dizer, não existe esse tipo de preocupação, então isso ai acaba complicando realmente o atendimento.

Ainda tem departamentos dentro da Unesp que ainda têm olhar acadêmico, ele só trata da assistência no que ele tem interesse. Só que assim, as pessoas ainda não incorporaram que o SUS é um convênio e o SUS não tem que se sujeitar à área acadêmica, o SUS paga pelo seu atendimento e é um convênio. Eu não posso ficar ao bel prazer de como o departamento resolve dar continuidade na sua atenção. Então eu não posso permitir que em novembro pare o atendimento, porque os estudantes estão preocupados com a sua formatura e não vão mais atender, eu não posso ficar sujeito a um convênio SUS em que o médico vai para um congresso e desmarcon todos os seus atendimentos. Então, esse entendimento na Unesp dentro de alguns departamentos ainda não foi incorporado.

Alguns docentes não entendem que o SUS é um convênio, que o SUS não está lá de graça, ele está pagando e tudo que estiver ligado a área acadêmica, está voltado a outra fonte de financiamento que não é o SUS, a fonte de financiamento é outra para 
esse tipo de trabalho de pesquisa, de ensino. Então, as pessoas parecem que estão fazendo um favor de estar dando assistência.

\section{B - Às vezes a gente encontra um gargalo que, até o paciente entrar, já se foi o paciente (G1, G8, G10, G12).}

Eu posso falar do nivel terciário, eu acho que o Hospital das Clinicas continua com alguns defeitos meio crônicos, em relação ao número de consultas, o jeito que a população tem acesso... Eu acho que isso é uma coisa complicada.

Já aqui mesmo a gente tem pacientes que precisam ser encaminhados para fazer uma diálise no hospital da Unesp, ou mesmo, precisa fazer uma ampulação de membro devido à isquemia, pacientes diabéticos, que são mais complicados, a gente não consegue vaga. Não consegue. E são raríssimos os encaminhamentos, a não ser que tenha às vezes, algum médico de lá da Unesp que esteja dando plantão aqui, que seja amigo lá do fulano de tal e dai consegue. Eu acho que isso dai é uma grande dificuldade que nós enfrentamos aqui, pacientes acabam falecendo. Eu mesmo sou médico, perdi vários pacientes, porque a Central de Regulação não tinha vaga, não tinha vaga e o paciente vai cada vez piorando, vai piorando de um dia para o outro e acaba falecendo.

Alguns leitos, algumas dependências da Unesp, estão lotadas porque estão dando atenção a coisas que poderiam estar sendo feitas aqui em nosso município e em outros municípios da região. Eu acho que se encaminha muita gente para a UNESP, então sobrecarrega de atendimento secundário, que não precisaria ser referência da Unesp, desfalcando o terciário que é de grande importância, como a diálise, a ressonância, a ultrassonografia e outros atendimentos, a radioterapia, a própria quimioterapia, que às vezes a gente encontra um gargalo que, até o paciente entrar, já se foi o paciente. Eu acho que o nivel terciário é complicado porque não atende só os 30 municipios da região mas os 50, 60 municipios.

Então, a gente tem algumas dificuldades. Eu estou com 2 pacientes com deslocamento de retina, $90 \%$ (de possibilidade) de perder a visão, porque eles precisam fazer uma cirurgia. Nós fomos tentar ver em outros serviços, os profissionais querem nos cobrar 6 mil reais para fazer essa cirurgia. Eles, UNESP. têm o aparelho, o aparelho está quebrado, uma ponta que custa 1 to reais para 
consertar essa ponta, só que nós descobrimos que o custo beneficio não dá lacro. E ai vão deixar o aparelho quebrado. Isso é muito ruim. Eu acredito que deveria ter algumas prioridades. Analisar caso a caso e priorizar esses casos. Não adianta você encaminhar um paciente que a gente sabe que precisa de um tratamento urgente, um tratamento rápido e a Unesp, ou o NGA, marcar para 2, 3 meses. Eu acho que isso complica um pouco para nós enquanto municipio pequeno.

\section{C - Demanda reprimida nas Unidades Básicas procura qualquer porta aberta de Pronto Socorro (G2).}

O nível primário tem uma quantidade de serviço pré-fixada, que se traduz no número de consultas, que são tantas consultas por profissionais contratados. E o acesso é de demanda espontânea. Tem uma capacidade pequena de casos extras, praticamente dois, três casos extras por profissional, o que significa que tèm uma demanda reprimida muito grande e a demanda reprimida em algumas unidades é visivel, em outras unidades ela não tem visibilidade porque, por experiência anterior a pessoa compareceu ao serviço numa eventualidade, não foi atendida e ela sabe que não adianta voltar, que ela não será atendida, então ela já procura, imediatamente, qualquer porta aberta de pronto socorro da região.

\section{D - Mesmo com o apoio da Central de Vagas há dificuldade em conseguir internação (G5, G9, G12, G13, G14, G15).}

A gente tem bons diálogos, mas está dificil pela quantidade disponivel de vagas na triagem. Em outras cidades a gente tem acesso fácil de pacientes para encaminhar ao núcleo de gestão, núcleo de assistência de especialidades, mas é limitado também o numero de especialidades deles. E é uma dificuldade colocar paciente no hospital dessa cidade, por problema de vagas. A gente não sabe a situação deles e, geralmente, quando a gente precisa colocar um paciente lá, principalmente emergência, a gente tem que estar acionando a Central de Vagas, mesmo com o apoio da Central de Vagas ainda há uma dificuldade para conseguir a internação do paciente, muitas vezes ele fica horas no Pronto Socorro aguardando leito, 
aguardando vaga. Então, tem poucas vagas e eu estou aqui, colocando os pacientes em ordem de chegada para poder encaminhar e eles reclamam do prefeito que não está cumprindo, que eles buscam outros meios de ir em outros lugares, então ai que dificulta um pouco. Às vezes, o próprio pediatra (que também trabalha no município de referência) está aqui. Ele está avaliando que a criança precisa de uma internação, mas que o primeiro municipio de referência não vai ter recurso para resolver, nós não podiamos ligar para a Unesp porque tinha que ser primeiro para esse municipio. Então, como fazer? O pediatra iria deixar a criança aqui, ia até o município de referência para ligar. Então, não tinha essa compreensão.

Agora, se, por exemplo, tivesse um municipio perto de nós que tivesse todas as especialidades, não havia como ir buscar mais para frente, tudo seria solucionado ali.

\section{E - No nível secundário a demanda reprimida é visível (G2, G3, G5, G7).}

O hospital terciärio, que é único na região, está atendendo um contingente cada vez maior de pessoas. E, provavelmente, nós temos dentro do hospital, vou chutar ai, uns $20 \%$ só desses pacientes que têm mesmo a complexidade terciária. Então, o que eu tenho visto de uma maneira geral, é assim, hospitais ociosos. Eu fii num hospital no fim de semana, não tinha $10 \%$ dos leitos ocupados. Então, acho que o acesso para as afecções de caráter crônico, eu acho que o acesso é fechado é quase que restrito. É só perguntar para qualquer pessoa se ela consegue operar de varizes no SUS, hérnia, não é? Você vê, a gente não está falando ai de um enxerto aortobifemural, esse tem acesso. Esse, acho que tem um acesso até mais fácil do que as varizes. Por que às vezes interessa fazer, faz parte da especialidade, sei lá. Então, eu acho que o acesso é assim, não sei se eu estou falando a verdade, mas profissionalmente parece que o acesso ao serviço terciário para algumas coisas é mais fácil do que ao secundário. Na urgência-emergência, como é uma coisa desesperadora, esse acesso acaba sendo de uma certa maneira garantido. E a gente, aqui na nossa região, a gente não tem problemas pontuais no sentido de que o paciente morreu por falta de assistência, mesmo que seja uma assistência terciária, ai um trauma crânioencefálico, uma UTI. Mas o secundário é ruim. Alguns pacientes que precisam de 
procedimentos como, por exemplo, cirurgia cardiaca, tenho notado pelos relatos alguma dificuldade menor de acesso.

Temos o problema de que as especialidades do nivel secundário, algumas especialidades, deixa-me corrigir, porque tem muitas especialidades do nivel secundário que estão fazendo um bom atendimento e estão no limite do seu atendimento e ainda assim insuficientes. Mas, algumas especialidades atendem muito pouco, agendam muito pouco e por alguns relatos esparsos, mas que são pertinentes, a qualidade da consulta nem sempre é o que se esperaria de um atendimento mais especializado, para algumas especialidades. A pessoa diz: $O$ médico olhou para mim, colheu a minha história, nem me examinou e fez a receita. Então, se já passou por uma consulta do médico geral, ou do clínico pediatra e ginecologista, e ainda acha que precisa de um especialista, eu imagino que essa consulta com o especialista deveria ser mais acurada, com mais tempo, com um exame bem feito, tal.

O nivel secundário em Botucatu é muito pequeno e não é exatamente uma porta aberta, ela é o sistema de referência e ai a demanda reprimida é visível e pode ser traduzida pela fila de espera nas diversas especialidades.

E tem dois tipos de filas de espera, tem uma fila de espera que ela é registrada num livro, então você sabe exatamente a consulta para a especialidade $x$, o caso novo é em março de 2003 e tem outra que não segue essa metodologia, então ela agenda para o próximo mês e ela tem um dia no mês seguinte que ela agenda para o mês inteiro, então você não consegue quantificar a demanda para aquela especialidade. Ele fala assim, consulta no dia tal, e marca até o dia 31 os casos novos, depois do dia 31, para marcar caso novo, precisa retornar num determinado dia, então você não sabe o tamanho da fila. Você não sabe o tamanho da espera.

\section{F - As pessoas não estão ficando sem atendimento de níveis secundário e terciário (G10, G15, G16, G17).}

Eles têm facilidade de chegar no nível terciário, que é o HC de Botucatu, porque eles vão espontaneamente. Mas melhorou bastante agora. A Central de Vagas também está passando por uma reformulação total, nós estamos com Conselho 
Gestor, cada um dá sua opinião, então isso tem ajudado muito. Então, eu acho assim, que as pessoas não estão ficando sem esse atendimento de nivel secundário e terciário, não está ficando não, tem sido bem atendido sim.

Eu acho que está mais fácil, com exceção dessas duas especialidades que eu relatei, que são ortopedia e vascular, com os outros atendimentos eu estou satisfeito, o pessoal, o povo está satisfeito, porque quando ele não está, ele vem até mim reclamar e acho que ficou muito bom.

Tudo que a gente precisa, a gente tem procurado o máximo possivel resolver tudo aqui dentro da nossa unidade mista. Até ampliando horas de observação daqueles casos mais simples de pacientes aqui dentro, já que a gente tem médico 24 horas. E os casos que realmente precisam ir para um hospital, têm ido para o município de referência, quando precisa de uma maior complexidade eles têm encaminhado para a Unesp.

Quando eu assumi a secretaria se faziam 70 tomografias, nós ampliamos para 200. Não tenho mais demanda reprimida. Mamografia eram 60 mamografias, uma coisa absurda. Nós ampliamos para 400. Ultra-som, eu pagava um profissional num preço exorbitante para me fazer 100 ultra-sons. Eu fiz um convênio com ele assim, você vai receber a mesma coisa só que eu vou te pagar com tabela SUS. Hoje ele me faz 500 ultra-sons para ele poder ganhar o que ele ganhava antes. Então, essas coisas... eu tinha muito problema em encaminhar vascular que não tenho na rede. Então nós conversamos com os vasculares, fizemos uma tabela do SUS e um pouco da AMB, entramos num acordo, fizemos um projeto de Lei e em algumas especialidades a gente mantém esses convênios. Então, a parte secundária eu consigo resolver muito bem aqui.

Dados encontrados na pesquisa com usuários no Serviço de Urgência/Emergência e os discursos dos gestores indicam dificuldades importantes de acesso aos serviços que atendem nos níveis secundário e terciário existentes na região, levando ao aumento da demanda ao HC-FMB-UNESP.

No nível terciário, as dificuldades parecem estar ligadas ao fato desse nível de atenção à saúde estar sendo prestado por um hospital universitário. São apontados problemas como: congressos médicos, época de formatura, férias em finais de ano, 
ocasiões em que os atendimentos ficam suspensos, deixando de existir o nivel terciário em áreas médicas envolvidas com esses eventos. Além desse tipo de problema, é observado o interesse acadêmico que seleciona pacientes para o atendimento e, deste modo, alguns casos não têm acesso, enquanto outros, que poderiam ser acompanhados em UBS ou hospital secundário, têm acesso até mais facilitado por conta desse interesse acadêmico. A isto se acresce o fato do Hospital Universitário atender usuários de municípios de outras regiões, ficando com sobrecarga ainda maior. Também o fato de médicos docentes do hospital universitário ainda desconhecerem o SUS traz, como implicação, descompromissos com a prestação de assistência segundo os preceitos do SUS.

A UBS, por reprimir demanda devido ao insuficiente número de casos extras que atende, gera a busca do usuário pelo Serviço de Urgência/Emergência e este, se tiver sorte de encontrar o interesse acadêmico pelo seu caso, será atendido, acompanhado, porém, talvez nunca mais retorne a UBS.

Para consultas com especialistas, os usuários devem ser atendidos primeiramente na Triagem de Especialidades, mas as insuficientes quotas distribuídas aos municípios também apontam para a dificuldade de acesso a esse atendimento.

Quanto ao nível secundário, o acesso está praticamente fechado para o atendimento de portadores de determinadas doenças crônicas, estando até mais fácil o acesso em casos de afecções mais graves que requeiram tratamentos mais especializados e onerosos, como o exemplo citado de grande dificuldade de acesso para cirurgia de varizes, mas uma facilidade maior para cirurgias de enxerto aortobifemural.

A existência de leitos ociosos nos hospitais secundários da região tem sido explicada pelo desinteresse pelas internações pelo SUS por questões de financiamento.

As dificuldades de acesso em todos os níveis, primário, secundário e terciário na região da DIR XI, e especialmente em algumas áreas da assistência médica, mostram a fragilidade do sistema de saúde regional, dando margem ao agravamento de doenças pela impossibilidade de diagnóstico e tratamento precoces. 
É bastante promissor o fato de que alguns municipios desta região, atentos aos preceitos do SUS, estejam conseguindo melhorar a acessibilidade dos usuários aos serviços secundários, ampliando a oferta de serviços, horários de atendimento, contratando especialistas para áreas cujo acesso está mais difícil e, concomitantemente, ampliando as equipes do Programa Saúde da Família (PSF).

No entanto, é preciso intensificar o enfrentamento das questões relativas ao Hospital Universitário, objetivando sua completa inclusão no SUS; impedir o sucateamento dos hospitais secundários e adequar o nivel secundário às necessidades da população quanto à oferta de leitos e especialistas; tornar a atenção básica acessível aos usuários na maior parte do tempo, oferecendo atenção contínua e exercer a vigilância da saúde das famílias mediante equipes do PSF. É preciso estar atento ao princípio da integralidade, que garante o acesso da população a todos os niveis da atenção. Descuidar do nível secundário e terciário significará a não observância de preceitos éticos e constitucionais, fato que poderá forçar transferências de usuários para o setor privado, privatizações de serviços, e formas diferenciadas de atendimento nos hospitais universitários, mediante venda de serviços. Para os que não puderem ser transferidos, restará a cesta básica de procedimentos clínicos e de saúde pública definida pelo Banco Mundial (WORLD BANK 1999), contrariando os preceitos de universalidade, eqüidade e o princípio de justiça.

Os gestores comentam sobre a hierarquização e a regionalização da assistência nos discursos referentes à questão:

\section{Como está a hierarquização e a regionalização da assistência?}

\section{Quadro Síntese das Idéias Centrais}

\begin{tabular}{|l|l|}
\hline A & Vamos ter uma possibilidade de regionalização e hierarquização adequadas. \\
\hline B & Hoje, a regionalização funciona. \\
\hline C & Há problemas financeiros e de capacitação dos gestores. \\
\hline D & Ao entrar na UNESP o paciente é seqüestrado do nosso município. \\
\hline E & O paciente vai e volta, vai e volta, fica aquele ping-pong. \\
\hline F & $\begin{array}{l}\text { Com a NOAS, ou a gente vai ter que se organizar ou vai ter que fechar as } \\
\text { portas. }\end{array}$ \\
\hline
\end{tabular}




\section{A - Vamos ter uma possibilidade de regionalização e hicrarquização adequadas (G1, G5).}

A Central de Regulação é um mecanismo de regulação, mas é um mecanismo ao mesmo tempo de discussão de qualidade do serviço, do porquê encaminha, porquê que não encaminha.

Teremos um nivel de referência em uma unidade ou mais de uma unidade, que receba os encaminhamentos, que seria o clínico de adulto, o pediatra e o ginecologista. Então, numa primeira instância, o médico geral pode estar encaminhando para o pediatra, ou o que é uma urgência ele vai encaminhar para o pediatra sim e o pediatra vai atender, esse pediatra está numa outra unidade que nós vamos chamar de, talvez de policlínica, qualquer coisa assim, mas que é uma unidade básica ainda. O ideal é que os casos de pediatria sejam lodos selecionados, casos mais problemáticos, e que uma vez por mês o pediatra se desloque até lá, se sente com a equipe e resolva aqueles casos, junto com a equipe.

Depois, o nível secundário de assistência precisa de uma reformulação. Nós temos o ambulatório de especialidades que é o NGA, ligado ao estado, mas claramente o estado não tem interesse em continuar com a assistência, e eu acho que está correto. O estado tem outro papel, o papel da assistência eu acho que deve ser cada vez mais municipalizado, ou regionalizado pela NOAS, mas que essa regionalização seja acertada entre os municipios com interveniência da DIR, quer dizer, a DIR é importante, a DIR coordena, mas os pactos e as ações devem ser acordados entre os municipios.

Este atendimento de nível terciário é mais complexo, ele atende uma região muito maior, ele extrapola a região da DIR, mas de qualquer maneira a média complexidade nós queremos assumir, e estamos pretendendo solicitar gestão plena. Eu acho que a partir dai nós vamos ter uma possibilidade de regionalização e hierarquização mais adequada com parceria grande da Unesp. A Unesp remanejaria parte do seu Pronto Socorro para o Pronto Socorro Municipal, tornando-o mais resolutivo e o Pronto Socorro da Unesp ficando como uma retaguarda. Melhoraria até para as internações e tudo o mais, que hoje lotam os leitos da Unesp e quando se precisa de um leito para alta complexidade, ele está 
lotado com a média complexidade, prejudicando, inclusive o papel da Unesp, que esse ninguém tira dela, que é o papel terciário.

\section{B - Hoje, a regionalização funciona (G2, G7, G11, G12, G14).}

Existe essa regionalização, principalmente para pré-natal de alto risco. A faculdade de medicina, ela realmente assumiu esse papel, ela se preocupa com a mortalidade materna, com a mortalidade infantil e ela tem desenvolvido mecanismos ágeis de resposta para toda a DIR de Botucatu, principalmente, e tem oferecido suporte até para outras regiões do estado de São Paulo. Outra tentativa que eu vejo que tem sido bem sucedida é da neurologia da faculdade de medicina. Ela tem se colocado na retaguarda dos serviços de toda a região da DIR de Botucatu. E posso dizer também que a dermatologia é outra tentativa bem sucedida, que oferece suporte para toda região de Botucatu e fica preocupada quando não consegue dar vazão à demanda de solicilações.

A regionalização que está hoje, eu acho que é uma regionalização que funciona. Existem vários pontos falhos, mas eu acho que nós não precisamos nos ater só às falhas, nós temos que nos ater aos sucessos. Por exemplo, eu acho que este ano eu não tive dificuldade com uma transferência até agora. E quando eu falo transferência, não é fraturinha de braço, que não tem ortopedista para fazer alguma coisa, eu falo de um traumatismo craniano, eu falo de uma gestante de alto risco, falo de quando realmente precisa de uma intervenção. Eu acredito que pelo menos para o nosso município tem funcionado e eu não posso reclamar desse aspecto.

O paciente fica em observação aqui, no periodo que tenha que ficar, e encaminhamos aquilo que tem que encaminhar, que independe das nossas condições e estrutura fisica e a gente encaminha ou para o Hospital Regional ou para a Unesp em Botucatu. Antes, o nosso municipio não tinha muitos exames sofisticados, tipo tomografia, densitometria óssea, cateterismo, porque era mais destinado a municipios grandes, era mais dificil o encaminhamento, mas agora através da NOAS e da PPI que se está fazendo, se está facilitando esse ingresso do município pequeno a esses exames.

Eu acho que a regionalização para nós, enquanto município pequeno, é muito boa. 
Eu acho que veio para ajudar muito, tendo em vista que a nossa prefeitura e Secretaria de Saúde dos municipios pequenos não conseguem contratar todos os especialistas.

C - Há problemas financeiros e de capacitação de gestores (G3, G5, G9, G10, G11, G15, G16).

Existe uma série de normalizações ocorrendo, uma das coisas que faz com que não flua como está no papel para fluir é quando vocé não sabe quem vai pagar a conta. Porque quando você coloca no papel o vulto de tudo que você precisa, é um dinheiro absurdamente maior do que nós temos hoje sinalizado. O que está acontecendo hoje na NOAS para mim, com algumas alterações, nada mais é do que o SUDS que era o sistema único de saúde descentralizado. Funcionou na época muito bem, só que não se compara o SUS hoje com o SUDS, que com o SUDS vamos dizer, sobrava dinheiro em todas as prefeituras pequenas pelo menos. Então, as pessoas têm muito medo também de asstumirem coisas que não têm absoluta certeza que darão conta de fazer. Alguns gestores já estão extremamente conscientes do seu papel e estão avançando, estão propondo, estão provocando discussões, mas alguns ainda se mantêm como paisagem, simplesmente não é com eles a situação. Então, ainda é um momento rico de discussão, mas eu acho que a gente vai levar, ainda, algum tempo cruzando discussões com a questão financeira e com a capacitação que o gestor tem de conduzir essas coisas, porque a gente tem ainda gestores que caberiam estar realizando e não mais discursando, ou questionando. Eu acho que o questionamento é importante para o nosso crescimento, mas um questionamento de regras que já estão estabelecidas e discutidas, não cabe mais hoje uma discussão, cabe você estar avançando e não estar se acomodando, esperando ver o que vai acontecer. A nossa Santa Casa tem uma demanda muito grande, por exemplo, na maternidade, eu tenho pacientes que vêm dar a luz de parto normal, porque não tem um obstetra no municipio da parturiente. E não é um municipio de 6 mil habilantes, é um municipio de 10, 15, 20 mil habitantes. A DIR de Botucatu nos ampara muito nisso. Ela nos apóia muito nisso de criar um consórcio na área da saúde, mas ai fica dificil porque é muito fácil para o municipio comprar uma ambulância e mandar o paciente para 
frente, o dificil é você fazer um projeto de Lei passar na câmara e dizer: Olha, eu vou manter um município para poder dar essa assistência.

\section{D - Ao entrar na UNESP, o paciente é seqüestrado do nosso municipio (G2, G4, G6, G16, G17).}

A regionalização é um pouco confusa pelo seguinte, nosso município fica muito perto de Botucatu, o acesso a Botucatué muito fácil, então Botucatu, principalmente a Unesp, tem uma demanda espontânea muito grande, e que não é encaminhada por nós e nós perdemos esse contato porque cadê a regionalização disso? Nós não temos esse contato do paciente. Esse paciente foi tratado lá? Não foi? Foi como? Foi encaminhado por nós? Por que ele foi encaminhado? E normalmente a demanda é espontânea, quer dizer, ele foi espontaneamente, o acesso é muito fácil lá e se ele chega numa urgência ele é atendido mesmo e acaba ficando por lá e acabou. E a gente acaba ficando com um número muito alto de pacientes dentro do HC que a gente nem sabia que estava lá. Inclusive, até óbitos que a gente não investiga porque a gente não sabe que estão lá ou que estão em outro local.

A Unesp oferta serviços para o usuário dela, ela não oferta serviços para o usuário de referência nosso. Se nós temos uma mamografia para realizar, nós não temos mamógrafo, nós não conseguimos essa mamografia com nosso médico aqui, esse paciente vai ter que ir lá, agendar uma consulta, passar pelo ginecologista de lá, pelo mastologista e começar o processo e a mamografia vai ser realizada lá e o tratamento vai ser realizado lá. Então, o paciente só vai ter acesso a essa regionalização, a partir do momento que nós tivermos essa integração real com a Unesp. Ao entrar lá na Unesp o paciente é seqüestrado do nosso municipio. De que forma? Vamos continuar no problema da mamografia, a paciente é hipertensa, a Unesp já encaminha essa paciente para a nefrologia e começa um atendimento de nefrologia lá, sendo que poderia estar fazendo aqui. Ah, ele é diabético, encaminha para o endócrino, começa o atendimento do endócrino em vez de estar fazendo aqui. O paciente nunca sai da Unesp, ele fica lá. Então cada vez mais você vai ver ônibus e onibus indo para a Unesp. A partir do momento que a Unesp fechar essa porta, eu não sei de que forma vai ser isso porque ninguém pode negar atendimento, mas quando ela servir realmente de referência e contra-referência para aquilo que nós 
tivermos necessidade, ai isso ai vai poder começar a funcionar como um sistema único de saúde. Porque hoje o que a gente tem é o sistema único fora da Unesp é o sistema único dentro da Unesp.

Na Unesp, de um tempo para cá estão receitando medicamentos de allo custo que os municípios não têm condições de pagar e exames também, como ressonância magnética de encéfalo, que a Unesp não está fazendo e nós não temos onde fazer pelo SUS, então o municipio vai ter que arcar com esse exame. Um ou dois, ludo bem, mas se a moda pega, o município não vai ter condições, municipio pequeno não tem condições.

E existem outros que não se sentem pertencentes ao SUS. Eu poderia citar o caso da cirurgia vascular, por exemplo, que é super complicada a questão da referência, da contra-referência, da hierarquização. É uma mentalidade que tem muito ainda dentro da faculdade de medicina, que é do hospital universitário que tem que ter clientes selecionados para treinamento de alunos e residentes. E ai eles selecionam dentro da morbidade disponível aqueles casos que eles precisam no momento. Então, se querem ensinar varizes, vamos internar varizes. Se o SUS precisa de um outro tipo de cirurgia, não consegue.

Temos algumas dificuldades, principalmente com duas especialidades, que é ortopedia e vascular. Então, a gente não consegue vaga nunca, já brigamos com o pessoal, mas é falta de profissionais também. O pessoal de ortopedia do municipio de referência é um pouco complicado, tem algum problema interno lá com a Santa Casa, então a gente passa apurado aqui, porque o paciente, coitado, precisa do atendimento.

\section{E - O paciente vai e volta, vai e volta, fica aquele ping-pong (G13, G16, G17)}

Nosso municipio é um municipio que não tem renda própria, recursos próprios. $A$ gente tem uma unidade hospitalar desativada e depende muito de outras unidades para colocar os pacientes que o municipio não consegue dar assistência, e a gente encontra muita dificuldade nisso, além da distância que o municipio está de grandes centros. 
Na nossa região, tem o município de referência que também não é suficiente. $O$ paciente vai e volta, vai e volta, fica aquele pingue-pongue. Não tem especialidade, é nossa referência, mas não atende com os requisitos que a gente necessita. Aqui teve hospital e está fechado, então, por isso que complica. Eu acredito que se tivesse hospital resolveria $90 \%$ dos nossos casos.

A nossa primeira referência, seguindo a hierarquia, também não tem todos os recursos. Por exemplo, neuro não tem. E nós não podemos ligar direto para a Central de Vagas porque primeiro temos que nos comunicar com a nossa referência. E os familiares próximos de um caso de um acidente, um AVC, eles ficam contra a gente por causa dessa espera de nós termos que ficar dependendo do município de referência, eles têm consciência que tudo isso só vai demorar mais.

\section{F - Com a NOAS, ou a gente vai ter que se organizar ou vai ter que fechar as portas $(\mathrm{G4}, \mathrm{G10}, \mathrm{G11})$.}

A própria normatização em assistência hoje, ela não te dá espaço para você dizer que vai fazer, ou você faz, ou você faz, não tem outra saida mais, não tem mais aquele acordo de cavalheiros. Então, é uma situação hoje extremamente discutida. Eu acho que do jeito que a gente está indo, a NOAS que está chegando aí a qualquer momento, muitas coisas já funcionam com a NOAS, o que vai acontecer? Ou a gente vai ter que se organizar, ou a gente vai ter que fechar as portas, e mais uma vez quem que vai sofrer? Se você fechar as portas de uma loja de brinquedo, o máximo a criança vai chorar uma noite e pronto, mas se você fechar a porta para um paciente grave, você vai levar à morte esse paciente, então é dificil.

Só que a NOAS vai estar obrigando os municípios a assumir certos compromissos, que eu me preocupo muito, porque assumir no papel é uma coisa e desenvolver na prática é outra. E a NOAS está fazendo isso. Então faz uma avaliação por pessoas que estão sentadas lá no gabinete em São Paulo, no Ministério da Saúde e, de repente, acha que eu tenho condições de fazer. 
Um dos gestores entrevistados, pareceu-nos não saber o significado dos termos regionalização e hierarquização, visto que $\mathrm{cm}$ sua resposta trata da hierarquização de cargos administrativos.

Bem, nós aqui temos o prefeito, que dá a assistência tolal à saúde e dá autonomia para a gente fazer algumas coisas também, como campanhas, campanhas que a gente está dando início agora, campanha de pediculose, parasitose, são campanhas que são extra oficiais, mas a gente está atendendo também nesse sentido. A população também lá no hospital, eles são atendidos, tem diretor, tem vice-diretor, tem o responsável pelo Pronto Socorro e existem sempre as hierarquias para cada setor, a gente está procurando distribuir as tarefas para que cada pessoa fique na sua função.

Os gestores entrevistados citam algumas estratégias, que estão sendo adotadas ou pensadas, em direção à hierarquização do atendimento em níveis de complexidade crescente e à regionalização do sistema. São elas:

a) Central de Regulação Médica - que vem sendo considerada importante para o acesso de doentes em estado mais grave;

b) Estabelecimento de mais um nível de referência para as UBSs "policlínica", para um atendimento primário de casos mais problemáticos;

c) Pactuações acordadas entre os municípios, tendo a DIR um papel coordenador;

d) O município de Botucatu assumir a gestão plena do sistema municipal (GPSM) e trabalhar em parceria com a UNESP, com um Pronto Socorro Municipal mais resolutivo e o Serviço de Urgência/Emergência da UNESP mais dedicado à alta complexidade.

São estratégias que deverão desenvolver acordos políticos e instrumentos operacionais, visando à integração entre os serviços de saúde. O fato de Botucatu vir a assumir a GPSM poderá resultar em ganhos nos padrões de oferta, capacidade instalada e cobertura de serviços hospitalares e ambulatoriais, conforme apontou o estudo de VIANA et al (2002) ao analisar 523 municípios em GPSM entre 1998 e 2000. Entretanto, esses autores verificaram que tais ganhos não resultaram, 
necessariamente, em ampliação do acesso da população aos serviços de saúde e maior racionalidade sistêmica. Ou seja, a GPSM para Botucatu poderá significar melhor otimização de recursos e melhores condições administrativas, mas não será suficiente para uma melhora significativa do acesso e da eqüidade da atenção aos usuários do SUS, se não houverem concomitantes investimentos de recursos nas UBSs do municipio e medidas que viabilizem a integração dos serviços de saúde existentes no município e na região.

O hospital das Clínicas da FMB - UNESP, que deve atender a alta complexidade da região, apresenta problemas a serem enfrentados e resolvidos, objetivando a integração. Algumas áreas da atenção médica consideram o ensino e a pesquisa sua função precípua e, desta forma, vinculam a assistência a esses interesses, não à situação epidemiológica da região. Assim, selecionam os pacientes segundo os interesses do ensino, comprometendo o acesso e a eqüidade da atenção à saúde dos usuários do SUS. Quando um usuário é atendido, com grande freqüência não retorna mais ao serviço do município. O serviço de saúde do município não tem mais noticias desse usuário, nem mesmo quando ele morre.

$\mathrm{O} \mathrm{HC}-\mathrm{FMB}$ ainda traz para a região o problema relacionado aos pedidos de exames muito caros, que muitas vezes são questionados quanto à sua real necessidade, havendo, em certos casos, a suspeita de que o academicismo é que parece justificá-los. Quando o próprio $\mathrm{HC}$ não faz esses tipos de exames, por problemas técnicos relacionados aos aparelhos ou aos seus operadores ou à longa espera pela vaga para realização dos exames, entende que os municípios devem assumir os custos e os exames serem feitos em serviços privados. Para municípios pequenos, o custo elevado de certos exames pode comprometer parte importante do seu orçamento, decorrendo daí a preocupação dos gestores de que "se essa moda pega..."

O temor decorrente de incertezas relacionadas aos recursos financeiros tem dificultado as pactuações entre os municípios e conseqüentemente a organização hierarquizada e regionalizada da assistência. Alguns municípios não estão conseguindo cumprir com os acordos já efetuados. Municípios que atuam como sede de módulo assistencial, em diversas ocasiões, não estão conseguindo atender o pactuado com os seus adscritos, causando problemas de idas e vindas para os 
usuários. Por outro lado, municípios adscritos que deveriam ter, pelo menos, o médico obstetra, o clínico geral e o pediatra e não têm, sobrecarregam seus municípios de referência.

Ainda, sobre esta questão da regionalização do sistema, é importante destacar a percepção de alguns gestores que manifestaram sentirem-se pressionados a acatar normas que lhes são impostas por aqueles que atuam somente em gabinetes e não conhecem as realidades locais.

Se, por um lado, verifica-se a existência de gestores com grandes dificuldades até para a leitura das normas operacionais e, também, para o entendimento de que hierarquização da assistência não se trata de hierarquia administrativa de cargos nos serviços de saúde, apontando para a necessidade imediata de capacitação desses gestores, por outro lado, a observância da ética e da democracia na elaboração das normas operacionais é condição necessária para o seu cumprimento.

Sem dúvida, a capacitação dos gestores constitui aspecto relevante do processo de regionalização do sistema. Varias experiências de abordagens metodológicas utilizadas para a formação de gestores já foram apresentadas na literatura, como as que adotam o planejamento estratégico como referencial, as que se baseiam em estudos de casos, ou as que articulam conceitos e práticas de modo a possibilitar novas abordagens dos problemas de saúde e implementação de intervenção. Outras formas de aprendizagem alternativas, que levam em conta a disponibilidade reduzida dos gestores, mostram-se factíveis e de bom nivel (TANAKA et al. 1999; SILVA 20001).

O presente estudo identificou a necessidade de capacitação dos gestores municipais de saúde da região estudada, entendendo que isto deva merecer atenção especial no processo de implementação da assistência regionalizada e hierarquizada.

Em 2001 inicia-se o processo de organização do sistema regional, atendendo aos ditames da NOAS SUS 2001, na região de Botucatu - DIR XI, norma que foi revogada em 2002, substituída pela NOAS - SUS - 2002.

Com o intuito de conhecer a percepção que gestores municipais desta região têm sobre a NOAS, foi-lhes apresentada a seguinte questão: 


\section{O que você acha da NOAS?}

\section{Quadro Síntese das Idẻias Centrais}

\begin{tabular}{|l|l|}
\hline A & É muito bonito o que está escrito no papel, mas eu não sei se é aplicável. \\
\hline B & Ainda não conheço muito a NOAS. \\
\hline C & A NOAS veio para melhorar o sistema. \\
\hline D & A aplicação da NOAS é complicada. \\
\hline E & A NOAS ainda precisa ser discutida. \\
\hline F & Para algumas coisas a NOAS foi boa, para outras não. \\
\hline
\end{tabular}

A - É muito bonito o que está escrito no papel, mas cu não sei se é aplicável (G1, G13, G14).

Então a NOAS está sendo implantada? Eu acho que é uma coisa bonita no papel, mas na prática, está deixando muito a desejar ainda. É muita exigência, muita cobrança e a gente teve que escolher para onde a gente mandava os pacientes e até agora a gente não teve resultado nenhum. De toda essa papelada que a gente fez, a gente não teve retorno. Então, nós também estamos sem saber o que está acontecendo. A gente faz um projeto, faz um programa e na verdade lá na frente para tudo e a gente não está tendo resposta do que a gente fez.

É uma organização que, infelizmente, sai de pessoas muito superiores a nós, que não conhecem as realidades da saúde do Brasil. Então, no papel ficou linda, a NOAS está maravilhosa, vamos ver se na prática vai funcionar.

Se, por exemplo, fosse cumprida a totalidade dos $100 \%$ que está escrito de todas as ofertas que eles estão dando, seria a coisa melhor que apareceu nos últimos 20 anos, porque praticamente você tem acesso a tudo através dela. Não somente em sentido médico, mas de exames, nesse sentido de municípios, e lugares onde o paciente vai depois ser tratado e medicado.

Acho que, enquanto instrumento, ela é importante, agora, a dúvida é a questão da execução dela enquanto instrumento, a praticidade dele, vamos dizer assim. 
Eu acho a NOAS assim, ela tem uma história que já vem de NOB, que já tem exemplos anteriores, que é muito bonito o que está escrito no papel, mas eu não sei se é aplicável, eu não estou conseguindo ver isso aplicado ainda, porque cu estou achando muito dificil aplicar a NOAS. Muito dificil.

\section{B - Ainda não conheço muito a NOAS (G2, G9, G10, G15, G16).}

Eu não tenho me atualizado nas novas diretrizes do SUS, por isso, o que eu posso te dizer é alguma coisa que eu sei de vigilância epidemiológica, que hoje o recurso de vigilância epidemiológica é passado de fundo a fundo, no meu tempo não era assim, e que o municipio, em pactuando as metas, pode gastar o recurso que ele recebe dentro da vigilância da maneira como ele programar, mas eu tenho que te confessar, eu não estou a par das diretrizes mais atuais.

A NOAS, como eu assumi a coordenação há + meses agora, a secretaria há t meses, eu estou ainda assim, não bem atualizado com a NOAS. A gente tem até estudado ela, mas eu não tenho assim como dizer uma classificação da NOAS porque eu não sei se... No meu ponto de vista, não seria muito viável a NOAS, porque ela difere muitas coisas dos principios que a gente tem. Eu acho que a saúde no Brasil, hoje, está trabalhando muito em torno de normas, de leis e eu acho que está deixando $\mathrm{um}$ pouco o paciente, a qualidade, a atenção humana ao paciente. Porque nós tivemos a $N O B$ um tempo atrás e eu acho que nem a NOB completou suas diretrizes já vem a NOAS.

Ainda não conheço muito a NOAS. Eu estou mais louco, cada vez que a gente a lê. Eu acho que a NOAS ainda não está muito clara para ninguém. Eu acho que ainda a compreensão dela não está clara. 


\section{C-A NOAS veio para melhorar o sistema (G3, G5, G6, G10, G11, G12).}

Eu acho a NOAS interessante quando ela propõe uma nova pactuação e acho também interessante quando ela procura fazer com que os recursos sejam racionalizados.

Eu acho que a NOAS veio para melhorar o sistema que já está posto aí. Que não adianta nada, o municipio às vezes muito pequeno, municipios que deveriam realizar uma atenção básica boa, querendo fazer exames mais especializados, como um ultra-som. A gente vê municipios com 4, 5 mil habitantes com aparelho de ultra-som de última geração, que às vezes até a própria Unesp não tem e lá com falhas, com folgas, não têm uma população para poder referenciar. A NOAS veio para normatizar isso. Hoje, classificou alguns procedimentos em M1, M2, M3, dividiu os municípios em módulos, sede de módulos, ele quer ser plena do sistema, ou plena da atenção básica ampliada. Então, ou o municipio começa da base, dando atendimento de atenção básica primária de boa qualidade, absorvendo tudo aquilo, ou acontece desde um exame de eletrocardiograma que o municipio às vezes não tem, mas tem o ultra-som, desde um Raio Xodontológico que não tem e às vezes não tem o interesse em ter, fisioterapia e outras coisas. Então, a partir de agora, o município vai ter que assumir as ações básicas de saúde e não vai poder mais realizar, se ele quiser realizar vai ter que ser por conta própria.

Mas eu acho que no fundamental, quer dizer, os municipios que têm mais recursos eles cobrem os municipios menores nas questões de maior complexidade. Eu acho que está correta a NOAS, se a NOAS for aplicada junto com a PPI, que tem lá os valores dos procedimentos, e junto com o PDR (Plano de Desenvolvimento Regional), eu acho que a gente caminha para uma boa hierarquização. Então, a NOAS, eu acho que ela avança em relação a NOB. A NOB, ela tratava o município isoladamente, agora cla trata o município no contexto da sua região, que eu acho que está correto.

Sou um dos primeiros que querem que a NOAS seja implantada. Não estou assumindo a gestão plena de atenção básica ampliada na NOAS por conta de que somos gestão plena do sistema NOB 96. E o que a gente já recebe de PAB, eu assumindo o PAB da NOAS, não vai me interferir em nada, vai continuar do mesmo 
jeito. Estou esperando somente o sinal verde da secretaria para entrar com a documentação para a gestão plena do sistema, e vamos assumir plena do sistema, sendo sede de módulo, inclusive.

Eu acho que ela veio para ajudar nós enquanto municipios pequenos, eu acho que nós temos que assumir as nossas responsabilidades, temos que demonstrar isso, temos que assumir aquilo que nós pactuamos, temos que assumir a pactuação num todo, como eu acho que a sede de módulo tem que assumir a sua parte. Por quê? $\dot{E}$ uma cidade maior, é um centro maior, então, a partir do momento que eu fiz a pactuação, que a NOAS nos deu a oportunidade de fazer essa pactuação, eu acho que os secretários têm o direito de não aceitar e indicar outros meios da regionalização. Nós vamos saber com quem estamos pactuando, por que estamos pactuando, quem nós estamos pagando, o que nós estamos pagando. Então eu acho que vai esclarecer muito.

Eu acho que assim, se ela funcionar de fato, vai valorizar muitos municipios que como Avaré e Botucatu, arcam com outros municipios e eles vão estar recebendo agora, porque antes o que acontecia? Esses dois municipios já sustentavam outros municipios, só que não recebiam nada. A NOB fez um pacotão e falou: - Tome que está tudo embutido aí. Hoje, não. Hoje está tudo diferenciado. Os valores estão muito defasados, mas o importante da NOAS é que eles foram pré-estabelecidos, então você tem 30 ultra-sons/ano. Ótimo, dai isso foi pactuado porque a NOB não pactuou as quantidades, então o municipio falaria assim: - você tem direito a fazer essa mamografia comigo, só que ai hoje a gente conversa assim: - Você tem direito? Já venceu as suas 30 ? Você não tem mais direito.

Eu acho que é bom a gente ter norma para fazer os atendimentos, ela exige bastante dos municípios. E agora com a mudança de governo, não sei se isso vai mudar ou continuar, a gente fica numa expectativa. Mas acredito que vá ficar, porque as coisas também não podem estar mudando todo o dia, e eu acho que ela nos orienta sobre o que a gente tem que fazer. Tudo bem que tem coisas que a gente acha que não dá para fazer, mas ela vem para nos orientar. 


\section{D - A aplicação da NOAS é complicada (G3, G5, G9, G10).}

Já ouvi algumas críticas à NOAS que ela está sendo formulada mediante o número de demanda. Então é assim, a demanda histórica da região para tal afecção é $x$, vamos distribuir esse $x$ de tal maneira que o município faça, o outro encaminhe, etc e tal. A demanda histórica que nós temos é demanda histórica do que nós fazemos, não do que nós não fazemos. Nós temos duas demandas além daquela que nós fazemos, que é a demanda reprimida, que nós conhecemos ou não e aquela demanda que não áparece na estatística, porque ela não procura o serviço de saúde porque a oferta é tão dificil, que o individuo não procura. Porque você tem assim uma idéia: bom eu preciso de um posto de atendimento em tal região porque lá tem uma população que não é atendida e eu conheço essa população que é x, então a afecção tal começa a aparecer naquela população.... uma demanda de coisas que você não estava prevendo, porque essa população não tem nenhum acesso. Você nem sabe se ela é reprimida. Então acho que a NOAS precisa considerar isso um pouco mais fortemente.

Os municípios maiores que têm gestão plena, que recebiam o dinheiro para a gestão plena, têm reclamado da NOAS porque eles dizem assim: Olha, nós recebemos o dinheiro para a atenção especializada, só que este dinheiro que vem do Ministério precisa ser complementado pelo recurso municipal. Então no momento em que um procedimento de alta complexidade não é coberto pelo valor que o SUS repassa, eu preciso pegar esse valor importante e acrescentar em cima dele um tanto de dinheiro do município. Só que a hora que eu estou abrindo para o município vizinho, a NOAS diz o seguinte: Aquele dinheiro dos procedimentos complexos do municipio vizinho será repassado para o município sede, só que ele não cobre esse custo. Então, eu estou subvencionando a cidade do lado. Embora esse argumento seja verdadeiro, eu acho que o município sede, pólo, se ele tem mais recursos ele tem que atender, porque se o município é pequeno ele nunca vai ter condições de fazer um atendimento de alta complexidade. Então eu não sei como resolver.

Eu acho a NOAS complicada. Complicada no sentido da aplicação dela. Porque, por exemplo, principalmente quanto à regionalização, não ficou muito bem definida, por exemplo, no caso de internações, cada cidade, cada região vai ter um valor $x$ de 
AIH, que é Autorização de Internação Hospitalar, e ai como é que faz? Como é que eu faço com os municipes daqui que vão em demanda espontânea? Eles vão recusar lá a demanda espontânea? Porque aí eu vou ter que pagar para lá, para o HC o valor da AIH deles, que é um valor que não vem para mim, que podia ser feito aqui, mas a pessoa quer porque quer ir lá, porque tem nome, tem uma coisa, às vezes tem amigos, parentes que são médicos, são docentes e a pessoa quer ir lá, então tem essa dificuldade que eu acho. Por exemplo, se fica aqui, nós temos uma média de 250 reais por AIH, e a Unesp fica com uma média de 850 reais por AIH, como é que eu faço para pagar essa pessoa que foi por demanda espontânea? Então é bem dificil, porque eu não vou receber por isso. Mas vou ter que pagar por isso.

A NOAS exige muita coisa. Eu acho que estão tendo muitas normas seguidas umas das outras e eu acho que isso ai pode ser que venha a gerar algum empecilho no desenvolvimento, na descentralização do SUS, da saúde, porque a NOAS, para a gente olhar pelo pouco conhecimento que a gente tem dela, ela cobra muitas coisas que municipios pequenos não têm condições de arcar. Eu acho que a NOAS, por exemplo, no municipio meu mesmo, eu (prefeitura municipal) tenho um laboratório de análises clínicas para atendimento de pequenas coisas, do básico, que foi reformado totalmente há 3 meses atrás para se enquadrar nas normas da vigilância. Meu laboratório não vai poder prestar serviço para o SUS, porque eu não tenho uma unidade de retaguarda, não sou sede porque eu não tenho uma unidade hospitalar, não tenho um pronto socorro. Então, tem um laboratório totalmente equipado e o municipio vai ter que arcar com os custos, porque a NOAS não permite o municipio fazer isso. Tenho funcionários contratados, tudo, e tenho que arcar com esses custos e não tenho da onde tirar esses custos. Então acho que a NOAS deveria ser melhor estudada, revisada, porque municipios pequenos vão perecer.

\section{E - A NOAS ainda precisa ser discutida $(\mathrm{G4}, \mathrm{G10})$.}

Eu acho que para a nossa regional ainda, ela vai dar muita discussão, pelas características da nossa regional. Nós temos nossos municípios ainda muito dependentes tecnicamente e no nivel da nossa regional, muito. Eu acho que isso dificulta um pouco o avanço, a DIR tem que provocar o tempo todo essa discussão, 
sendo que a gente entende que a DIR deveria estar assessorando os municipios e os municipios deveriam estar provocando essa discussão, estarem se organizando, estarem "brigando" entre si, pelo seu pedaço, pelo seu avanço, deveriam estar discutindo nos seus Conselhos, deveriam estar discutindo nas suas câmaras municipais, com todas as outras secretarias municipais de saúde, a própria área do municipio.

A DIR nos proporcionou a oportunidade de estarmos juntos, mas nem todos foram. Então, o que aconteceu? Teve municipio que pactuou sem saber se a gente tinha ou não o serviço e agora vai ser um problema sério, porque nós falamos: Não tenho esse serviço, eu prefiro te devolver esse dinheiro. Então, fica muito dificil e houve a flexibilidade assim: Se eu conseguir me estruturar, você me devolve esse dinheiro que ai eu resolvo. Houve essa flexibilidade da DIR, na nossa regional. Quando eu pactuei, me falaram assim: Nossa, você está pactuando tudo para você? Você está jogando pouca coisa para fora! Eu falei: Olha, eu não sei se essa coisa vai dar certo ou não, então não quero perder meu dinheiro, eu quero segurar. Se não der certo, eu sei que eu vou ter que devolver, mas se eu conseguir, pelo menos, eu estou garantindo isso. Por que eu vou perder isso? Então, ai que alguns municipios que estavam jogando tudo falaram: Eu acho que é melhor fazer isso mesmo, vamos segurar para ver o que dá para acontecer. Eu acho que vai ter muito dessa prática.

\section{F - Para algumas coisas a NOAS foi boa, para outras não (G7, G8, G17).}

Eu acho que a responsabilidade é bastante. Só que a verba não vem. Eu acho que eles deveriam pensar um pouco mais que os municípios estão cada vez mais com dificuldades financeiras. O hospital mesmo, a gente está com o hospital com divida, tem divida no hospital, por causa disso. A situação do SUS... não, não... É mais responsabilidade e dinheiro que é bom, nada.

Nós tivemos que fazer um tipo de uma pactuação com Botucatu. Por quê? Ou nós éramos um hospital que a gente atendesse e procurasse ser sede nossa mesmo e ser nosso e estar tendo resolutividade aqui dentro, ou nós teríamos que estar encaminhando os pacientes a Botucatu. Aí o que acontece? Botucatu está atendendo de acordo com as possibilidades dele e ele já tem o pessoal de Botucatu para 
atender. Então, está saindo da nossa fatura um dinheiro para estar indo atender em Botucatu. E Botucatu também tem o seu limite, que tem seu pessoal e mais os pontos de referência dele. Então, eu acho assim, eu acho que tem coisas que a NOAS foi boa, mas tem outras que eu acho que mesmo os municipios não estavam ainda preparados para estarem assumindo determinadas coisas que foram colocadas. Então eu acho que em alguns pontos foi bom, em outros até pegou o município meio de calça curta mesmo.

Um grupo de gestores entende que a NOAS se apresenta, no papel, como um instrumento muito bem feito, porém consideram dificil de operá-lo. Voltam a fazer referências ao caráter impositivo de normas elaboradas por pessoas distantes das realidades locais, podendo deduzir-se que os municípios se sentem obrigados a cumprir com determinações que podem não estar em sintonia com suas condições e necessidades.

Queixam-se também do excesso de normas e portarias com as quais têm que lidar e das dificuldades para entendê-las. A afirmação de que "fica mais lonco cada vez que lê a NOAS" pode estar indicando alguma ambigüidade presente no texto da norma, identificada ou não, mas causando um certo mal-estar no leitor. Esta suposição é reforçada pela seguinte fala: "no meu ponto de vista, não seria muito viável a NOAS, porque ela difere dos principios que a gente tem", caso os princípios do SUS sejam os princípios que se tem. HORTALE (1999) explica que o termo descentralização é ambíguo pela multiplicidade de conceitos que comporta dada a heterogeneidade dos setores que a defendem.

CARVALHO (2001) ao analisar as Normas Operacionais Básicas, aponta alguns erros nos quais essas normas incorreram ao inovarem ou normatizarem além e acima da Constituição Federal e da Lei Orgânica da Saúde. Não estaria ai a causa da dificuldade de entendimento da NOAS? A regionalização e descentralização, com ampliação de responsabilidades dos municípios na gestão do sistema de saúde local, está sendo viabilizada?

Nesta região, ouve-se muito, entre gestores e outros funcionários ligados ao gerenciamento da atenção à saúde as expressões: "agora é fazer ou fazer, não há outra saida" ou "tudo isto já está dado, não se tem mais o que discutir". Assim, a já 
debilitada autonomia dos municípios fica mais enfraquecida, inclusive pela sua relação de dependência aos recursos financeiros, pois ao atrelar financiamentos à Atenção Básica Ampliada, à responsabilização de microrregiões qualificadas e à organização dos serviços de média e alta complexidade, se está usando desse instrumento para impor uma política de saúde local, ou uma reorientação de ações, que pode não ser condizente com a necessidade do município. Pesquisa do Núcleo de Estudos de Políticas Públicas da Universidade de Campinas, realizada com secretários municipais de saúde do país revelou que para $80 \%$ dos secretários de saúde municipais a implantação do Piso da Atenção Básica (PAB) reorientou as suas ações para a atenção básica (MARQUES e MENDES 2002).

Dessas pressões de financiamento podem decorrer as pactuações entre municípios sem que um conheça as reais condições do outro e de haver município cujo gestor afirma ter pactuado "tudo", não por ter condições de ofertar tudo o que constou do pacto, mas por receio de perder dinheiro. Mais adiante, poderão surgir as impossibilidades para o município arcar com as responsabilidades assumidas, os conflitos entre municípios, e os usuários sofrerão as conseqüências de mais uma experiência "mal sucedida".

Há gestores que nas entrevistas afirmaram não se sentirem preparados para cumprir algumas das determinações da NOAS, entendendo que estas os obrigam a assumir mais responsabilidades, num cenário de grandes dificuldades econômicas e de financiamento, com hospitais endividados e serviços de saúde "sucateados". Outros entendem que os municípios são tecnicamente muito dependentes da direção regional.

As origens e determinantes dessa dependência certamente reportam-se à centralização autoritária que vigorou no passado e à "municipalização tutelada" que vigora ainda nos dias atuais, não sendo, portanto, adequada a culpabilização dos municípios cuja autodeterminação encontra-se ainda reduzida.

A descentralização é um preceito do SUS, cujo objetivo é garantir maior autonomia para os municípios com relações de articulação e complementaridade entre os niveis de governo e potencialização de recursos e estratégias de atuação. 
Para isso, os municípios precisam ter liberdade para atuarem e inovarem para além das normas, tendo presente os preceitos do SUS e compromisso político com a melhoria da saúde e da qualidade de vida dos cidadãos.

Não se trata de advogar o espontaneísmo e o voluntarismo, mas de defender a elaboração de normas que ofereçam diretrizes para a operacionalização do que já está expresso na Constituição Federal e nas leis da saúde, sem necessidade da adoção de instrumentos que podem ter um caráter intimidatório. 
4.6 Conclusões dos gestores sobre a atenção à saúde prestada nos municípios da região.

Finalizando as entrevistas, foi perguntado aos gestores, com base em tudo o que havia sido dito, o que poderiam concluir sobre a assistência à saúde prestada pelo município. Foi possível observar que alguns gestores repetiram ou reforçaram idéias já mencionadas na entrevista, outros que, no início da entrevista, demonstraram o entendimento de que a assistência à saúde em seu município estava sendo prestada de modo resolutivo, atendendo aos princípios de universalidade e eqüidade, nesta questão, após as reflexões que foram feitas durante a entrevista, reformularam algumas de suas convicções. Apresentamos a seguir os seus discursos:

\section{Quadro Síntese das Idéias Centrais}

\begin{tabular}{|c|l|}
\hline A & Ás vezes falta vontade política. \\
\hline B & Certas barreiras precisam ser encaradas. \\
\hline C & $\begin{array}{l}\text { A perda de poder aquisitivo da população tem levado a perda de convênios e } \\
\text { ampliado a demanda do SUS. }\end{array}$ \\
\hline D & $\begin{array}{l}\text { Nossos gestores precisam defender uma política de saúde pública em seus } \\
\text { municípios. }\end{array}$ \\
\hline E & A Universidade tem que mudar a formação dos profissionais. \\
\hline F & Está faltando uma grande reorganização. \\
\hline G & $\begin{array}{l}\text { Dá para melhorar a saúde do município com um pouco mais de trabalho, de } \\
\text { investimento. }\end{array}$ \\
\hline H & A atenção à saúde da população tem melhorado nos últimos anos. \\
\hline I & No geral, o SUS está decadente e na área hospitalar ainda é pior. \\
\hline
\end{tabular}

A - Às vezes falta vontade política (G1, G2, G4).

Bom, a nossa região tem em torno de 507.000 habitantes, se nós compararmos nossa regional com outras no estado, nós somos o bairro de algumas, não é? Porque a população delas é bem maior. Quando a gente vê em termos de equipamentos que nós temos, eu acho que a gente tem tudo que precisa para dar certo. Eu acho que faltam poucas coisas, faltam coisas serem atualizadas, renovadas, mas para dar certo, eu acho que a gente tem tudo. 
O que eu posso dizer é que tem parles da assistência, áreas, que estão caminhando na frente, que estão tentando se enquadrar aos principios do SUS e estão progredindo. Tem algumas áreas que estão menos desenvolvidas, mas que estão tentando oferecer uma proposta concreta de assistência e existem outras que não se sentem pertencentes ao SUS. A materno-infantil, no meu entender é a que está na frente e as especialidades cirirgicas são as que se sentem menos pertencentes ao SUS.

Às vezes é falta de vontade politica mesmo. No sistema que nós temos existem pontos negativos, mas fazer um resumo geral, para o que eu tenho, eu até considero positivo. Mas eu tenho muita coisa negativa, que é o que eu não tenho e deveria ter. Quando eu falo vontade politica, você sabe que normalmente, ou, às vezes, em alguns pontos, o secretário não tem o poder de resolução geral na mão. Você entendeu? Vamos dizer, isso depende de outros setores. Então, quando eu falo falta de vontade politica é falta de vontade do prefeito mesmo de estar, vamos dizer, jogando um pouquinho, peitar algumas coisas a mais. É tipo assim, investir um pouco mais... é tirar um pouquinho de repente de obras, tirar um pouquinho para cá, vamos dar uma atenção melhor para a saúde. Agora, eu não sei, como secretário da saide, eu tenho que puxar o tapete um pouquinho para o meu lado, como eu digo para o pessoal lá embaixo. Agora, é uma dificuldade muito grande para o prefeito, vamos dizer, priorizar, o que é mais importante hoje, de repente, sei lá? Se é eu dar. um medicamento para o paciente que está doente aqui, ou se é eu dar uma cesta básica para uma familia que está passando fome?

\section{B - Certas barreiras precisam ser encaradas (G3, G10)}

Certas barreiras precisam ser frontalmente encaradas. Que a fase de negociação jä se encerrou, de você tentar chegar num consenso no sentido de quem faz, quem deixa de fazer etc. Isso está, na minha opinião, muito bem estabelecido. Também para mim está bem estabelecido porque certas coisas não funcionam. Eu acho que a gente precisa partir para uma fase executiva do processo. Olha, fazer denúncias mesmo, ao ministério público, ao CRM. Acho que os órgãos de classe ajudam muito pouco. Eles são corporativistas demais. Eles também têm uma visão muito para 
dentro da profissão e são médicos e enfermeiros. Acho que a Secretaria de Salde Estadual tem que dizer o seguinte: Por que tem um hospital credenciado pelo SUS que não tem enfermaria de pediatria? Quem permitiu esse convênio? Tem que ter ações no sentido de dizer: olha, você tem um tempo para deixar isso em ordem.

\section{C - A perda de poder aquisitivo da população tem levado a perda de convênios e ampliado a demanda do SUS (G1, G4, G11, G15)}

Hoje a saúde já se tornou mais um problema social e eu não consigo resolver esse problema social. Eu tenho gente que até o mês passado tinha convênio, hoje está desempregado. E ela não aceita o esquema de entrar em fila de madrugada, de esperar uma hora para o médico atender.

O pronto socorro, fundamentalmente, espelha muito a condição social. E a gente sabe que o poder aquisitivo, a sustentação sócio-econômica, tem influenciado demais, tem caido muito. O que significa, então, que a maioria dos pacientes que tinha emprego e não tem, também perdeu direito a determinados convênios. Os convênios existentes não dão conta de fazer as coisas em nosso lugar, porque os convênios são caros pelo recurso existente nas familias, nossos pais de familia ganham menos de 4 salários mínimos, então, a gente tem que utilizar melhor os nossos recursos, porque senão eles vão ser sempre insuficientes, mas ainda eles não são bem utilizados. Existe uma parcela significativa da população que deixou de pagar convênio e eles se socorrem ao SUS. Então, precisamos estar atentos com essas coisas, porque significa um aumento de demanda. E ai, também, eu acho que, num contexto global, os planos de saúde, safadamente, se adequaram ao novo modus operandi dos seus associados. Eu não tenho dinheiro para bancar a internação, mas eu tenho dinheiro para consulta. Mas também não tenho para os exames. Então a gente começa a ver, e nós temos isso acontecendo e temos uma resistência, tem até com a gente mesmo, uma pressão muito grande para internar pacientes oriundos de consultórios. E para a realização de certos exames, que algum médico disse que precisa fazer tal exame, mas a indicação de tal exame não é discutida, então essa é uma outra pressão que a gente tem muito grande. Alguns hospitais têm uma porta SUS que é interessante, que é a porta de consultório. Eu nunca vi porta do SUS 
passar pelo consultório do médico, porque tem a questão do cliente que tem direito à consulta, mas não tem direito à internação, ele interna pelo SUS. Eu não sei até hoje se isso é bom ou é ruim, mas gera uma demanda que acaba burlando uma fila. Então, aquele que tem o consultório, tem talvez o acesso ao SUS, aquele que não tem o consultório tem o acesso ao SUS mediante uma fila... essas coisas. Hoje em dia a saúde está muito dificil. Dificil, assim, porque as pessoas estão doentes, não sei, ou carência, entendeu? Mas, a gente nota que o aumento de procura, de médico, de consulta, está cada dia maior. Então eu acho que isso é um problema não só nosso, de todos os municípios.

\section{D - Nossos gestores precisam defender uma política de saúde pública $\mathrm{em}$ seus municipios ( G1, G4, G16).}

Eu acho que a nossa regional é uma regional técnica, prioritariamente técnica, as discussões são técnicas, não existem questões outras neste diferencial, para a nossa hierarquização, nossa equidade, existe sim, a necessidade de que os nossos gestores sejam mais politizados e que eles defendam uma politica de saúde pública nos seus municipios e que isso seja enraizado, que eles montem equipes fortalecidas, preparadas para dar continuidade. Não se pode perder essas pessoas a cada momento, tem que ser dado um jeito dessas pessoas serem mantidas, porque não tem mais história na nossa região. A cada momento se depara com gente nova, então a história da saúde pública e os programas existentes precisam ser permanentes, eles não podem ser esquecidos ao bel prazer de cada um, é preciso que isso seja melhor enraizado na região. Falta muito, falta muito. Ainda não é o meu sonho, o meu desejo. Porque eu penso assim, eu acho que não é dar remédio, encher de médico. Não é isso que eu quero, não. Eu quero que as pessoas tenham consciência de como evitar as doenças. Eu não consigo, não consigo mesmo, é muito dificil, quando você sensibiliza um grupo é muito gratificante, mas ainda falta muita coisa. 


\section{E - A Universidade tem que mudar a formação dos profissionais (G4, G5)}

Eu acho que a gente dá conta de atender, se nós otimizarmos melhor os recursos existentes, utilizarmos para situações adequadas, mas é uma discussão que precisa ser não só com os municipios, dentro do próprio $H C$, dentro da própria faculdade, porque não se pode a cada protocolo existente também pedir uma bateria de exames que já estão no prontuário do paciente, já está lá, "eu não aproveito aquilo, o meu protocolo é melhor que o seu, eu faço o meu tudo de novo". Então, é recurso sendo jogado fora, então eu acho que é uma discussão possivel, uma discussão que avança, mas ela precisa ainda ser hoje incorporada, que a nossa região é SUS, ela é SUS, não adianta a gente ficar se iludindo com outras possibilidades. Quando eu tenho uma leva de exames pedidos e o máximo que eu tenho de positivo são $30 \%$ eu estou pedindo exame para me livrar de um paciente, e não para acolher e atender melhor esse paciente. Mas a gente percebe também que os órgãos formadores não conhecem a realidade onde eles estão sendo formados, eles não conhecem os municípios, eles não conhecem a rede básica, não conhecem os problemas de saúde pública, eles não têm idéia de gerenciamento, eles não têm idéia de quanto custa o serviço de sáide, então a gente ainda tem que avançar muito nisso. Eu acho que a universidade tem que sair de onde ela está, ou cla vai para a realidade local, ou ela não vai mudar a forma de formar profissionais. Se ela formar só para especialidade, a gente vai continuar investindo em tratamento, a gente não vai fazer o que é nossa obrigação, que é a saúde pública, que é a área de prevenção. Isso eu não tenho dúvida.

\section{F - Está faltando uma grande reorganização (G9, G10, G12)}

Acho que o atendimento é bom, mas a população está se virando. Ela encontra dificuldade num lugar, ela vai para o outro lugar. Às vezes, essas dificuldades são até insolúveis, quer dizer, um dos argumentos para ir para o Pronto Socorro é que lá é mais rápido, eu acho que a unidade não pode ser mais rápida, ela pode ser mais rápida naquele atendimento, mas a unidade faz atendimentos agendados, que não podem ser feitos em 5 minutos. Se ela for para o Pronto Socorro, é alendida em 20 minutos, meia hora no Pronto Socorro Municipal, mas a qualidade, o objetivo do 
pronto socorro é tolalmente outro. Então, eu acho que está faltando uma grande reorganização.

Eu acho que é dificil de trabalhar, porque a gente tem que fazer a saúde preventiva e curativa ao mesmo tempo. Eu acho que quando tinha a Santa Casa era bem mais fácil da gente trabalhar. A gente fazia as consultas agendadas pelas especialidades e hoje não. A oposição, que sempre foi oposição, ela hoje usa um meio de comunicação muito forte que é um rádio, que tem uma audiência assim, quase 100\% e que o tempo inteiro joga a população contra alguns serviços.

Se a gente fosse mais racional, mais integrado e hierarquizado e tal eu acho que poderia ser muito melhor.

G - Dá para melhorar a saúde do município com um pouco mais de trabalho, de investimento (G4, G7, G13, G15)

Então, ainda tem muita falha. Funcionário público, eu sou funcionária pública, é um funcionário dificil, é um funcionário que a sensação é que é assim, a gente bate o cartão para entrar e bate o cartão para sair.

Eu concluo que a saúde ainda está irregular. Há pontos bons, há pontos críticos, eu acho que ainda dá para melhorar mais a saúde do municipio com um pouco mais de trabalho, um pouco mais de investimento. Quando se fala em investimento vem assim o financeiro, não é? Acho que o financeiro também, mas investimento em pessoal, no conhecimento do pessoal. Então a gente encontra diversas dificuldades, principalmente na área de recursos humanos. Pessoas que não se adaptam às novas metodologias, ficam paradas e eu acho que isso dificulta a melhoria, acho que é preciso investir um pouco nessas coisas e pessoas, trabalhar um pouco mais com elas e investir em mais profissionais qualificados também.

Aquelas pessoas que se propuseram trabalhar para o público, que se consideram funcionárias públicas, que são funcionárias do povo, elas vão fazer, aquelas que não têm essa vocação, você pode pagar o salário que for, pode falar o que for, ensinar o que for, ela não vai se dedicar, então nós temos muitas pessoas assim, infelizmente eu tenho que falar isso. Então eu acho que faltaria um pouco, além de quantidade nos recursos humanos, a qualidade desse pessoal. 
Eu acho que dentro dos recursos que a gente tem, a gente está tentando o máximo possivel atender todos os princípios do SUS, e principalmente o da humanização que é importante, mas eu acho que a gente gostaria de ter mais recursos para depender menos dos outros municipios, inclusive da própria Unesp, no caso da Triagem.

O nosso grande sonho era ver as nossas crianças nascendo aqui. Eu sou nascida aqui todos os nossos prefeitos têm como uma grande frustração, que não tem ninguém natural deste município, todos são de Lençóis, ou de Botucatu, de São Manoel, porque nós não temos maternidade, apesar de nós termos um prédio lindo, até com equipamentos para a maternidade, dois centros cirúrgicos. Mas não temos recursos para equipar, não temos recursos para tocar, nós trouxemos até o pessoal da Casa do Parto de São Paulo para eles verem a unidade, ver o que a gente poderia estar fazendo nesse sentido, mas eles também não aconselharam, porque seria muito oneroso para o municipio.

\section{H - A atenção à saủde da população tem melhorado nos últimos anos (G6, G11, G12, G13, G14, G17).}

Há um tempo atrás ai, a saúde deste municipio era motivo até de gozação, motivo de vergonha, de não pagamento de funcionários, de não pagamento de plantões médicos e só se preocupar em ter atendimento médico até 9, 10 horas da manhã. Os profissionais contratados não eram registrados, não tinham a segurança de que poderiam continuar trabalhando. E isso tudo foi sanado. A gente implantou alguns serviços novos, a própria farmácia. Eu acho que nós melhoramos sensivelmente o modelo e a nossa atenção à saúde da nossa população. Tanto é, que dentro das pesquisas que a gente faz junto à população, a gente tem uns resultados muito favoráveis. Muito há por se fazer ainda, mas muito depende de dinheiro, e o dinheiro hoje é pouco, ele já foi melhor, ele já melhorou, mas ainda é pouco. A gente depende de um processo contínuo avançando. Iniciaram nesta administração muitas mudanças, mas já o modelo da administração passada veio com o PSF, ele só está melhorando e vai continuar.

Eu acho que com o PSF, a gente está melhorando, porque aí essas visitas estão indo na casa, estão vendo os pacientes, eu acho que está sendo um bom programa. Vai 
ser muito bom a hora que estiver bem implantado, que estiver bem, trabalhando, funcionando bem, vai ser ótimo.

Estou há um ano e dez meses no cargo, eu acho que nós avançamos alguns pontos, mas acho que também precisamos avançar mais. Um ponto é o encaminhamento, eu acho que nós estamos trabalhando para acabar até com o encaminhamento. Acho que isso é impossivel, mas tentando trazer mais especialista para o municipio, tentando trazer um anestesista para podermos fazer algumas cirurgias aqui no município, tentando, através da regionalização, montar um consórcio entre os municipios para a gente contratar alguns especialistas juntos. Acho que isso nós devemos tentar.

Quando eu assumi existia um início de um atendimento com a atenção básica. Eu acredito que nessa gestão nós conseguimos melhorar colocando pediatra, colocando ginecologista. Pretendemos melhorar ainda mais trazendo outras especialidades, para poder fixar o paciente no nosso município, porque eu entendo que é mil vezes melhor trazer o profissional até aqui e atender os pacientes aqui, do que eu ter que transportá-los. Tem o risco de vida no transporte, de estar levando... É dificil atender todo mundo satisfatoriamente, porque às vezes são muitas pessoas, você tem que colocar dentro de um veiculo que vai meio apertado e eu acho que a tendencia é melhorar e, conversando com os outros secretários dos municipios vizinhos, pretendemos fazer um consórcio intermunicipal.

As vezes me encontro sozinho na estrada e tenho que ir tocando para a frente. Contudo, eu acho que houve uma grande melhora, com o pouco que temos aqui nós conseguimos atender a maioria da gente, eu não tenho podido equipar regularmente isso, não temos tudo o que gostariamos, porque o município também não comporta fazermos tudo isso, mas na medida do possivel acredito que estamos dando ao paciente tudo o que podemos conseguir para melhorar a saúde. Eu tenho, inclusive, um quadro que está lá dentro, vou mostrar depois para você, onde eu tenho uma relação de tudo o que foi feito aqui, por exemplo, atendimentos médicos por médicos, por especialidades, programas e tudo o que a DIR de Botucatu solicita. 


\section{I - No geral, o SUS está decadente e na área hospitalar ainda é pior (G8).}

Eu acho que, no geral o SUS está decadente. O que a grente recebe do SUS e o que é obrigação, principalmente na área hospitalar, eu acho que é pior ainda. Eu já cheguei ao ponto de falar assim: Será que é vantagem você ter um hospital no municipio? Agora mesmo, eles exigiram 4 enfermeiras padrões para o hospital, como que o municipio vai arcar com 4 enfermeiras padrões no hospital, ainda o hospital não é do município, não é municipalizado, ele trabalha com recursos próprios, é a própria população que tem que manter. E não tem recursos mesmo, quem está ajudando mais é o prefeito, está mandando verba para cá, está mandando medicamentos, parte de pronto socorro, todo o medicamento é a própria prefeitura, filme de Raio $X$. Não fosse isso o hospital estaria fechado.

Quanto ao SUS o que está no papel é muito lindo. É muito lindo o que está no papel. A idéia é maravilhosa. Só que o funcionamento é que está precário.

Os discursos dos gestores revelam, em primeiro lugar, um não saber o quê fazer com os recursos que dispõem. Isto parece ser devido ao restrito espaço de governabilidade desses gestores.

Também são apontadas distorções no sistema de atendimento e citada a questão da porta de entrada do hospital universitário, em algumas situações, ser a porta do consultório médico particular. Fato que sugere a falta de mecanismos reguladores da fila de atendimento. Cabe aqui refletir sobre a inconveniência do hospital universitário em impedir o livre acesso do paciente, tendo em vista o princípio da universalidade. Por outro lado, é injusto que esse paciente, oriundo do consultório particular, passe à frente de qualquer outro, apenas por utilizar-se dessa via. Não seria mais aceitável e justo instituir-se um agendamento direto no ambulatório de especialidades, via carta de encaminhamento feita por médicos das UBSs ou de quaisquer outros serviços públicos ou privados? Que a ordem de chegada fosse seguida, com exceções baseadas em critérios bem definidos e justos, fundamentados no princípio da eqüidade, tendo claro que o setor privado não deve se beneficiar lucrativamente do serviço público, mas manter seu papel complementar? Em geral, as distorções são apontadas mas os verdadeiros responsáveis por elas não. 
Essa retórica sobre a entrada de pacientes via consultórios médicos particulares, é mais uma, dentre tantas, que tem sido usada na argumentação dos que defendem uma outra porta de entrada no hospital público para o atendimento de pacientes conveniados. A propósito, o HC - FMB já abriu essa porta para o atendimento de conveniados com o IAMSPE.

A percepção dos gestores é a de que está ocorrendo um aumento da demanda de pacientes aos serviços públicos, motivada pela falta de recursos da população para a busca de atendimento no setor privado. Essa demanda, segundo os gestores, não está sendo atendida como deveria, no que se refere à qualidade da atenção. Disto decorrem as dificuldades para se dar conta de uma demanda grande e mais debilitada, pelas condições de vida que ela padece. Isto os tem levado a refletir e a buscar alternativas para a atenção básica à saúde, ligadas à prevenção de doenças, entendendo que estas ações parecem ser mais apropriadas, mas ainda encontram muitas dificuldades para formulação de propostas sob essa perspectiva.

Gestores de municípios menores da região concordam que a atenção básica à saúde tem melhorado nos últimos anos e acreditam que a realização de consórcios intermunicipais viabilizaria uma atenção mais eficiente e eficaz.

Em visitas aos municípios da região foi observada a existência, em municípios pequenos, de hospitais e laboratórios desativados e prédios construidos que nunca foram equipados para seu funcionamento.

É certo que investimentos em diversas instituições hospitalares da região se fazem necessários e isto seria muito benéfico para os usuários. Porém, em alguns municípios, a relação custo/benefício não recomendaria investimento algum. Há municípios cuja demanda de exames laboratoriais é tão pequena que a abertura de determinados kits traria importantes prejuizos, não comportando, deste modo, um laboratório de análises clínicas do próprio município, inclusive porque no município vizinho, que é maior em termos populacionais, tem laboratório que pode arcar com exames da microrregião. O mesmo ocorre com alguns hospitais que foram construidos e permaneceram fechados. São heranças de governos anteriores que, por razões eleitoreiras, construiram esses prédios.

Isto que os gestores concluem, reflete suas percepções quanto às necessidades dos municípios a serem atendidas pelos diversos níveis de governo, municipal, 
estadual e federal, e suas expectativas de melhorias na atenção básica, mediante um processo de regionalização que promova a organização do sistema, respeitando a autonomia dos municípios. 
4.7 Sugestões dos gestores para fortalecer e ampliar as responsabilidades dos municípios na atenção básica de saúde.

Buscando conhecer, junto aos gestores, como eles vêem a possibilidade de fortalecer e ampliar as responsabilidades dos municípios na atenção básica, formulamos a seguinte questão:

O que poderia ser feito para fortalecer e ampliar as responsabilidades dos municípios na atenção básica?

\section{Quadro Síntese das Idéias Centrais}

\begin{tabular}{|l|l|}
\hline A & Há necessidade de cobranças aos municipios e aplicação de punições. \\
\hline B & $\begin{array}{l}\text { Temos que trabalhar com afinco e entender que o trabalho maior tem que } \\
\text { ser na atenção básica. }\end{array}$ \\
\hline C & $\begin{array}{l}\text { Temos que abandonar o que estamos fazendo e desenvolver novas } \\
\text { tecnologias. }\end{array}$ \\
\hline D & Os municípios precisam de mais recursos. \\
\hline E & O município precisa reforçar o controle social. \\
\hline F & Há necessidade de indicadores que avaliem a qualidade \\
\hline G & É preciso conscientização das autoridades. \\
\hline H É preciso uma parceria entre os municípios e a descentralização dos \\
profissionais da UNESP.
\end{tabular}

A - Há necessidade de cobranças aos municípios e aplicação de punições (G1, G6, G10).

E eu acho uma coisa importante, também, a própria questão do atendimento dentro da Unesp, do Hospital das Clínicas aqui da Unesp. Ele mesmo dar um retorno aos municipios do que está sendo atendido, inclusive aquelas patologias que, em tese, deveriam ser atendidas ao nível de Unidades Básicas de Saúde. E aí cobrar uma posição do gestor. De por que não está sendo atendido, mais no sentido inclusive de melhorar a assistência. Porque, muitas vezes, o paciente é encaminhado para a UNESP para uma consulta, por exemplo, por um problema pulmonar, mas na realidade o problema não é pulmonar. O problema é que ele não tem nem o RaioX para fazer o diagnóstico lá. Será que não é melhor discutir por que não tem o RaioX 
do que encaminhar o paciente para fazer o diagnóstico na UNESP? Então alguma coisa assim.

Também tinha que ter penalização. A partir do momento que você fala: Olha, você vai perder o seu dinheiro, porque lodo mundo morre de medo de perder dinheiro. A gente quando vai nas reuniões dos 30 municipios na DIR, quando falam assim: $O$ município que em 3 meses consecutivos e não apresentar o relatório perde verba, todo mundo fica apavorado. Então, realmente, eu acho que você tem que entrar com uma penalização, tanto monetária, judiciária, não sei, mas as pessoas têm que acordar para isso. Eu tenho um item em anditoria que estava em vermelho, minha mortalidade infantil, eu fiquei doente com isso, principalmente por ser mortalidade infantil. Eu fiz um levantamento, até para provar que o meu municipio é referência de 16 municipios, então o que vai acontecer? Eu vou ter mortalidade infantil de outros municipios. Tudo bem, isso não conta? Vai ter que contar, porque é alla, mas eu também pago o preço de outros municipios que saíram com mortalidade infantil maravilhosa. É lógico, veio morrer no meu município. Fica dificil isso.

E o Tribunal de Contas dando em cima disso, o próprio Ministério dando em cima disso, cobrando o gasto em saúde e não comprando ambulância para levar para a Unesp, e não comprando ônibus para levar para a Unesp, e asfaltando, e não investindo em outras coisas, na contratação de profissional, na construção de unidades e na mudança do modelo.

\section{B - Temos que trabalhar com afinco e entender que o trabalho maior tem que ser na atenção básica (G2, G3, G4, G6, G12, G17).}

Eu acho que tem que ter uma melhoria na qualidade do serviço, para as pessoas acreditarem no serviço e procurarem o serviço, porque senão também não adianta nada elas serem conscientes do problema, mas não terem o serviço para procurar a prevenção.

Em primeiro lugar, que é uma coisa que a gente vai começar a fazer agora, a gente acredita que as pessoas têm que ter consciência do que é que está acontecendo e porque elas podem ficar doentes, então a gente vai começar a mexer no meio ambiente. E com isso, a gente vai tentar conseguir a atenção dos municipes no 
sentido de prevenir algumas coisas, prevenir, por exemplo, doenças oriundas do meio ambiente, para eles também começarem a prevenir outras doenças, seriam as coisas básicas da hipertensão, do diabetes.

Eu hoje tenho uma população de 21 mil habitantes, eu estou fazendo só no Centro de Saúde, uma média de 42 mil consultas/ano. É um número muito grande. Por quê? A população é uma população carente, o nível cultural é baixo, é uma população que trabalha na lavoura, uma população que está aí com pouca instrução ainda, então eles estão procurando o posto de saúde para a atenção básica, um número muito alto de consultas, então, eu acho que para haver uma melhora nisso, eu acho que primeiro de tudo teria que haver uma melhora por parte da educação, tendo em vista que a educação seria o primeiro passo.

A cada momento você está investindo recursos no tratamento, então se nós não trabalharmos com muito afinco e entendermos que o nosso trabalho maior tem que ser na atenção básica, criando programas de saúde da família, criando programas de agentes comunitários, mesmo o modelo existente que está dado, se ele for todo movido por uma humanização desse atendimento, por um acolhimento melhor da população, o restante eu acho que a gente tem tudo para dar certo.

Talvez o PSF, talvez um posto de saúde bem localizado, bem equacionado, resolva 90\%, 80\%. Então eu acho que é uma questão que passa assim, por uma filosofia de atendimento. Eu espero que os prefeitos, os secretários de saúde de outras cidades implantem o PSF para poder rever esse modelo que está ai há 50, 60 anos, carcumido e sem resolutividade. Nós sabemos que já não deu certo e não vai dar certo porque só se trata da doença, não se investiga o nexo causal daquela doença. A atenção básica, ela é complicada. Do jeito que ela está estruturada é meio como enxugar gelo. Porque é uma coisa que não tem fim. As pessoas procuram auxilio médico para todas as questões da vida. Elas tentam resolver de maneira que envolva, em determinado momento, o médico. Aí, o que eu imagino, é que a gente deveria equacionar a atenção básica por setores, desenvolvendo tecnologias para atendimento em grupo. Muitas das questões que hoje a gente aborda de maneira individual, a gente deveria fazer um diagnóstico de situação e o acompanhamento seria tipo atendimento em grupo. 


\section{C - Temos que abandonar o que estamos fazendo e desenvolver novas tecnologias (G2, G4, G16).}

Então eu tenho que tratar o meu serviço como uma empresa mesmo, e não mais como um cabide de empregos ou um bico ou qualquer coisa que seja além da minha casa. Eu não posso tratar o meu trabalho como se fosse uma extensão da minha casa, também, eu tenho que prioritariamente estar ali a serviço público. Eacho que isso é uma retomada de coisas que as pessoas perderam a noção. As pessoas acham que o horário de trabalho delas tem que ser de acordo com o horário da casa delas. Eu não posso tratar um municipio que a grande maioria da população trabalha em atividade rural ou trabalha numa fábrica e que o seu horário de trabalho é contínuo e achar que das 8 às 17 h eu resolvi o problema do municipio.

E a gente deveria ter uma forma de devolver para a população alguma segurança para que ela mesma se responsabilizasse por algumas patologias que são muito simples e que a medicina tem pouco a oferecer. Eu digo, por exemplo, resfriado comm. A pessoa deu dois espirros, se ela tiver chance, ela vai procurar uma consulta médica, para saber se é um resfriado ou o que é. Isso é uma sobrecarga muito grande para os serviços de saúde. A gente não dá conta, ou a gente oferece alguma coisa que não satisfaz o paciente, que é o que tem acontecido no momento, porque a gente faz as consultas muito rápidas, de 15 minutos, 10 minutos, com a porta aberta e atende um grande número de pacientes e aquele paciente não fica satisfeito e passa para um outro serviço, ele fica tentando compor o atendimento, através de várias consultas médicas, e nesse atendimento ele passa, basicamente, pelo médico. É isso que eu penso, que a gente tem que pensar, abandonar o que a gente está fazendo e pensar em desenvolver novas tecnologias.

Então, primeiro, conscientização, segundo, capacilação de profissionais desde a recepção pelos auxiliares, pelos médicos. Eu tenho recebido muitos convites de cursos, de congressos, enfim, de eventos para melhorar e capacitar os médicos, como é que se fala? Reciclar, a palavra reciclagem a gente lembra de lixo, mas não $\dot{e}$. É reciclar mesmo o médico, mas eles nunca vão, porque eles estão sempre ocupados em outros lugares. Ah, eu amanhã não posso ir porque eu atendo lá, hoje eu não posso dispensá-lo porque senão ele vai fazer falta aqui. Então isso dai eu 
acho que faz falta, conscientização e capacitação para melhorar o atendimento na atenção básica.

D - Os municípios precisam de mais recursos (G3, G7, G8, G9, G11, G14, G15, G17).

A NOAS está nos obrigando a assumir algumas responsabilidades, mas será que nós temos condições de assumir essa responsabilidade?

Seria necessário que nos fosse enviado mais recursos, para que a gente pudesse equipar melhor o municipio. Hoje nós temos dificuldade até de aumentar o número de especialistas por falta de verba, enquanto que está preconizado na lei que é necessário que o municipio tem que participar com 15\%, nós estamos entrando com 19\%, mesmo assim é insuficiente, porque o que a gente tem recebido é muito pouco. Se eu juntar todas as verbas que o município recebe, não ultrapassa 13 mil reais. E a gente gasta em torno de 50, com transporte, com medicamento, com folha de pagamento e isso está saindo do município. Não sobra para ampliar profissionais e recursos na ajuda de diagnósticos e equipamentos.

Eu acho que se tivesse um pouco mais de investimentos na área da saúde com visão à atenção ao paciente, por exemplo, mais profissionais que nós não temos condições de ter. Existe uma queixa dos municípios muito grande com relação a financiamento. Alguns municipios estão assim com 19, 20... nós temos municipios aqui da região com mais de $20 \%$ de comprometimento da sua verba, do seu orçamento, enquanto nós temos municípios com menos que 10\%. Então eu acho que o município que quiser mesmo fazer parte de uma regionalização de uma municipalização, ele precisa reforçar a base. Mas não tem muito por onde assumir mais responsabilidade, porque a gente já está abraçando tanta coisa... Também seria ideal que cada município sede tivesse o apoio e contasse com uma série de especialidades e equipamentos que pudessem solucionar de forma rápida e fácil, o atendimento dos municipios dependentes dele. 


\section{E - O município precisa reforçar o controle social (G3).}

O municipio precisa reforçar o controle social, não deixar na mão dos dirigentes da saúde as decisões de saúde, porque se você for colocar estatisticamente o que o município precisa de atenção à saúde, ele não precisa de hospital terciário.

\section{F - Há necessidade de indicadores que avaliem a qualidade (G5).}

Cada municipio é classificado como se fosse um semáforo: verde, amarelo ou vermelho. Se está verde, então está tudo bem. Então, baseado nisso, os municípios podem executar algumas ações. O problema é que não há nesses indicadores, por exemplo, e eu acho que é muito dificil de fazer isso, um indicador que avalie qualidade da consulta médica, ou qualidade do atendimento de enfermagem. Eu acho que tem que se tentar alguns indicadores que consigam inferir, como eu disse, essa qualidade dos processos e procedimentos, mas a grande quantidade de indicadores é sobre resultados. Ai você pode saber: Caiu ou não caiu a mortalidade infantil? Conseguiu diagnosticar os casos de tuberculose, ou não? Conseguiu acompanhar esses casos? Curou dentro do periodo? Então, são avaliadores de resultado, que en última instância, se o resultado está bom, significa que os procedimentos devem estar bons, mas nem sempre.

\section{G - É preciso conscientização das autoridades (G11, G13).}

A conscientização das autoridades é muito importante, porque o costume é empurrar com a barriga. Eu até falei numa reunião da CIR, o seguinte: que talvez, não façam isso por querer fazer. Fazem por ignorância. Por quê? Por não conhecerem o que é o atendimento, qual é a nossa responsabilidade por atender o paciente na atenção básica. Então, muitas vezes, não se pode contratar o profissional, muitas vezes não se tem, à disposição, um veículo para ir fazer uma visita domiciliar, muitas vezes não se tem funcionários capacitados para fazer, então acho que primeiro, a conscientização das autoridades sobre qual é o nosso papel, nossa responsabilidade, do prefeito e dos vereadores porque eles têm que fiscalizar isso. A maioria dos 
prefeitos acha assim: Nós temos ambulancia para levar, leva para Cerqueira, leva para Avaré, quando a gente poderia fazer o atendimento aqui, desde que eles nos dêem condições para isso.

\section{$H$ - É preciso uma parceria entre os municípios e a descentralização dos profissionais da UNESP (G11, G17).}

Nós deveriamos nos unir e ver o que nós poderiamos estar, de uma forma mais rápida, agilizando, para que os pacientes tivessem os encaminhamentos mais rápidos, menos morosos, com exames menos demorados, exames que inclusive são solicitados e acabam não fazendo.

Acho que tem muita coisa para melhorar ainda que depende de uma parceria melhor com os outros municípios, que cada um tenha, por exemplo, uma especialidade e a gente faça esse vai e vem. Agora, eu acho que o que poderiamos melhorar com relação à atenção à saúde básica e que parece que já foi até alvo de reivindicação, seria descentralização dos profissionais da Unesp aos nossos municipios. Por que não trazer novos conhecimentos para cá? Por que não para outros municipios que são próximos? Eu acho que a Unesp sendo uma universidade estadual deve partir do estado estar trazendo esses profissionais para nós também. Não só em nivel de pronto socorro, em nivel de saúde básica.

De acordo com os entrevistados, o fortalecimento das responsabilidades dos municípios em relação à atenção básica tem várias frentes de enfrentamento. Porém, os recursos financeiros para a assistência e as mudanças na filosofia de atendimento, citadas pelos gestores municipais, parece terem sido colocados como fundamentais, donde derivariam todas as demais alterações no sistema de saúde regional.

A falta de recursos para a saúde no país é notória, principalmente, pelo escasso financiamento do setor e pelas alocações indevidas e ilegais.

No ano de 2002, o valor total referente às AlHs, na DIR XI foi de R\$ 20691575,22 . Deste total, 58,8\% foi para o HC - FMB, que realizou 13768 internações pelo SUS $(32,7 \%$ do total das internações da região). Nos hospitais dos 
demais municípios da região foram autorizadas 28276 internações $(67,3 \%$ do total de internações) e estes receberam $41,2 \%$ do valor total das AIHs da DIR XI. Isto porque o valor médio das $\mathrm{AIHs}$ do $\mathrm{HC}-\mathrm{FMB}$, no ano de 2002 foi de $\mathrm{R} \$ 868,52$. Nos demais hospitais da região o valor médio das AIH'S variou entre R\$200,00 e R\$ 350,00, excetuando-se o Hospital Psiquiátrico, cujo valor médio das AIHs foi de R\$ 616,93, explicado pela presença de moradores no hospital.

As internações no hospital universitário são, portanto, de elevado custo, justificado especialmente pelos procedimentos de alta complexidade que realiza. Porém, quando se sabe que parcela importante poderia ter sua internação em hospitais secundários da região, bastando alguns investimentos em reformas, equipamentos e pessoal, a relação custo/benefício poderia ser melhorada para os usuários e para o sistema. Deste modo, a discussão do financiamento vai além das questões referentes ao seu montante.

Segundo MENDES et al. (2001), melhorar o montante de recursos é fundamental, mas não garante a solução dos problemas de financiamento, pois o uso racional na gestão desses recursos é também importante.

Apesar das dificuldades de arrecadação, especialmente dos municípios menores, vários municípios alegam aplicar em saúde mais de $15 \%$ do seu orçamento, chegando um dos gestores a afirmar que este valor é de $25 \%$. Mas, mesmo assim, os municípios têm grande dependência dos recursos transferidos. $O$ valor repassado ao Fundo Municipal de Saúde de $\mathrm{R} \$ 10,50$ per capita anual para a assistência básica ampliada e de R \$0,50 per capita para o Programa Saúde da Família (PSF) indica que o gasto em saúde nesse nível de atenção é irrisório e que a atenção básica só tem merecido prioridade nos discursos. De acordo com LAURELL (1997), os países latino-americanos não dispõem de recursos ilimitados, mas o problema principal não é sua escassez e sim sua distribuição, havendo evidências de que muitos países poderiam garantir serviços integrais de saúde para toda a população se isso fosse prioridade social. No Brasil, verifica-se que a saúde não tem sido bem situada na escala de prioridades do Estado, além disso, a maior proporção de recursos financeiros é destinada à assistência hospitalar e aos procedimentos de alta complexidade. 
A autonomia dos gestores, referida nos discursos do coletivo destes, é considerada restrita, como também é limitada a dos Conselhos Municipais de Saúde para a administração dos recursos financeiros, destacando-se aqui um recorte da fala de um gestor: “a maioria dos prefeitos acha assim: Nós temos as ambulâncias para levar, leva para Cerqueira, leva para Avaré, quando a gente poderia fazer o atendimento aqui, desde que eles nos dessem condições para isso." Esta frase é sugestiva de uma submissão dos gestores à autoridade do prefeito municipal $\mathrm{cm}$ questões particulares do gerenciamento do sistema de saúde local. Daí a importância de um controle social rigoroso sobre o sistema de saúde municipal.

Os recursos transferidos para o Fundo Municipal de Saúde são administrados pelo Secretário ou gestor municipal e fiscalizados pelo Conselho Municipal de Saúde. Porém, estes podem ser, em maior ou menor grau, vulneráveis às ingerências. Assim, faz-se necessário o fortalecimento da autonomia dos Conselhos e dos gestores, tarefa não muito fácil, porque o modo como estes têm sido escolhidos para ocuparem esses cargos, os tornam suscetíveis às cooptações. Por esta razão, foi dito por gestores que o fortalecimento dos municípios para a atenção à saúde requer ainda um trabalho de conscientização dos prefeitos.

Quanto às necessidades de mudanças na filosofia de atendimento das UBSs, foram listados pelos gestores os seguintes aspectos que, na opinião deles, devem ser contemplados:

- melhoria do acolhimento dos usuários, da qualidade do atendimento e do relacionamento interpessoal profissional/usuário;

- adequação dos horários das UBSs às possibilidades de comparecimento dos usuários;

- utilização de metodologias de atendimento que se mostrem mais eficientes e eficazes, tendo sido citado o atendimento em grupo para situações específicas;

- ampliação do conceito de atenção básica, incluindo-se nela uma série de exames necessários ao diagnóstico e adoção de mecanismos de interconsulta com especialistas realizadas nas unidades básicas; 
- desenvolvimento de técnicas e instrumentos de avaliação da qualidade dos processos envolvidos na prestação de assistência, visto só serem feitas avaliações de resultados;

- desenvolvimento de atividades de capacitação dos profissionais;

- busca de integração dos serviços com a Universidade.

Os entrevistados ainda citaram as seguintes necessidades de mudanças na filosofia de atenção à saúde;

- Desenvolvimento do Programa Saúde da família;

- Desenvolvimento de atividades de promoção da saúde.

Quanto ao PSF, para algumas autoridades da saúde, ele representa o novo modelo assistencial do SUS, para outras, uma estratégia de reorientação dos modelos. Porém, segundo PAIM (2001) "para que o PSF não fique confinado no 'SUS para os pobres' e na 'atenção primitiva da saúde' faz-se necessário produzir cunhas no nível secundário e pontes com o nivel terciário da atenção" (p.145).

A retórica do PSF e o seu incentivo financeiro, apesar de exíguo, parece desencadear uma obstinação nos gestores para a sua implantação. Não há dúvida de que o PSF pode propiciar maior aproximação e vínculos com a população e contribuir para uma reorganização adequada da atenção básica. Porém, é ingênuo acreditar que o PSF vai resolver todas as questões ligadas à saúde e aos seus determinantes. De acordo com MERHY (2001), "uma das conseqüências é que a própria força que o PSF possa ter fica perdida ao ambicionar tanta intenção" (p.149).

Entende-se que a implantação do PSF deva ser vista como uma tecnologia que buscará uma interação social entre trabalhadores e maior autonomia dos agentes, visando a uma atenção integral. Deste modo, tem grande importância a formação e capacitação sistemática e constante dos profissionais envolvidos com o PSF, pelas características desse trabalho prestado em equipe, cujo objeto é a família e o seu entorno, onde são realizadas intervenções baseadas em conhecimentos interdisciplinares e nos determinantes do processo saúde-doença (CAMPOS e BELISARIO 2001, ALMEIDA e MISHIMA 2001). 
Conforme relato de gestores, cursos de capacitação ou "reciclagens" de profissionais têm sido inviabilizados por diversos fatores, dentre estes, a impossibilidade dos profissionais para freqüentarem esses cursos que esporadicamente são oferecidos.

Por outro lado, a formação dos profissionais de saúde continua centrada na assistência individual e hospitalar. Recentemente foi instituído o Programa Nacional de Incentivo a Mudanças Curriculares nos Cursos de Medicina - PROMED Portaria Interministerial de 26 de março de 2002 (BRASIL 2002).

Para viabilizar essas mudanças, o programa investiu 8 milhões de reais e selecionou escolas médicas para, mediante apresentação de projetos, receberem os recursos, com a recomendação de que a instituição inserida no SUS proceda a mudanças pedagógicas com ênfase na medicina preventiva, valorize a humanização do atendimento, incentive o ingresso de futuros médicos em ações de atenção básica e promova a abertura dos serviços universitários à demanda do SUS.

A Faculdade de Medicina de Botucatu foi uma das instituições de ensino selecionadas. Com isso, estão sendo desenvolvidas discussões em direção às mudanças curriculares, seguindo as diretrizes do PROMED: estabelecimento de parcerias com hospitais secundários, atuação dos alunos nas UBSs nas áreas de Obstetrícia, Pediatria e Geriatria e no primeiro ano do curso de medicina os estudantes já começarão a desenvolver atividades na atenção básica. Essa proposta foi concebida mediante parceria entre a Secretaria Municipal de Saúde e a UNESP.

Também neste ano de 2003 teve início, na FMB - UNESP, o programa de residência em PSF para médicos e enfermeiros.

Acredita-se que essas parcerias entre instituições formadoras e os serviços seja um bom começo do processo de mudanças que são necessárias na atenção básica.

Por fim, o outro aspecto citado pelos entrevistados, relacionado às mudanças na filosofia de atenção à saúde foi o desenvolvimento de atividades de promoção da saúde.

Segundo LEFÈVRE (2002) esse modo de entender e praticar a saúde propõe que além dos cuidados de prevenção, diagnóstico e tratamento das doenças, sejam elas afastadas dos individuos e erradicadas do meio ambiente e das cidades. Para essa 
tarefa, além dos técnicos, o conjunto da sociedade deve ser envolvido, com o fortalecimento e a capacitação da cidadania. Trata-se de uma nova visão, que busca estratégias eficientes e eficazes de organização da atenção à saúde, com vistas a ações de impacto sobre condições de vida, trabalho, lazer, estilos de vida das pessoas e dos grupos sociais.

Alguns municípios da região estão tentando ações intersetoriais de promoção da saúde, voltadas para formas de prevenção de riscos e proteção da saúde, porém, são iniciativas ainda bastante tímidas.

No entanto, é promissor o fato de que os gestores, ao problematizarem o modelo de saúde vigente, seus custos, complexidade do seu gerenciamento e sua baixa resolutividade, vejam no modelo de promoção da saúde uma saída possível para a crise do setor. 

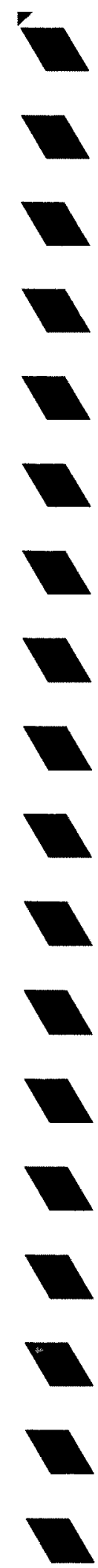

Considerações : Finais.

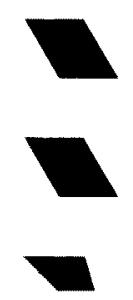




\section{Considerações finais}

Neste estudo foram identificadas, como características gerais da clientela que demanda ao Serviço de Urgência/Emergência do hospital universitário, referência terciária da região da DIR XI, o baixo nível de escolaridade, sua vinculação ao trabalho assalariado de baixo poder aquisitivo e sua dependência do Sistema Único de Saúde.

Os vínculos dessa clientela com os serviços públicos de saúde dos municípios onde reside são mais fortes entre as mulheres e os menores de 15 anos.

A procura do Serviço de Urgência/Emergência do hospital universitário, segundo doentes, foi motivada pela confiança que depositam na instituição e nesse tipo de atendimento e pela falta de condições do município em proporcionar a assistência desejada. Entretanto, ao redor de 50\% dos doentes entrevistados no Serviço de Urgência/Emergência apresentaram problemas de saúde que, segundo os médicos que os atenderam, poderiam ser resolvidos em Unidades Básicas de Saúde ou em serviços secundários existentes no próprio município de origem do doente, ou em municípios mais próximos, sem necessidade de atendimento no serviço de urgência do HC - FMB - UNESP. Gestores entrevistados também referiram que cerca de metade dos doentes que procuraram o hospital universitário poderia ter seus problemas de saúde sanados no próprio município.

De acordo com usuários e gestores, a realidade e a prática da atenção básica nos municípios da região não está adequada às necessidades dos cidadãos, havendo incompatibilidades entre horários de funcionamento das UBSs e disponibilidades dos usuários, decorrentes dos seus horários de trabalho, além da falta de recursos humanos e materiais para o atendimento. Pelos depoimentos dos gestores, foi possivel identificar problemas relativos à organização dos serviços, cuja oferta insuficiente sugere um baixo potencial de cobertura. $O$ modelo de atenção vigente está centrado no atendimento de doentes que, em sua maioria, demandam espontaneamente aos serviços da região.

Razões econômicas, situação do município e confiança no hospital universitário foram explicadas pelos usuários para a procura espontânea dos serviços da UNESP. Observam-se, deste modo, dificuldades e deficiências no acesso, 
particularmente no acesso funcional e resolutivo à atenção básica dos sistemas municipais na região.

Além das dificuldades da atenção clínica, os municípios ressentem-se de dificuldades para realização de diversos exames complementares, em especial, Raios-X, Ultra-sonografia, Eletrocardiograma e Mamografia e da falta de médicos especialistas, principalmente, ortopedistas, cirurgiões vasculares, anestesistas e psiquiatras. Foram mencionadas pelos gestores algumas iniciativas de articulação entre municípios para contratação de profissionais e/ou compra de determinados equipamentos. Essas parcerias ou consórcios, visando à otimização de recursos, ainda precisam ser mais estimuladas na região.

Há importante desarticulação entre os níveis de atenção primária, secundária e terciária, com evidente deficiência do nível secundário. Os 16 hospitais para atendimento em nível secundário existentes na região da DIR XI e os dois ambulatórios para atendimento de especialidades - Núcleo de Gestão Assistencial (NGA) - não foram apontados pelos usuários e gestores como constituintes importantes do sistema de saúde. Por isso, via de regra, eles são ignorados pelos médicos das UBSs e pelos médicos do Serviço de Urgência/Emergência do hospital universitário quando da necessidade de encaminhamentos de doentes, sob a alegação de que esses serviços não funcionam, dada a precariedade de seus recursos. Mesmo assim, verificou-se que os hospitais secundários foram procurados por 73 pacientes antes de buscarem o atendimento médico no Serviço de Urgência/Emergência do hospital universitário, com a informação complementar, de pacientes entrevistados, de ocorrência de mau atendimento, não resolução do problema e sugestão do próprio serviço para procura da UNESP devido à falta de médicos e materiais para o atendimento. Esses dados indicam a baixa resolutividade dos serviços secundários, mau acolhimento, além da sua escassez. Os ambulatórios dos NGA não têm conseguido absorver toda a demanda para consultas médicas especializadas, como também não têm condições para realizar muitos dos procedimentos que decorrem dos diagnósticos feitos nas consultas. No processo de regionalização, é importante que se leve em conta a necessidade de aprimoramento das relações e de integração dos serviços municipais e estaduais, locais e regionais existentes, de modo a que se comprometam com a integralidade da atenção e com a resolutividade. 
O HC - FMB é apontado como inibidor do desenvolvimento dos demais serviços da região e, especialmente da cidade de Botucatu, por estar, há mais de 30 anos, com suas portas abertas, atuando de modo independente, recebendo e absorvendo pacientes provenientes dos municípios de Botucatu e região, sem preocupações com a contra-referência, comportando-se, muitas vezes, como não pertencente ao SUS, selecionando pacientes segundo determinados interesses acadêmicos, suspendendo atendimentos em periodos de férias, congressos e finais de ano. Por atender do básico ao terciário, isto gerou, segundo gestores entrevistados, uma acomodação dos demais serviços de saúde e também a sobrecarga do HC FMB, especialmente do Serviço de Urgência/Emergência. Porém, é reconhecida a importância desta instituição universitária para toda a região, a qual, na atenção primária, através do Centro de Saúde Escola e Centro de Saúde da Vila Ferroviária e na atenção secundária e terciária através do Hospital das Clínicas com seus Ambulatórios, Enfermarias e Pronto Socorro, tem contribuido significativamente com a assistência à saúde da população. Destaca-se, ainda, seu papel na formação de profissionais de saúde da região, dos quais, grande parte teve sua formação na Faculdade de Medicina de Botucatu e no desenvolvimento de estudos e pesquisas de interesse para a região, intensificado nos últimos anos com os cursos de pósgraduação, especialmente com a pós-graduação em Saúde Coletiva.

Quanto à Triagem de Especialidades do HC - FMB, o sistema de quotas estabelecido aos municípios, a partir de critérios baseados em série histórica de atendimentos realizados em épocas anteriores em que além de uma demanda reprimida conhecida, havia a não conhecida, propiciou uma oferta de quotas insuficiente. Outro aspecto levantado foi a sua função mediadora entre os serviços de saúde da região e o Ambulatório de Especialidades do HC - FMB, selecionando pacientes encaminhados pelos municípios para o atendimento e seguimento no Ambulatório, de acordo com critérios que nem sempre atendem às necessidades dos doentes, mas aos interesses de ensino e pesquisa. Os serviços de saúde, que já fazem uma triagem para encaminhamento dos doentes, poderiam ter quotas para os ambulatórios e, deste modo, os doentes seriam encaminhados diretamente para lá sem a intermediação da Triagem. Porém, alguns entrevistados apontam resistências entre docentes da FMB- UNESP quanto a essa medida. 
A Central de Regulação Médica, em Botucatu, tem contribuído para melhorar a integração dos serviços de saúde e introduzir mecanismos de referência e contrareferência, mas enfrenta dificuldades para realizar procedimentos mais ágeis de alocação de pacientes, devidas às deficiências dos serviços secundários e sobrecarga do nível terciário na região. Com isso, os usuários são levados, em grande parte, a procurar espontaneamente os serviços de urgência/emergência, sem o conhecimento da Central de Regulação Médica, ou mesmo são orientados, por alguns serviços de saúde, para assim procederem. Há municípios que, segundo gestores entrevistados, "burlam" acordos estabelecidos e/ou informações, com o objetivo de conseguir uma vaga para seu usuário no Hospital Universitário, fato que tem desencadeado tensões e conflitos com a Central de Regulação Médica.

A maioria dos doentes chega ao HC - FMB - UNESP em veículos próprios. Os doentes que chegam em veículos dos municípios, ônibus ou peruas relatam que, em geral, estes não apresentam condições adequadas para transporte de doentes. Essas pessoas devem comparecer ao serviço de saúde do seu município já na madrugada, para reserva de seus lugares na condução. Na UNESP, aguardam pela consulta médica durante horas ou até mesmo durante o dia todo, sem acomodações adequadas, comendo e dormindo no chão ou gramados existentes ao redor dos locais de atendimento. As causas primeiras dessa situação têm a ver com deficiências do nível primário quanto a sua oferta e resolutividade e com questões de compromisso político-social por parte das prefeituras municipais.

$\mathrm{O}$ acolhimento e a qualidade da atenção ao usuário do SUS, em todos os níveis de assistência, foram apontados como estando ainda deficitários.

Persiste nos municípios uma prática em saúde derivada de um conceito limitado de atenção básica, segundo o qual as intervenções são feitas, em geral, sobre os efeitos da doença, predominando a assistência médica curativa, evidentemente importante e necessária, mas ainda limitada, parcial e pouco resolutiva. Assim, no processo de regionalização é importante que a atenção básica seja entendida em sua abrangência como enfoque da atenção integral, cujo objetivo é a produção social da saúde. Deste modo, as articulações e pactuações entre serviços e municípios devem ser feitas, com participação da comunidade, desde a identificação do processo saúde- 
doença e análise dos seus determinantes até o estabelecimento dos mecanismos de intervenção e dos métodos de controle e avaliação.

Apesar dos entraves, os municípios estão procurando se equipar para oferecerem serviços de atenção básica ampliada e, deste modo, se inserirem no sistema de saúde regional. Integrando o sistema, os municípios são solicitados a fazerem pactuações entre si, porém, esse procedimento é visto com certo receio pelos gestores municipais pela insegurança econômica que persiste em seus municipios. As normas operacionais e portarias ministeriais são vistas por gestores como de dificil entendimento e estes se sentem despreparados para dar conta de todas as determinações. A NOAS, elaborada com o objetivo de reorganizar o acesso da população em todos os níveis de atenção à saúde, traz algumas ambigüidades que geram dificuldades conceituais e operacionais. Assim, ela é entendida pelos gestores apenas como normatizadora e racionalizadora de recursos escassos. A ênfase que a NOAS dá ao elenco de procedimentos pré-estabelecidos, organizados por níveis de complexidade, para que os municípios atendam a tais requisitos como condição para se habilitarem em Gestão Plena da Atenção Básica Ampliada e, deste modo, integrarem o sistema regional, choca-se com o conceito de atenção básica, a qual se realiza a partir da análise da situação local e do maior aporte de ações que o município possa oferecer. Alguns gestores consideram que a NOAS 2002 é uma imposição, porque não observa a autonomia dos municípios.

A percepção que se tem das entrevistas com gestores é a de um processo de regionalização tutelado e autoritário, sem o financiamento necessário para o seu desenvolvimento.

Por outro lado, foi também percebida a preocupação dos gestores com a atenção integral aos munícipes, visando a assegurar o acesso universal aos diversos níveis de assistência à saúde, fato que sugere uma visão política de saúde pública baseada em políticas sociais universais, diferentemente das propostas neoliberalizantes que apregoam a focalização de programas sociais.

Os gestores apontaram necessidades de alterações na sistemática de atendimento das Unidades Básicas, objetivando melhor acolhimento dos usuários, bem como, avanços em direção à melhoria da qualidade do cuidado à saúde. Revelaram, ainda, interesse por mudanças na filosofia da atenção à saúde, com o 
entendimento de que o modelo de promoção da saúde poderá trazer resultados mais satisfatórios para toda a população.

A implantação dos Programas de Saúde da Família e de Agentes Comunitários de Saúde, o aumento dessas equipes, o empenho dos gestores municipais para efetuarem pactuações de interesse dos usuários e dos municípios envolvidos, a determinação da Central de Regulação Médica em garantir o acesso dos doentes aos recursos médicos de que necessitam e a problematização quanto ao modelo de atenção à saúde vigente, compõem um cenário de perspectivas muito promissoras para a região da DIR XI com a superação dos atuais entraves.

As distorções que estão ocorrendo no sistema de saúde regional e nos sistemas locais, a tipologia dos serviços e as deficiências da atenção básica provocam um movimento de demanda dos usuários em sentido inverso ao da hierarquização dos níveis de atenção.

O processo de regionalização da assistência à saúde, então, enfrenta muitas barreiras, tais como: oferta insuficiente de serviços, baixo potencial de cobertura da rede básica, fragmentação da atenção em diversos serviços que atuam sob diferentes lógicas, desarticulação entre serviços da rede básica e serviços de média e alta complexidade, falta de mecanismos eficientes de supervisão com vistas à melhoria da qualidade do atendimento, participação da comunidade bastante tímida e Conselhos Municipais de Saúde ainda despreparados para o cumprimento de suas funções, embora como já referido, haja um processo de discussão e de adoção de medidas no sentido de resolução desses problemas.

Assim, há necessidade de reforçar/potencializar esses esforços e medidas envolvendo a organização dos sistemas locais e regional, mediante articulação entre todos os envolvidos - serviços estaduais, municipais e universidade, objetivando a organização hierarquizada da rede de serviços de saúde, com maior autonomia e responsabilidade sanitária dos municípios; o efetivo exercício de uma atenção básica; o fortalecimento dos vínculos entre usuários e Unidades Básicas de Saúde, procurando assegurar a ampliação da cobertura e melhoria do acesso funcional e resolutivo, mediante melhor oferta de serviços, em quantidade e qualidade, e, por conseguinte, melhor acolhimento dos usuários e o desenvolvimento de um sistema integrado que objetive a produção social da saúde. 
As estratégias para operacionalizar essas ações pressupõem o envolvimento dos vários atores, dentre os quais a Universidade. O compromisso ético da Universidade é com a população onde está inserida, produzindo conhecimento de forma crítica e competente em benefício da comunidade. Assim, deve participar ativamente de todas as etapas da organização local e regional da atenção à saúde, articulada com os demais atores, desenvolvendo o ensino e a prestação de serviços à comunidade alimentados pela pesquisa e, deste modo, legitimando o conhecimento e se retro-alimentando permanentemente. Nesse sentido, seria oportuna uma revisão do papel do $\mathrm{HC}$ - FMB no sistema local e regional de saúde. 

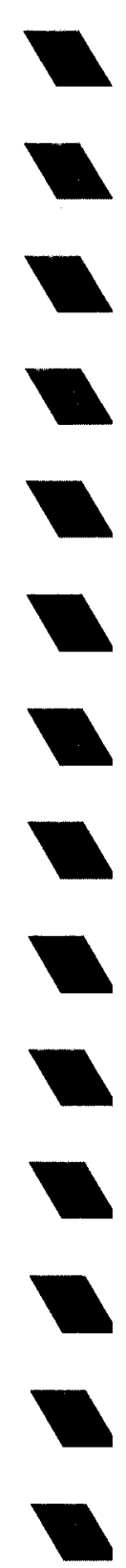

Referências

Bibliográficas

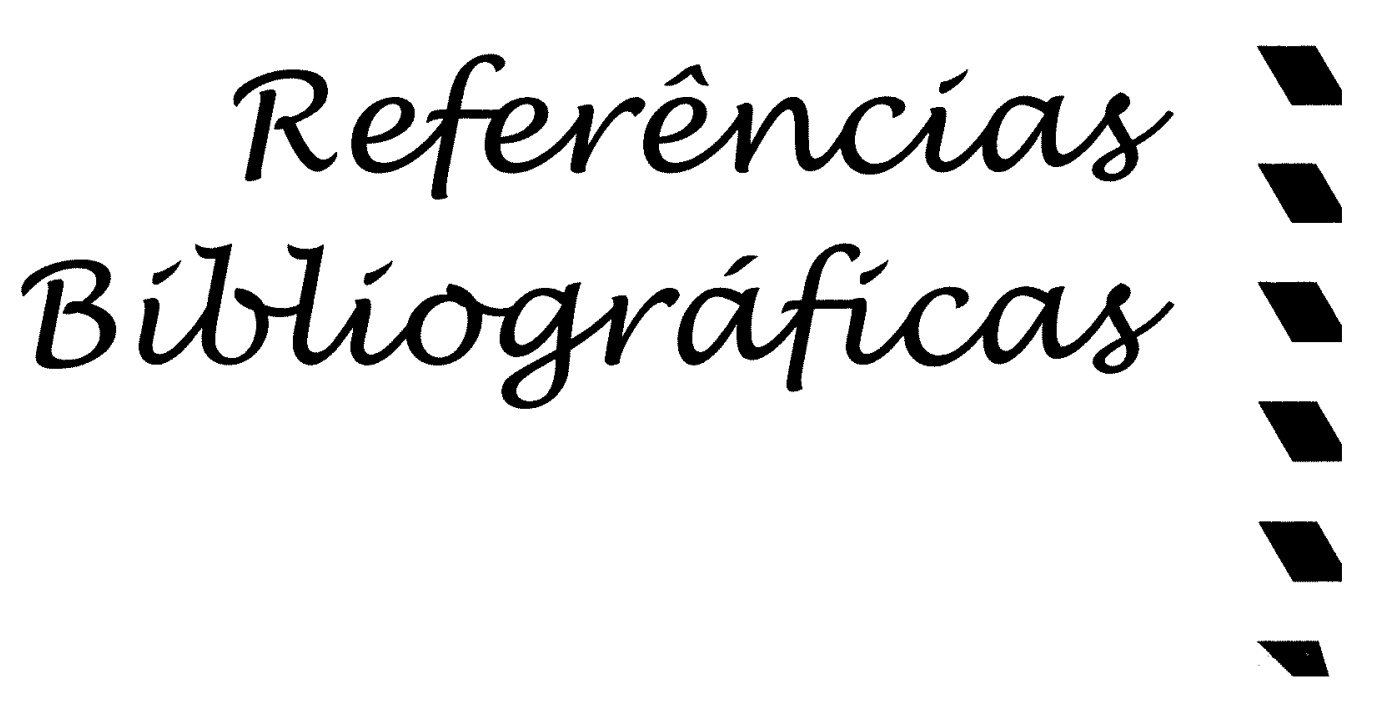




\section{Referências Bibliográficas}

Akerman M. Nadanovsky P. Avaliação dos serviços de saúde - avaliar o quê? Cad Saúde Pública 1992; 8: 361-365.

Almeida $\mathrm{CP}$, Mishima SM. O desafio do trabalho em equipe na atenção à saúde da família: construindo "novas autonomias" no trabalho. Interface 2001; 9:150- 53.

Almeida ES. Contribuição à implantação do SUS: estudo do processo com a estratégia norma operacional básica 01/93. São Paulo; 1995. p.22-44. [Tese LivreDocência - Faculdade de Saúde Pública, Universidade de São Paulo].

Almeida ES, Zioni F, Chioro A. Políticas públicas e organização do sistema de saúde: antecedentes, reforma sanitária e o SUS. In: Westphal MF, Almeida ES. Organizadores. Gestão de Serviços de Saúde: Descentralização/ Municipalização do SUS. São Paulo: Edusp; 2001. p.13-50.

Almeida ES, Castro CGJ, Lisboa CA. Distritos sanitários: concepção e organização. [Online] São Paulo, 1998. Disponível em <www.bireme.br/bsv/sp/ $\mathrm{P} / \mathrm{pdf} / \mathrm{saudcid} /$ Volume01.pdf $>$ [16 maio 2003].

Barrenechea JJ, Trujillo Uribe E. Salud para todos en el año 2000. Implicaciones para la planificación y administración de los sistemas de salud. Medellín (Colombia): Editorial Universidad de Antioquia; 1987. p.74-86.

Boltanski L. As classes sociais e o corpo. Rio de Janeiro: Graal; 1984.

Brasil. Constituição da República Federativa do Brasil. São Paulo: IMESP; 1988.

Brasil. Ministério da Saúde. Lei Orgânica da Saúde. 2. ed. Brasília: Așsessoria de Comunicação Social; 1991.

Brasil. Ministério da Saúde. Norma Operacional Básica 01/93. Brasilia:[ NOB/SUS 01/93.1993]. 
Brasil. Ministério da Saúde. Fiocruz. História das Conferências Nacionais de Saúde. Rio de Janeiro, 1998. Disponível em: <http://wwww.fiocruz.br/ contexto8html> [20 dez1998].

Brasil. Ministério da Saúde. Portaria 824 de 24 de Junho de 1999. Normas de atividade médica em nível pré-hospitalar. [Online] Brasilia, 1999. Disponivel em <http:/www.saude.gov.br/Portarias/1999/b\%20824\%20APROVA20TEX\%20DE\%2 ONORMATIZACÃO\%20IRGÊNCIA\%20EMERGÊNCIA.rtf > [16 fev 2003].

Brasil. Relatório da $11^{\text {a }}$ Conferência Nacional de Saúde. [Online] Brasília, 2000. Disponivel em <http://www.datasus.gov.br/cns/11Conferencia/relatorio/ CENARIO. htm $>$ [21 maio 2003].

Brasil. Ministério da Saúde. Secretaria de Gestão de Investimentos. O cartão nacional de saúde: Instrumento para um novo modelo de atenção. Rev Saúde Pública 2000; 34: 561-564.

Brasil. Ministério da Saúde. Portaria $\mathrm{n}^{\circ} 544$, de 11 de abril de 2001. Aprova as recomendações para orientar os convênios de investimentos ao processo de regionalização da assistência à saúde. [Online] Brasília, 2001. Disponivel em: <http://www.saude.gov.br/portarias/2001/h544 Regionalização da Assist.A saúde Anexo1-PT544.rtf> [12 nov. 2001].

Brasil. Ministério da Saúde. Portaria 373 de 28 de Fevereiro de 2002. Norma Operacional da Assistência a Saúde NOAS-SUS 02/2002. [Online] Brasilia, 2002. Disponível em: <http://www.saude.gov.br/sus/PORTARIAS/Port2002/Gm/GM373.htm $>$ [28 mar 2002].

Brasil. Ministério da Saúde. Secretaria de Políticas de Saúde. Uma nova escola médica para um novo sistema de saúde: Saúde e Educação lançam programa para mudar o currículo de medicina. Rev Saúde Pública 2002; 36: 375-378.

Caldas Júnior AL. A crise nos hospitais universitários: estratégias de privatização. Caminhos 1999; 18: 95-108. 
Campos FE, Belisário AS. O programa saúde da família e os desafios para a formação profissional e a educação continuada. Interface 2001; 9:133-142.

Campos GWS, Chakour M, Santos RC. Análise crítica sobre especialidades médicas e estratégias para integrá-las ao Sistema Único de Saúde (SUS). Cad Saúde Pública $1997 ; 13: 141-144$.

Capote Mir R Sistemas locales de salud: organización, regionalización, princípios generales. In: Paganini JM, Capote Mir R editores. Los Sistemas Locales de Salud. Conceptos - Métodos - Experiências. Washington, D.C.: OPAS/OMS; 1990. (Pub. Cientifica $N^{\circ}$ 519) p.117-135.

Carvalho G. A inconstitucional administração pós-constitucional do SUS através de normas operacionais. Ciênc saúde coletiva 2001; 6: 435 - 444.

Cohn A, Elias PEM. Eqüidade e reformas na saúde nos anos 90. Cad Saúde Pública $2002 ; 18: 173-180$.

CONCLA - Comissão Nacional de Classificação. [Online] Brasilia, IBGE, 2002. Disponível em: <http://www.ibge.gov.br/concla/concla.shtm> [03 abr 2002].

Conselho Regional de Medicina do Estado de São Paulo. Lei amplia direitos do paciente. CREMESP, São Paulo, 1999 mai; n. 141: 8.

Cortes SMV. Conselhos municipais de saúde: a possibilidade dos usuários participarem e os determinantes da participação.Ciênc Saúde Coletiva 1998; 3:5-17.

Dallari SG. Descentralização versus municipalização. Saúde em debate 1992; $35: 39-42$.

Dallari SG, Adorno RCF, Faria MM, Shuqair NSMSAQ, Trewikowski S. O direito à saúde na visão de um Conselho Municipal de Saúde. Cad Saúde Pública 1996: 12:531-540.

Demo P. Avaliação Qualitativa. São Paulo: Cortez; 1999.

Foucault M. Microfísica do poder.Rio de Janeiro: Graal; 1979. 
Gattinara BC, Ibache J, Puente C, Giaconi J, Caprara A. Percepción de la comunidad acerca de la calidad de los servicios de salud públicos en los distritos Norte e Ichilo, Bolivia. Cad Saúde Pública 1995; 11: 425-438.

Gauderer EC. Os direitos do paciente: um manual de sobrevivência. 3.ed. Rio de Janeiro: Record; 1991.

Gomes R, Mendonça EA, Pontes ML. As representações sociais e a experiência da doença. Cad Saúde Pública 2002; 5: 1207-1214.

Hortale VA. A descentralização e a autonomia na perspectiva das organizações. Saúde em Debate 1999; 23: 20-29.

Junqueira LAP. Descentralização e mudança nas organizações públicas de saúde. Cad FUNDAP 1997; 21: 137-55.

Lambrew JM. Dianosing disparities in health insurance for women: a prescription for change, 2001 [Online] Disponível em: <http://www.cmwf.org/ programs/ insurance/lambrew_disparities_493.pdf.> [16 fev 2003].

Laurell A. La globalizacion y las politicas de salud. In: Anais do Congresso Brasileiro de Saúde Coletiva, Congresso Paulista de Saúde Pública; 1997. Águas de Lindóia, Brasil. Águas de Lindóia; 1997. p.25-41.

Lefèvre F, Lefèvre AMC, Teixeira JJV. O discurso do Sujeito Coletivo: uma nova abordagem metodológica em pesquisa qualitativa. Caxias do Sul: EDUCS; 2000 .

Lefèvre F. Promoção de saúde: um novo modo de entender e praticar saúde. São Paulo, 2002. [Apostila da Disciplina: Saúde Pública: Campo de conhecimento e aplicações - Faculdade de Saúde Pública da USP].

Marques RM, Mendes A. A política de incentivos do Ministério da Saúde para a atenção básica: uma ameaça à autonomia dos gestores municipais e ao princípio da integralidade? Cad Saúde Pública 2002; 18 (supl): 163-171. 
Massé R. Culture et Santé Publique. Montreal: Gaetan Morin Éditeur; 1995.

Mendes A, Carvalho G, Castro PC, Santos SBS. Gestão administrativa e financeira na área da saúde. In: Westphal MF, Almeida E., organizadores. Gestão de serviços de saúde. São Paulo: Edusp; 2001.p.181-204.

Mendes EV. Os grandes dilemas do SUS. Tomo II. Salvador: Casa da qualidade; 2001.

Mendes HWB. Políticas de saúde e observância de princípios éticos. In: Programas e Resumos da I Bienal de Enfermagem de Botucatu; 1999; Botucatu, Brasil. Botucatu: Faculdade de Medicina - UNESP; 1999. p.23.

Mendes HWB, Caldas Júnior AL Prática profissional e ética no contexto das políticas de saúde. Rev Latino-am Enfermagem 2001; 9: 20-26.

Mendoza-Sassi R, Béria JU. Utilización de los servicios de salud: una revisión sistemática sobre los factores relacionados. Cad Saúde Pública 2001;17: 819-32.

Merhy EE. E daí surge o PSF como uma continuidade e um aperfeiçoamento do PACS. Interface 2001; 9:147-149.

Minayo MCS, Sanches O. Quantitativo - Qualitativo: oposição ou complementaridade? Cad Saúde Pública 1993; 9: 239-62.

Morita I. Conselho e conselheiros municipais de saúde: que trama é esta? São Paulo; 2002.[Tese de doutorado - Pontifícia Universidade católica de São Paulo].

Oliveira FA. Antropologia nos serviços de saúde: integralidade, cultura e comunicação. Inferface $2002 ; 6: 63-74$.

OPAS/OMS. Extensão da cobertura dos serviços de saúde mediante o uso das estratégias de assistência primária e participação da comunidade. IV Reunião especial de ministros da saúde da América. Washington, D.C. 26 e 27 de setembro de 1977. 
Organização Mundial da Saúde. CID-10: classificação estatística internacional de doenças e problemas relacionados à saúde. $2^{\text {a }}$ ed. São Paulo: Edusp; 1997. v.3.

Paim JS. A reforma sanitária e os modelos assistenciais. A epidemiologia na organização dos serviços de saúde. In: Anais do $2^{\circ}$ Congresso Brasileiro de Epidemiologia; 1994. Salvador, Brasil. Salvador: COOPMED/ABRASCO; 1994. p.189-98.

Paim JS. Saúde da família: espaço de reflexão e de contra-hegemonia. Interface $2001 ; 9: 143-146$.

Pedrosa JIS. A construção do significado de controle social com conselheiros de saúde no estado do Piauí. Cad Saúde Pública 1997; 13: 741-748.

Pochmann M, Amorim R., organizadores Atlas da exclusão social no Brasil. São Paulo: Cortez, 2003.

Robayo JC. Situaciones de cobertura, niveles de atención y atención primaria. Bol. Of. Sanit. Panam. 1977; 82: 478-90.

Rodrigues Neto E. SUS. Quem são os verdadeiros vilões. Saúde em debate 1996; 50: $11-12$.

Santos BS. A crítica da razão indolente: contra o desperdício da experiência. 3.ed. São Paulo: Cortez; 2001.

Santos NR. O sistema único de saúde: realizando a utopia sem perder a utopia. Saúde em debate 1994; 43: 64-9.

São Paulo. Secretaria de Estado da Saúde. Eixo 1 - Avaliação da Atenção Básica [Online] São Paulo, 2001. Disponível em: <http://www4.saude.sp.gov.br/indica dores/ indicadores.asp.> [27 jan 2003].

SEADE - Fundação Sistema Estadual de análise de dados. Informações dos municípios paulistas. [Online] São Paulo,1999. Disponível em: <http://www. seade.gov.br/> [23 ago. 1999]. 
SEADE - Fundação Sistema Estadual de análise de dados. Informações dos municípios paulistas. [Online] São Paulo, 2001a. Disponível em: $<$ http://www.seade.gov.br/cgi-bin/lingcv98/> [05 nov 2001].

SEADE - Fundação Sistema Estadual de análise de dados. Índice Paulista de Responsabilidade Social. São Paulo: Assembléia Legislativa; 2001 b.

Senna MCM. Eqüidade e política de saúde: algumas reflexões sobre o Programa Saủde da Família. Cad Saúde Pública 2002; 18: 203-211.

Schraiber LB. O médico e seu trabalho: limites da liberdade. 2.ed. São Paulo: Hucitec; 1993.

Silva SF. Municipalização da saúde e poder local. Sujeitos, atores e políticas. São Paulo: Hucitec; 2001.

Souza RR. A regionalização no contexto atual das políticas de saúde. Ciêne Saúde Coletiva $2001 ; 6: 451-455$.

Spink MJP, Medrado B. Produção de sentidos no cotidiano: Uma abordagem teóricometodológica para análise das práticas discursivas. In: Spink MJP, Organizador. Práticas discursivas e produção de sentidos no cotidiano. $2^{\mathrm{a}}$ ed. São Paulo: Cortez; 2000.p.41-61.

Tanaka YO, Nemes MIB, Novaes HMD, Bastos MG, Chester LG, Riedel LF, Rosalen J. Formação de gestores locais de saúde: processos para identificar estratégias de atuação. Rev Saúde Pública 1999; 33: 219-229.

Tanaka YO, Melo C. Avaliação de programas de saúde do adolescente. São Paulo: Edusp; 2001.

Teixeira CF. Promoção e vigilância da saúde no contexto da regionalização da assistência à saúde no SUS. Cad Saúde Pública 2002; 18 (supl): 153-162.

Toledo JR. Causas predominantes de morte refletem as desigualdades no país. Folha de São Paulo, 1998 maio 24; Cotidiano, p.2. 
Travassos C. Eqüidade e o sistema único de saúde: uma contribuição para debate. Cad Saúde Pública 1997; 13:325-330.

Travassos C, Viacava F, Pinheiro R et al. Utilização dos serviços de saúde no Brasil: gênero, características familiares e condição social. Rev Panam Salud Publica $2002 ; 11: 365-373$.

Uchimura KY, Bosi MLM. Qualidade e subjetividade na avaliação de programas e serviços em saúde. Cad Saúde Pública 2002; 18: 1561-69.

Valla VV. Sobre a participação popular: uma questão de perspectiva. Cad Saúde Pública 1998; 14 (supl 2) 7-18.

Verbrugge LM, Wingard DL. Sex differentials in health and mortality. Women Health 1987; 12: 103-145.

Viana ALD, Heimann LS, Lima LD, Oliveira RG, Rodrigues SH. Mudanças no processo de descentralização do sistema de saúde no Brasil. Cad Saúde Pública 2002; 18 (supl): 139-151.

Whitehead M. The concepts and principles of equity and health. Int J Health Serv 1992; $22: 429-445$.

World Bank. Design, content and financing of an essential package of health services. [Online] Washington, 1999. Disponivel em : <http:/www worldbank.org $/ \mathrm{htm} / /$ extrd/hnp/health/hit_sucs/pack/htm.> [19 jun 1999]. 


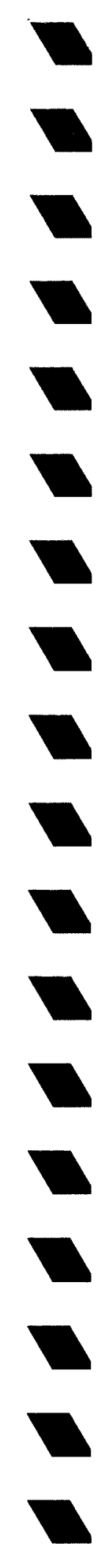

Anexos

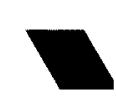

I

I

$\checkmark$ 
7.1 ANEXO 1 - PLANO DIRETOR DE REGIONALIZAÇÃO

$2^{2}$ versão, de acordo com NOAS/SUS 2002

DIREÇÃO REGIONAL DE SAÚDE - BOTUCATU - DIR XI - SUS

ESTUDO PRELIMINAR - PDR (PLANO DIRETOR DE REGIONALIZAÇÃO) $2^{\text {a }}$ Versão

VISANDO HABILITAÇÃO DE ACORDO COM A NOAS/SUS - 2002

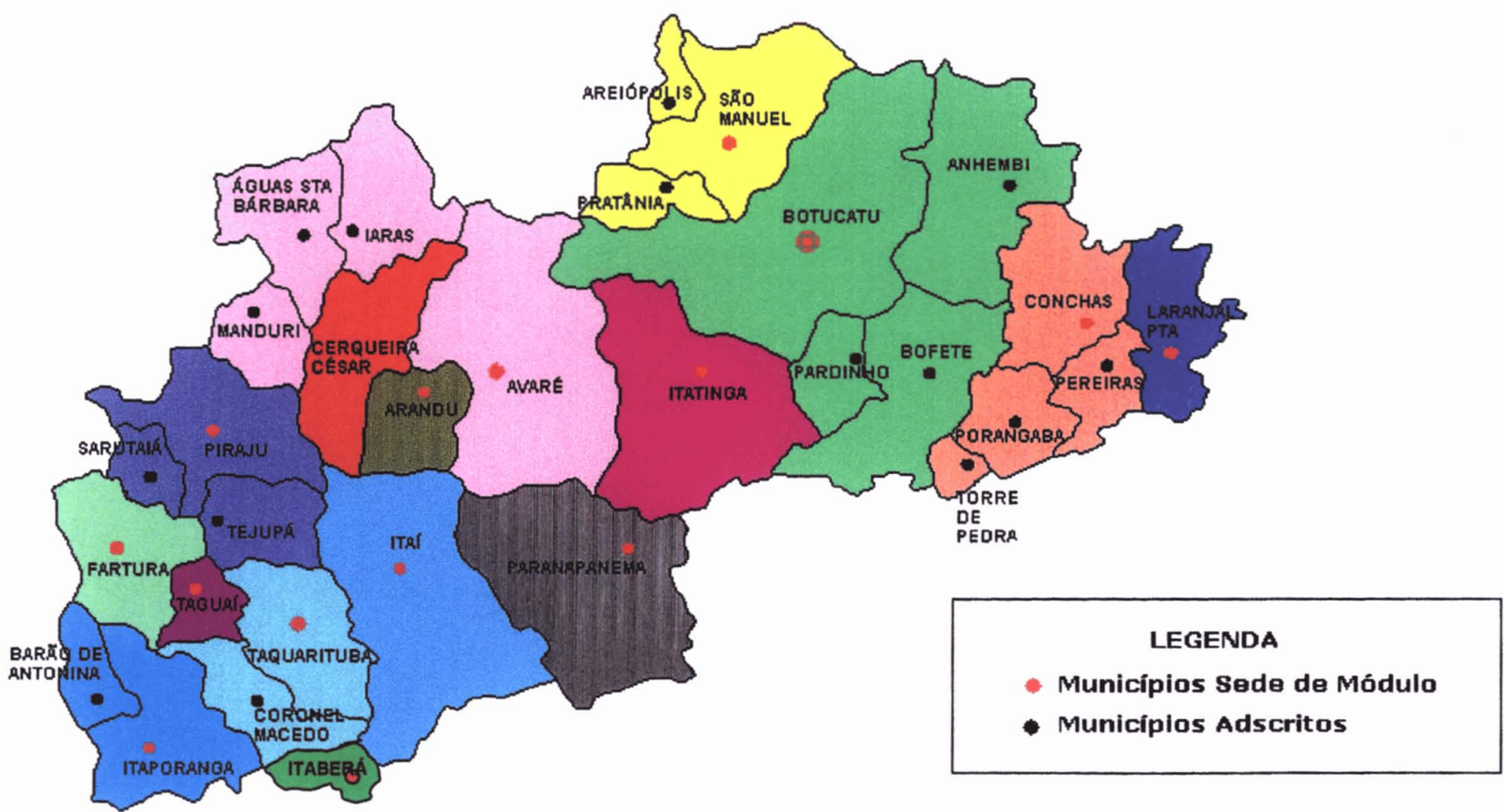

Fonte: DIR XI/SUS 


\section{DIREÇÃO REGIONAL DE SAÚDE - BOTUCATU \\ DIR XI - SUS}

\section{ESTUDO PRELIMINAR - PDR (PLANO DIRETOR DE REGIONALIZACÃO) 2a Versão}

VISANDO HABILITAÇÃO DE ACORDO COM A NOAS/SUS - 2002

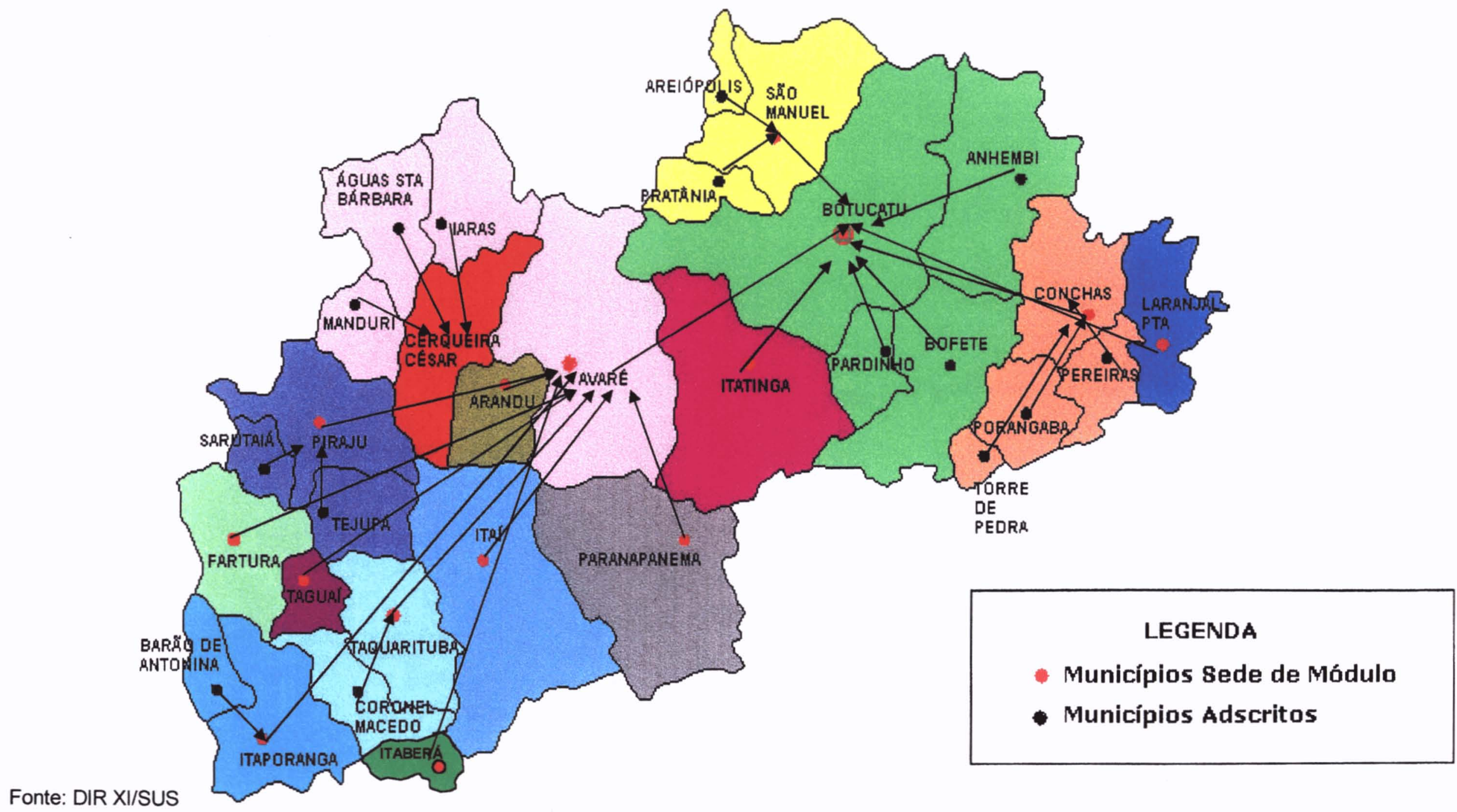


7.3. ANEXO 3 - Mapa Rodoviário da Região da DIR-XI

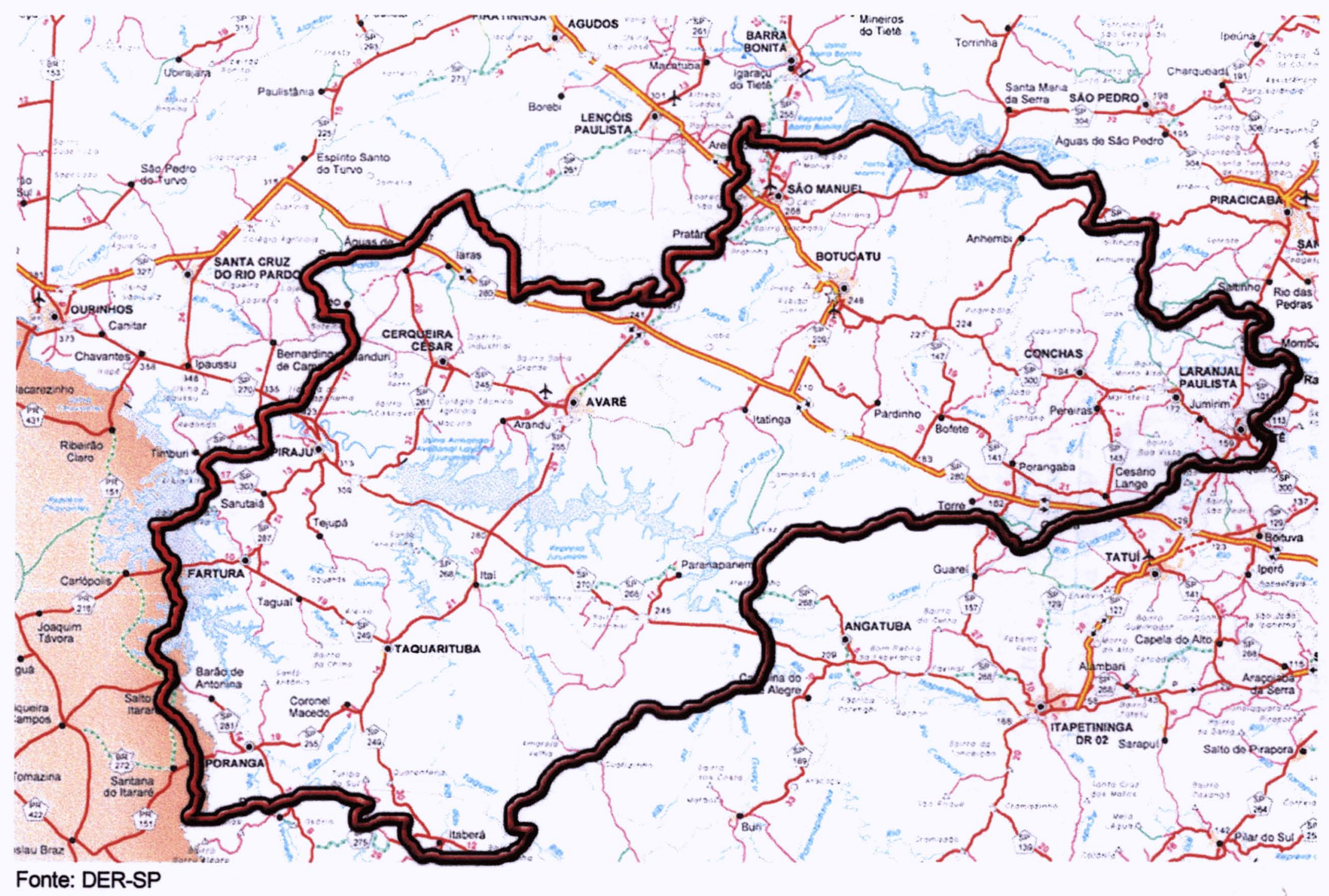




\subsection{Anexo 4 - Aprovação do Comitê de Ética em Pesquisa da Faculdade de Saúde}

Pública - USP e da Faculdade de Medicina da UNESP.

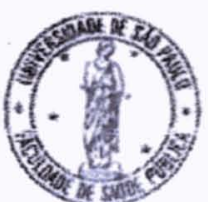

\section{Universidade de São Paulo}

Faculdade de Saúde Pública

COMTTÊ DE ÉTICA FM PESOUISA - COEP

Av. Dr. Amaldo, 715 - CEP 01246-904 - São Paulo - Brasil

Telefones: (55-11) 3066- 7734 - fone/fax (55-11) 3064-7314 e-mail mdgracas@usp.br

Or.

14 de agosto de 2002

Pclo presente, informo que o Comitê de Etica em Pesquisa da Faculdade de Saide Pública da Universidade de São Paulo-COFP analisun a aprovou, em sua $06^{2} / 02$, Sessão Ordinária, realizada em 13.08 .02 de acordo com os requisitos da Resolação CNS/196/96, o Protocolo de Pesquisa n 831. intitulado RTGIONAIIZACÃO DA ASSISTHNCIA A SATIDE ANALISE DE DTMANDA NO SERVIÇO DF URGENCIATMMRGENCIA DF UM HOSPTIAI. UNIVERSITARIO", apresentado pela pesquisadora Heloisa Wey Berti Mendes. Atenciosamente

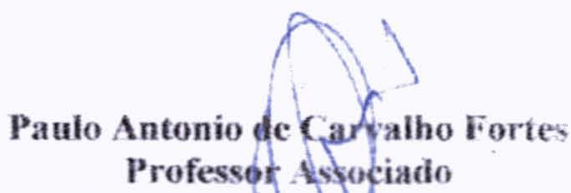

Coordenador do Comitê de Fitican en Pesquisa da FSP-COKP 


\section{Unesp Universidade Estadual Paulista Faculdade de Medicina de Botucatu}

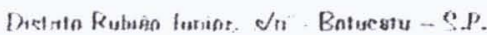

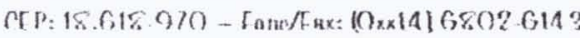

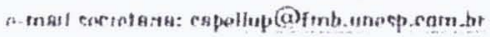

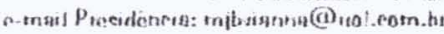

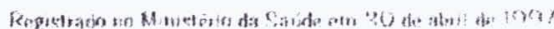

Botucatu 03 de dezembro de 2.001

Of 442/2001-CEP

MJBViasc

Prezada Senhora.

De ordem da Senhora Presidente deste CEP. informo que o Projeto de Pesquisa "Regionalização da assistência à saúde: análise da demanda no Serviço de Urgência/Emergência de um hospital Universitário", de autoria de Vossa Senhoria sob a orientaçäo do Prof. Dr. Eurivaldo Sampaio de Alemida recebeu do relator parecer Favorável aprovado em reuniăo de 03/12/2001

Sendo só para o momento, aproveito o ensejo para renovar os protestos de elevada estima e distinta gonsideraçăo.

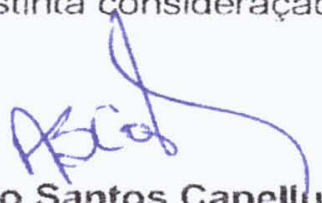

Alberto Santos Capelluppi

Secretário do CEP

llustrissima Senhora

Prof ${ }^{\text {. }}$ Heloisa Wey Berti Mendes

Departamento de Enfermagem

Faculdade de Medicina de Botucatu 
7.5 Anexo 5 - Entrevista estruturada com usuários.

Regionalização da assistência à saúde: análise da demanda no Serviço de urgência- emergência de um Hospital Universitário

Entrevista com usuários

Data: $-1-1--$

Número de ordem

I- Identificação

Nome:

Idade Sexo RG

Ocupação:

Procedência

Estado

Informante: $\square$ próprio paciente

$\square$ responsável grau de parentesco:

II- Avaliação

1- Freqüenta usualmente um serviço de saúde em seu município?

$\square$ Sim

$\square$ Não Por que?

2- Você veio a este serviço de urgência-emergência encaminhado por algum médico ou serviço de saúde?

$\square \operatorname{Sim} \quad$ Quem o encaminhou?

Trouxe alguma carta de encaminhamento? $\square \mathrm{Sim}$

$\square$ Não

Trouxe resultados de exames? $\square$ Sim

$\square$ Não

$\square$ Não

3- Qual o motivo que o levou a procurar um serviço de urgência-emergência?

4- Por que procurou atendimento neste serviço da UNESP?

Condições:

ঢSaúde:

口Econômicas:

$\square$ Situação do município: 
$\square$ Confiabilidade:

口Outros

5- Qual é a doença que o acomete?

Nome:

Descrição:

पNão sabe informar

6- Já procurou outros serviços ou profissionais de saúde para resolver seu problema?

$\square$ Sim. No municipio onde reside. Número de vezes

$\square$ Sim. Em outros municipios da região. Número de vezes

$\square$ Sim. Em outras regiões do estado onde reside. Número de vezes

$\square$ Sim. Em outros estados. Número de vezes

पNão. Por que?

7- Que tipos de serviços já procurou para resolver este seu problema de saúde?

$\square$ Unidade Básica

$\square$ Médico particular

$\square$ Hospital Secundário

$\square$ Hospital Terciário

$\square$ Outros

Quais

8- Há quanto tempo vem tentando resolver esse problema de saúde? meses

$\square$ Não sabe informar

9- Quanto tempo transcorreu desde sua saída do local onde estava até a chegada neste Pronto Socorro? horas

$\square$ Não sabe informar

10- Quais os meios de transportes utilizados para sua vinda até aqui?

$\square$ ônibus

$\square$ veículo emprestado

$\square$ veiculo próprio

$\square$ ambulância

$\square$ UTI móvel

口] Outro Qual 
7.6 Anexo 6 - Questionário aplicado aos médicos do PA e SE

Regionalização da assistência à saúde: análise da demanda no Serviço de urgência- emergência de um Hospital Universitário

Questionário aplicado a médicos do PS

Data: $-1-1--$

Número de ordem

I- Identificação do paciente

Nome:

RG:

II - Identificação do médico que atendeu o paciente

Nome:

III - Informações sobre 0 atendimento

1- Na sua opinião, por que motivo o paciente em questão procurou atendimento neste serviço de urgência-emergência da UNESP?

Condições:

पSaúde:

DEconômicas:

$\square$ Situação do município:

$\square$ Confiabilidade:

口Outros

2- Qual é a sua hipótese diagnóstica para este paciente?

HD

CID

3- Quanto ao tipo de atendimento realizado, considera ter sido:

$\square$ urgência-emergência em nivel terciário.

$\square$ urgência-emergência em nivel secundário.

$\square$ sem necessidade de atendimento em serviço de urgência-emergência e acompanhamento possivel em hospital de nivel secundário.

$\square$ sem necessidade de atendimento em serviço de urgência-emergência ou hospital secundário e acompanhamento possivel no nivel de atenção primária em Unidades Básicas de Saúde.

4- 0 doente veio encaminhado por médico de outro serviço de saúde?

$\checkmark$ Sim. Município onde se originou o encaminhamento: especialidade do médico que encaminhou:

$\square$ Não.

¿Não tenho essa informação 
5- $O$ doente trouxe exames realizados em outros serviços?

$\square$ Não.

$\square$ Sim. Quais:

Os exames foram úteis?

$\square$ Sim. Por que?

$\square$ Não. Por que?

Houve neçessidade de repetição dos exames?

$\square$ Sim. Por que?

○ Não.

IV - Informações sobre a conduta médica tomada para este paciente

Dispensado sem atendimento.

$\square$ Dispensado após atendimento, sem encaminhamento ao serviço de origem.

$\square$ Atendido e dispensado, com encaminhamento para outros hospitais da região, dando informações, por escrito, sobre o atendimento realizado.

$\square$ Atendido e dispensado, com encaminhamento para Unidades Básicas do município, dando informações, por escrito, sobre o atendimento realizado.

$\square$ Atendido e orientado para aguardar consulta com médicos especialistas do próprio Serviço de urgência-emergência.

[] Atendido e encaminhado para agendamento de consulta na triagem ou ambulatório de especialidades do HC - FMB.

$\square$ Atendido e encaminhado para agendamento de consulta no NGA de Botucatu.

$\square$ Atendido e encaminhado ao Setor de Emergência do PS.

$\square$ Atendido e encaminhado para internação na enfermaria do PS.

$\square$ Atendido e encaminhado para internação nas enfermarias do HC - FMB.

$\square$ Outra(s) condutas. Quais 
7.7 Anexo 7 - Roteiro de entrevista com gestor regional, gestores municipais e chefia do Pronto Socorro do HC-FMB.

1. Em estudo realizado no Pronto Atendimento e Setor de Emergência da UNESP verificamos uma importante demanda espontânea de pacientes dos municípios que compõem a DIR XI que poderia ter seu problema de saúde resolvido em uma Unidade Básica ou em um Hospital Secundário, sem necessidade desse deslocamento para a UNESP. O que você tem a dizer sobre isso? Que implicações isso pode ter?

2. Nesse mesmo estudo, os usuários entrevistados fazem muitas referências à confiança que depositam no atendimento prestado pela UNESP. A que você atribui isto?

3. Foi também observada grande demanda de solicitações à Central de Regulação de Vagas com as justificativas de falta de médicos e de materiais ou equipamentos para o atendimento de doentes no próprio município. O que você pode dizer sobre isto? Além da falta de recursos, que outros problemas estão levando à procura dos serviços da UNESP?

4. Gostaria que você falasse um pouco sobre o que vem achando das condutas tomadas pela Central de Regulação de Vagas no atendimento às solicitações dos municípios para os casos de urgência/emergência.

5. O que você acha da quota de vagas para a Triagem de Especialidades que os municípios possuem na UNESP e como está se dando esse relacionamento Município/ Triagem? 
6. Eu gostaria que você falasse um pouco sobre algumas características da assistência à saúde em seu município. Pode ser?

Então, com relação á eqüidade da atenção, como está?

E quanto à integralidade da assistência?

E a qualidade da assistência?

Como está o controle social?

E a regionalização e hierarquização do atendimento?

7. Como tem sido o acesso das pessoas aos serviços de saúde da região, nos níveis secundário e terciário?

8. Você conhece a NOAS SUS 2001 e 2002, não é? Fale-me um pouco sobre isso, sobre o que você acha.

9. De tudo o que você acaba de me dizer, o que você pode concluir sobre a assistência à saúde prestada pelo seu município?

10. O que você acha que poderia ser feito para fortalecer e ampliar as responsabilidades dos municípios na atenção básica? 
7.8 Anexo 8 - Termos de Consentimento Livre e Esclarecido

Anexo 7.8.1 - Termo de Consentimento Livre e Esclarecido - Usuários

\section{TERMO DE CONSENTIMENTO LIVRE E ESCLARECIDO PARA PARTICIPAÇÃO EM TRABALHO CIENTÍFICO \\ - Usuários -}

Projeto de Pesquisa: "Regionalização da assistência à saúde: análise da demanda no Serviço de Urgência/Emergência de um Hospital Universitário".

O objetivo da presente pesquisa é o de estudar o atendimento à saúde na região de Botucatu, analisando a demanda de doentes no Pronto Socorro do Hospital das Clínicas de Botucatu - UNESP.

Solicito seu consentimento para participar de entrevista, respondendo perguntas sobre seus dados pessoais, ou de seu dependente, local onde reside, motivos da procura do Pronto Socorro da UNESP e atendimentos anteriores em outros serviços.

Tendo sido satisfatoriamente informado sobre a pesquisa Regionalização da assistência à saúde: análise da demanda no Serviço de Urgência-Emergência de um Hospital Universitário, sob responsabilidade da Professora Assistente do Departamento de Enfermagem da Faculdade de Medicina de Botucatu - UNESP Heloisa Wey Berti Mendes, aluna do Curso de Pós-graduação, nivel doutorado, da Faculdade de Saúde Pública - USP, orientada pelo Professor Doutor Eurivaldo Sampaio de Almeida, declaro que concordo participar da mesma, respondendo às perguntas apresentadas em entrevista.

Estou ciente de que as informações serão utilizadas exclusivamente pela pesquisadora, que manterá sigilo sobre minha identidade; que a mesma está disponível para responder a quaisquer perguntas e que poderei retirar esse consentimento a qualquer tempo. Esclarecimentos adicionais poderão ser obtidos com a pesquisadora pelos telefones: 01468221812 e 01468235264 .

de de 2002 
Anexo 7. 8.2 - Termo de Consentimento Livre e Esclarecido - Usuários

\section{TERMO DE CONSENTIMENTO LIVRE E ESCLARECIDO PARA PARTICIPAÇÃO EM TRABALHO CIENTÍFICO \\ - Usuários -}

Projeto de Pesquisa: "Regionalização da assistência à saúde: análise da demanda no Serviço de Urgência/Emergência de um Hospital Universitário".

O objetivo da presente pesquisa é o de estudar o atendimento à saúde na região de Botucatu, analisando a demanda de doentes no Pronto Socorro do Hospital das Clínicas de Botucatu - UNESP.

Solicito seu consentimento para participar de entrevista gravada em fita Cassete, respondendo perguntas sobre motivos da procura do Pronto Socorro da UNESP e atendimentos anteriores em outros serviços.

Tendo sido satisfatoriamente informado sobre a pesquisa Regionalização da assistência à saúde: análise da demanda no Serviço de Urgência-Emergência de um Hospital Universitário, sob responsabilidade da Professora Assistente do Departamento de Enfermagem da Faculdade de Medicina de Botucatu - UNESP Heloisa Wey Berti Mendes, aluna do Curso de Pós-graduação, nivel doutorado, da Faculdade de Saúde Pública - USP, orientada pelo Professor Doutor Eurivaldo Sampaio de Almeida, declaro que concordo participar da mesma, respondendo as perguntas apresentadas em entrevista com o uso de gravador.

Estou ciente de que as informações serão utilizadas exclusivamente pela pesquisadora, que manterá sigilo sobre minha identidade; que a mesma está disponível para responder a quaisquer perguntas e que poderei retirar esse consentimento a qualquer tempo. Esclarecimentos adicionais poderão ser obtidos com a pesquisadora pelos telefones: 01468221812 e 01468235264 . de de 2002 
Anexo 7.8. 3 - Termo de Consentimento Livre e Esclarecido - Médicos do Serviço de Urgência/Emergência

\section{TERMO DE CONSENTIMENTO LIVRE E ESCLARECIDO PARA PARTICIPAÇÃO EM TRABALHO CIENTÍFICO \\ - Médicos do PA e SE -}

Projeto de Pesquisa: "Regionalização da assistência à saúde: análise da demanda no Serviço de Urgência-Emergência de um Hospital Universitário".

O objetivo da presente pesquisa é o de estudar o processo de regionalização do atendimento na DIR XI a partir de análise da demanda de doentes ao Pronto Socorro do Hospital das Clínicas de Botucatu - UNESP.

Solicito seu consentimento para participar de entrevista, respondendo perguntas sobre caracteristicas do atendimento prestado ao paciente participante deste estudo, no Pronto Socorro da UNESP, quanto a hipótese diagnóstica, tipo de atendimento (alta, média ou baixa complexidade) e conduta adotada.

Tendo sido satisfatoriamente informado sobre a pesquisa "Regionalização da assistência à saúde: análise da demanda no Serviço de Urgência-Emergência de um Hospital Universitário", sob responsabilidade da Professora Assistente do Departamento de Enfermagem da Faculdade de Medicina de Botucatu - UNESP Heloisa Wey Berti Mendes, aluna do Curso de Pósgraduação, nivel doutorado, da Faculdade de Saúde Pública - USP, orientada pelo Professor Doutor Eurivaldo Sampaio de Almeida, declaro que concordo participar da mesma, respondendo as perguntas apresentadas em entrevista.

Estou ciente de que as informações serão utilizadas exclusivamente pela pesquisadora, preservando-se a confidencialidade; que a mesma está disponivel para responder a quaisquer perguntas e que poderei retirar este consentimento a qualquer tempo. Esclarecimentos adicionais poderão ser obtidos com a pesquisadora pelos telefones: 01468221812 e 01468235264 .

de de 2002 
Anexo 7.8.4 - Termo de Consentimento Livre e Esclarecido - Gestores

\section{TERMO DE CONSENTIMENTO LIVRE E ESCLARECIDO PARA PARTICIPAÇÃO EM TRABALHO CIENTÍFICO - Gestores-}

Projeto de Pesquisa: Regionalização da assistência à saúde: análise da demanda no Serviço de Urgência-Emergência de um Hospital Universitário

O objetivo da presente pesquisa é o de estudar o processo de regionalização do atendimento na DIR XI a partir de análise da demanda de doentes ao Pronto Socorro do Hospital das Clínicas de Botucatu - UNESP.

Solicito seu consentimento para participar de entrevista e permitir que ela seja gravada $\mathrm{em}$ fita K7, respondendo perguntas sobre aspectos do atendimento prestado na região e no seu município, bem como sua visão do processo de regionalização na DIR XI.

Tendo sido satisfatoriamente informado sobre a pesquisa "Regionalização da assistência à saúde: análise da demanda no Serviço de Urgência-Emergência de um Hospital Universitário", sob responsabilidade da Professora Assistente do Departamento de Enfermagem da Faculdade de Medicina de Botucatu - UNESP Heloisa Wey Berti Mendes, aluna do Curso de Pósgraduação, nível doutorado, da Faculdade de Saúde Pública - USP, orientada pelo Professor Doutor Eurivaldo Sampaio de Almeida, declaro que concordo participar da mesma, respondendo as perguntas apresentadas em entrevista.

Estou ciente de que as informações serão utilizadas exclusivamente pela pesquisadora, preservando-se a confidencialidade; que a mesma está disponível para responder a quaisquer perguntas e que poderei retirar este consentimento a qualquer tempo. Esclarecimentos adicionais poderão ser obtidos com a pesquisadora pelos telefones: 01468221812 e 01468235264 .

de de 2002 
7.9 Anexo 9 - Roteiro de entrevista aberta com usuários do PA e SE

Roteiro de entrevista com usuários - PA e PS

1- Você costuma freqüentar algum serviço de saúde?

2- Por que você decidiu vir a este serviço de urgência-emergência? Além do problema de saúde, por que escolheu este serviço?

3- O que você veio fazer aqui neste serviço?

4- Você já procurou outros serviços ou profissionais de saúde para resolver este seu problema?

5- Qual o meio de transporte que utilizou? Quanto tempo levou desde a sua saída do local onde estava até sua chegada neste pronto Socorro? Demorou muito? 